Stable Isotope Geochemistry of Nitrogen In Marine Particulates

by

Susan M. Libes

B.A., Douglass College

(1977)

SUBMITTED IN PARTIAL FULFILLMENT

OF THE REQUIREMENTS FOR THE

DEGREE OF

DOCTOR OF PHILOSOPHY

at the

MASSACHUSETTS INSTITUTE OF TECHNOLOGY

and the

WOODS HOLE OCEANOGRAPHIC INSTITUTION

January, 1983

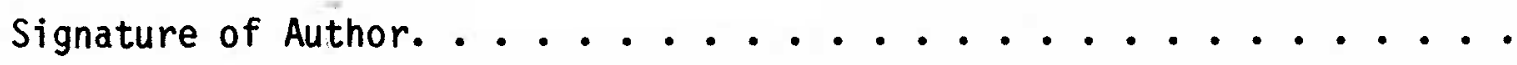

Department of Earth and $\mathrm{P} 1$ anetary Sciences,

Massachusetts Institute of Technology and the Joint Program in 0ceanography, Massachusetts Institute of Technology/ Woods Hole Oceanographic Institution, January, 1983.

Certified by.

Werner G. Deuser, Thes is Supervisor.

Accepted by. ....

Chairman, Joint Committee for Chemical Oceanography, Massachusetts Institute of Technology/ Woods Hole Oceanographic Institution. 


\section{STABLE ISOTOPE GEOCHEMISTRY OF NITROGEN IN MARINE PARTICULATES}

by

Susan M. Libes

Submitted to the Joint Committee of Chemical Oceanography, Massachusetts Institute of Technology and Woods Hole oceanographic Institution on December 30, 1982 in partial fulfillment of the requirements for the Degree of Doctor of Philosophy

\section{Abstract}

Isotope studies of nitrogen and carbon were undertaken to investigate the fate of particulate organic matter (POM) during its residence in the water column and after deposition on the seafloor. The processes focused on were water-column transformations and sedimentary diagenesis. Sampling sites were chosen to provide POM subject to different specific mineralization processes (nitrification, denitrification, and sulfate reduction), different lengths of water column (duration of the mineralization process), and differences in the size of the organic-matter flux. The $\delta 15 \mathrm{~N}$ and $\delta 13 \mathrm{C}$ of plankton, POM, and sediments from several oceanic sites were related to biological and hydrographic processes identified from nutrient, temperature, and salinity profiles. This was done to determine what effect these processes have on the $\delta 15 \mathrm{~N}$ of POM. Four stations were studied in the upwelling area off the coast of Peru and one station was studied in the Gulf of Maine.

Important factors controlling the $\delta 15 \mathrm{~N}$ of plankton appear to be the concentration and $\delta 15 \mathrm{~N}$ of nitrate in the surface waters, and the relative zooplankton and phytoplankton abundances. Plankton from the Peru Upwelling Area are enriched in $15 \mathrm{~N}$ as compared to plankton from other parts of the world's oceans where denitrification is absent. This enrichment may be due to the assimilation of $15 \mathrm{~N}$-enriched nitrate, produced by the selective reduction of $14 \mathrm{~N}$ during denitrification. Zooplankton are 3 to $40 / 00$ enriched in $15 \mathrm{~N}$ as compared with phy toplankton. Production of $14 \mathrm{~N}$-enriched fecal pellets is suggested as a mechanism for this trophic enrichment.

In the surface waters, the $\delta 15 \mathrm{~N}$ of POM is similar to that of plankton. In the Peru Upwelling Area, the $\delta 15 \mathrm{~N}$ of POM from the oxygen-deficient waters decreases with increasing depth. In the Gulf of Maine, below the euphotic zone in the oxic deep waters, the $\delta 15 \mathrm{~N}$ of POM increases with increasing depth. The difference in isotopic alteration may be due to the effect of different redox conditions on the mechanism and sequence by which specific organic nitrogen compounds, variably enriched in $15 \mathrm{~N}$, undergo degradation. Furthermore, bacterial growth on nitrogen-poor particles in the deep waters of the Peru Upwelling Area may 
contribute to the 1 ow $\delta 15 \mathrm{~N}$ of POM.

In contrast to the 1 arge range in $\delta 15 \mathrm{~N}(-2$ to $+170 / 00)$ of the POM, the range of $\delta 15 \mathrm{~N}$ in the sediments is small $(+5$ to $+90 / 00)$. Within a core, the average variation in $\delta 15 \mathrm{~N}$ was only $1.80 \% 00$. Temporal variability in the $\delta 15 \mathrm{~N}$ of sedimenting POM and benthic activity appear to be important in determining the $\delta 15 \mathrm{~N}$ of the sediments. The large changes in POM concentration and isotope content at the sediment/water interface as compared with the more constant values found down-core, suggest that processes occuring at the sediment/water interface are critical, although bioturbation may also be important in determining the $\delta 15 \mathrm{~N}$ of oxic sediments. If diagenesis causes a significant loss of organic matter, profiles of organic carbon and nitrogen contents should show decreases with increasing depth and $\mathrm{C} / \mathrm{N}$ ratios should increase with increasing depth (Reimers, 1981). Since none of the sedimentary profiles exhibited such trends, it is concluded that diagenesis was insufficient to erase the percent carbon, nitrogen and $\mathrm{C} / \mathrm{N}$ ratio signatures generated by the POM fiux and al terations at the sediment/water interface. Temporal variability in the $\delta 15 \mathrm{~N}$ of bottom-water POM may be caused by changes in deep-water currents which transport POM horizontally and to changes in bacterial and possibly other biological activity in the water column.

This thesis work suggests that $\delta^{15} \mathrm{~N}$ may be a useful tool in studying the geochemistry of POM in the marine environment. In addition, this research has shown that interpretation of the sedimentary $15 \mathrm{~N}$ record must include consideration of isotopic alteration associated with bacterial remineralization of POM and benthic activity.

Thesis Supervisor: Dr. W.G. Deuser

Title:

Senior Scientist Chemistry Department Woods Hole Oceanographic Insitution Woods Hole, Massachusetts 


\section{ACKNOWLEDGEMENTS}

This thesis represents the work of multitudes. Of special importance were the efforts of my advisor, $W$. Deuser, who not only made me into an isotope geochemist, but put up with a seemingly endless number of mercury spills and glassware crises. Second in line is Edith Ross, who had to tolerate my daily presence in the $1 \mathrm{ab}$. I al so thank my other thesis advisors, B. Benson, E. Boyle, C. Lee, and C. Taylor, who spent vast amounts of time traveling to $\mathrm{Cl}$ ark Building to attend committee meetings and reading endless drafts of this thesis.

Special thanks go to W. Dickinson, Z. Mlodzinska, T. Loder, and $B$. Brockhurst for nutrient concentration measuring, to $\mathrm{P}$. Clarner for $\mathrm{CHN}$ analyses, to R. Anderson for assembling various glass-lines, and to P. Sachs for putting together and deploying the in-situ pumps. Alan Fleer was instrumental in organizing sea-going equipment and teaching me how to use it. M. Bothner, P. Brewer, and the Biology Department lent a lot of equipment for long periods of time. At sea, E. Franks, R. Chandler, D. Shafer, B. Belastock and the crews of the R/V Atlantis II and Oceanus made sample collection possible. M. Bacon, F. Sayles, and R. Von Herzen graciously donated ship time. D. Repeta and P. Gschwend provided samples from Station SEAREX and $J$. Cheney identified plankton.

Various other ${ }^{15} \mathrm{~N}$ geochemists provided valuable assistance in intercalibrating and getting me going. They are: S. Macko, M. DeNiro, R. Sweeney, and L. Pandolfi. The support services of the Machine Shop, Carpentry Shop, Graphics Department, Shipping and Receiving, and the Education Office are also gratefulty acknowledged. Funds for this research were provided by the Massachusetts Institute of Technology/ Woods Hole Oceanographic Institution Joint Program in Oceanography, the National Science Foundation under Grant No. OCE-8024442, and the Andrew W. Mellon Foundation through the Center for Coastal Research of the Woods Hole Oceanographic Institution. 
The emotional support and fruitful discussions with R. Anderson, H. deBaar, A. McNichol, D. Repeta, W. Martin, M. Delaney, K. Von Damm, J. Jasper, A. Spivak, E. Druffel, P. Kahn, S. Barnes, and P. Forte were indespensible. Finally without S. Smith and my parents I would have given up long ago. 
TABLE OF CONTENTS

Abstract............................. . .

Acknowledgements. . . . . . . . . . . . . . . . . . 4

Table of Contents. . . . . . . . . . . . . . 6

List of Figures....................... 9

List of Tables. . . . . . . . . . . . . . . . 13

Chapter I: Introduction. . . . . . . . . . . . . . . . 14

General Introduction. . . . . . . . . . . . . . 14

Statement of Thesis Research............... 16

Nitrogen Biogeochemistry . . . . . . . . . . . . . . 17

Dissolved Nitrogen. . . . . . . . . . . . . . . 17

Particulate Organic Nitrogen. . . . . . . . . . . . . 22

Nitrogen and Carbon Isotopes as Tracers of Biologically Mediated

Reactions in the Marine Environment. . . . . . 25

Nitrogen-Isotope Geochemistry. . . . . . . . . . . . . 25

Theory and Laboratory Studies. . . . . . . . . . . . . 25

Field Work. . . . . . . . . . . . . . . . 31

Carbon-Isotope Geochemistry. . . . . . . . . . . . . 42

Stable Isotope Geochemistry and POM Cycling. . . . . . . . . . . 45

Chapter II: Sampling and Analytical Methods. . . . . . . . . . . .47

Sampling. . . . . . . . . . . . . . . . . . 47

Sediment. . . . . . . . . ............ 47

Plankton. . . . . . . . . . . . . . . 47

Particulate Matter. ................. 48

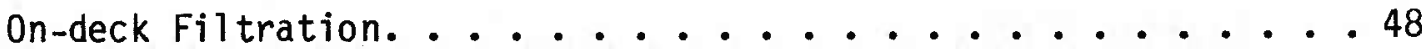

In-situ Large Volume Pumps. . . . . . . . . . . . 52 
Sediment Traps. . . . . . . . . . . . . . . 55 Hy drographic and Other Standard Measurements. . . . . . . . . 55

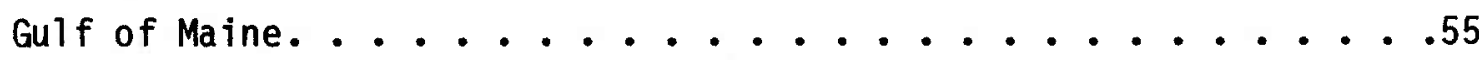

Peru Upwelling Area. . . . . . . . . . . . . . . . . . 55

Isotope Measurements. . . . . . . . . . . . . . 56

Sample Preparation. . . . . . . . . . . . . . . 56

Analysis of Carbon and Nitrogen Isotopes. . . . . . . . . 56

Summary. . . . . . . . . . . . . . . . . . . 82

Chapter III: Peru Upwelling Area. . . . . . . . . . . . 86

Introduction. . . . . . . . . . . . . . . . 86

Station Locations. . . . . . . . . . . . . . . . . 91

Station SEAREX. ..................... 91

Station A. . . . . . . . . . . . . . . . 100

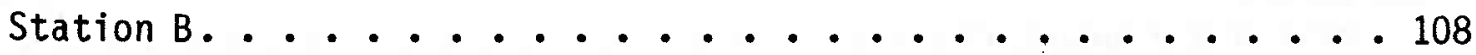

Station C........................ 115

Plankton. . . . . . . . . . . . . . . . . . . 122

Species Composition and Isotope Analyses. . . . . . . . . . 122

Discussion. . . . . . . . . . . . . . . . . . 126

Nitrogen Isotopes. . . . . . . . . . . . . . 126

Carbon Isotopes. . . . . . . . . . . . . . . 137

Particulate Organic Matter. . . . . . . . . . . . . . 138

Sampling and Analysis. . . . . . . . . . . . . . 138

Isotope Analyses of POM. . . . . . . . . . . . . . . 142

Station SEAREX. . . . . . . . . . . . . . . . 142

Station A. . . . . . . . . . . . . . . . 148

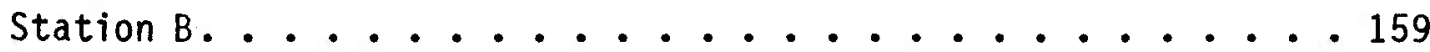

Station C. . . . . . . . . . . . . . . 169

Discussion of POM Results . . . . . . . . . . . . . . 179

Sediments. . . . . . . . . . . . . . . . 189

General Description. . . . . . . . . . . . . . 189

Results of Isotopic Analyses of Sediment . . . . . . . . . 189

Station SEAREX. . . . . . . . . . . . . . . 189

Station A. . . . . . . . . . . . . . . . 197 
Station B and Two Other Shelf-Break Stations. . . . . . . 197

Station C. . . . . . . . . . . . . . . . 206

Discussion of Sediment Results. . . . . . . . . . . . 206

Chapter IV: Gulf of Maine. . . . . . . . . . . . . 219 Introduction. . . . . . . . . . . . . . . . . 219 Station Location, Hydrography, and Nutrient Concentrations. . . . 220 Results and Discussion of Isotopic Analyses of Plankton. . . . . 223 Results ana Discussion of Isotopic Analyses of POM. . . . . . . 231 Results and Discussion of Isotopic Analyses of Sediment. . . . . 243 Conclusions and Summary................ . . . 249

Chapter V: Summary and Conclusions. . . . . . . . . . . . 251 General Discussion. . . . . . . . . . . . . . . 251

Plankton. . . . . . . . . . . . . . . . . 251

Particulate Organic Matter. . . . . . . . . . . . . 256

Sediments. . . . . . . . . . . . . . . 259

Future Work. . . . . . . . . . . . . . . . 265

Bibliography. . . . . . . . . . . . . . . . . . . . 68

Appendix I: Double-Tube Combustion Method. . . . . . . . . 280

Appendix II: Distilled-Water Rinsing Experiment. . . . . . . . . 285

Biographical Note. . . . . . . . . . . . . . . . 288 


\section{LIST OF FIGURES}

Figure

$\underline{\text { Page }}$

1-1. Nitrogen Cycle, from Sweeney et al. (1978) . . . . . . . 18

1-2. The $\delta 15 \mathrm{~N}_{\mathrm{p}}$ Predicted from Fractionation Factors in Table $1-1$. . 29

1-3. Distribution of $\delta^{15} \mathrm{~N}$, from Macko (1981) . . . . . . . . . 32

1-4. $\delta^{15} \mathrm{~N}$ of Nitrate, from Liu (1979). . . . . . . . . . 34

1-5. Nitrogen and Carbon Isotope Ratios of Sedimentary Organic

Matter from Coastal California, from Peters et a1. (1978). . . .36

1-6. $\delta 15 \mathrm{~N}$ of Particulate Organic Nitrogen in the Northeastern

Indian Ocean, from Saino and Hattori (1980)..........40

2-1. Particulate-Matter Filtration Apparatus. . . . . . . . . .49

2-2. In-Situ Pump Apparatus. . . . . . . . . . . . 53

2-3. Combustion Tubes. . . . . . . . . . . . . 59

2-4. "Long-Neck" Combustion Tubes. . . . . . . . . . . . 62

2-5. High-Vacuum Separation Line. . . . . . . . . . . . . 65

2-6. Nitrogen Gas Sample Tube. . . . . . . . . . . . 70

2-7. Inlet System of the Mass Spectrometer. . . . . . . . . . 73

2-8. $\delta^{15} \mathrm{~N}_{\mathrm{N}}$ of Tank $\mathrm{N}_{2}$ used as Working Standard. ......... 76

3-1. The Distribution of Primary Productivity in the Peru Upwelling Area, from Zuta and Guillen (1970). . . . . . 87

3-2. Station Locations in the Peru Upwelling Area. . . . . . . . 92

3-3. Peru Upwelling Area Station SEAREX: Phaeophytin, Chlorophyll a, Phosphate, Silicate and Oxygen Concentrations, from

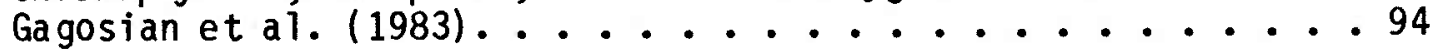

3-4. Peru Upwelling Area Station SEAREX: Nitrate, Nitrite, and Ammonia Concentrations, from Gagosian et a1. (1983). . . . . .96

3-5. Peru Upwelling Area Station SEAREX: Temperature, Salinity, and Density, from Gagosian et al. (1983). . . . . . . . 98 
Figure

3-6. Peru Upwelling Area Station A: Dissolved Organic Nitrogen, Total Dissolved Nitrogen, Phosphate, Silicate, and Oxygen

Concentrations. . . . . . . . . . . . . . 101

3-7. Peru Upwelling Area Station A: Nitrate, Nitrite, and

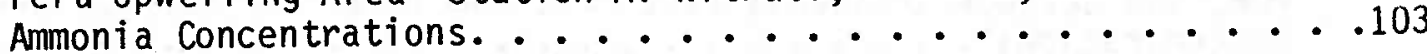

3-8. Peru Upwelling Area Station A: Temperature, Salinity,

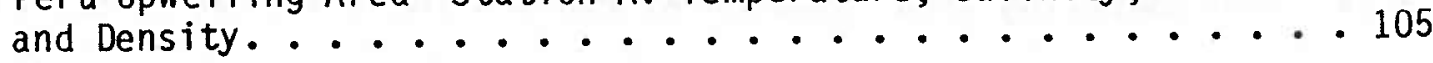

3-9. Peru Upwelling Area Station B: Dissolved Organic Nitrogen, Total Dissolved Nitrogen, Phosphate, Silicate, and Oxygen Concentrations. . . . . . . . . . . . . . . . . . 09

3-10. Peru Upwelling Area Station B: Nitrate, Nitrite, and Ammonia Concentrations. . . . . . . . . . . . . 111

3-11. Peru Upwelling Area Station B: Temperature, Salinity, and Density..................... 113

3-12. Peru Upwelling Area Station C: Dissolved Organic Nitrogen, Total Di ssolved Nitrogen, Phosphate, Silicate, and Oxygen

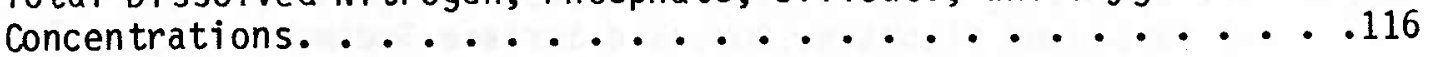

3-13. Peru Upwelling Area Station C: Nitrate, Nitrite, and Ammonia Concentrations. . . . . . . . . . . 118

3-14. Peru Upwelling Area Station C: Temperature, Salinity, and Density....................... 120

3-15. The Geographic Distribution of $\delta 15 \mathrm{~N}$ in Marine Plankton. . . . 127 3-16. The Geographic Distribution of $\delta 15 \mathrm{~N}$ in Marine Phytoplankton. . . 129 3-17. The Geographic Distribution of $\delta 15 \mathrm{~N}$ in Marine Zooplankton. . . 131

3-18. $\delta 15 \mathrm{~N}$ of Plankton Size Fractions from the Peru Upwelling Area. • . 135

3-19. ${ }^{13} \mathrm{C}$ of Plankton Size Fractions from the Peru Upwelling Area. . . 139

3-20. Peru Upwelling Area Station SEAREX: $\delta^{15} \mathrm{~N}$ and $\delta^{13} \mathrm{C}$ of Plankton, POM Collected in Sediment Traps, and Surface Sediments

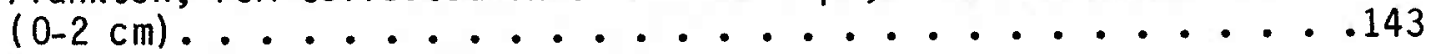

3-21. Peru Upwelling Area Station SEAREX: C/N Ratio, Percent Organic Carbon and Ni trogen of Plankton, POM Collected in Sediment Traps,

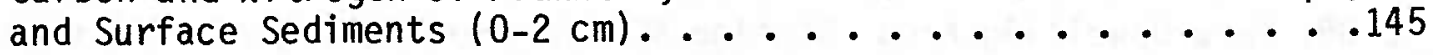


Figure

Page

3-22. Peru Upwelling Area Station $\mathrm{A}: \delta^{15 \mathrm{~N}}$ and $\delta^{13 \mathrm{C}}$ of Plankton, POM, and Surface Sediments $(0-2 \mathrm{~cm}) . \ldots 149$

3-23. Peru Upwelling Area Station A: C/N Ratio of Plankton, POM, and Surface Sediments $(0-2 \mathrm{~cm})$, and Total Particulate Matter

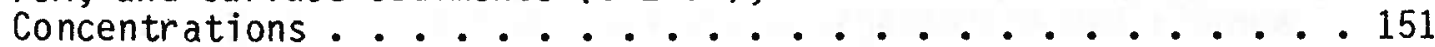

3-24. Peru Upwelling Area Station A: PON and POC Concentrations. • . 153

3-25. Peru Upwelling Area Station A: Percent Organic Nitrogen and Carbon of P1ankton, POM, and Surface Sediments $(0-2 \mathrm{~cm}) \ldots 155$

3-26. Peru Upwelling Area Station $\mathrm{B}: \delta^{15 \mathrm{~N}}$ and $\delta^{13} \mathrm{C}$ of $\mathrm{Plankton}$, POM, and Surface Sediments $(0-2 \mathrm{~cm}) . \ldots 160$

3-27. Peru Upwelling Area Station B: C/N Ratio of Plankton, POM, and Surface Sediments $(0-2 \mathrm{~cm})$ and Total Particulate Matter

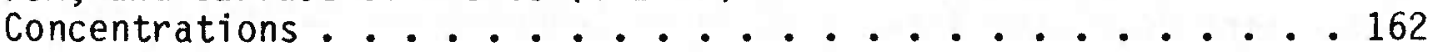

3-28. Peru Upwelling Area Station B: PON and POC Concentrations. . .164

3-29. Peru Upwelling Area Station B: Percent Organic Nitrogen and Carbon of Plankton, POM, and Surface Sediments $(0-2 \mathrm{~cm}) . .166$

3-30. Peru upwelling Area Station $\mathrm{C}: \delta 15 \mathrm{~N}$ and $\delta 13 \mathrm{C}$ of $\mathrm{Pl}$ ankton, POM, and Surface Sediments $(0-2 \mathrm{~cm}) . \ldots 170$

3-31. Peru Upwelling Area Station C: C/N Ratio of Plankton, POM, and Surface Sediments $(0-2 \mathrm{~cm})$, and Total Particulate Matter Concentrations .......................... 172

3-32. Peru Upwelling Area Station C: PON and POC Concentrations. . . 174

3-33. Peru Upwelling Area Station C: Percent Organic Nitrogen and Carbon of Plankton, POM, and Surface Sediments $(0-2 \mathrm{~cm}) \ldots 176$

3-34. Peru Upwelling Area: $\delta 15 \mathrm{~N}$ of POM versus Oxygen Concentrations. - 181

3-35. $\delta 15 \mathrm{~N}$ of Decomposing POM versus Incubation Time (Wada, 1980). . 186

3-36. The Distribution of Percent Organic Carbon in the Sediments off the Coast of Peru, from Reimers (1981). . . . . . 190

3-37. Peru Upwelling Area Station SEAREX: $\delta 15 \mathrm{~N}$ and $\delta 13 \mathrm{C}$ of the

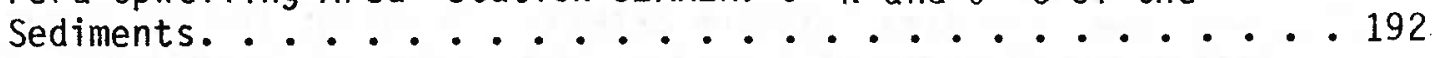

3-38. Peru Upwelling Area Station SEAREX: Percent Organic Nitrogen and Carbon, and $\mathrm{C} / \mathrm{N}$ Ratio in the Sediments. ................. 
Figure

Page

3-39. Peru Upwelling Area Station $A: \delta 15 \mathrm{~N}$ and $\delta 13 \mathrm{C}$ of the Sediments. . . . . . . . . . . . . 198

3-40. Peru Upwelling Area Station A: Percent Organic Nitrogen and Carbon, and C/N Ratio in the Sediments. .........200

3-41. Peru Upwelling Area Station $\mathrm{B}: \delta^{15 \mathrm{~N}}, \delta^{13 \mathrm{C}}$, Percent Organic Nitrogen and Carbon, and C/N Ratio in the Sediments. . 203

3-42. Peru Upwelling Area Station C: $\delta 15 \mathrm{~N}, \delta 13 \mathrm{C}$, Percent Organic Nitrogen and Carbon, and $\mathrm{C} / \mathrm{N}$ Ratio in the Sediments. . 207

3-43. $\delta 15 N$ versus Percent Organic Nitrogen in sediments of the

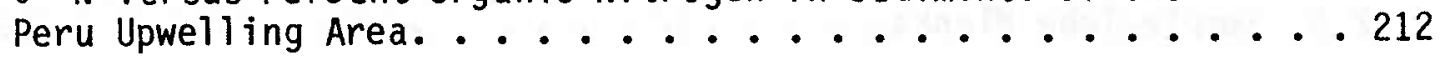

3-44. $\delta 15 \mathrm{~N}$ versus $\mathrm{C} / \mathrm{N}$ Ratio in Sediments of the Peru Upwelling Area. . 214

4-1. Station Location in the Gulf of Maine. . . . . . . 221

4-2. Gulf of Maine: Temperature, Salinity, and Density. . . . . 224

4-3. Gulf of Maine: Nitrate-plus-Nitrite and Ammonia Concentrations. .226

4-4. Gulf of Maine: Dissolved Organic Nitrogen, Total Dissolved Nitrogen, Silicate, Phosphate, and 0xygen Concentrations. . . .228

4-5. Gulf of Maine: $\delta 15 \mathrm{~N}$ and $\delta^{13} \mathrm{C}$ of Plankton, POM, and Surface Sediments $(0-2 \mathrm{~cm}) \ldots . . . . . . .232$

4-6. Gulf of Maine: PON and POC Concentrations. ........ 234

4-7. Gulf of Maine: $\mathrm{C} / \mathrm{N}$ Ratio of Plankton, POM, and Surface Sediment $(0-2 \mathrm{~cm})$, and Total Particulate Matter Concentrations. .236

4-8. Gulf of Maine: Percent Organic Nitrogen and Carbon of Plankton, POM, and Surface Sediments $(0-2 \mathrm{~cm}) \ldots . . . . .238$

4-9. Gulf of Maine Sediments: $\delta 15 \mathrm{~N}$ and $\delta 13 \mathrm{C} . \ldots . . . . .244$

4-10. Gulf of Maine Sediments: Percent Organic Nitrogen and Carbon,

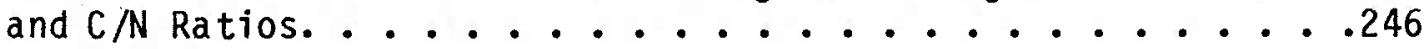

5-1. The Geographic Distribution of $\delta^{15} \mathrm{~N}$ in Nitrate, Plankton, POM,

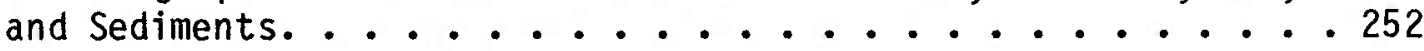

AI-1. Double-Tubo G1 assware. . . . . . . . . . . . 281 


\section{$\underline{\text { LIST OF TABLES }}$}

$\underline{\text { Table }}$

Page

1-1. Nitrogen Isotope Fractionation Factors in Various Biochemical Processes from Wada $(1980) . \ldots 28$

2-1. Glass-Fiber Filter Blanks. . . . . . . . . . . 51

2-2. Effect of Acid Treatment on Percent Nitrogen and $\delta 15_{N}$. . . . 57

2-3. Analyses of Thiourea by Break Seal and Long-Neck Methods. . . . 68

2-4. Molecular Ion Voltages. . . . . . . . . . . . 72

2-5. Sample-Tube Blanks. . . . . . . . . . . . . . . . .

2-6. $\delta 15 N$ of Air Ni trogen. . . . . . . . . . . 80

2-7. Analyses of Thiourea. . . . . . . . . . . . . . .

2-8. Organic-Matter Intercalibration Experiment. ........83

2-9. Analyses of Sediment from Station SEAREX $(2-4 \mathrm{~cm}) \ldots . . . .84$

3-1. Plankton from the Peru Upwelling Area: Percent Organic Nitrogen

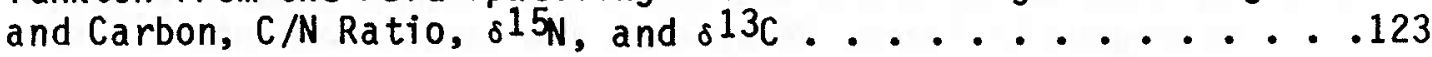

3-2. Surface Sediments $(0-2 \mathrm{~cm})$ from the Peru Upwelling Area: Percent Organic Ni trogen and Carbon, $\mathrm{C} / \mathrm{N}$ Ratio, $\delta 15 \mathrm{~N}$, and $\delta 13 \mathrm{C}$. . . . 202

3-3. Deepest POM and Surface Sediments $(0-2 \mathrm{~cm})$ from the Peru

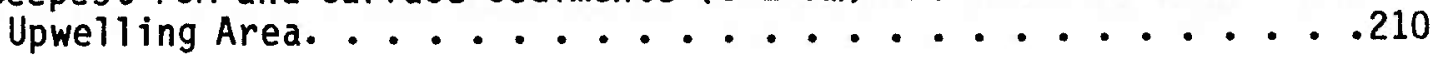

4-1. Plankton from the Gulf of Maine: Percent Organic Nitrogen and Carbon, C/N Ratio, $\delta 15 \mathrm{~N}$, and $\delta 13 \mathrm{C} . \ldots 230$

AI-1.Double-Tube Filter Blanks. . . . . . . . . . . 284

AII-1. Distilled-Water Rinsing Experiment. . . . . . . 286 
CHAPTER I

INTRODUCTION

General Introduction

The organic matter contained within marine sediments is derived from particulate material generated by photosynthetic activity in the surface waters of the ocean. This particulate matter is subject to many biological transformation processes. Phytoplankton, the primary producers, are grazed upon by zooplankton and other nekton, such as fish and whales. These organisms in turn produce particulate organic matter (POM) in the form of fecal material, which also contributes to the particle flux to the sediments. Bacteria, protozoa, and zooplankton feed on this fecal material, as well as on dead tissues, remineralizing the organic matter to soluble form, as well as transforming the chemical form of the particulates. The biological alteration of organic matter occurs throughout the water column. The steadily increasing $C / N$ ratio of POM and the decreases in particulate organic carbon (POC) and nitrogen (PON) concentrations with increasing depth in the water column are evidence for this phenomenon. Particulates caught in sediment traps have also been found to vary as a function of sampling depth in concentration of specific organic compounds and abundance of particle type.

Microbial remineralization of POM generates dissolved inorganic nitrogen (DIN). In addition, zooplankton and fish excrete DIN. This nitrogen is assimilated by phytoplankton which are the base of the marine food web. Thus, remineralization of POM is influential in regulating the rates of productivity of the organisms that originally generated most of the POM. As yet little is known about bacteria and protozoa, but it appears that these micro-organisms may be as important as primary and secondary producers in controlling the fate of POM in the ocean. 
At the sediment/water interface, further remineralization and transformation take place. The nature of these processes has been found to depend on the magnitude of the organic-matter flux to the sediments, the redox conditions, and the amount of benthic activity.

Paleoceanographers have begun to interpret marine sediments as a record of changes in hydrography, biological productivity, and geochemical cycling over geological time. For example $\delta^{18} 0 *$ and $\delta^{13} \mathrm{C}$ in sedimentary carbonates have been used to elucidate changes in water temperatures and sea level. Changes in $\mathrm{C} / \mathrm{N}$ ratio, percent organic nitrogen and carbon have been interpreted as reflecting changes in primary productivity, in the cycling of carbon, as well as in oceanic circulation patterns.

Nitrogen isotope geochemistry promises to be a useful tool in investigating the cycling of PON in the water column with the possibility of application to paleoceanographic interpretations of the $\delta 15 \mathrm{~N}$ sedimentary record. Though less is known about the stable isotope chemistry of nitrogen in comparison to that of carbon, several investigators have observed 1 arge ranges in the $\delta 15_{N}$ of plankton and sediments. In the case of the plankton, this variability is caused by species differences in fractionation of the isotopes, as well as by the uptake of different forms of nitrogen (Wada and Hattori, 1976). In the case of coastal sediments, $\delta 15 \mathrm{~N}$ appears to depend on the amount of

*defined as

$$
\delta=\left\{\frac{R_{\text {sample }}}{R_{\text {standard }}}-1\right\} \times 1000
$$

By definition the $\delta$ value of the standard is $0 \%$.

For $\delta 180, R=180 / 160$ The NBS standard for $\delta 180$ is SMOW. For $\delta 13 \mathrm{C}, \quad \mathrm{R}=13 \mathrm{C} / 12 \mathrm{C}$ The NBS standard for $\delta 13 \mathrm{C}$ is PDB. For $\delta 15 \mathrm{~N}, \quad \mathrm{R}=15 \mathrm{~N} / 14 \mathrm{~N}$ The NBS reference sample for $\delta 15 \mathrm{~N}$ is Air $\mathrm{N}_{2}$. 
terrestrial organic matter present in the sediments (Peters et al., 1978). Sa ino and Hattori (1981) have shown that large variations in the ${ }_{\delta}^{15} \mathrm{~N}$ of PON occur.

Though the data are still quite scanty, it is apparent that identifiable biological processes impart a $\delta^{15} \mathrm{~N}$ signature to organic matter. This seems reasonable, since the largest isotopic fractionations observed in $\mathrm{C}, \mathrm{N}, 0$, and $\mathrm{S}$ in organic matter are associated with biological processes. The largest isotopic alterations within a particular chemical form of the above elements are found when a significant amount has been chemically transformed. For example, the ${ }_{\delta}^{15} \mathrm{~N}$ of nitrate increases as a function of the amount of nitrate reduced to $\mathrm{N}_{2}$ by denitrifying organisms. This is because $14 \mathrm{~N}$ is preferentially reduced, causing the reactant pool to become $15 \mathrm{~N}$-enriched (See Chapter III: Plankton Discussion for a detailed discussion). Since POM is produced and degraded by a wide variety of biological processes, it is a likely component of organic matter to examine for evidence of biologically induced isotopic alteration.

\section{Statement of Thesis Research}

To investigate the fate of POM during its transit through the water column and deposition on the seafloor, isotope studies of nitrogen and carbon were undertaken. The processes focussed on were water-column and sedimentary diagenesis. Since bacteria are known to be important in both processes, their influence on the isotope chemistry of POM was predicted to be important.

The $\delta^{15} \mathrm{~N}$ and $\delta^{13} \mathrm{C}$ of plankton, POM, and sediments from several oceanic sites were related to biological and hydrographic processes identified from nutrient, temperature, and salinity profiles. The sites were chosen to provide samples subject to different mineralization processes (nitrification, denitrification, and sulfate reduction), different lengths of water column (duration of the mineralization 
process), and differences in the size of the organic-matter flux. This

was done to determine what effect these factors have on the ${ }_{\delta}^{1}{ }^{\mathrm{N}}$ of POM. Four stations were occupied in the upwelling area off the coast of Peru and one station was occupied in the Gulf of Maine.

\section{Nitrogen Biogeochemistry}

Dissolved Nitrogen:

Nitrogen is a ubiquitous component of the atmosphere and biosphere, and to a lesser extent, of the lithosphere. Though approximately 80 percent of the atmosphere is composed of $N_{2}$, this 1 arge reservoir (70 percent of the nitrogen present in and above the earth's crust) is relatively inert due to the chemical stability of the $\mathrm{N}-\mathrm{N}$ triple bond. In the biosphere the oxidized forms $\left(\mathrm{NO}_{3}^{-}, \mathrm{NO}_{2}^{-}\right.$, and $\left.\mathrm{N}_{2} \mathrm{O}\right)$ and the reduced forms ( $\mathrm{NH}_{4}^{+}$and organic $\mathrm{N}$ ) are more labile. The biochemical interactions of these compounds are shown schematically in Figure 1-1. These reactions $c$ an be generalized as:

1) Ni trogen Fixation, the conversion of $N_{2}$ to nitrate and ammonia, and subsequently to organic $\mathrm{N}$ : Cyanobacteria and marine plankton such as Trichodesmia are able to fix $\mathrm{N}_{2}$ (Keeney, 1973; Capone and Carpenter, 1982).

2) Nutrient Nitrogen Assimilation, the conversion of DIN into organic compounds: Marine phytoplankton and terrestrial plants obtain essential nitrogen in this manner. It has been suggested that in marine environments nitrogen of ten becones growth 1 imiting. In such situations, marine phy toplankton have been observed to assimilate urea, amino acids and ammonia (Keeney, 1973) in addition to $\mathrm{NO}_{3}^{-}$and $\mathrm{NO}_{2}^{-}$. This widely-held view of phytoplankton nutrition has been modified in response to recent work showing that opportunistic feeding occurs in areas of apparent nitrogen limitation (Goldman, 1980) and that ammonia and urea can be preferentially assimilated even when DIN concentrations are high (McCarthy et a1., 1977). 
Figure 1-1.

Nitrogen Cycle, from Sweeney et al. (1978) 


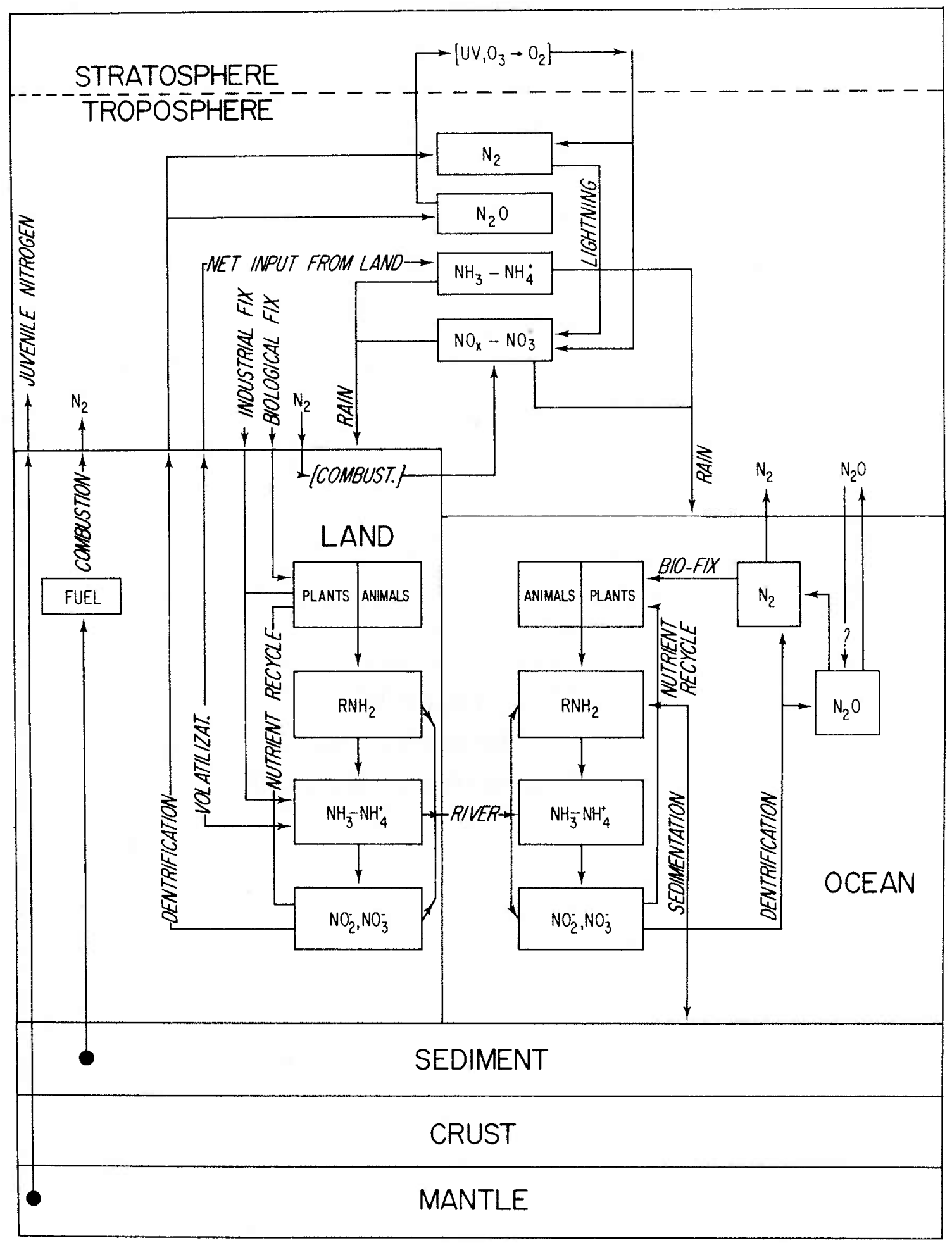


3) Denitrification, the reduction of oxidized nitrogen compounds to $\mathrm{N}_{2}$ using organic matter as an energy source: This reaction occurs in areas of $10 \mathrm{~W} \mathrm{P}_{2}$ in the oceans and soils. In seawater, the conversion is thought to occur in a step-wise manner:

$$
\mathrm{NO}_{\overline{3}} \rightarrow \mathrm{NO}_{\overline{2}} \rightarrow\left(\mathrm{N}_{2} \mathrm{O}\right) \rightarrow \mathrm{N}_{2}
$$

(See Painter, 1970, and Delwiche and Bryan, 1976, for reviews of this subject).

4) Mineralization of Organic Nitrogen Compounds: Heterotrophic bacteria use organic nitrogen compounds present in dead tissues, fecal pellets, and soluble excretion products as energy sources. These bacteria regenerate nutrient nitrogen by degrading organic nitrogen compounds to $\mathrm{NO}_{3}$ in an oxic environment or to $\mathrm{NH}_{4}^{+}$in an anoxic environment (ammonification). The actual route by which POM is metabolized to these end-products $c$ an be circuitous, including many separate steps mediated by different organisms (see Harrison, 1980, for a review of this subject).

5) Nitrification, the sequential conversion of $\mathrm{NH}_{4}^{+}$to $\mathrm{NU}_{2}^{-}$, and then to $\mathrm{N}_{3}$ : Though some heterotrophic nitrification occurs, the majority is autotrophic; i.e. utilizing $\mathrm{NH}_{4}^{+}$. This process is of key importance to productivity, as it determines the relative $\mathrm{NH}_{4}^{+}$ and $\mathrm{NO}_{\overline{3}}$ concentrations in seawater. Since species' preference for the form of nutrient nitrogen varies, the relative concentrations of $\mathrm{NH}_{4}^{+}$and $\mathrm{NO}_{3}^{-}$present will influence the plankton distribution present in the seawater. Nitrosomonas and Nitrobacter are bacteria capable of oxidizing ammonia to nitrite and nitrite to nitrate, respectively (Keeney, 1973). A review of recent rate and bacterial abundance measurements $c$ an be found in Ward et al. (1982).

Within the oxic euphotic zone, fixation, assimilation, and mineralization dominate nitrogen geochemistry. Below this zone, mineralization and nitrification control nitrogen speciation. In areas of 1 ow $\mathrm{pO}_{2}$, denitrification occurs if a sufficient source of energy; 
i.e. organic carbon, is present. Though the occurrence of these reactions is 1 imited by the redox potential of a given environment, the actual limits are not well known. For example, nitrification rates have been observed to be inhibited by very 1 ow $\left(<0.1 \mathrm{ml} / 10_{2}\right)$ and high oxygen concentrations, while denitrification was not observed to occur at oxygen concentrations above $0.14 \mathrm{ml} / 1$ (Sugahara et a1., 1974). It is thought that even if the redox potential of the environment is unfavorable, bacteria can overcome this by clustering to form micro-environments or by inhabiting micro-environments composed of aggregated POM. These micro-environments are pictured as being localized regions of relatively high or low oxygen concentration (Wada et al., 1975).

Nitrifying bacteria have been observed in the open waters of the Atlantic ocean by Watson (1965), Watson (1971), and Ward et al. (1982). Ammonifying, nitrogen fixing, denitrifying, and nitrifying bacteria in coastal sediments have been observed by Sugahara et a1. (1974). In addition to these direct observations, bacterial activity has been indirectly demonstrated through the measurement of the concentrations of water-column and pore-water nitrogen species and through ${ }^{15_{\mathrm{N}} \text {-tracer }}$ studies. For example, Vanderborght and Billen (1975) created a mathematical model including nitrification, denitrification, diffusion, and sedimentation to construct model nitrogen profiles which fit the concentration data of sediments from the Sluice Dock at Ostend (Belgium). Bender et al. (1977), using a similar model on interstitial nitrate profiles from the Guinea Basin in the Eastern Equatorial Atlantic, concluded that the amount of denitrification occurring was considerable and that oceanic pelagic sediments should be investigated as possible sinks for fixed nitrogen.

Al though the geochemistry of nitrogen in the marine environment is dominated by biochemical processes, inorganic and physical processes also exert an influence. For example, molecular diffusion of regenerated fixed nitrogen in the sediments can play a major role in resupplying the 
surface waters in coastal areas with essential nutrient nitrogen (Rowe and Staresinic, in press). In addition, adsorption of ammonia and organic nitrogen compounds onto clay minerals can have a significant effect on the $C / N$ ratio in the sediments by protecting relatively labile organic nitrogen compounds from biochemical and abiotic chemical attack (Muller, 1977). Also, volatilization of reactive nitrogen compounds from seawater and input from atmospheric processes occur, but these fluxes appear to be relatively small. They have been discussed in detail by Hoering (1957) and Freyer (1978).

Abiotic chemical reactions, including condensation and polymerization of "humic" materials, have a strong influence on the molecular form of nitrogen in dissolved organic matter and sediments. The mechanisms of these diagenetic reactions are largely unknown, in part because approximately 50 percent of the nitrogen present in the sediments has not yet been structurally characterized. Current speculation supports the occurrence of condensation reactions, such as those between sugars and amino acids (Hedges, 1978), whose products undergo polymerization to yield complex macromolecules. These polymers may then undergo aromatization and the removal of labile moieties. This process is thought to occur in seawater as well as in the sediments (Nissenbaum, 1974). The resultant polymer could represent a large refractory reservoir of nitrogen whose structure is a function of the quality and quantity of the starting compounds as well as the degree of aging (polymerization and aromatization) which the macromolecule has undergone. The complex, variable, and refractory nature of this material makes characterization and thus geochemical studies difficult.

\section{Particulate Organic Nitrogen:}

Particulate organic matter is an operationally defined term referring to organic matter $(>0.4 \mu \mathrm{m})$ present as solids or adsorbed onto solids in the water column. POM in the marine environment is composed of: eggs, larvae, molts, tests, living and dead plankton, crustacea, fish, fecal 
pellets, bacteria, and amorphous material. The ultimate source of organic matter to the marine sediments is POM. On the seafloor, POM fuels benthic biological activity and in the water column, POM is degraded by bacteria, protozoa, zooplankton, and large fitter feeders such as pteropods and salps, as well as fish and crustacea.

Much of the nitrogen in PON is present as amino acids (Seizen and Mague, 1978; Lee and Cronin, 1982). Nucleic acids, amino sugars, and chitin are also constituents of PON. The concentration of PON has been shown to be a function of surface productivity and its flux through the water column (Gordon, 1971; Staresinic, 1978; Gordon et a1., 1979; Honjo, 1980). The lowest concentrations (0 to $30 \mu \mathrm{g}-a t \mathrm{~N} / 1)(G o r d o n, 1971)$ and the smallest fluxes $\left(0.1\right.$ to $0.5 \mathrm{mg} \mathrm{N} \mathrm{m}^{-2} \mathrm{~d}^{-1}$ ) (Honjo, 1980) are found in the mid-oceanic gyre regions and the highest concentrations ( 1 to $200 \mu \mathrm{g}$-at $\mathrm{N} / 1$ ) (Gagosian, personal communication) and 1 argest fluxes (14.4 to $127.2 \mathrm{mg} \mathrm{N} \mathrm{m}^{-2} \mathrm{~d}^{-1}$ )(Staresinic, 1978) are found in coastal areas especially where upwelling occurs such as off Peru. Within the euphotic zone, concentrations and fluxes decrease dramatically with increasing depth due to remineralization of POM by zooplankton and bacteria. Beneath the euphotic zone, PON concentrations are low and relatively constant down to the seafloor.

Gordon (1977) has shown that the standing crop of PON appears to be temporally variable, even in the deep waters of the open ocean. This observation was the result of both the inhomogeneity in the standing crop and the limitations of sampling randomly spaced and sized particles with 30-1 Niskin bottles. Large particles, which constitute a significant portion of the PON flux, are relatively rare and consequently are not representatively trapped by water bottles. Therefore it is difficult to determine an average PON concentration when sampling with bottles which collect relatively small volumes of water. In-situ large-volume pumps (Bishop et a1., 1977) and sediment traps have been used by several investigators (see Turner and Ferrante, 1979 for a review) to obtain a more representative sample of the water-column particles, since the 
traps are allowed to intercept particles over a relatively long time span during which a large number of particles are collected.

The large particles caught by these traps are primarily zooplankton fecal pellets and aggregates of plankton carcasses, fecal pellets, and bacteria cemented together by mucus. Off the coast of California up to 60 percent of the total flux of PON was found to be composed of this "marine snow". Though the percentage was extremely variable, it appeared to depend on the rates of primary, as well as secondary productivity (A) 1drege, 1979).

These 1 arge particles are relatively rich in fresh organic matter as compared to small particles and ambient seawater. As demonstrated by Shanks and Trent (1979), elevated concentrations of ammonia and phosphate exist within and around these particles, suggesting that rapid remineralization of organic matter is occurring. It is therefore highly likely that large numbers of bacteria are present and active within and upon these particles. As stated by Karl (1982), the direct evidence concerning the presence of bacteria on POM is equivocal. While Gordon (1970), Jannasch (1973), Azam and Hodson (1977), and Linley and Field (1982) report few bacteria associated with particles, Honjo and Roman (1978), Turner (1979), Fellows et al. (1981), Silver and Alldredge (1981), and Gowing (1982) found significant numbers of bacteria present. This apparent discrepancy may be due to natural variability in the nutritive quality and age of the particles, as well as the difficulty of representatively collecting the particles and identifying bacteria.

Evidence that POM is undergoing biochemical transformations below the euphotic zone has been provided by the studies of specific organic compounds such as fatty acids, hydrocarbons, amino acids, and sterols present in the particles. Wakeham et a1. (1980), Lee and Cronin (1982), and Gagosian et a1. (1982b) have shown that the concentrations of these compounds in particles caught by sediment traps vary greatly as a function of depth even in deep water. Microbial transformation of the 
deep-water POM was further suggested by the presence of $B$-alanine (Lee and Cronin, 1982) in the sediment-trap particles.

Our understanding of the fate of PON during its descent through the water column is rudimentary at best. The molecular nature or chemical form of nitrogen is not well known, nor is that of carbon (Cauwet, 1978). The importance of large particles in transporting labile, nitrogen-rich organic matter to the seafloor is just beginning to be shown through sediment trap work. It is also becoming apparent that large particles are oases in the desert of the deep waters, supporting microbial and protozoan activity (Caron et a1., 1982) much larger than found in ambient seawater. It has also been suggested by Jannasch et al. (1982) that rapidly sinking particles are the transportation system by which active bacteria from the surface waters are conveyed to the sediments. In summary, to understand the transport of organic matter to the sediments as well as the cycling of nutrients in the water column, it is necessary to understand the fate of POM in the marine environment.

Nitrogen and Carbon Isotopes as Tracers of Biologically Mediated Reactions in the Marine Environment

Nitrogen-Isotope Geochemistry:

Theory and Laboratory Studies:

The very complicated chemistry of nitrogen in the marine environment is dominated by biochemical reactions as shown in Figure 1-1. As a result, nitrogen exists in a wide variety of oxidation states, ranging from -3 in $\mathrm{NH}_{4}^{+}(\mathrm{aq})$ to +5 in $\mathrm{NO}_{3}^{-}(\mathrm{aq})$. The biochemical reactions which nitrogen undergoes in the marine environment involve the formation and breakage of nitrogen-containing bonds. The two stable isotopes of nitrogen, $14_{\mathrm{N}}$ and $15 \mathrm{~N}$, undergo the same reactions, but differ in their rates of reaction because of the difference in vibrational energy 
of the activated transition state complexes. For kinetically controlled* reactions, this difference gives rise to isotopic fractionations. Usually the lighter isotope reacts more readily than the heavier isotope causing the products to become enriched in the light isotope. The size of this enrichment is a function not only of the relative vibrational stretching frequencies of the bonds undergoing reaction, but also of the temperature and extent of reactant depletion.

A quantitative measure of the degree to which one isotope is selected over another during a particular reaction is given by a fractionation factor defined as,

$$
\begin{aligned}
& a=\frac{14 k}{15_{k}}=\frac{R_{r}}{R_{p}} \\
& 14_{k}=\text { rate constant for the light isotope } \\
& 15_{k}=\text { rate constant for the heavy isotope } \\
& R_{r}=(15 \mathrm{~N} / 14 \mathrm{~N}) \text { of reactant } \\
& R_{p}=(15 \mathrm{~N} / 14 \mathrm{~N}) \text { of product } \\
& \star \star T h i s \text { approximation is valid only if the reactant pool } \\
& \text { size has not been diminished by more than } 5 \text { percent } \\
& \text { (Wada, 1980). }
\end{aligned}
$$

To calculate a theoretical fractionation factor, the vibrational energy of the transition state complex for each isotope must be known. Due to

*In addition to kinetically induced fractionations, isotopic partitioning also arises from equilibrium exchange reactions. In this case, the fractionation factor is a function of the vibrational energy of the nitrogen-containing bonds undergoing isotopic exchange. Chemical equilibrium must occur before isotopic equilibrium can be attained (See Hoefs, 1980 for a detailed discussion). As described above, most reactions which nitrogen undergoes in the marine environment are uni-directional in nature and thus are kinetically controlled. Consideration of isotopic equilibrium may be useful in determining the $15 \mathrm{~N}$ distribution in two qualified situations, i.e. during dissolution of $\mathrm{N}_{2}$ at the sea-surface when denitrification and $\mathrm{N}_{2}$ fixation are absent and during adsorption/desorption of ammonia on clay minerals when ammonia is not being produced or consumed. 
ignorance of the details of the reaction mechanism, the configuration of the transition state is usually not known, making calculations of fractionation factors impossible. Empirical determinations of fractionation factors have been made for a few biochemically mediated reactions. As shown in Table 1-1 from Wada (1980), almost every process induces some fractionation, though the extent of fractionation for a specific reaction can be variable. At least some of this variation may be due to alterations in metabolic pathways and rates caused by changes in physiology. For example, Wada and Hattori (1976) have shown that the ${ }^{1} 15_{\mathrm{N}}$ of a single species of phytoplankton can vary as a function of growth rate or the form of nitrogen assimilated. Environmental factors, such as light intensity and nutrient concentrations, may also be important in determining the $\delta^{15} \mathrm{~N}$ of plankton, as they influence growth rates.

To convert a values to $\delta^{15} \mathrm{~N}$ values, the following equation can be used:

$$
\alpha=\left\{\frac{\left(\frac{\delta^{15} N_{r}}{10^{3}}\right)+1}{\left(\frac{\delta N_{p}}{10^{3}}\right)+1}\right\}
$$

If $\delta 15 \mathrm{~N}_{\mathrm{r}}$ is assigned a value of $00 / 00$,

$$
{ }^{15} N_{p}=\left[\begin{array}{ll}
\frac{1}{\alpha} & -1
\end{array}\right] 10^{3}
$$

Thus if $\alpha=1.010$, the $\delta 15 \mathrm{~N}$ of the product is $100 / 00$ lower than that of the reactant. If $\alpha=0.990$, the $\delta 15 \mathrm{~N}$ of the product is $100 \%$ higher than that of the reactant. Using the above equation, the fractionation factors in Table 1-1 have been converted to $\delta 15 \mathrm{~N}$ values and are schematically shown in Figure 1-2 in which $\delta 15_{r}$ is denoted by the points at $0 \% / 00$ and the $\delta 15 \mathrm{~N}$ of the product is shown by the 
Table 1-1.

Nitrogen Isotope Fractionation Factors in Various Biochemical Processes from Wada (1980)

Reaction

Apparent isotope fractionation factor

Organism

Reference

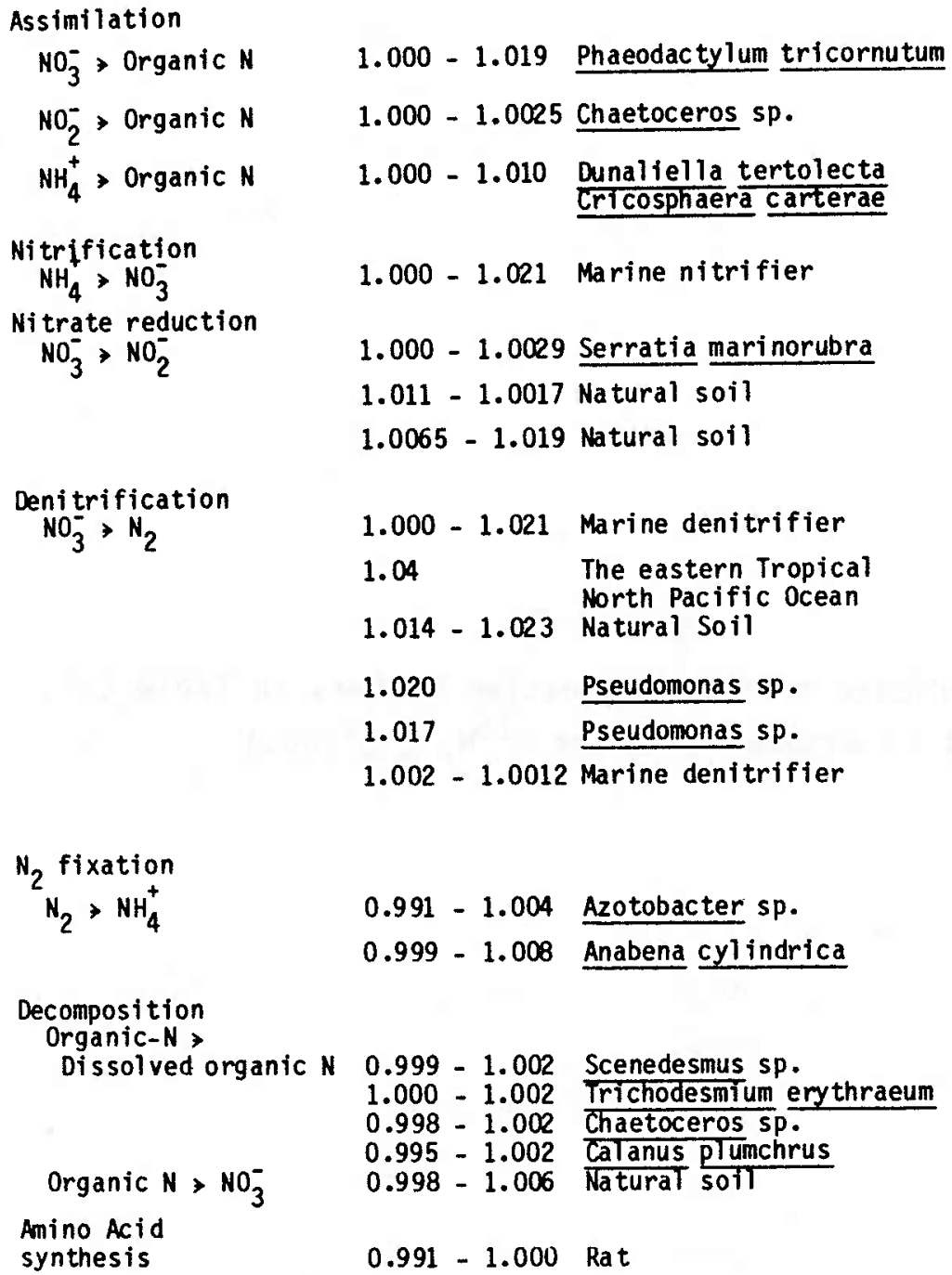

Wada and Hattori, 1978

Wada, 1980

Wada, 1980

Wada, 1980

Miyake and Wada, 1971

Miyazaki, 1971

Bl ackmer and Bremer, 1977

Chien et a1., 1977

Miyake and Wada, 1971

Cline and Kaplan, 1975

Bl ackmer and Bremner, 1977

Wel Tman et al., 1968

Delwiche and Steyn, 1970

Koike and Hattori, unpublished

Hoering and Ford, 1960

Minagawa and Wada, 1978

Miyake and Wada, 1971

Rennie et a1., 1976

Gaebler et a 1., 1966 
Figure 1-2.

The $\delta^{15} \mathrm{~N}_{\mathrm{p}}$ Predicted from Fractionation Factors in Table 1-1.

(It is assumed that the $\delta^{15} \mathrm{~N}_{r}=0 \%$. 


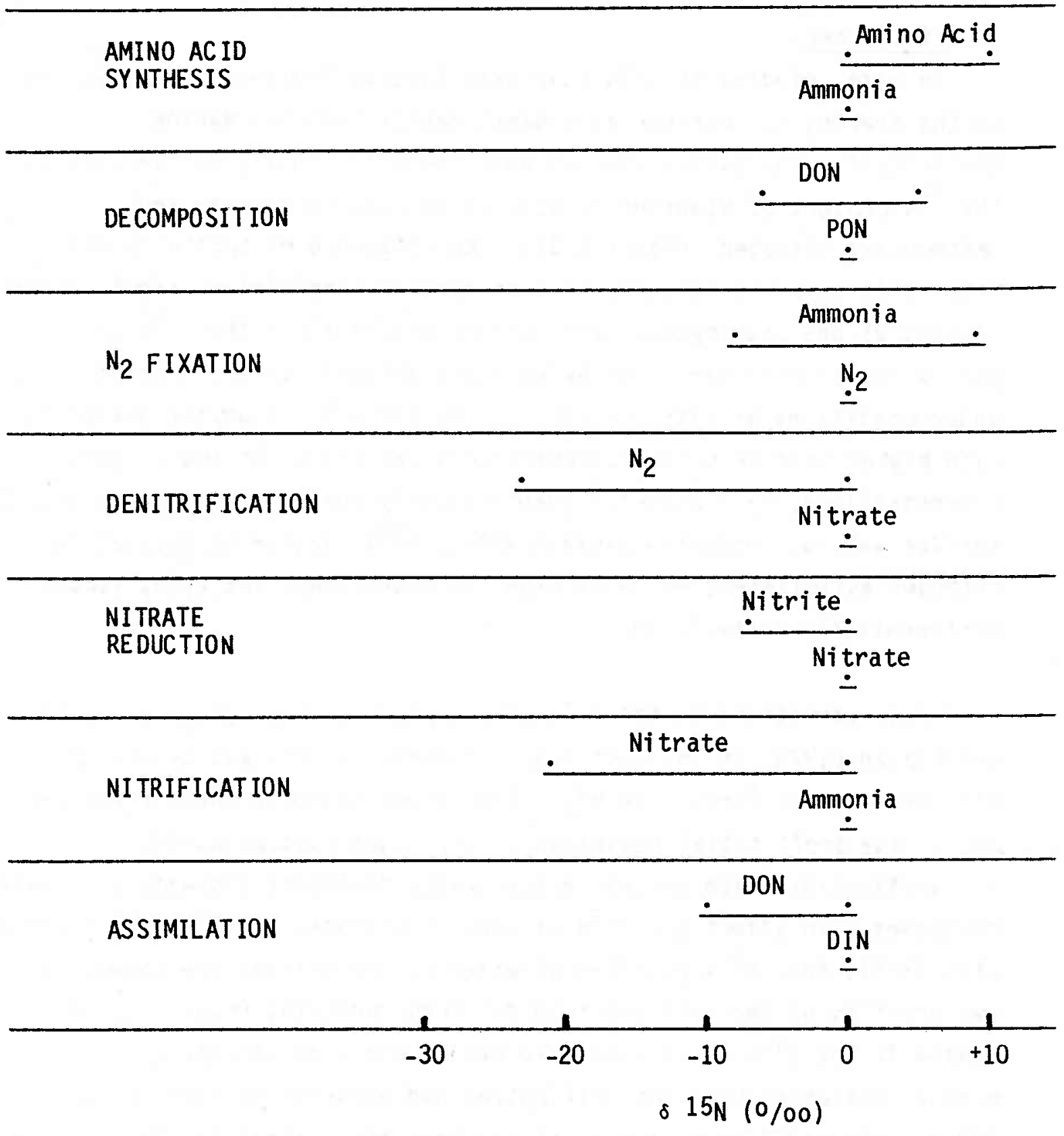


range of values determined by the reported range in $\alpha$. As mentioned earlier, it is assumed that reactant depletion is not 1 arge enough to alter the $\delta^{15} \mathrm{~N}$ of the reactant pool.

\section{Field Work:}

To date, studies of $\delta 15 \mathrm{~N}$ have been 1 argely 1 imited to surveys and to the tracing of terrestrial organic matter into the marine environment. The survey studies have demonstrated a great variability in the $15_{\mathrm{N}}$ content of plankton as well as in oceanic nitrate and sedimentary nitrogen (Figure 1-3). The influence of spatially and temporally variable factors, such as species composition, 1 ight, nutrient concentrations and phytoplankton bloom conditions on the $\delta^{15_{\mathrm{N}}}$ of phytoplankton has been shown by Wada and Hattori (1976). For example, under conditions of nitrogen 1 imitation, the $\delta 15 \mathrm{~N}$ of phytoplankton is much higher than when DIN concentrations are high. At low ambient concentrations, phytoplankton quantitatively remove the nitrogen from the surface waters, producing biomass with a $\delta^{15} \mathrm{~N}$ similar to that of the nitrogen assimilated, while at high concentrations, the light isotope is preferentially assimilated.

Large variations in the $\delta^{15} \mathrm{~N}$ of nitrate have been observed by $\mathrm{Cline}$ and Kaplan (1975) in the East Tropical North Pacific and by Liu (1979) off the coast of Peru. The high $\delta 15 \mathrm{~N}$ values found in these areas are due to the preferential reduction of the light isotope during denitrification which occurs in the oxygen-deficient mid-waters. Mixing processes also affect the $\delta 15 \mathrm{~N}$ of oceanic nitrate. In Figure 1-4 (from Liu, 1979), four $\delta^{15} \mathrm{~N}$ profiles of water-column nitrate are shown. The two profiles on the left are from the Peru Upwelling Area. The mid-water maxima in the $\delta^{15} \mathrm{~N}$ of nitrate were coincident with nitrate-plus-nitrite minima indicating that denitrification had occurred between 100 to $500 \mathrm{~m}$. The profiles on the right are from the Central Pacific and the Northwestern Pacific Ocean where denitrification is absent.

Values ranging from +2 to $+10 \%$ (Figure $1-5$ ) have been reported 
Figure 1-3.

Distribution of $\delta^{15} \mathrm{~N}$, from Macko (1981) 


\begin{tabular}{|c|c|}
\hline $\begin{array}{l}\text { SOIL CHEMICAL } \\
\text { CONSTITUENTS }\end{array}$ & $\begin{aligned} & \text { HEXOSAMINE } \stackrel{\longmapsto}{\longmapsto} \mathrm{NH}_{4}^{+} \\
& \text {NON-HYDROLZ.H } \longmapsto \text { AMINO ACID }\end{aligned}$ \\
\hline METEORITES & $\bullet \quad \infty \bullet \quad \longmapsto \bullet$ \\
\hline TERRESTRIAL & RIVER ORGANIC-N \\
\hline VOLCANIC $\mathrm{NH}_{4} \mathrm{Cl}$ & $\mathrm{NH}_{4}^{+} \longmapsto \mathrm{NH}_{3}$ \\
\hline NATURAL GAS & $\longmapsto$ \\
\hline OIL & CRUDE Ю \\
\hline COAL, PEAT & $\longmapsto$ \\
\hline LAND PLANTS & $\longrightarrow$ \\
\hline LAND ANIMALS & $\mapsto$ \\
\hline SEAWATER & $\underset{\mathrm{NO}_{3}^{-} \mathrm{H}_{2}^{-1}}{\stackrel{1}{H}} \mathrm{NH}_{4}^{+}$ \\
\hline MARINE PLANTS & 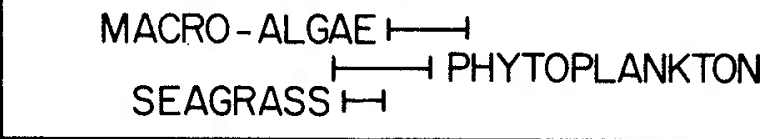 \\
\hline $\begin{array}{l}\text { MARINE } \\
\text { ANIMALS }\end{array}$ & ZOOPLANKTON \\
\hline $\begin{array}{l}\text { MARINE } \\
\text { SEDIMENTS }\end{array}$ & $\begin{array}{l}\text { PARTICULATE } \\
\text { ORGANIC NITROGEN }\end{array}$ \\
\hline ATMOSPHERE & 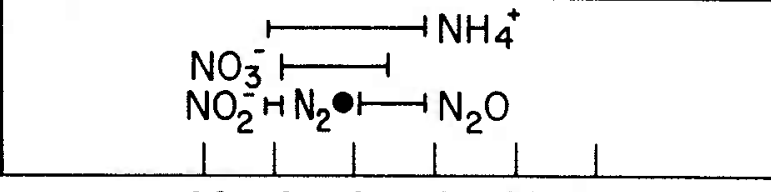 \\
\hline & $\begin{array}{c}-20-10 \quad 0 \\
\delta^{15} N(\%)\end{array}$ \\
\hline
\end{tabular}


$-34-$

Figure 1-4. $\delta^{15} N$ of Nitrate, from Liu (1979) 

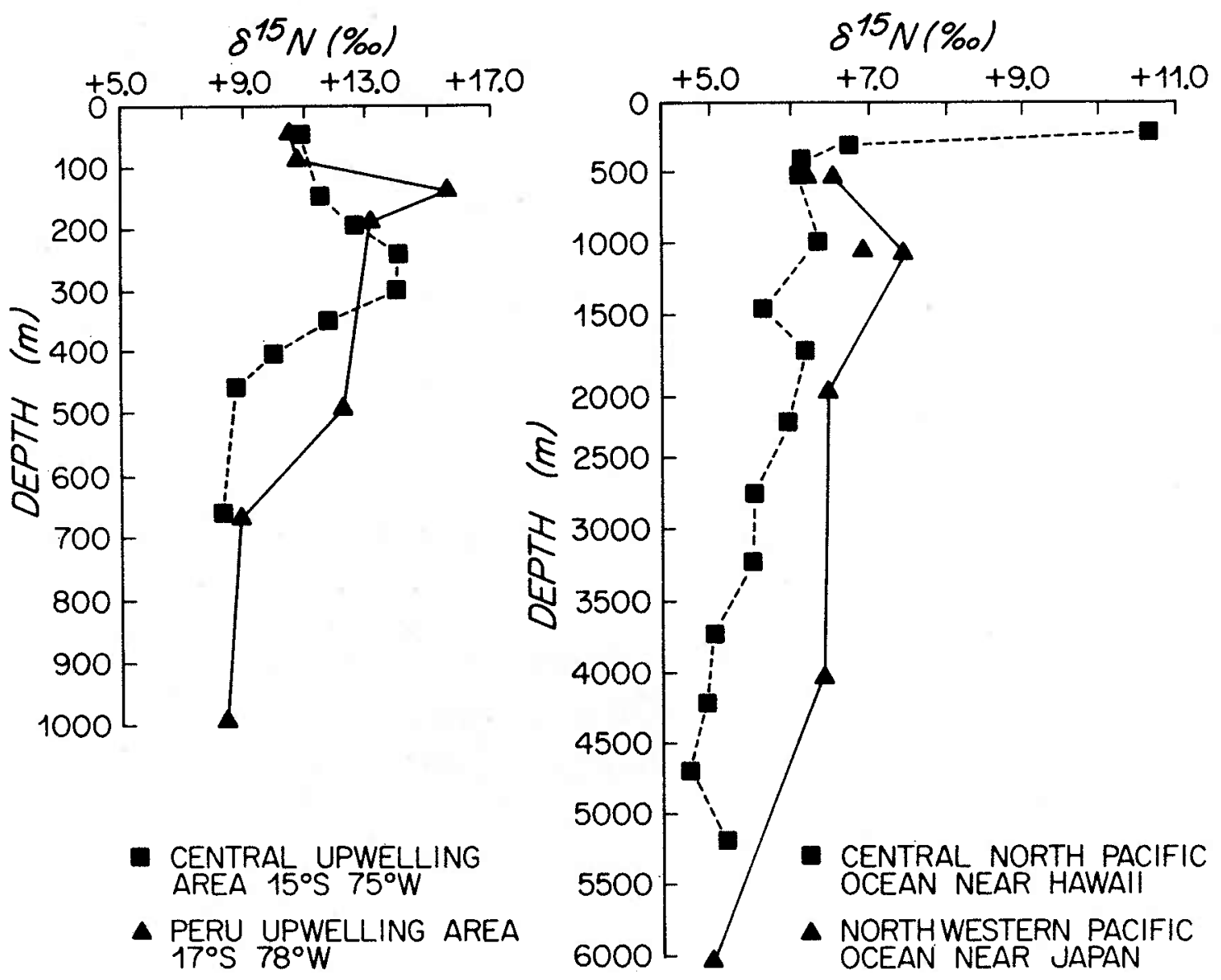
Figure 1-5.

Nitrogen and Carbon Isotope Ratios of Sedimentary Organic Matter from Coastal California, from Peters et a1. (1978) 


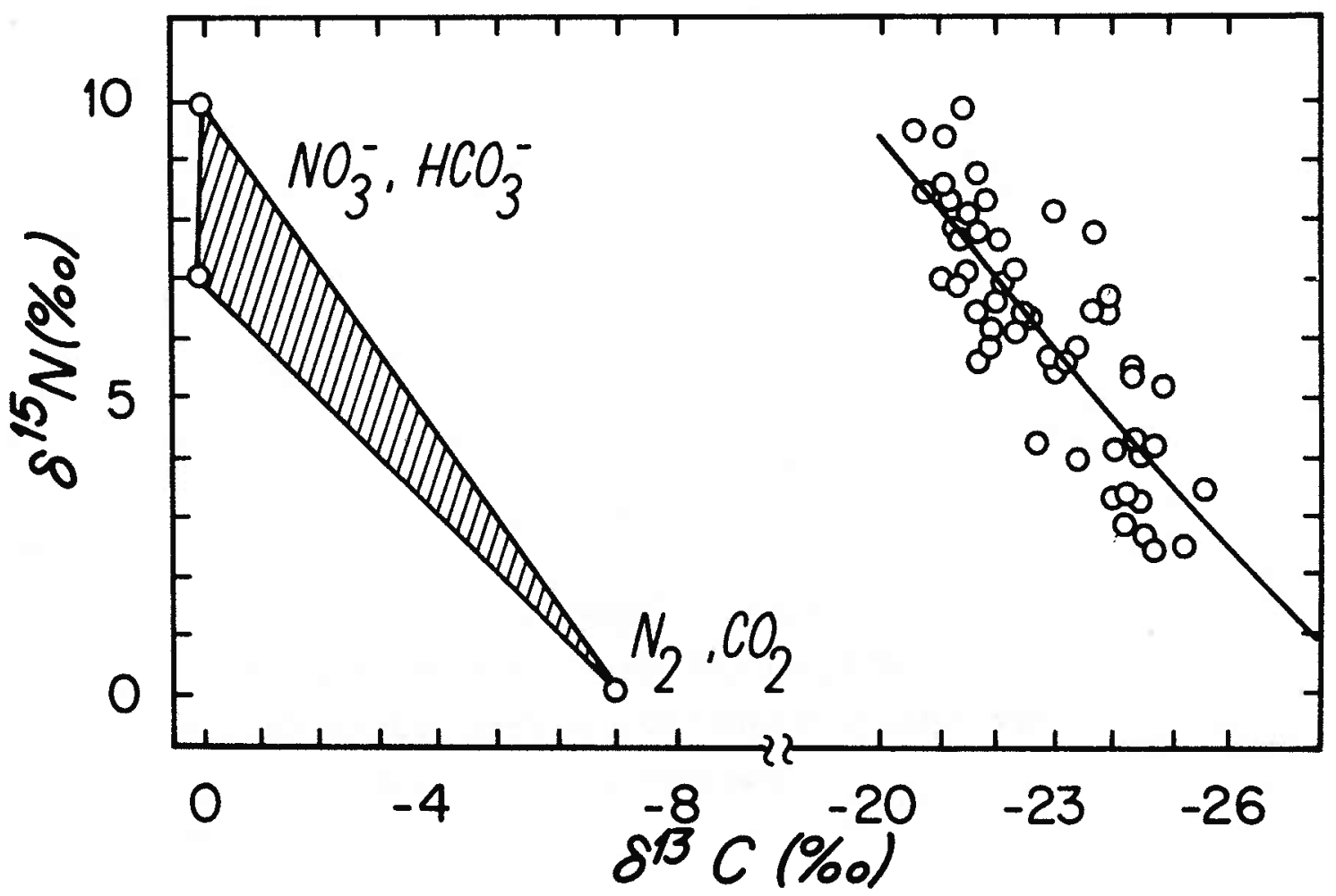


for sedimentary organic matter. Peters et al. (1978) interpreted a positive correlation between $\delta^{13} \mathrm{C}$ and $\delta^{15_{\mathrm{N}}}$ in California coastal sediments to be the result of a two end-member mixing process, the marine organic matter being diluted by terrestrial organic matter. Using the limited information available, a theoretical mixing curve was constructed with the source end members for the organic matter being defined as

1) Terrestrial: $\delta^{15} \mathrm{~N}=0^{0} / 00, \delta^{13} \mathrm{C}=-7^{0} / 00$

(The $\delta^{15} \mathrm{~N}$ end member of $0^{0} / 00$ is that of a ir nitrogen which is converted to organic matter by $\mathrm{N}_{2}$ fixers and the ${ }^{13} \mathrm{C}$ end member of $-7^{0} / 00$ is that of atmospheric $\mathrm{CO}_{2}$ which is used by terrestrial plants.)

2) Marine: $\delta^{15} \mathrm{~N}=+7$ to $+10^{0} / 00, \delta^{13} \mathrm{C}=0^{0} / 00$

(The $\delta^{15 \mathrm{~N}}$ end member of +7 to $+10^{\circ} \% 0$ represents the nitrate assimilated by marine phytoplankton and the $\delta^{13} \mathrm{C}$ end member of $0^{\circ} / 00$ is that of $\mathrm{HCO}_{3}$, the source of carbon for marine photosynthetic organisms.)

To the right of the theoretical mixing line shown in Figure 1-5, are the sedimentary data. The offset in $\delta^{13} \mathrm{C}$ is the result of fractionation which occurs during photosynthetic production of POM by phy toplankton. The similarity in slope between the theoretical mixing line and the least squares fit of the data was interpreted as evidence for the importance of mixing of terrestrial and marine organic matter in determining the $\delta^{15} \mathrm{~N}$ of the sediments. The assumption was made that no fractionation of the nitrogen isotopes occurred either during transport of the organic matter through the water column or prior to burial in the sediments. The linear relationship does have a great deal of scatter in it suggesting the importance of other factors, such as the length of the water column, the size of the particulate flux, and specific drainage conditions, in determining the isotopic composition of the sediments.

The assumption of minimal isotopic alteration during diagenesis has 
been made implicitly and explicitly by numerous investigators because of the absence of gradients in sedimentary organic matter $\delta 15 \mathrm{~N}$ profiles (Pang and Nriagu, 1976; Pang and Nriagu, 1977; Stuermer et a1., 1978; Sweeney et a1., 1978; Sweeney and Kaplan, 1980). The similarity of the few measurements of the $\delta 15 \mathrm{~N}$ of pore-water $\mathrm{NH}_{4}^{+}$to that of total organic matter of the sediments has also suggested that diagenetic isotopic alteration was unimportant (Sweeney and Kaplan, 1980).

Prior to this thesis research, the only evidence for isotopic alteration of PON during transit through the water column was that reported by Saino and Hattori (1980) for the northeastern Indian Ocean (See Figure 1-6). These workers observed a minimum in the $\delta 15 \mathrm{~N}$ of water-column particulate matter which coincided with the mid-water oxygen minimum and the nitrate maximum. The 1 argest changes in $\delta 15 \mathrm{~N}$ occurred within the zone of remineralization. In addition, the deep-water particulates were extremely enriched in $15 \mathrm{~N}$; the $\delta 15 \mathrm{~N}$ of the POM being much higher than that of any sediments yet analyzed.

Since the POM in that study was collected in 30-1 Niskin bottles, the authors suggested that the samples were biased towards the small particle fraction. They reported that the $\delta 15 \mathrm{~N}$ values of sediment-trap samples from the North Pacific were much lower than the $\delta 15 \mathrm{~N}$ values of POM in the Indian 0cean. The $\delta^{15 \mathrm{~N}}$ values of the trap samples were also lower than that of any marine sediment yet analyzed, except for sediments in the mud lens located on the shelf break in the Peru Upwelling Area (Reimers, 1981)(See Chapter III: Sediments for a detailed discussion). The value of comparing results from these geographically disparate sites is questionable. Nevertheless, these results suggest a differential transport of nitrogen isotopes in POM, with the large, relatively unaltered particles being depleted in $15_{N}$, and the small, refractory particles being enriched in $15 \mathrm{~N}$. If this is the case, mixture of these two inputs would yield sedimentary organic matter with a $\delta 15 \mathrm{~N}$ value between that of the large and small particle fractions. The effect of benthic reworking on surface sediments was not considered, though large 
Figure 1-6.

$\delta^{15} \mathrm{~N}$ of Particulate Organic Ni trogen

in the Northeastern Indian Ocean, from Saino and Hattori (1980) 


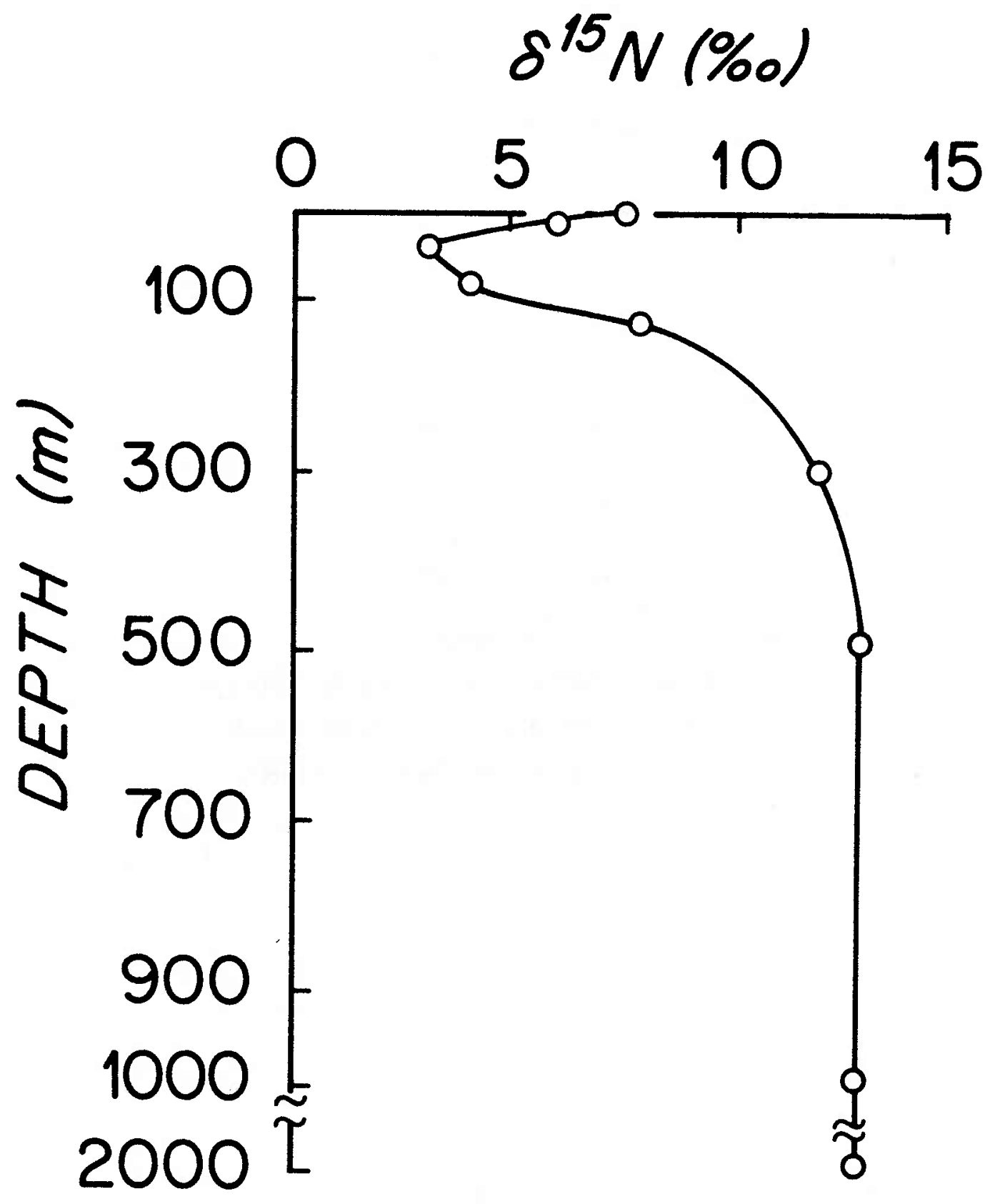


differences in organic-matter content have been shown to exist between deep-water particulates and surface sediments (Cole, 1982).

Carbon-Isotope Geochemistry:

The ${ }^{13} \mathrm{C}$ of POC has been found to range from -19 to $-28 \%$ (See Jeffrey et a1., 1982, for a review of this subject). In comparison, the ${ }^{13} \mathrm{C}$ of dissolved organic carbon (DOC) is relatively constant, ranging from -22 to $-24 \%$. The size of the DOC pool is more than one order of magnitude larger than the POC pool. The relative isotopic homogeneity of the DOC suggests that the residence time of DOC in the ocean is very 1ong. On the other hand, the 1 arger range in $\delta^{13} \mathrm{C}$ of POC suggests a much shorter residence time in the water column during which biological processes alter the ${ }^{13} \mathrm{C}$ content to variable degrees (Eadie et al., 1978).

The ${ }^{13} \mathrm{C}$ of surface sediments have been found to be approximately 1.0 to $6.5 \%$ higher than the $\delta 13 \mathrm{C}$ of deep-water POC (Williams and Gordon, 1970; Eadie and Jeffrey, 1973; Gormly and Sackett, 1975; Tan and Strain, 1979). This suggests that deep-water POC is either reworked at the sediment/water interface and/or deep-water POC is not the sole source of organic carbon to the sediments. As pointed out by Eadie and Jeffrey (1973), there is a greater than order-of-magnitude difference between the organic carbon content of deep-water POC and sediments. Thus it is plausible that large isotopic alterations might occur during diagenesis at the sediment/water interface. If this is the case, DOC and dissolved inorganic carbon (DIC) in the pore waters should represent a sink for ${ }^{12} \mathrm{C}$. Brown et a1. (1972) have reported that the ${ }^{13} \mathrm{C}$ of $\mathrm{DOC}$ in the pore waters of the anoxic sediments of Saanich inlet was $-21.8 \%$, approximately that of the sediments. Al though the DOC concentrations increased with increasing depth as organic compounds were solubilized during diagenesis, there was no accompanying gradient in $\delta^{13} \mathrm{C}$. This suggests that isotopic alteration did not occur in the sediments, though fractionation at the sediment/water interface can not be ruled out. 
Carbon dioxide is also generated by decomposition of organic matter in the sediments, but the isotopic signal produced by accumulation of this ${ }^{3} \mathrm{C}$-depleted $\mathrm{CO}_{2}$ in the pore waters is obscured by dissolution of $\mathrm{CaCO}_{3}$

Because the various methods used to collect POM tend to bias the samples to certain particle sizes, it is difficult to determine the $\delta^{13} \mathrm{C}$ of the source of organic matter to the sediments. The $\delta^{13} \mathrm{C}$ of particles caught in Niskin bottles by Eadie and Jeffrey (1973) was several permil lower than that of the underlying sediments in the Gulf of Mexico and the southern Indian Ocean. These investigators al so collected particles by in-situ filtration which is more efficient at collecting rapidly sinking particles. In the eastern Gulf of Mexico, no difference was found between the $\delta^{13} \mathrm{C}$ of particles collected in Niskin bottles as compared to that of particles collected by in-situ filtration. In the western Gulf of Mexico, the $\delta^{13} \mathrm{C}$ values of in-situ filtered samples from 200,1500 , and $3000 \mathrm{~m}$, were $5.0,2.6$, and $1.3 \%$ higher respectively, than those of samples collected in Niskin bottles. Still the ${ }^{13} \mathrm{C}$ of the $3000-m$ in-situ pump sample was $1.5 \%$ that of the underlying sediments suggesting the occurrence of post-depositional isotopic alteration.

There is evidence from several other studies that ${ }^{13} \mathrm{C}$ varies with particle size. Bishop (1977) also collected POC with an in-situ large volume filtration system. In the equatorial Atlantic he found that most of the particles in the upper $400 \mathrm{~m}$ of the water column were 1 to $53 \mu \mathrm{m}$ in size. The $\delta^{13} \mathrm{C}$ of the large particle fraction (>53 $\mu \mathrm{m}$ ) was relatively constant $\left(-23\right.$ to $\left.-24^{\circ} / 00\right)$, while the $\delta^{13} \mathrm{C}$ of the smaller size fractions $(1-53 \mu \mathrm{m}$ and $<1 \mu \mathrm{m})$ varied greatly, reaching minimum values of -24 and $-270 \%$, repectively. These data suggest that in the upper 400 meters of the water column, particles with different sinking rates also have different $\delta^{13} \mathrm{C}$ values. This may have been due to differences in residence time in the water column (large particles sink too fast to become isotopically altered) and/or chemical differences 
(1arge particles do not support biochemical processes which alter ${ }^{13} \mathrm{C}$ in small particles). Samples were not collected from deep waters, so the impact of different size fluxes on the sedimentary ${ }^{13} \mathrm{C}$ can not be determined.

The relationship between the ${ }^{13} \mathrm{C}$ of bottom-water $\mathrm{POC}$ and the sedimentary organic carbon is geographically variable. Deuser and Ross (1980) reported a $\delta^{13} \mathrm{C}=-21.4 \pm 0.3 \%$ for POC collected over two-month intervals for two years at 3200-m water depth, 25 nautical miles southeast of Bermuda. Though the carbon flux to the deep waters changed seasonally by a factor of seven, the ${ }^{13} \mathrm{C}$ of POC was constant, suggesting that mid-water decomposition homogenizes the isotopic content. The ${ }^{13} \mathrm{C}$ of the surface ( 0.5 to $1.0-\mathrm{cm}$ depth interval) sediment was $-22.6 \%$ (Deuser, personal communication). This observation is the only report of the $\delta^{13} \mathrm{C}$ of an underlying sediment being lower than that of deep-water POC. Though the sediments represent a long-term average in the ${ }^{13} \mathrm{C}$ of accumulating $\mathrm{POC}$, the temporal constancy in the ${ }^{13} \mathrm{C}$ of deep-water POC suggests that ${ }^{13} \mathrm{C}$ is lost during diagenesis. Degens (1969) has suggested that the loss of the ${ }^{13} \mathrm{C}$-enriched carboxyl moiety of amino acids during diagenesis causes ${ }^{13} \mathrm{C}$ depletion in the residual organic matter.

A third kind of relationship between the $\delta^{13} \mathrm{C}$ of bottom-water POC and the underlying sedimentary organic carbon has been observed. Crisp et al. (1979) and Venkatesan et a1. (1980) have analyzed sediment-trap material and surface sediments from two coastal California basins where rapid sedimentation is caused by 1 arge amounts of primary production and anthropogenic input. The organic matter analyzed was separated into a humic and kerogen fraction. The results of isotopic analyses showed no difference in ${ }^{13} \mathrm{C}$ nor in the percentage of carbon and nitrogen between the trap particles and surface sediment. This suggests that transport through the water column and deposition were too rapid for either chemical or isotopic alteration to take place, a very unusual situation even in anoxic environments. This conclusion is based upon the 
assumption that POC caught in the traps represented the primary source of organic matter to the sediments.

\section{Stable Isotope Geochemistry and the Fate of POM}

Thus far, it has been shown that nitrogen isotopes may be useful in studying phytoplankton nutrition (Wada and Hattori, 1976), determining the relative abundance of terrestrial organic matter in coastal sediments (Peters et al., 1978), and examining the production and degradation of POM (Saino and Hattori, 1980). Furthermore, from the available data concerning the $\delta^{15} \mathrm{~N}$ and $\delta^{13} \mathrm{C}$ of POM, it is appears that:

1) isotopic alteration of POM takes place during transit through the water column,

2) the $\delta^{15} \mathrm{~N}$ and $\delta^{13} \mathrm{C}$ of POM and sediments are geographically variable and,

3) the $\delta^{13} \mathrm{C}$ and possibly the $\delta 15 \mathrm{~N}$ of POM varies as a function of particle size.

What is unclear is the relationship between the isotopic content of the sediments and the source organic matter, presumably POM. Improvements in particle collection will greatly aid the investigation of this relationship. The effect of water-column regeneration processes, sinking time, and chemical composition on the $\delta^{15} \mathrm{~N}$ and $\delta^{13} \mathrm{C}$ of the different size fractions of POM is not wel1-known and needs to be quantified for different marine environments. The effect of diagenesis on the distribution of $\delta^{15} \mathrm{~N}$ and $\delta^{13} \mathrm{C}$ in the sediments is also unclear. In sediments undisturbed by bioturbation, closely spaced sampling of the top few centimeters may reveal gradients in $\delta^{15} \mathrm{~N}$ and ${ }^{13} \mathrm{C}$ associated with remineralization of organic matter. The isotopic content of the sediments should be the result of deposition of POM with ${ }_{\delta}^{15} \mathrm{~N}$ and $\delta^{13} \mathrm{C}$ values determined by water-column processes and isotopic alteration associated with diagenesis.

Since the $\delta^{15} \mathrm{~N}$ and $\delta^{13} \mathrm{C}$ of POM have been shown to be the result 
of biological processes which control the composition and fate of the particles, the nitrogen and carbon isotopes are useful in investigating the cycling of POM in the marine environment. This thesis research was undertaken to further investigate which processes are influential in determining the isotopic content of POM and the sediments. With a better understanding of these processes, it may be possible to interpret the down-core distributions of $\delta 5^{15}$ in terms of changes in accumulation and post-depositional alteration over geologic time. 
CHAPTER II:

SAMPLING AND ANALYTICAL METHODS

Sampling

Four stations were occupied in the Peru Upwelling Area in March through April of 1981 and one station in the Gulf of Maine in August of 1980. At each station, plankton, POM, sediments, and water for nutrient analyses were collected. The station locations are shown in Figures 3-2 and 4-1. Details on sample collection are given below.

\section{Sediment:}

Two different gravity corers were used: a 7-cm diameter barrel in the Gulf of Maine and a $10-\mathrm{cm}$ diameter barrel off the coast of Peru. Upon arrival on deck, the overlying water was drained from the core top and the core was immediately frozen. Sectioning was done several months later just prior to isotope analysis. The core barrel was split longitudinally and samples were removed from the inner part of the core, well away from contact with the core barrel.

\section{Plankton:}

Plankton tows were made with a 1-m diameter opening, 333-um mesh plankton net, towed obliquely through the top 10 meters of the water column. Although the mesh size of the net may have biased the net catch to large $(>333 \mu)$ organisms, after a tow the net was always clogged. This suggests that a significant fraction of the smaller organisms was collected. In the Gulf of Maine, the plankton were separated into two size fractions $(>10 \mu \mathrm{m}$ and $<10 \mu \mathrm{m})$, by washing part of the catch through a 10- $\mu \mathrm{m}$ Nitex screen using surface seawater. The size fractions were stored in acid-cleaned glass jars and kept frozen until the time of analysis. For the Peru samples, size separations were done in the lab

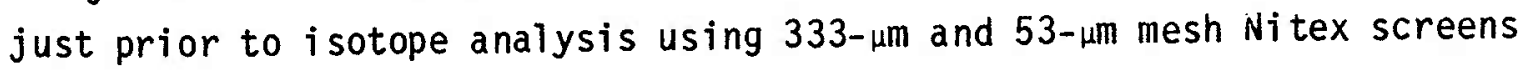
and Sargasso seawater. This produced three size fractions: $>333 \mu \mathrm{m}$, 
53-to-333 $\mu \mathrm{m}$, and $<53 \mu \mathrm{m}$.

Particulate Matter:

Particulate matter was collected by three methods:

On-deck Filtration:

Thirty-liter Niskin bottles were used off the coast of Peru and in the Gulf of Maine to collect water for immediate filtration through Gelman A/E binderless glass-fiber filters (47-mm diameter) having a $0.3-\mu \mathrm{m}$ pore size. The filtration was done with a graduated 18-1 glass carboy fitted with a rubber stopper having two ports with valves, one attached to a vacuum pump and the other to the outlet of a $47-\mathrm{mm}$ plastic Millipore filter holder (see Figure 2-1). The filter inlet was connected to the 30-1 Niskin bottle. Evacuating the carboy initiated filtration, which was continued until either the filter clogged or the Niskin bottle was emptied. The Niskin bottles were shaken periodically to help keep particles suspended. Filtration of a 30-1 Niskin bottle took less than 30 minutes except at Station $A$ off the coast of Peru where 1 to 101 iters of seawater clogged the filters. At Station $C$ off the coast of Peru, several hydrocasts were done to provide 60 to 1201 of water for filtration. The salinity and temperature profiles (Figure 3-14) verified that the Niskin bottles were placed at similar depths from cast to cast.

The glass-fiber filters used for filtering particles were cleaned by soaking in hot concentrated sulfuric acid for 24 hours. The filters were rinsed with distilled water until the wash water had a pH 7.0. The filters were then combusted at $500^{\circ} \mathrm{C}$ for 24 hours and stored in acid-cleaned Petri dishes. Blank filters were analyzed along with samples to determine the level of nitrogen and carbon contamination. The results are shown in Table 2-1. About $0.4 \mu$ moles of $N$ and $10.7 \mu$ moles of $C$ were present on combusted filters which had been taken to sea. These levels were considerably higher than those $(<0.04 \mu$ moles of $N$ and $<3.0$ umoles of $C$ ) measured by $C H N$ analysis before taking the filters to sea. Average values of $0.38 \mu$ moles $N$ with a $\delta^{15} \mathrm{~N}$ of $+6.2 \%$ and 
$-49-$

Figure 2-1.

Particulate-Matter Filtration Apparatus 


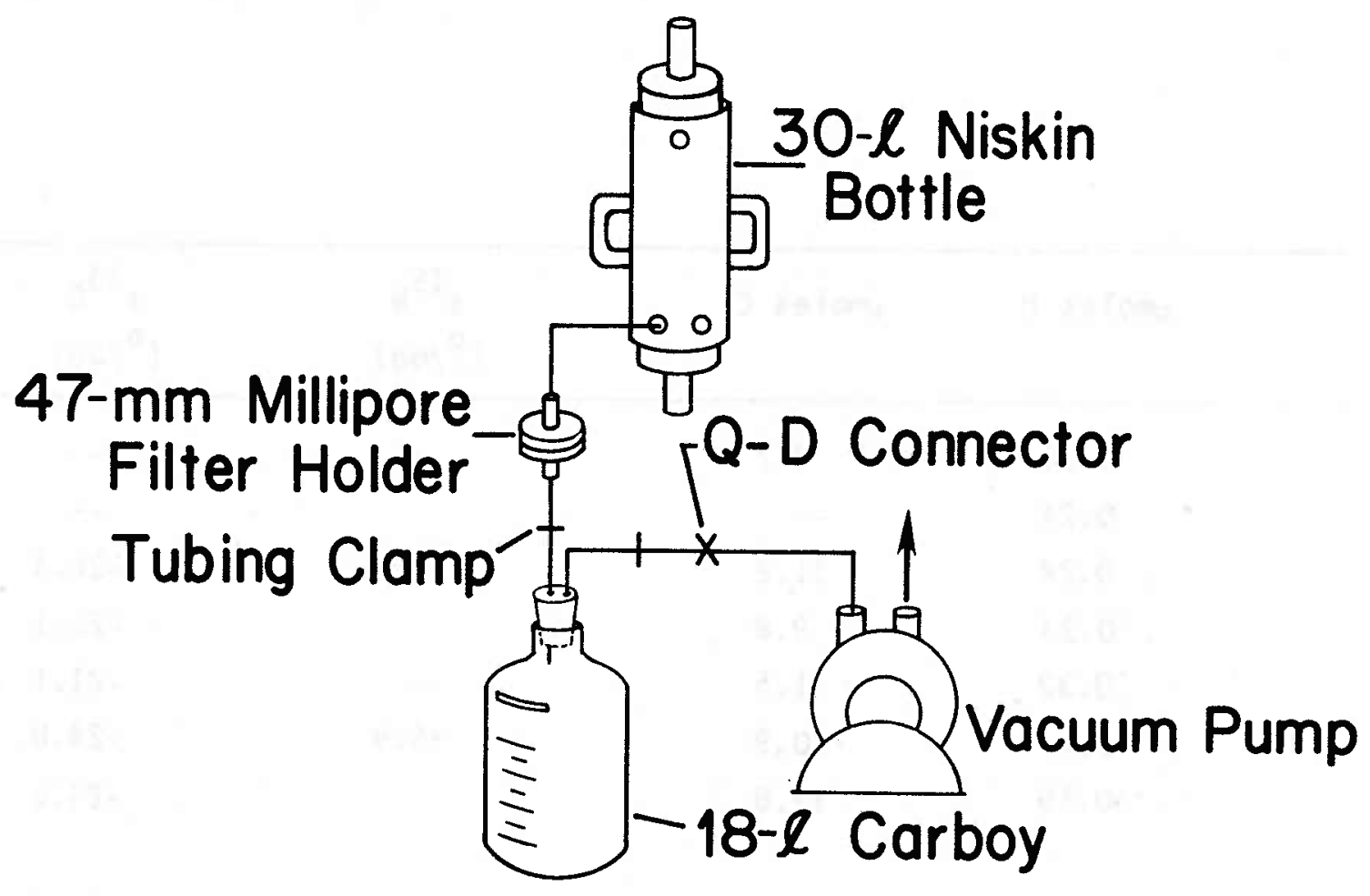


Table 2-1.

Glass-Fiber Filter $\mathrm{Bl}$ anks

\begin{tabular}{|c|c|c|c|c|}
\hline & umoles $N$ & umoles C & $\begin{array}{c}\delta^{15} \mathrm{~N} \\
\left({ }^{0} / 00\right)\end{array}$ & $\begin{array}{c}\delta^{13} c \\
\left({ }^{0} / 00\right)\end{array}$ \\
\hline & 0.39 & 8.2 & -- & -- \\
\hline & 0.24 & -- & & -- \\
\hline & 0.24 & 11.2 & +6.5 & -26.4 \\
\hline & 0.24 & 9.8 & & -25.1 \\
\hline & 0.32 & 11.5 & -- & -21.1 \\
\hline & 0.47 & 10.9 & +5.9 & -24.8 \\
\hline & 0.79 & 12.8 & & -24.6 \\
\hline Average: & 0.38 & 10.7 & +6.2 & -24.4 \\
\hline 1 S.D.: & 0.18 & 1.4 & & 1.8 \\
\hline
\end{tabular}


10.7 moles $C$ with a $\delta^{13} \mathrm{C}$ of $-24.4 \%$ oo were used to correct the concentration and isotope measurements of the filtered samples. The blanks were a significant fraction of the gas analyzed only for the POM samples collected at Station C (see CHAPTER III: POM Sampling and Analyses and APPENDIX I for the equations used to correct the $\delta$ values).

After sample collection, the filters were pumped dry before transfer into Petri dishes. Because the filters were binderless, they were fragile when wet. Forty-seven millimeter diameter circles of acid-cleaned 333- $\mu \mathrm{m}$ mesh $\mathrm{Ni}$ tex were used to prevent rupture of the glass-fiber filters during filtration as well as disintegration during transfer. The Petri dishes containing the filters were kept frozen until just prior to isotopic analysis.

The volume of seawater filtered was estimated to $\pm 0.51 i$ ters with the aid of calibration lines on the receiver carboys. When the total volume of the fil trate was 1 ess than 51 iters, 5-1 graduated cyclinders were used to measure volumes to \pm 0.1 liter.

\section{In-situ Large Volume Pumps:}

In the Gulf of Maine, battery-powered bilge pumps (see Figure 2-2) were used to pull seawater through 147-mm diameter Millipore filter holders containing Gelman A/E binderless glass-fiber filters cleaned by the method just described. The filters were supported with 147-mm diameter Nitex circles as described previously. Three sets of two filter holders each were deployed at 25, 50, and $245 \mathrm{~m}$ for 6.5 hours. Kent water meters were used to measure the volume of seawater filtered. The pumps deployed at $245 \mathrm{~m}$ were started with pressure switches, while the pumps at 25 and $50 \mathrm{~m}$ were started at the surface. The pumps were running during recovery which lasted a maximum of 90 minutes for the deepest pump. A PGR was used to monitor the distance of the pumps above the sea floor. After retrieval, the filters were pumped dry and frozen as soon as possible. 
$-53-$

Figure 2-2.

In-situ Pump Apparatus 


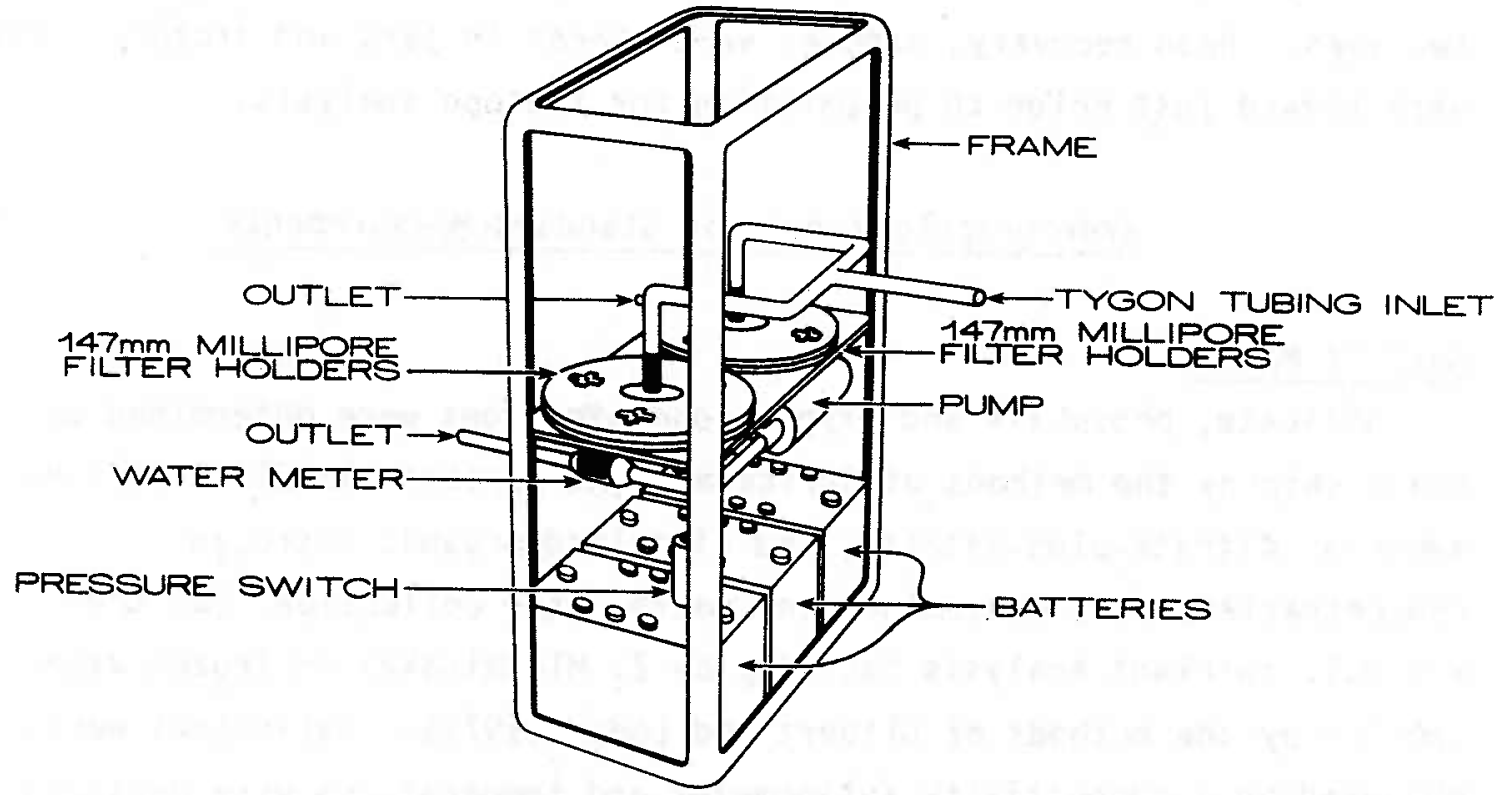

(ELECTRICAL CONNECTIONS NOT SHOWN) 
Sediment Traps:

Two samples were collected in the Peru Upwelling Area at Station SEAREX (Figure 3-2) by $D$. Repeta in moored sediment traps of the design of Staresinic (1978). Trap 12 was moored at $40 \mathrm{~m}$ and Trap 13 at $22 \mathrm{~m}$ for two days. Upon recovery, samples were stored in jars and frozen. They were thawed just prior to preparation for isotope analysis.

\section{Hydrographic and Other Standard Measurements}

\section{Gulf of Maine:}

Silicate, phosphate and oxygen concentrations were determined on board ship by the methods of Strickland and Parsons (1972). Total N, ammonia, nitrate-plus-nitrite, and dissolved organic nitrogen concentrations were determined one month after collection, (at the W.H.0.I. nutrient analysis facility by $Z$. Mlodzinska) on frozen water samples by the methods of Glibert and Loder (1977). Salinities were measured on a conductivity salinometer and temperatures were measured with reversing thermometers. Total particulate matter concentrations (TPM) were measured by the methods of Brewer et al. (1976), using 47-mm diameter Nuclepore filters in the filtration apparatus shown in Figure 2-1.

\section{Peru Upwelling Area:}

Ammonia, nitrate, nitrite, phosphate, and silicate concentrations were measured by $W$. Dickinson immediately upon sample collection by the methods of Gl ibert and Loder (1977). Total dissolved nitrogen determinations were made approximately four months after collection. At Station $\mathrm{A}$ off the coast of Peru, $\mathrm{H}_{2} \mathrm{~S}$ interfered with ammonia analyses in samples collected between 20 and $48 \mathrm{~m}$. These samples were acidified and aerated to remove hydrogen sulfide. The $\mathrm{pH}$ was adjusted before subsequent ammonia analysis. oxygen concentrations were determined by the method of Strickland and Parsons (1972).

Temperatures, salinities, and particulate matter concentrations were 
measured as described for the Gulf of Maine.

\section{I sotope Mea surements}

Sample Preparation:

Sediments were prepared for isotope analysis by suspending approximately 5 grams of homogenized sediment in distilled water in a 10-cm diameter Petri dish. The suspension was exposed to concentrated $\mathrm{HCl}$ fumes for 6 hours in order to decompose $\mathrm{CaCO}_{3}$. Excess water was evaporated by leaving the samples loosely covered with aluminum foil overnight in the fume hood. Finally the samples were dried for one to three hours at $60^{\circ} \mathrm{C}$, ground with a mortar and pestle, and stored in screw-top vials. The sediment-trap samples were prepared similarly.

The effect of the acid treatment on $\delta^{15} \mathrm{~N}$ and percent organic nitrogen was investigated. Several sediment samples from the Peru Upwelling Area were analyzed with and without the acid treatment. As shown in Table 2-2, no significant difference in percent organic nitrogen or $\delta^{15} \mathrm{~N}$ was observed.

Just prior to isotope analysis, the plankton samples were separated into size fractions using stacked Nitex sieves (see Sampling section for details). After exposure to hydrochloric acid, the samples were dried as described for the sediments.

The filters containing particulate matter and filter blanks were similarly fumed with hydrochloric acid and dried at $60^{\circ} \mathrm{C}$. Isotope analysis was performed immediately afterwards.

\section{Analysis of Carbon and Nitrogen Isotopes:}

The method developed for preparation of $\mathrm{N}_{2}$ and $\mathrm{CO}_{2}$ gas for isotope analysis closely resembles that of Macko (1981) in which organic 
Table 2-2.

Effect of Acid Treatment on Percent Nitrogen and $\delta^{15} \mathrm{~N}$

Sample

Percent Organic $N$

$\delta^{15} \mathrm{~N}(\% / 00)$

Acid

No Acid

Acid

No Acid

$\begin{array}{rr}\text { Sta. A } & 0-2 \mathrm{~cm} \\ 2-4 \mathrm{~cm} \\ 4-6 \mathrm{~cm} \\ 6-8 \mathrm{~cm} \\ 8-10 \mathrm{~cm}\end{array}$

0.26

0.31

8.2

8.2

0.28

0.25

8.0

8.5

Sta. B $\quad 0-2 \mathrm{~cm}$

0.31

0.33

8.4

8.5

0.31

0.37

8.3

8.4

0.26

0.30

8.5

7.5

$18-26 \mathrm{~cm}$

1.07

0.97

6.1

6.4

1.07

1.05

5.5

6.0 
matter is combusted with copper and copper oxide at high temperatures in a quartz tube. Ideally, the final gaseous products are water, carbon dioxide, and nitrogen gas, which are removed from the cooled tube on a vacuum 1 ine and separated according to their freezing-point differences. It is critical that the quartz tube be cooled slowly enough to ensure that the oxidation of organic carbon to $\mathrm{CO}_{2}$ and the conversion of organic nitrogen to $\mathrm{N}_{2}$ go to completion. At elevated temperatures, CuO evolves oxygen, while at lower temperatures, the $\mathrm{Cu}$ acts as a sink for free $\mathrm{O}_{2}$ and sulfur. An additional purification step, consisting of a liquid-nitrogen trap just before the mass spectrometer capillary inlet was found to be necessary in producing nitrogen pure enough for isotopic analysis. This is discussed below.

In detail:

1) Sample Preparation:

a) Sediment and Plankton:

18-cm sample tubes were constructed from $9 \mathrm{~mm} \mathrm{I.D.} \times 11 \mathrm{~mm} \mathrm{0.0.}$ quartz glass tubing with a break seal on one end. The other end was connected to a quartz $\$ 14 / 35$ male taper (see a., Figure 2-3). After checking for leaks, the tubes were precombusted at $900^{\circ} \mathrm{C}$ in a muffle furnace for 3 hours.

Using a $6 \mathrm{~mm} \mathrm{0.D.} \mathrm{funnel,} \mathrm{the} \mathrm{cooled} \mathrm{tubes} \mathrm{were} \mathrm{loaded} \mathrm{with} 1.5$ grams of Cuprox (high-purity copper used in Coleman CHN analyzers) and 3.5 grams Cu0. The Cu0 was prepared by grinding to a fine powder and precombusting at $900^{\circ} \mathrm{C}$ for 3 hours.

Weighed sediment or plankton samples were delivered into the tubes using the same size funnels. Fifty to $200 \mathrm{mg}$ of sediment and 500 to $5000 \mu \mathrm{g}$ of plankton were used to yield the approximately 5 to 10 umoles $\mathrm{N}_{2}$ needed for $\mathrm{i}$ sotopic analysis. After weighing, plankton samples were mixed with a few milligrams of CuO to ensure complete delivery through the funnels.

The connection between the taper and the quartz tube was drawn down into a 2-to-3-mm diameter capillary (see b., Figure 2-3).

The sample tubes were carefully attached to the vacuum line and 
$-59-$

Figure 2-3.

Combustion Tubes 

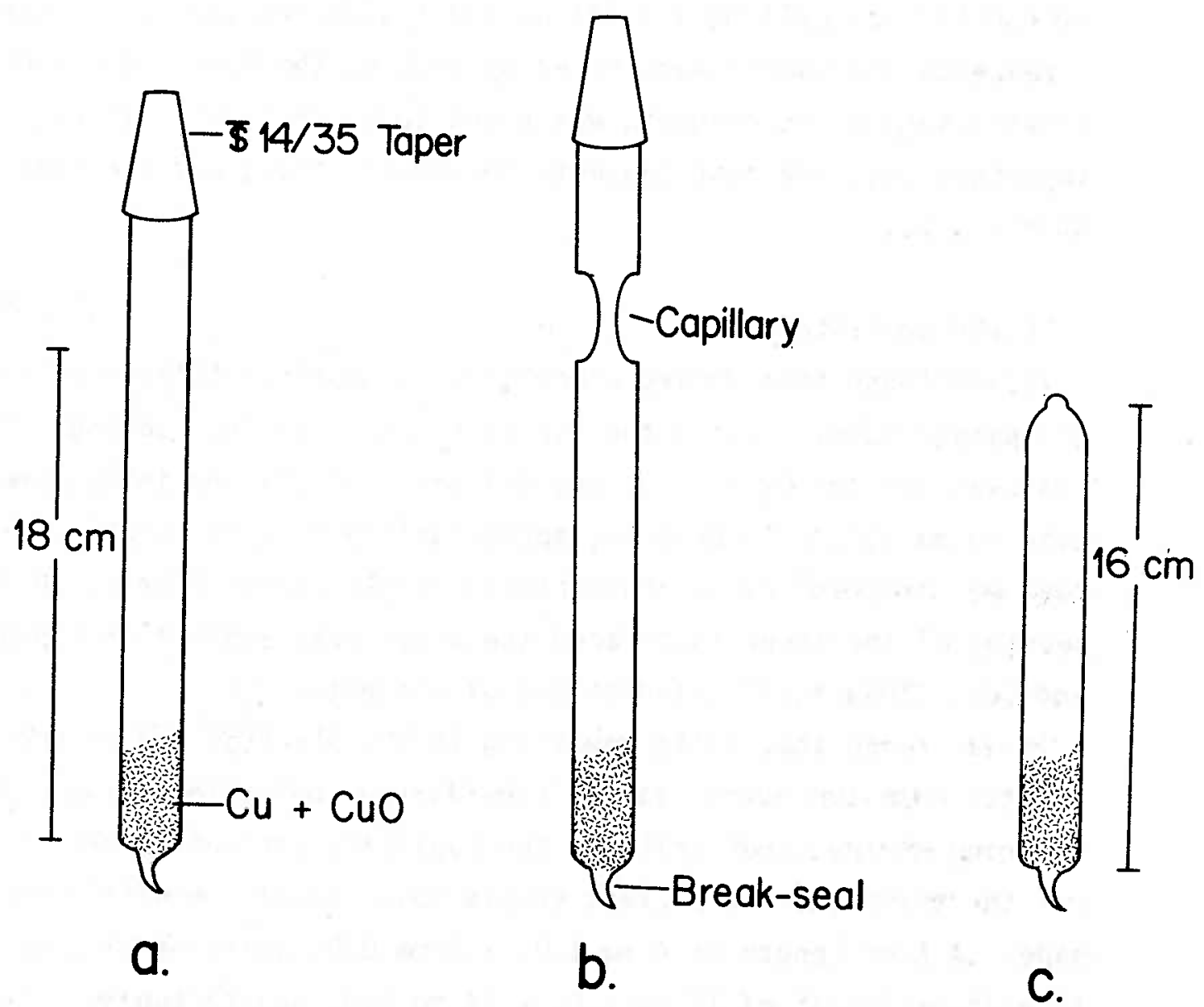
slowly evacuated to prevent sample spattering.

After evacuating overnight, the quartz tubes were sealed by heating the capillary until it collapsed. The tubes were removed from the vacuum 1 ine by pulling a point at the sealed end (see c., Figure 2-3).

Reagents and sample were mixed by shaking the tube. Close contact between sample and reagents was found to be critical. It was also important that the tube contents be spread throughout the length of the quartz tube.

\section{b) POM on Filters:}

It was found that during combustion glass-fiber filters melted onto the sample tube, causing the quartz to crack during cooling. Sample loss was avoided by rolling the slightly damp filter into a precombusted tube ( $8 \mathrm{~mm}$ I.D. $\times 10 \mathrm{~mm} \mathrm{O.D.,} \mathrm{approximately} 5 \mathrm{~cm}$ in length). The inner tube was dropped into a precombusted larger sample tube so that the opening of the inner tube faced the break seal and sat on top of the Cu and cuo. This facilitated mixing of reagents.

It was found that salts remaining in the plankton and on the filters reacted with the quartz sample tube during combustion, al so causing cracking at the break seal and the capillary seal-off where the glass was the thinnest. To prevent sample 1oss, several modifications were made. A $5-\mathrm{cm}$ length of $4 \mathrm{~mm} \mathrm{I.D.} \times 6 \mathrm{~mm} \mathrm{0.D.} \mathrm{quartz} \mathrm{tubing} \mathrm{was} \mathrm{attached}$ to a $26-\mathrm{cm} 1$ ength of $12 \mathrm{~mm} \mathrm{I.D.} \times 14 \mathrm{~mm} \mathrm{0.D.} \mathrm{quartz} \mathrm{tubing.} \mathrm{The}$ "1ong-neck" tube was precombusted at $900^{\circ} \mathrm{C}$ for 3 hours and then loaded with reagent and the filter (inside the small quartz sleeve)

(Figure 2-4a). Instead of pulling down a capillary for sealing the tube off under vacuum, a very thick-walled capillary was made by collapsing the $12 \mathrm{~mm} \mathrm{I.D.} \times 14 \mathrm{~mm} \mathrm{O.D.} \mathrm{tubing} \mathrm{down} \mathrm{to} 3 \mathrm{~mm}$ in diameter. A size 15 Ace-Thred connector was used to attach the loaded sample tube to the glass 1 ine (Figure 2-4b). After evacuating overnight, the sample tubes were removed from the vacuum line by carefully sealing them off with a gas-oxygen torch using an 0X-5 nozzle (Figure 2-4c).

With these precautions about half of the POM samples were successfully 
$-62-$

Figure 2-4.

"Long-Neck" Combustion Tubes 


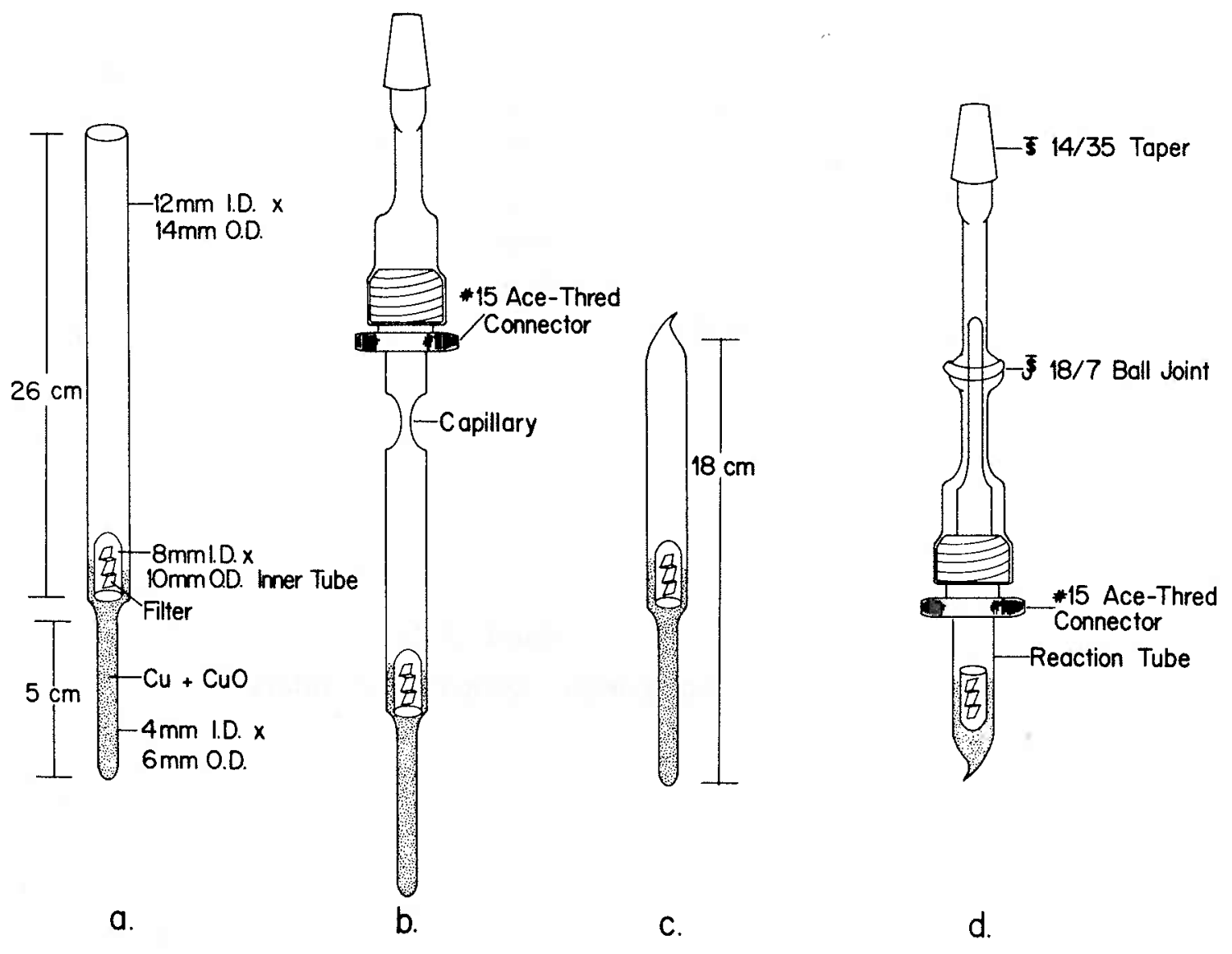


analyzed. The amount of salt in the other half of the samples was large enough to cause the "long-neck" tubes to crack during combustion. Further modifications were made to insure against sample loss. They are described in Appendix I.

\section{2) Combustion:}

A set of 5 tubes was placed in a nichrome-wire rack in a "Blue $M "$ muffle furnace. The oven was heated to $900^{\circ} \mathrm{C}$ and the samples were combusted for 1 hour at this temperature. The temperature was then decreased from 900 to $450^{\circ} \mathrm{C}$ by turning down the controller by approximately $37^{\circ} \mathrm{C}$ every half hour. The oven was then turned of and the samples allowed to cool overnight with the oven door closed.

\section{3) Separation of Gases:}

a) Break-seal Combustion Tubes:

The sample tube was loaded into a larger Pyrex tube ("cracker") so that the sample tube nested on top of a 2-cm length of $9 \mathrm{~mm}$ I.D.X $11 \mathrm{~mm}$ 0.D.tubing (see Figure 2-5a). A glass-enclosed steel bar was carefully placed on top of the sample tube's break seal. The cracker was then connected to the vacuum line using an adapter fitted with two $\$ 14 / 35$ ground glass tapers. After evacuating the vacuum 1 ine (Figure 2-5) and isolating the "cracker"(a) from the vacuum pump, the break seal was broken by lifting and dropping the steel bar with a magnet held on the outside of the "cracker". A Dewar of liquid nitrogen(b) was put under the cracker and the sample frozen for 15 minutes. The uncondensed gas, i.e. nitrogen, was admitted into a liquid-nitrogen cooled coil trap(c) for 10 minutes before removal via a 250-ml Toepler pump(d) into a calibrated volume(e) (approximately $16 \mathrm{ml}$ ). After measuring the temperature and difference in height between the $\mathrm{Hg}$ column in the inlet and outlet of the toepler pump (f), the nitrogen sample was pushed completely into a small sample tube(g) by raising the mercury column up to the sample-tube stopcock.

Meanwhile the liquid nitrogen traps were lowered and the 
$-65-$

Figure 2-5.

High-Vacuum Separation Line 


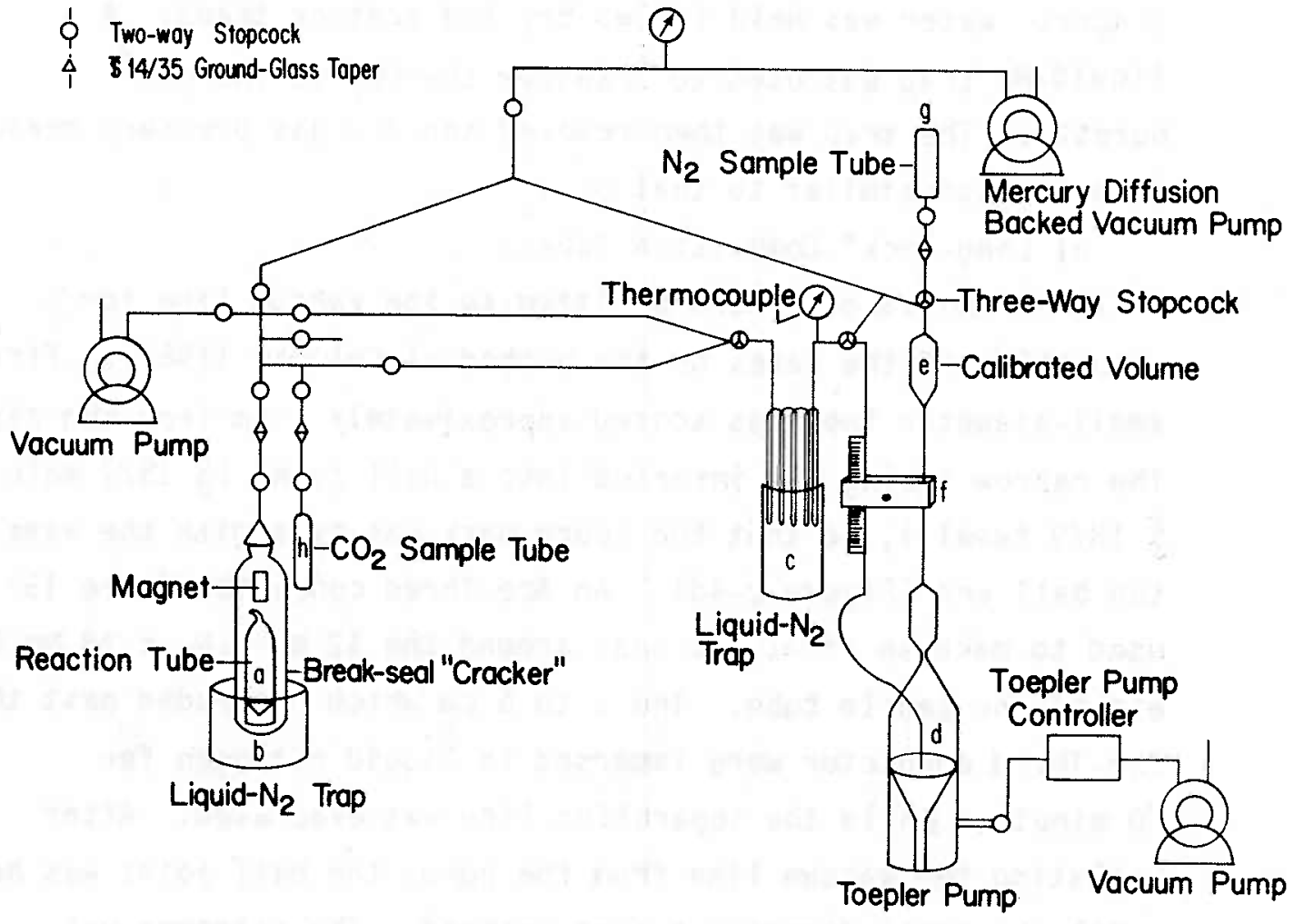


condensates (water and $\mathrm{CO}_{2}$ ) transferred into a sample tube $(\mathrm{h})$ located next to the "cracker" assembly. The condensates were separated and the amount of $\mathrm{CO}_{2}$ was measured on another vacuum 1 ine equipped with a gas burette fitted with a 1 iquid- $N_{2}$ cold finger. Water was held in two dry-ice acetone traps. A 1iquid- $\mathrm{N}_{2}$ trap was used to transfer the $\mathrm{CO}_{2}$ to the gas burette. The trap was then removed and the gas pressure measured in a fashion similar to that of $\mathrm{N}_{2}$.

b) "Long-Neck" Combustion Tubes:

The filter samples were admitted to the vaccum line for separation of the gases by the method of Coleman (1981). First the small-diameter tube was scored approximately $1 \mathrm{~cm}$ from the tip. The narrow tubing was inserted into a ball joint ( $\$ 18 / 7$ male and $\$ 18 / 9$ female), so that the score mark was even with the base of the ball end (Figure 2-4d). An Ace-Thred connector (size 15), was used to make an air-tight seal around the $12 \mathrm{~mm} \mathrm{I.D.} \times 14 \mathrm{~mm} \mathrm{0.D.}$ end of the sample tube. The 5 to $6 \mathrm{~cm}$ which protruded past the Ace-Thred connector were immersed in liquid nitrogen for 10 minutes, while the separation line was evacuated. After isolating the vacuum 1 ine from the pump, the ball joint was bent until the small-diameter tubing snapped. The nitrogen was transfered to the calibrated volume using the toepler pump and the carbon dioxide collected by a procedure identical to that used with the break seals.

Several thiourea standards were run using these modifications to check for reproducibility and intercomparison with the break seal method. Although the results (Table 2-3) from the "long-neck" tubes appeared to be more variable than those from the break-seals, the variability was small ( 1 S.D. $\left.=0.16^{\circ} / 00\right)$.

\section{4)Final Purification Step:}

Before admitting the nitrogen samples to the capillary inlet on the mass spectrometer, another liquid-nitrogen trap was found to be necessary. Without this trap, $\delta^{15} \mathrm{~N}$ values were extremely 
Table 2-3.

Analyses of Thiourea by Break Seal and "Long-Neck" Methods

Percent* Percent

Yield N Yield C

$\mathrm{C} / \mathrm{N}$

$\delta 15 \mathrm{~N}$

$\delta^{13} \mathrm{C}$

$(0 / 00)$

$(0 / 00)$

\section{Break seals}

$\begin{array}{lrrrr}99.5 & 107.5 & 0.54 & -1.32 & -22.58 \\ 100.4 & 111.1 & 0.56 & -1.34 & -22.65 \\ 99.9 & 108.8 & 0.55 & -1.36 & -22.63 \\ 100.1 & 109.0 & 0.55 & -1.32 & -22.56 \\ & & & & \\ 100.0 & 109.1 & 0.55 & -1.35 & -22.61 \\ .: 0.3 & 1.3 & 0.01 & 0.02 & 0.04\end{array}$

"Long-Necks"

$\begin{array}{lllll}99.3 & 109.5 & 0.55 & -1.16 & -22.75 \\ 102.1 & 112.7 & 0.55 & -1.28 & -22.63 \\ 98.4 & 109.1 & 0.55 & -1.23 & -22.74 \\ 99.4 & 111.8 & 0.55 & -0.87 & -23.74\end{array}$

Ave: $99.8 \quad 110.8$

1 S.D.:1.4 1.5

0.55

$-1.14$

$-22.72$

0.01

0.16

0.05

DeNiro: $99.1 \quad 99.5$

$-0.9$

$-22.8$

* $\frac{\mu \text { moles } N}{(\mu g \text { thiourea } / 76.12 \mu g / \mu \text { mole }) \times 2} \times 100$


variable. With the trap, $\delta 15_{\mathrm{N}}$ values were reproducible to $\pm 0.10 \% 0$ for sediment, air, and thiourea samples. A small dimple in the top of the nitrogen sample tube served as a cold finger (Figure 2-6). Ten minutes of freezing was sufficient. Mass scans showed $a>50$ percent decrease in the height of the $m / e=44$ peak when the trap was used (Table 2-4), suggesting that in the unfrozen samples small amounts of $\mathrm{CO}_{2}$ gave rise to $\mathrm{CO}$ fragments in the mass spectrometer which interfered with the precise measurement of the $29 / 28$ mass ratio.

5) Isotope Analyses:

Isotope analyses were made on a Nuclide isotope ratio mass spectrometer equipped with an integrating ratiometer. ${ }^{13} \mathrm{C}$ measurements were made by the methods of Craig (1957) using NBS-21 and another graphite as the working standards. The nitrogen isotope analyses were done in a similar fashion. Nitrogen gas pressure equivalent to four centimeters of $\mathrm{Hg}$ yielded an ion beam of 20 to $23 \mathrm{~V}$ as measured by the electrometer amplifier (Nuclide Model EA-4, equipped with a $2 \times 10^{11}$ ohm resistor). For sample sizes ranging from 0.5 to 5 umoles $\mathrm{N}_{2}$, the sample pressure before the capillary leak was maintained at $4 \mathrm{~cm}$ of $\mathrm{Hg}$ by slowly raising the height of the $\mathrm{Hg}$ column under the sample gas in order to compensate for sample consumption during analysis. A stream of nitrogen gas controlled by a variable leak was used for this purpose (see Figure 2-7). The small ion beam $\left(15_{N} 14_{N}\right.$ ) was measured with a vibrating-reed electrometer (Applied Physics Model Cary-31, equipped with a $1 \times 10^{10}$ ohm resistor) on the $100-\mathrm{mV}$ scale. The ratio of the small beam over the large beam $\left(14_{N} 14 N\right)$ was integrated for 1400 volt-seconds ( 70 seconds). Runs of the sample were alternated with similar runs of the standard gas (Linde ultra-high purity tank nitrogen). A 20-second delay after switching was necessary to allow for complete gas exchange. The length of the switchover delay was determined by monitoring a stripchart output of the ratio of the two ion beams, 
$-70-$

Figure 2-6.

Nitrogen Gas Sample Tube 


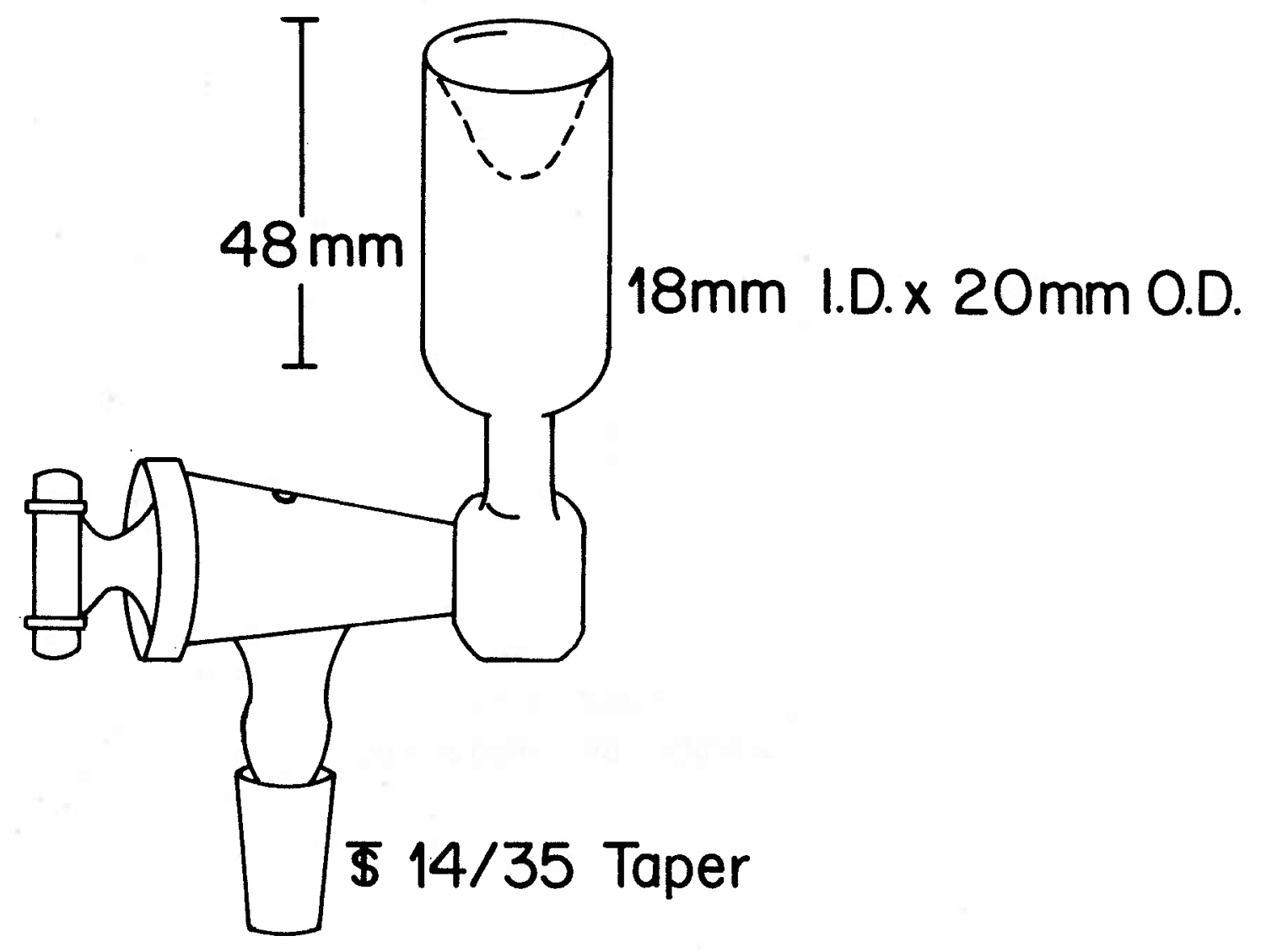


Table 2-4.

Molecular Ion Voltages

(as measured by the Cary-31 Vibrating Reed Electrometer)

$\begin{array}{lrrrrl} & & m / e(V) & & \delta^{15} \mathrm{~N} \\ \text { Sample } & 44 & 32 & 30 & 29 & (\% / 00)\end{array}$

P1 ankton 1:

\begin{tabular}{|c|c|c|c|c|}
\hline $\begin{array}{l}\text { No Liquid-N } 2 \text { trap } \\
\text { Liquid-N2 trap }\end{array}$ & $\begin{array}{l}0.62 \\
0.24\end{array}$ & $\begin{array}{l}0.79 \\
0.71\end{array}$ & $\begin{array}{l}0.19 \\
0.19\end{array}$ & $\begin{array}{l}3.6 \\
3.6\end{array}$ \\
\hline
\end{tabular}

Plankton 2:

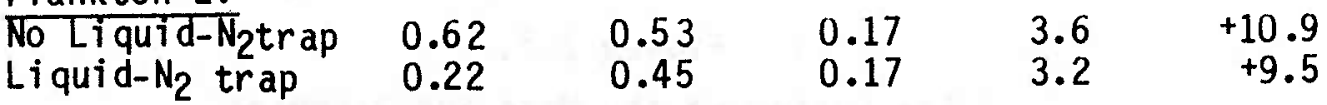

Sediment 1:

$\begin{array}{llllll}\text { No Liquid-N2trap } & 0.60 & 0.60 & 0.16 & 3.6 & +7.6 \\ \text { Liquid-N2 trap } & 0.21 & 0.49 & 0.16 & 3.6 & +6.6\end{array}$

Sediment 2:

\begin{tabular}{|c|c|c|c|c|}
\hline $\begin{array}{l}\text { No Liquid-N } 2 \text { trap } \\
\text { Li quid- } N_{2} \text { trap }\end{array}$ & $\begin{array}{l}0.60 \\
0.20\end{array}$ & $\begin{array}{l}0.36 \\
0.33\end{array}$ & $\begin{array}{l}0.15 \\
0.15\end{array}$ & $\begin{array}{l}3.2 \\
3.2\end{array}$ \\
\hline
\end{tabular}

Sediment 3:

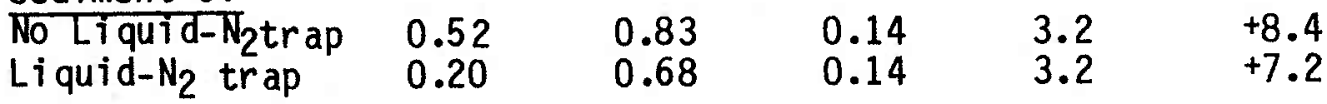

Background (No samples):

$\begin{array}{llll}0.14 & 0.25 & 0.07 & 0.03\end{array}$

U1 tra-high Purity $\mathrm{N}_{2}$ :
0.22
0.22
0.12
3.2
$+0.1$ 
$-73-$

Figure 2-7.

Inlet System of the Mass Spectrometer 


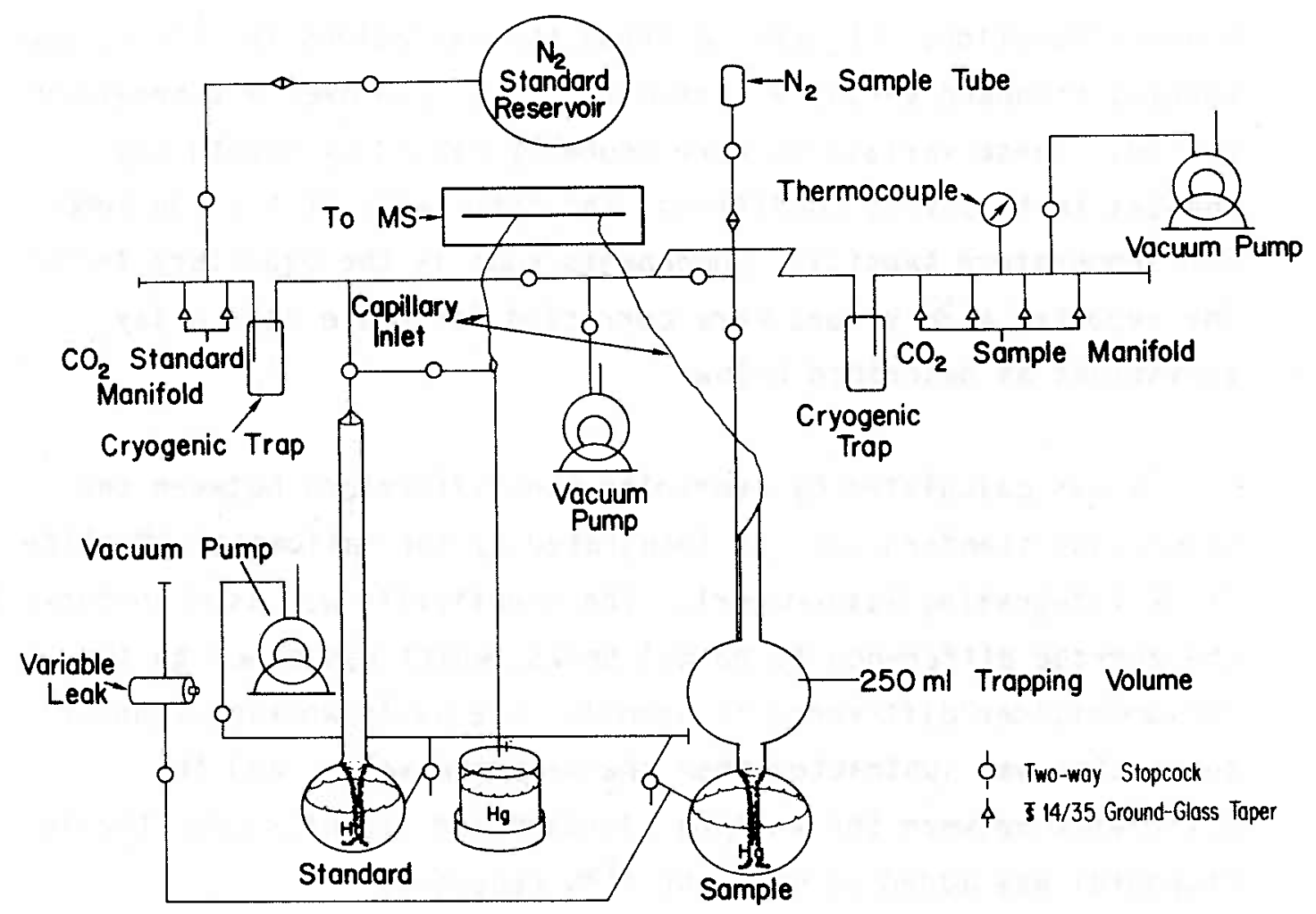


which stabilized within 20 seconds after the switchover. This cycle was repeated three times and a sensitivity check was then made. Each day, the working standard, tank nitrogen, was run against a separate tank-nitrogen sample for day-to-day intercalibration. Figure $2-8$ shows the variations in $\delta^{15} \mathrm{~N}$ of the working standard versus a tank-nitrogen sample over a three-year period. These variations were probably caused by day-to-day changes in focussing conditions, the efficiency of the ion pumps, and temperature sensitive components such as the capillary inlets. The reported $\delta^{15} \mathrm{~N}$ values were corrected for these day-to-day variations as described below.

${ }^{15} \mathrm{~N}$ was calculated by averaging the differences between the sample and standard runs as integrated by the ratiometer (Nuclide IR-2A Integrating Ratiometer). The sensitivity was used to convert the average difference to permil units, which was added to the decade divider difference in pernil. The daily working-standard correction was subtracted from the measured value, and the difference between the working standard and air nitrogen (the NBS standard) was added to give the $\delta^{15} \mathrm{~N}$ reported.

\section{5) Blanks:}

Reaction tubes containing only $\mathrm{Cu}$ and $\mathrm{Cu} 0$ were treated as though they contained a sample. The results of these reaction-tube blank runs are shown in Table 2-5. The nitrogen from three blanks was combined to yield enough gas for isotopic measurement. Since most of the plankton, sediment, and sediment-trap samples generated at least $10 \mu$ moles of $N$, the effect of the reaction-tube blank on the $\delta$ values was negligible. For the POM samples, the filters often comprised a significant portion of the gas. See Chapter III: POM Sampling and Analysis and Appendix I for the equations used to correct the $\delta$ values. 
Figure 2-8.

$\delta^{15} \mathrm{~N}$ of Tank Nitrogen used as Working Standard 


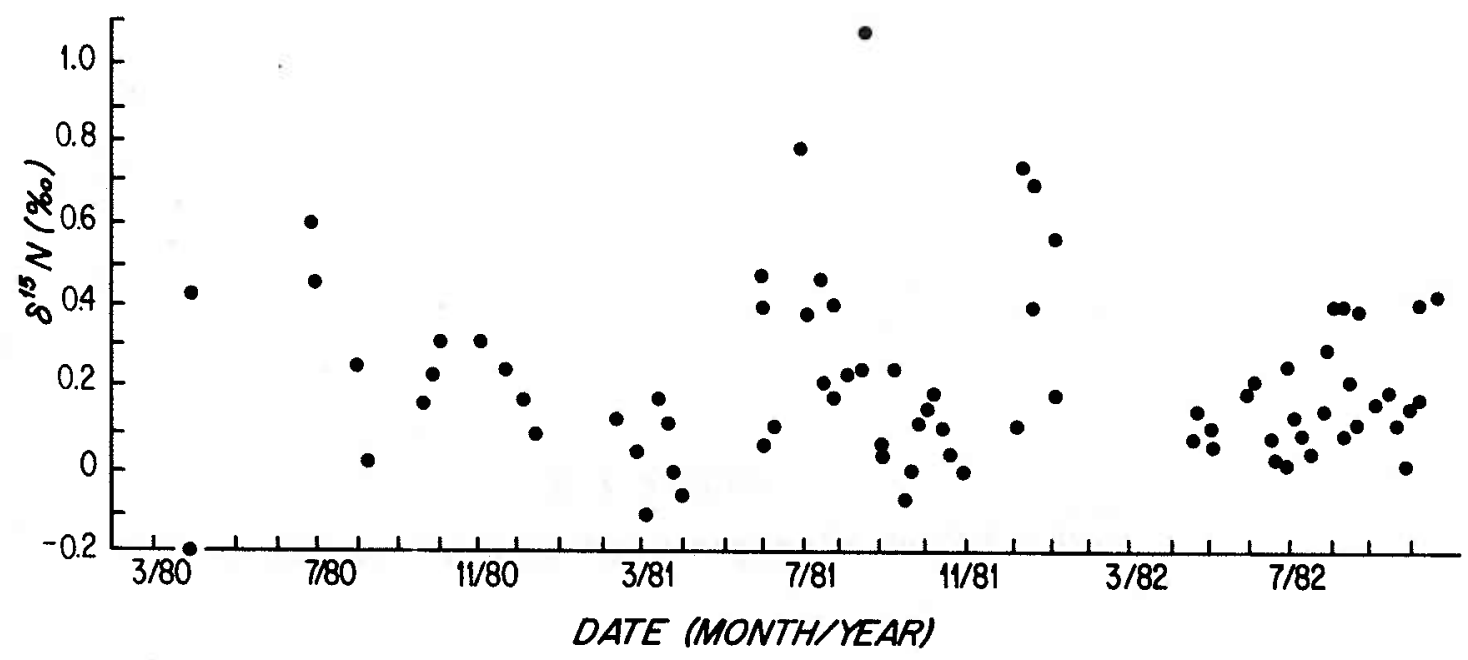


Table 2-5.

Sample-Tube Blanks

\begin{tabular}{ccccc} 
umoles $N$ & umoles $\mathrm{C}$ & $\mathrm{C} / \mathrm{N}$ & $\begin{array}{c}\delta^{15} \mathrm{~N} \\
(\% / 00)\end{array}$ & $\begin{array}{c}{ }^{13} \mathrm{C} \\
(\% / 00)\end{array}$ \\
\hline 0.31 & 1.93 & 6.2 & $T$ & -20.10 \\
0.24 & 2.20 & 9.2 & +9.81 & -20.20 \\
0.24 & 1.27 & 5.3 & -1 & -18.64 \\
undetectable & 1.82 & -- & --24.35 & -22.80 \\
0.27 & 1.54 & 5.7 & - & \\
\hline
\end{tabular}


6) Standards:

The NBS i sotope standard for $\delta^{15_{N}}$, a ir nitrogen, was prepared by degassing a sample tube containing $\mathrm{Cu}$ and CuO and having a mid-section already constricted into a capillary (see b., Figure 2-3). An aliquot of local air yielding approximately 10 umoles $\mathrm{N}_{2}$ per tube was admitted to the vacuum 1 ine. The sample tube was detached from the vacuum manifold as for the organic-matter samples. The results of the analyses of nine air samples run on the same day are shown in Table 2-6.

7) Precision and Accuracy:

Several tests were made to check the reproducibility and accuracy of the isotopic and gas-yield measurements. Over a one-year period, aliquots of thiourea (from the 1 ab of M. DeNiro, UCLA) were analyzed as described above. The results are shown in Table 2-7. The average yield of nitrogen was 99.3 percent and of carbon 109.6 percent of the amount predicted from the micrograms of thiourea combusted. Possible impurities in the thiourea were suggested by the results of the CHN analysis: 98.4 percent organic nitrogen and 104.5 percent organic carbon. The $\delta^{13} \mathrm{C}$ values produced by the quartz tube combustion method differed from those produced by the Craig combustion method by less than $0.1 \%$.

The $\delta 15 \mathrm{~N}$ results were 1 ower than those of $M$. DeNiro by $0.6 \%$. Local air is used as the primary isotope standard by nitrogen isotope geochemists. If the $\delta^{15} \mathrm{~N}$ of air in Woods Hole is different from that of UCLA, an offset in the $\delta^{15} \mathrm{~N}$ of a 11 samples would result. Though Junk and Svec (1958) and other workers have shown that the $\delta^{15} \mathrm{~N}$ of air from several locations was constant (see the review by Wlotzka, 1972), Cline (1973) reported that air from Los Angeles varied by $\pm 0.70 \%$ within a two-month period. Sweeney et a1. (1978) also reported differences in $\delta 15 \mathrm{~N}$ (up to $1.330 \%$ ) of air nitrogen collected from various locations around the world, though these results were interpreted as resulting from inadequate removal of oxygen from the nitrogen 
Table 2-6.

$\delta^{15} \mathrm{~N}$ of Air Nitrogen

Sample Number

$\delta 15$ *

$(0 / 00)$

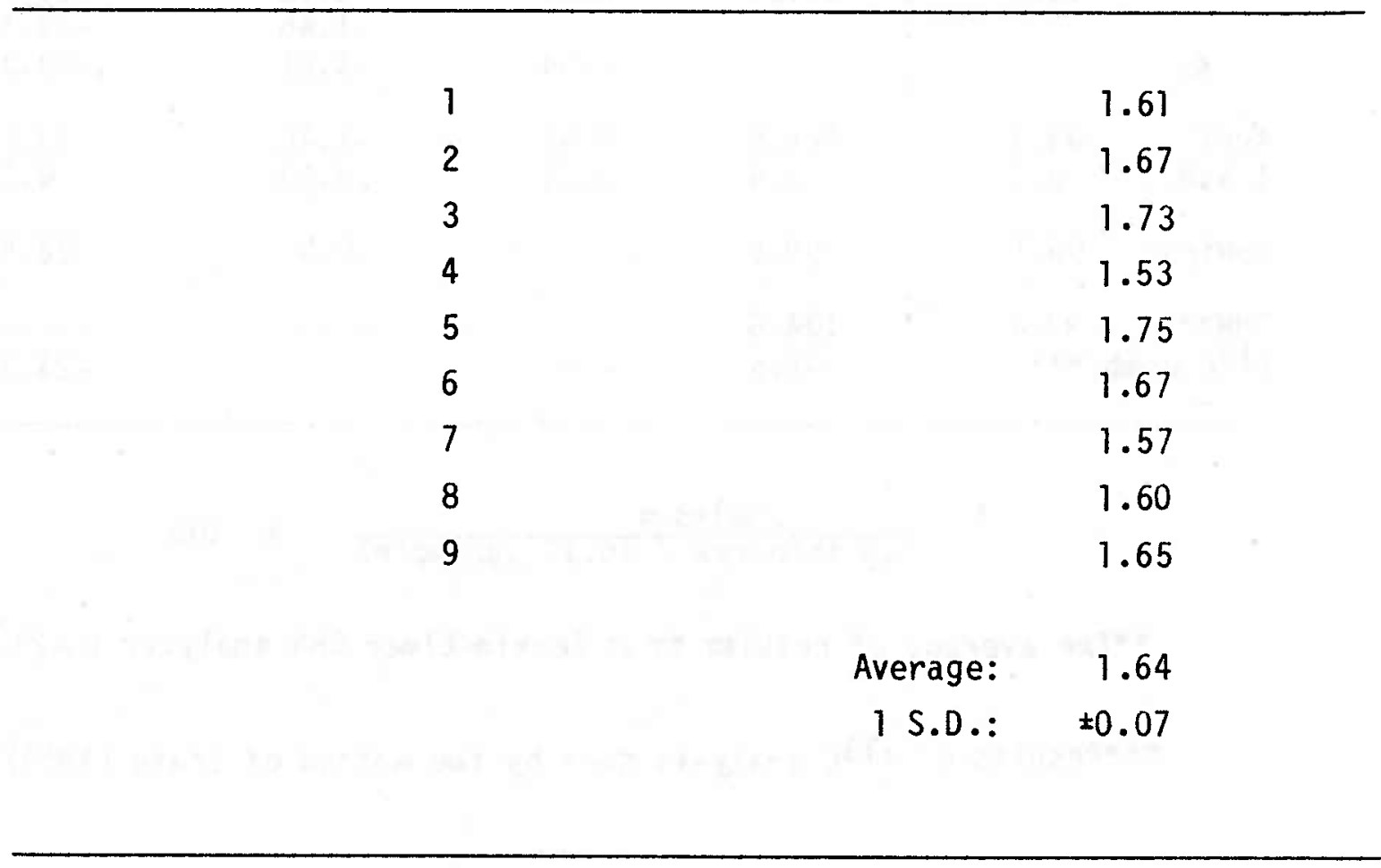

( ${ }_{\text {with }}$ respect to Tank $\mathrm{N}_{2}$ ) 
Table 2-7.

Analyses of Thiourea

\begin{tabular}{|c|c|c|c|c|c|}
\hline & $\begin{array}{l}\text { Percent* } \\
\text { Yield N }\end{array}$ & $\begin{array}{l}\text { Percent } \\
\text { Yield C }\end{array}$ & $\mathrm{C} / \mathrm{N}$ & $\begin{array}{c}\delta^{15} \mathrm{~N} \\
(\% / 00)\end{array}$ & $\begin{array}{c}\delta^{13} \mathrm{C} \\
\left({ }^{0} / 00\right)\end{array}$ \\
\hline & $\begin{array}{r}98.2 \\
99.5 \\
98.9 \\
100.3 \\
98.9 \\
99.7\end{array}$ & $\begin{array}{l}111.5 \\
108.7 \\
110.0 \\
107.9 \\
106.1 \\
113.5\end{array}$ & $\begin{array}{l}0.57 \\
0.55 \\
0.56 \\
0.54 \\
0.54 \\
0.57 \\
0.54\end{array}$ & $\begin{array}{l}-1.36 \\
-1.35 \\
-1.38 \\
-1.28 \\
-1.64 \\
-1.63 \\
-1.46 \\
-1.61\end{array}$ & $\begin{array}{l}-22.8 \\
-22.8 \\
-22.9 \\
-23.0 \\
-23.2 \\
-23.2 \\
-22.9 \\
-23.3\end{array}$ \\
\hline $\begin{array}{l}\text { Ave: } \\
1 \text { S.D.: }\end{array}$ & $\begin{array}{r}99.3 \\
0.7\end{array}$ & $\begin{array}{r}109.6 \\
2.4\end{array}$ & $\begin{array}{l}0.56 \\
0.01\end{array}$ & $\begin{array}{r}-1.46 \\
0.13\end{array}$ & $\begin{array}{r}-23.0 \\
0.2\end{array}$ \\
\hline DeNiro: & 99.1 & 99.5 & & -0.9 & -22.8 \\
\hline $\begin{array}{l}\text { CHN**: } \\
{ }_{\delta}^{13} \mathrm{C} \text { comb. }\end{array}$ & .98 .4 & $\begin{array}{r}104.5 \\
91.6\end{array}$ & -- & --- & -23.0 \\
\hline
\end{tabular}

$\star$ $\frac{\mu m o l e s ~}{} \frac{1}{(\mu g \text { thiourea } / 76.12 \mu \mathrm{g} / \mu \mathrm{mole}} \times 100$ $\star \star *$ The average of results from Perkin-Elmer CHN analyzer $(n=2)$. $\star \star \star R e s u l t s$ of ${ }^{13} \mathrm{C}$ analysis dorie by the method of Craig (1953). 
prior to isotope analysis. As described in the Introduction, the reservoir of $\mathrm{N}_{2}$ in the atmosphere is very large. Thus, it is unlikely that its isotopic content is spatially variable. Since the atmosphere surrounding Los Angeles is heavily polluted with carbon monoxide and nitrogen oxides, it may be possible that impurities caused the 1 arge variation in $\delta^{1} 5_{\mathrm{N}}$ observed by $\mathrm{Cline}$. Al ternatively, if $\mathrm{N}_{2} 0$ had a $\delta 15 \mathrm{~N}$ value significantly different from $\mathrm{N}_{2}$, it may have caused variations in the $\delta 15 \mathrm{~N}$ of air $\mathrm{N}_{2}$, since it is reduced to $\mathrm{N}_{2}$ during the purification procedure used to remove $\mathrm{CO}_{2}$ and $\mathrm{O}_{2}$.

To investigate this intercalibration problem further, four organic-matter samples provided by M. DeNiro were analyzed. The results are shown in Table 2-8. Al so 1 isted are two synthetic organic compounds used for laboratory intercomparison: thiourea from M. DeNiro and glycine from S. Macko, which has also been analyzed by $M$. Wada. From the results of the analyses of six different kinds of organic matter, which varied over a wide range of $\delta^{15} \mathrm{~N}$, it appears that there is a marginally significant systematic difference between my results and those of DeNiro since our analytical errors are $\pm 0.10 \%$. Very close agreement was achieved with S. Macko and M. Wada.

Six aliquots of a sediment sample $(2-4 \mathrm{~cm}$ section from a core collected at $15^{\circ} \mathrm{S}$ off the coast of Perul were analyzed on different days over a one-week period to check for day-to-day variations in the analytical balances, gas burettes, and mass spectrometer (see Table 2-9). The percent organic nitrogen and carbon, and $C / N$ results were very close to values generated by a Perkin-Elmer $\mathrm{CHN}$ analyzer. The $\delta^{13} \mathrm{C}$ values produced by an independent combustion method (Craig, 1953) were $0.5 \%$ oo lower and the carbon content was 0.1 percent larger as compared to the quartz-tube combustion method.

\section{Summary:}

The reproducibility of the $\delta 15 \mathrm{~N}$ measurement was $\pm 0.130 / 00$ for 
Table 2-8.

Organic-Matter Intercalibration Experiment

\begin{tabular}{|c|c|c|c|}
\hline \multirow[t]{2}{*}{ Sample } & \multicolumn{2}{|c|}{${ }_{\delta} 15_{N}(0 / 00)$} & \multirow[b]{2}{*}{$\Delta^{*}$} \\
\hline & This Study & DeNiro & \\
\hline Artemia & +0.2 & +0.7 & -0.5 \\
\hline Caenorhabditis elegans & +5.4 & +6.1 & -0.7 \\
\hline E. Coli & +2.5 & +3.3 & -0.8 \\
\hline Dunaliella, sp. & -8.0 & -8.5 & +0.5 \\
\hline Thiourea & -1.5 & -0.9 & -0.6 \\
\hline \multirow[t]{4}{*}{ Glycine } & +2.6 & $+2.8($ Wada $)$ & -0.2 \\
\hline & & +2.7 (Macko) & -0.1 \\
\hline & & \multicolumn{2}{|c|}{ Average $\Delta:-0.3$} \\
\hline & & 1 S.D. & 0.3 \\
\hline
\end{tabular}


Table 2-9.

Analyses of Sediment from

Station SEAREX $(2-4 \mathrm{~cm})$

SEDIMENT

\begin{tabular}{|c|c|c|c|c|c|c|}
\hline & $\begin{array}{l}\text { Percent } \\
\text { Ni trogen }\end{array}$ & $\begin{array}{l}\text { Percent } \\
\text { Carbon }\end{array}$ & $C / N$ & $\begin{array}{l}\delta^{15} \mathrm{~N} \\
\left({ }^{0} / 00\right)\end{array}$ & $\begin{array}{c}\delta^{13} C \\
\left({ }^{0} / 00\right)\end{array}$ & $\mathrm{mg}$ of sample \\
\hline & $\begin{array}{l}0.199 \\
0.195 \\
0.195 \\
0.194 \\
0.190 \\
0.197\end{array}$ & $\begin{array}{l}1.51 \\
1.52 \\
1.50 \\
1.51 \\
1.49 \\
1.51\end{array}$ & $\begin{array}{l}8.9 \\
9.1 \\
9.0 \\
9.0 \\
9.2 \\
8.9\end{array}$ & $\begin{array}{c}6.37 \\
6.37 \\
6.54 \\
6.65 \\
-- \\
6.42\end{array}$ & $\begin{array}{l}-21.38 \\
-21.30 \\
-21.34 \\
-21.29 \\
-21.20 \\
-21.25\end{array}$ & $\begin{array}{l}209.55 \\
204.01 \\
205.05 \\
202.38 \\
203.88 \\
198.98\end{array}$ \\
\hline $\begin{array}{l}\text { Ave: } \\
\text { I S.D.: }\end{array}$ & $\begin{array}{l}0.195 \\
0.003\end{array}$ & $\begin{array}{l}1.51 \\
0.01\end{array}$ & $\begin{array}{l}9.0 \\
0.1\end{array}$ & $\begin{array}{l}6.47 \\
0.11\end{array}$ & $\begin{array}{r}-21.29 \\
0.06\end{array}$ & \\
\hline $\begin{array}{l}\text { CHN*: } \\
\delta^{13} \text { C com }\end{array}$ & $\mathrm{mb}^{0.21}$ & $\begin{array}{l}1.52 \\
1.65\end{array}$ & $\begin{array}{c}8.7 \\
--\end{array}$ & -- & $-\overline{-21.77}$ & $\begin{array}{r}20.00 \\
120.00\end{array}$ \\
\hline
\end{tabular}

*The average of 6 analyses from a Perkin-Elmer CHN analyzer

$* *$ The average of two analyses from $\delta^{13} \mathrm{C}$ analysis by the method of Craig (1953) 
thiourea $(n=8), \pm 0.11 \%$ for sediment $(n=6)$, and $\pm 0.070 / 00$ for air $(n=9)$; for $\delta^{13} \mathrm{C}$ the reproducibility was $\pm 0.18 \% / 00$ for thiourea and $\pm 0.06 \%$ for sediment. Intercalibration experiments showed a close agreement $\left( \pm 0.3^{0} / 00\right)$ between 1 abs. There was also agreement with ${ }^{13} \mathrm{C}$ values produced by an independent method. The reproducibility of the quartz-tube combustion method for percent organic nitrogen and carbon, and $C / N$ ratios was better than that of a Perkin-Elmer CHN analyzer, although the average organic contents generated by the two independent methods agreed closely. The percent organic nitrogen and carbon results from analyses of a yield standard, thiourea, indicated that some carbon impurities were present in the thiourea. Drawbacks to this method are the amount of time required (approximately 7 samples were processed in one week) and the requirement that the sample be in dried form.

Several other methods are used by i sotope geochemists for the preparation of $\mathrm{N}_{2}$ for $\delta 15 \mathrm{~N}$ analysis. Repeated attempts were made to reproduce some of these methods without success. The method developed for this work, though time-consuming, yielded the most reproducible isotope, percent organic nitrogen and carbon values. Using this method, a wide range of organic matter can be analyzed and in the case of marine samples, sea-salt interference can be overcome. With the mass spectrometer inlet design and variable leak shown in Figure 2-7, samples as small as 0.4 umoles $\mathrm{N}_{2}$ can be analyzed. 
CHAPTER 3

PERU UPWELLING AREA

\section{Introduction}

Along the coast of Peru, the prevailing southeasterly trade winds cause Ekman transport of surface waters away from the coast. The resulting divergence causes vigorous upwelling of cold, nutrient-rich waters during the southern hemisphere winter. South of $15^{\circ} \mathrm{S}$, the upwelling water is derived from Subantarctic water brought north by the Peru Coastal Current, while between 4 and $14^{\circ} \mathrm{S}$, the source of the upwelled water is thought to be the cold $\left(7\right.$ to $\left.17^{\circ} \mathrm{C}\right)$, oxygen-deficient Equatorial Subsurface waters brought south by the onshore Peru Undercurrent and the offshore Peru Countercurrent.

Along the coast, waters are upwelled from depths of no more than $100 \mathrm{~m}$. Three centers of intense upwelling are found along the coast of Peru, located at $5^{\circ} \mathrm{S}, 11$ to $12^{\circ} \mathrm{S}$ (during the summer months), and at $15^{\circ} \mathrm{S}$ (Maeda and Ki shimoto, 1970). The upwelled waters are characterized by low temperatures $\left(15\right.$ to $\left.17^{\circ} \mathrm{C}\right)$ and high nutrient concentrations $\left(\sim 25 \mu \mathrm{M} \mathrm{SiO}{ }_{2}, \sim 2 \mu \mathrm{M} \mathrm{PO}_{4}\right.$, and $\left.\sim 25 \mu \mathrm{M} \mathrm{N} 0_{3}^{-}\right)$, which support rates of primary production ( 1 to $3 \mathrm{~g} \mathrm{C} \mathrm{m}^{-2} \mathrm{~d}^{-1}$ ) ten times higher than average daily rates $\left(0.1\right.$ to $0.2 \mathrm{~g} \mathrm{C} \mathrm{m}^{-2} \mathrm{~d}^{-1}$ ) found in open ocean waters (Zuta and Guillén, 1970). The distribution of primary productivity is shown in Figure 3-1.

A 1 arge standing crop of phy toplankton supports 1 arge populations of zooplankton and fish, primarily anchovies, making the Peru Upwelling Area the most productive area in the world's oceans. Though its area comprises only 0.02 percent of the marine environment, it produces 15 to 20 percent of the global marine fish industry catch (Sorokin, 1978). This enormous amount of biological productivity produces a large flux of POM to the coastal sediments. Free-floating sediment traps have been employed to measure the vertical flux of POC at $15^{\circ} \mathrm{S}$. In 1978 , 
Figure 3-1.

The Distribution of Primary Productivity in the Peru Upwelling Area $\left(\mathrm{g} \mathrm{m}^{-2} \mathrm{~d}^{-1}\right)$, from Zuta and Guillén (1970) 


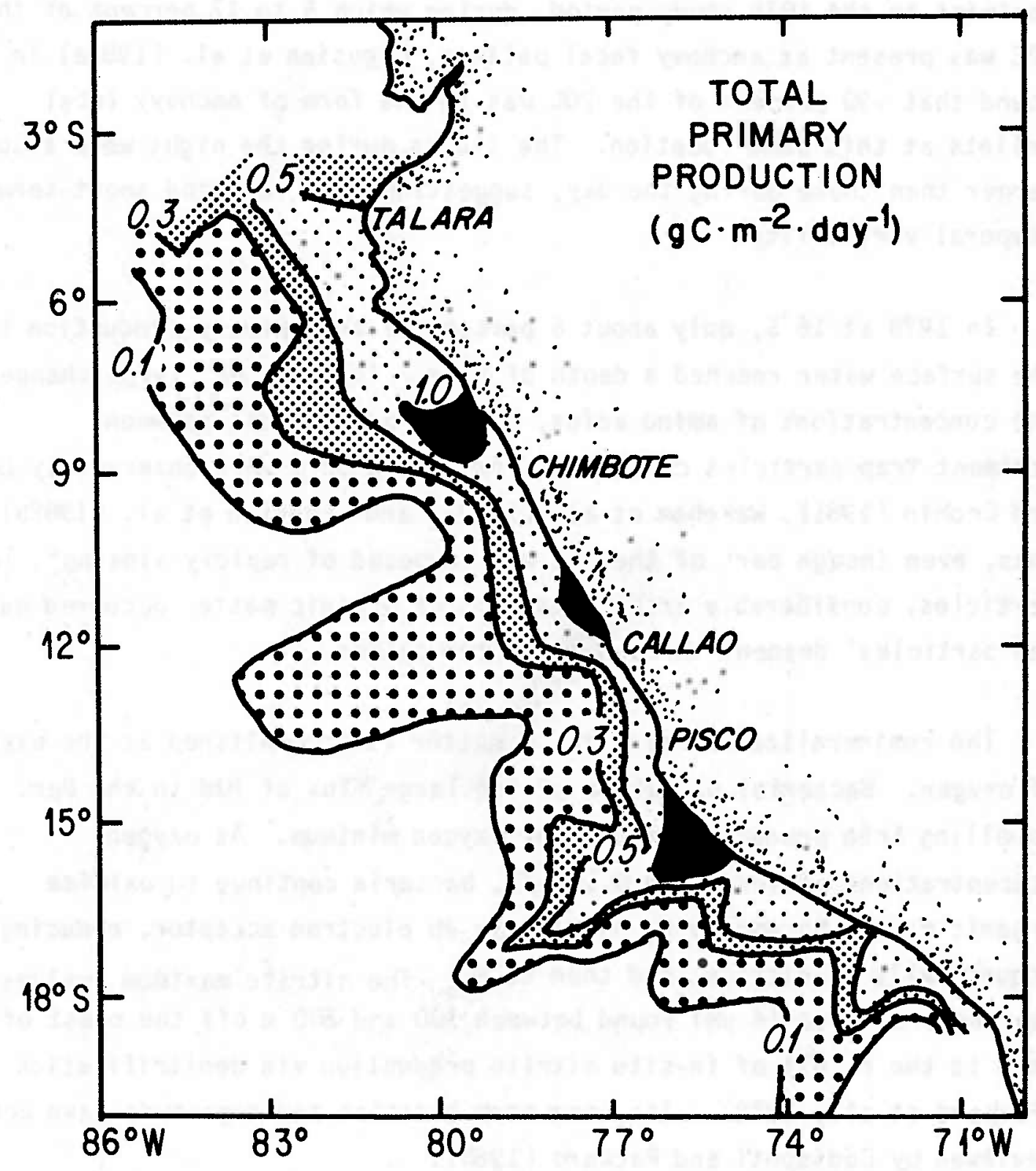


Staresinic (1978) observed mean POC fluxes of $275 \mathrm{mg} \mathrm{C} \mathrm{m}-212 \mathrm{hr}^{-1}$ through the euphotic zone. The particles were mostly diatoms, anchovy fecal pellets, euphausid molts, and unidentified fecal pellets. In contrast to the 1978 study period, during which 5 to 17 percent of the POC was present as anchovy fecal pellets, Gagosian et al. (1982a) in 1981 found that $>90$ percent of the POC was in the form of anchovy fecal pellets at this same location. The fluxes during the night were also larger than those during the day, suggesting both long and short-term temporal variability.

In 1978 at $15^{\circ} \mathrm{S}$, only about 6 percent of the primary production in the surface water reached a depth of $52 \mathrm{~m}$. In addition, large changes in the concentrations of amino acids, lipids, and sterols between sediment-trap particles collected from 14 and $52 \mathrm{~m}$ were observed by Lee and Cronin (1981), Wakeham et a1. (1982), and Gagosian et al. (1982b). Thus, even though part of the POM was composed of rapidly sinking*, large particles, considerable transformations of organic matter occurred during the particles' descent through the water column.

The remineralization of organic matter is accomplished at the expense of oxygen. Bacterial oxidation of the large flux of POM in the Peru Upwelling Area produces a mid-water oxygen minimum. At oxygen concentrations of less than $0.1 \mathrm{ml} / 1$, bacteria continue to oxidize organic matter by emp? oying nitrate as an electron acceptor, reducing it sequentially to nitri:e, and then to $N_{2}$. The nitrite maximum (values ranging from 1 to $14 \mu \mathrm{M}$ ) found between 100 and $500 \mathrm{~m}$ off the coast of Peru is the result of in-situ nitrite production via denitrification (Packard et al., 1978). Its long-term location and magnitude have been reviewed by Codispoti and Packard (1980).

*Staresinic (1982) has: observed sinking rates of $\sim 1000 \mathrm{~m} /$ day for large anchovy fecal pellets and $\sim 10$ to $100 \mathrm{~m} /$ day for zooplankton fecal pellets. 
Bacteria and protozoa, the organisms which mineralize organic matter, are present at very high concentrations in the waters of the Peru Upwelling region. Sorokin and Kogelschatz (1979) found that the main component of the plankton community at $15^{\circ} \mathrm{S}$ was micro-heterotrophic bacteria (equivalent to 5 to $120 \mu \mathrm{g}(/ 1$ ), which had a biomass 100 times greater than that of the phytoplankton. Similar bacterial abundances, $10^{6}$ to $10^{7} \mathrm{cell} \mathrm{s} / \mathrm{ml}$, were found at $15^{\circ} \mathrm{S}$ by Watson (1978). These large numbers, along with bacterial respiration rate measurements made in this area, suggest that bacterial biomass production and nutrient remineralization are dominant controls on the water-column nutrient concentrations, and thus of the primary and secondary productivity in this area (Sorokin and Kogelschatz, 1979).

Occasionally the flux of organic matter is so large, due to hydrographic conditions, that nitrate is completely removed from the water column. The mineralization of organic matter continues, employing sulfate as the electron acceptor. The occurrence of bacterial sulfate reduction in the waters off Peru has been reported by Dugdale and Goering (1977) in 1976 at $15^{\circ} \mathrm{S}$, Sorokin (1978) in 1975 at $9^{\circ} \mathrm{S}$, and by this author in 1981 at $12^{\circ} \mathrm{S}$.

The sediments off the coast of Peru are characterized by $h i g h$ organic-carbon contents ranging from 0.3 to $>20$ percent and are of extremely heterogeneous composition. Diatom and fish debris are abundant (Henrichs, 1980). Reported sedimentation rates vary from $1 \mathrm{~cm} / \mathrm{yr}$ at $15^{\circ} \mathrm{S}$ (Henrichs, 1980) to $0.05 \mathrm{~cm} / \mathrm{yr}$ at $13^{\circ} 40^{\prime} \mathrm{S}$ (Demaster, 1979). The benthic biomass is very large (100 times greater than that in the sediments of the Gulf of Mexicol and patchily distributed below the coastal waters of Peru, ranging from 8 to $2000 \mathrm{mg} \mathrm{C} / \mathrm{m}^{2}$ (Rowe, 1971). The distribution of biomass was found to depend in part upon the oxygen concentrations of the bottom waters. Low oxygen concentrations $(<0.1 \mathrm{ml} / 1)$ are associated with lower benthic biomass. On the other hand, large bacterial communities have been found in the sulfate-reducing sediments off the coast of Peru in areas where the bottom waters periodicaliy have low oxygen 
concentrations. Gallardo (1977) has determined that the majority of this biomass is composed of Thioploca, a filamentous bacterium. Not much is known about the metabolism of this organism, despite frequent observations of thick mats of Thioploca in sediments along the shelf break (Gallardo, 1977; Henrichs, 1980; Morita et al., 1981; Reimers, 1981 ; and this study). Waterbury (personal communication) and Reimers (1981) have suggested that in addition to being a sulfide oxidizer, this organism may facultatively fix nitrogen.

\section{Station Locations}

Four stations were occupied off the coast of Peru during March and April of 1981 during the annual event of upwelling. Station locations are shown in Figure 3-2. The first station, called Station SEAREX, was occupied on March 18, 1981 as part of the Sea-Air Exchange Program cruise, AII-108-3, centered at $15^{\circ} \mathrm{S}$. Stations A, B, and C, located along a transect away from the coast at $12^{\circ} \mathrm{S}$, were occupied during the first week of April on AII-1 88-4. These sites were chosen to provide samples subject to different mineralization processes (nitrification, denitrification, sulfate reduction), different lengths of water column (duration of the mineralization process), and differences in the size of the organic-matter flux.

\section{Station SEAREX:}

The southern-most station had an $80-\mathrm{m}$ water colurnn and was characterized by well-inixed conditions, as shown by the nutrient, temperature, salinity, and density profiles in Figures 3-3, 3-4, and 3-5. The low surface-vater temperature $\left(15.2^{\circ} \mathrm{C}\right)$, high phosphate $(2.5 \mu \mathrm{M})$, silicate $(25 \mu \mathrm{M})$, and nitrate $(10 \mu \mathrm{M})$ concentrations were indicative of intense upwelling, which was expected as this site has been previously shown to be a center of upwelling (Guillén, 1980). 0xygen concentrations were $10 \mathrm{v}$ throughout the water column (Figure 3-3). The high nitrite concentrations $(2 \mu \mathrm{M})$ found above $50 \mathrm{~m}$ suggest that denitrification had occurred (Figure 3-4). Between $50 \mathrm{~m}$ and $70 \mathrm{~m}$, 
Figure 3-2.

Station Locations in the Peru Upwelling Area (Bottom contours in meters) 
STATION LOCATIONS AII 108-4 APRIL 12-14, 1981

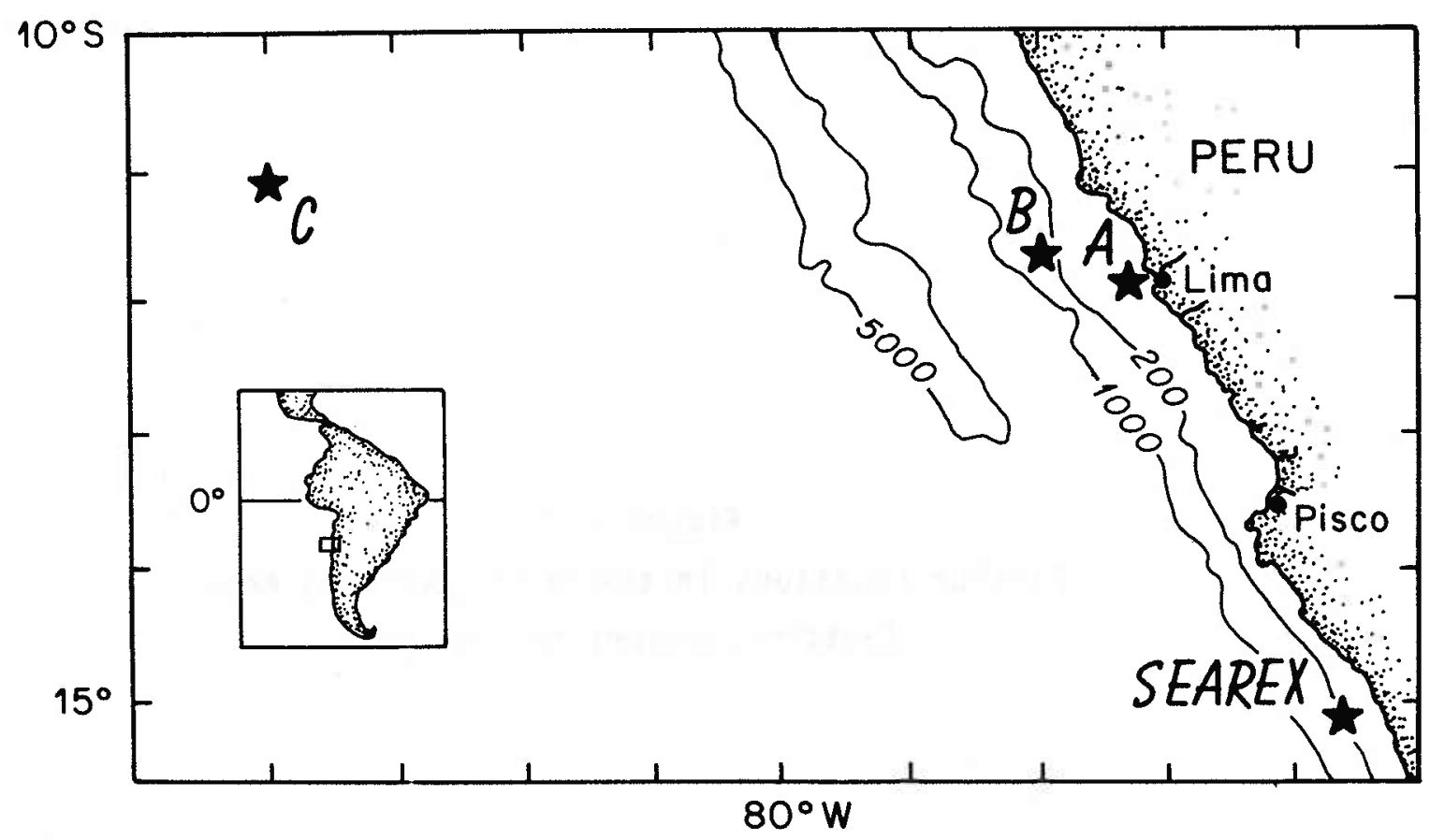


Figure 3-3.

Peru Upwelling Area

Station SEAREX: Phaeophytin, Chlorophyll a, Phosphate, Silicate and 0xygen Concentrations, from Gagosian et al. (1983) 


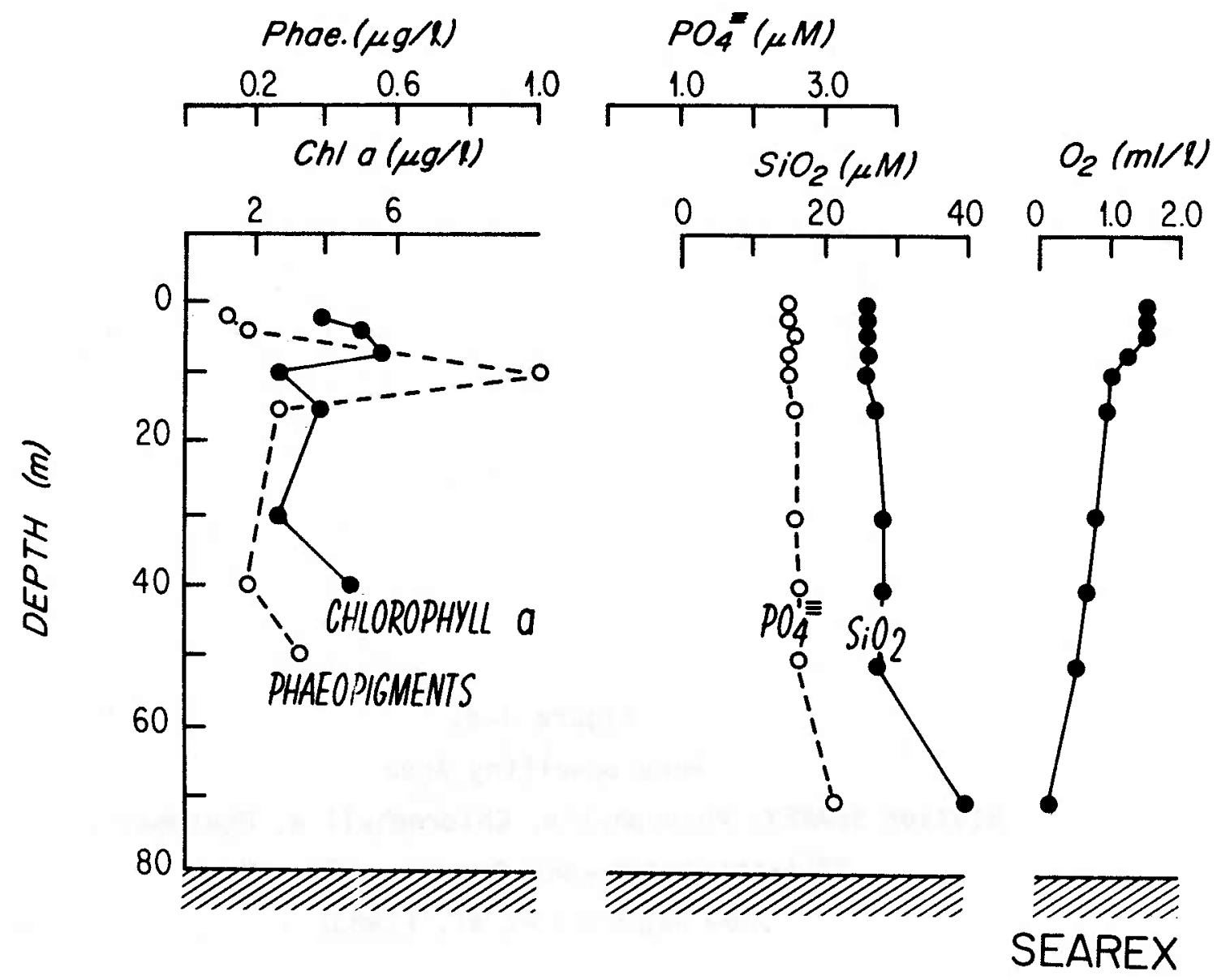


Figure 3-4.

Peru Upwelling Area

Station SEAREX: Nitrate, Ni trite, and Ammonia Concentrations, from Gagosian et al. (1983) 


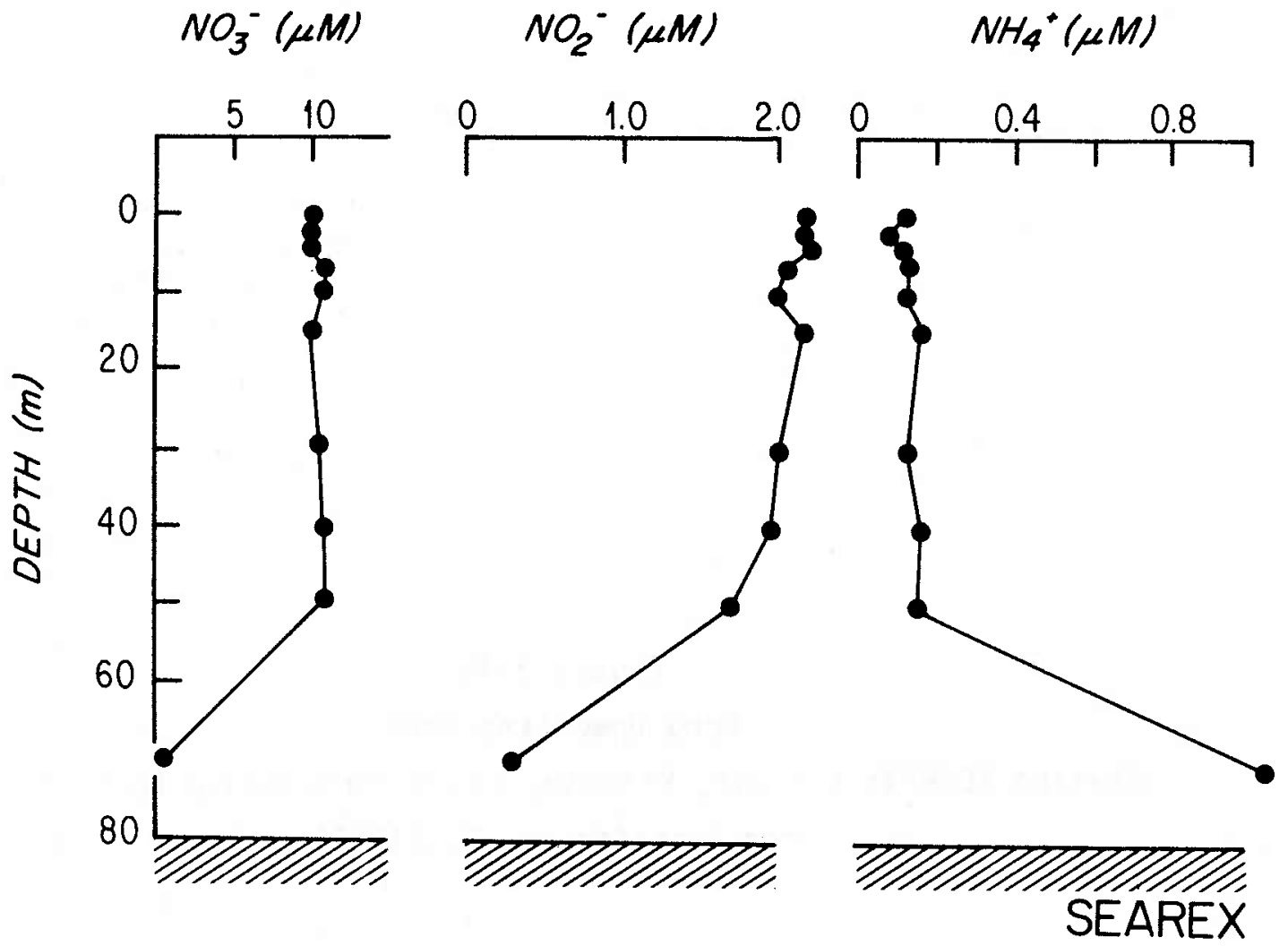


Figure 3-5.

Peru Upwelling Area

Station SEAREX: Temperature, Salinity, and Density, from Gagosian et al. (1983) 


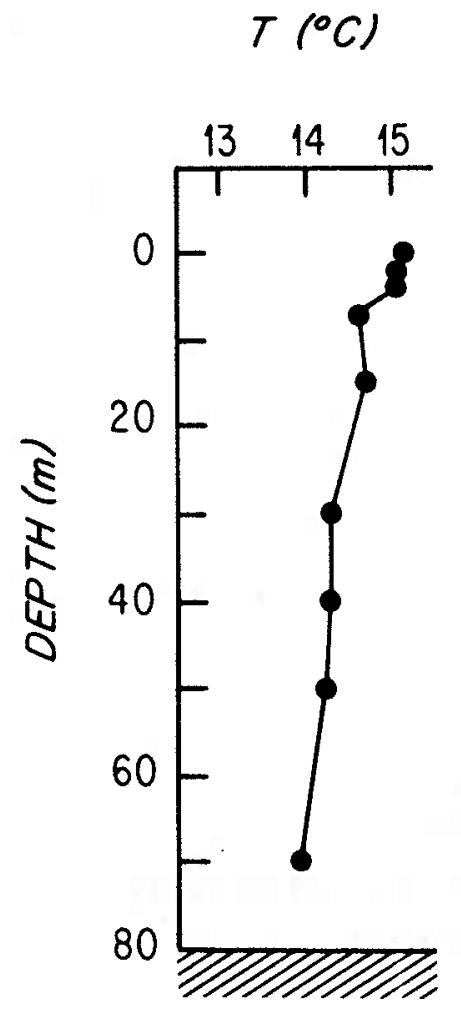

SALINITY (\%o)

$\Gamma^{34.8}, 35.0$

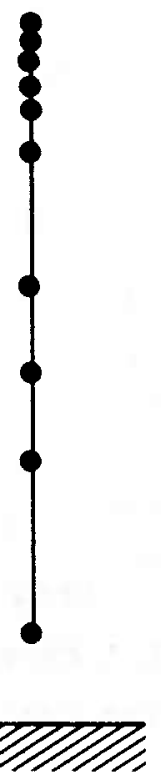

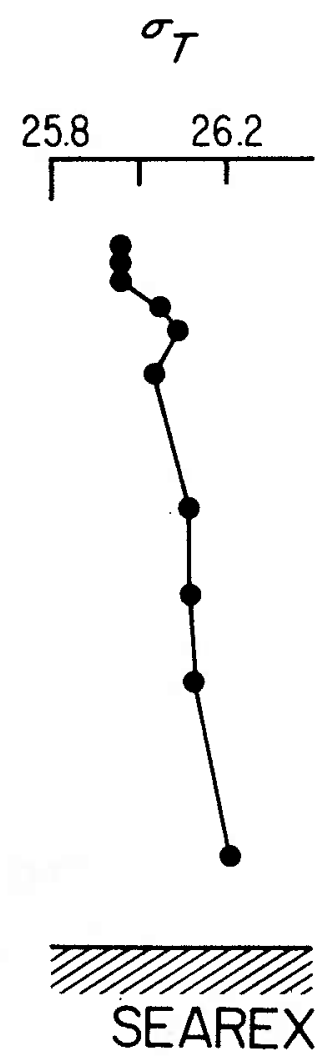


oxygen, nitrate, and nitrite concentrations decreased substantially, concomitant with large increases in ammonia, silicate, and phosphate concentrations. It appears that more efficient remineralization of organic matter took place below $50 \mathrm{~m}$, such that complete denitrification (conversion of nitrate and nitrite to $\mathrm{N}_{2}$ ) occurred. The absence of significant gradients in salinity and temperature (Figure 3-5) over this depth interval indicates that the transition below $50 \mathrm{~m}$ was biochemical in nature and not associated with the presence of a different water mass.

\section{Station A:}

Al though the coastal waters of Callao are often the site of another center of upwelling along the coast of Peru, the phenomenon is usually less intense than at $15^{\circ} \mathrm{S}$ (Maeda and Ki shimoto, 1970). Based on the nutrient and hydrographic data, this was al so the case in April of 1981. In comparison to Station SEAREX $\left(15.2^{\circ} \mathrm{C}\right)$, the surface-water temperature at Station $A$ was $18.6^{\circ} \mathrm{C}$ (Figure $\left.3-8\right)$. Surface-water phosphate (1.6 $\mu \mathrm{M}$ ) and silicate $(7.0 \mu \mathrm{M})$ concentrations (Figure 3-6) were lower than those found at Station SEAREX, but were within the mean winter surface concentrations determined by Guillén (1980) for this area.

Bel ow $10 \mathrm{~m}$, oxygen concentrations were very low, and from $20 \mathrm{~m}$ to the bottom $(48 \mathrm{~m})$ were at or below the $0.02 \mathrm{ml} / 1$ detection 1 imit (Figure 3-6). The very low concentrations of nitrate and nitrite throughout this short water column was evidence for complete denitrification (Figure 3-7). Below $20 \mathrm{~m}$, low oxygen concentrations $(<0.02 \mathrm{ml} / 1)$, high ammonia concentrations $(6.5$ to $10.5 \mu \mathrm{M})$, and the unmistakable odor of $\mathrm{H}_{2} \mathrm{~S}$, indicated that sulfate reduction had taken place in the lower part of the water column. Similar conditions were found by Dugdale and Goering (1977) in 1976 at $15^{\circ} \mathrm{S}$ and by Sorokin (1978) in 1975 at $9^{\circ} \mathrm{S}$. The maximum ammonia concentrations observed in 1977 at $15^{\circ} \mathrm{S}$ were approximately $7 \mu \mathrm{M}$, as compared to $10.5 \mu \mathrm{M}$ observed in 1981 at $12^{\circ} \mathrm{S}$. The TPM, POC, and PON concentrations (Figures 3-23 and 3-24), were extremely high at this station, even for coastal waters. The POC and TPM concentrations reached maxima of $300 \mu \mathrm{g} / 1$ and $3000 \mu \mathrm{g} / 1$ at $40 \mathrm{~m}$, 
$-101-$

Figure 3-6.

Peru Upwelling Area

Station A: Dissolved Organic Nitrogen, Total Dissolved Nitrogen, Phosphate, Silicate, and Oxygen Concentrations 


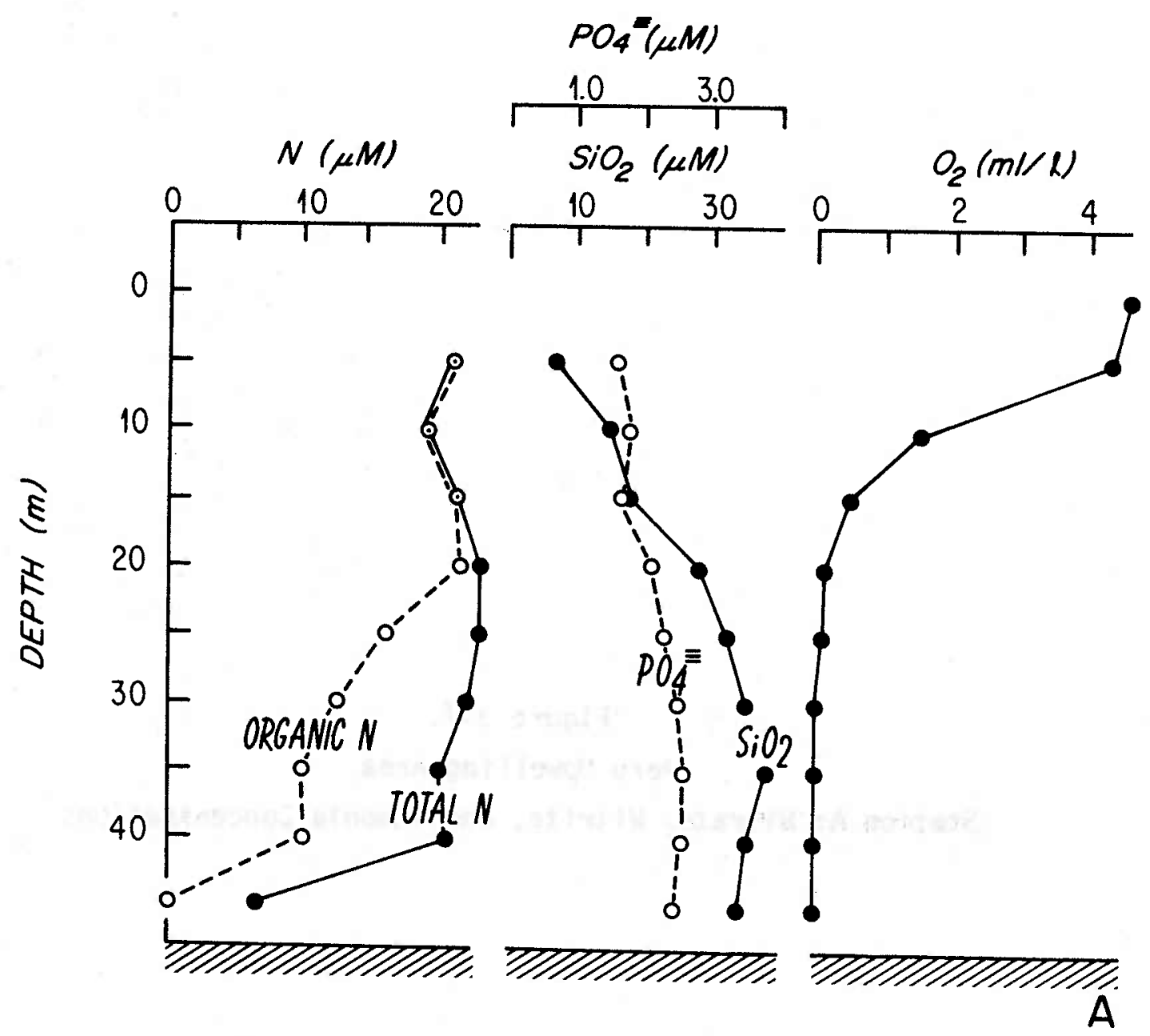


Figure 3-7.

Peru Upwelling Area

Station A: Nitrate, Nitrite, and Ammonia Concentrations 


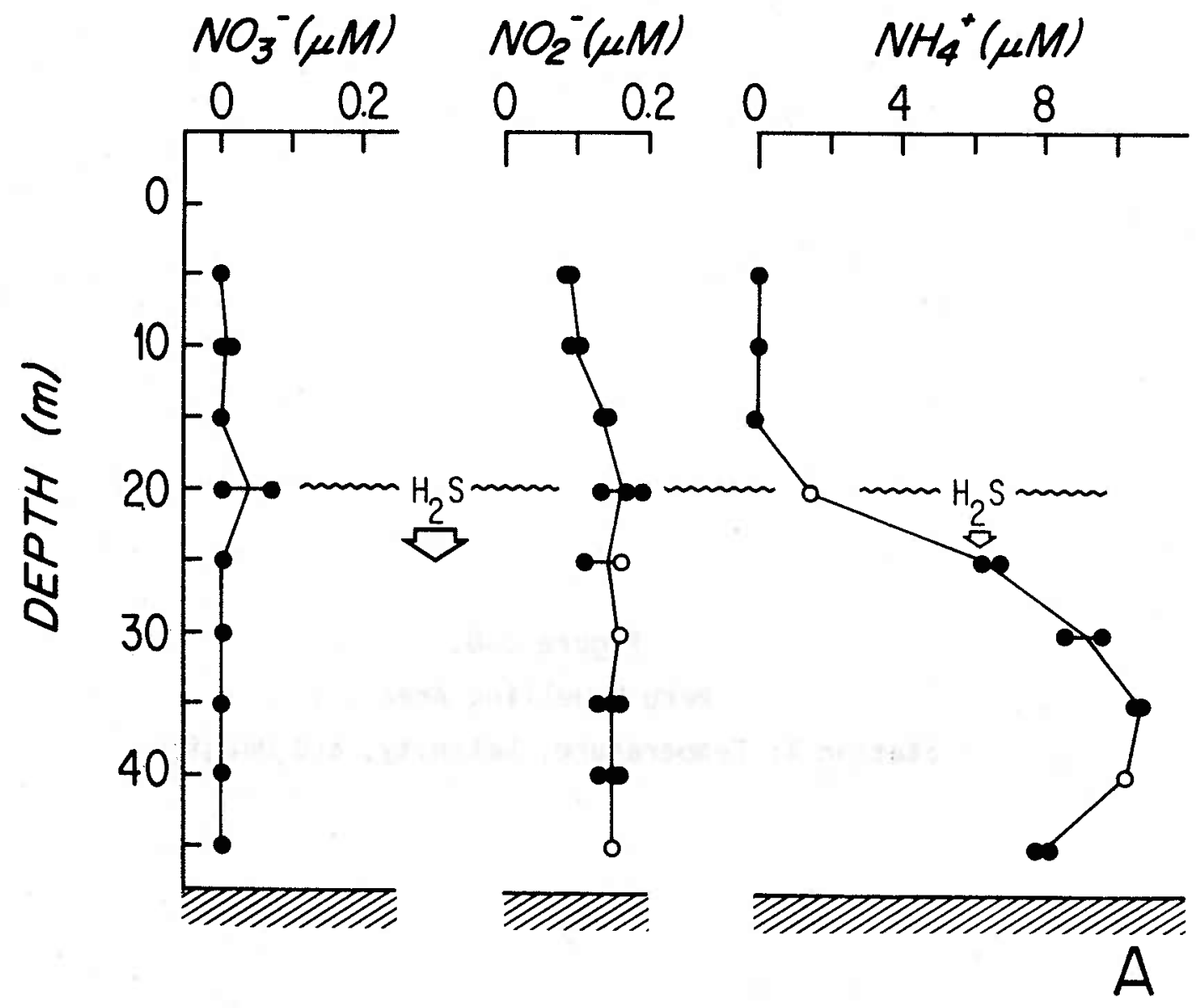


$-105-$

Figure 3-8.

Peru Upwelling Area

Station A: Temperature, Salinity, and Density 


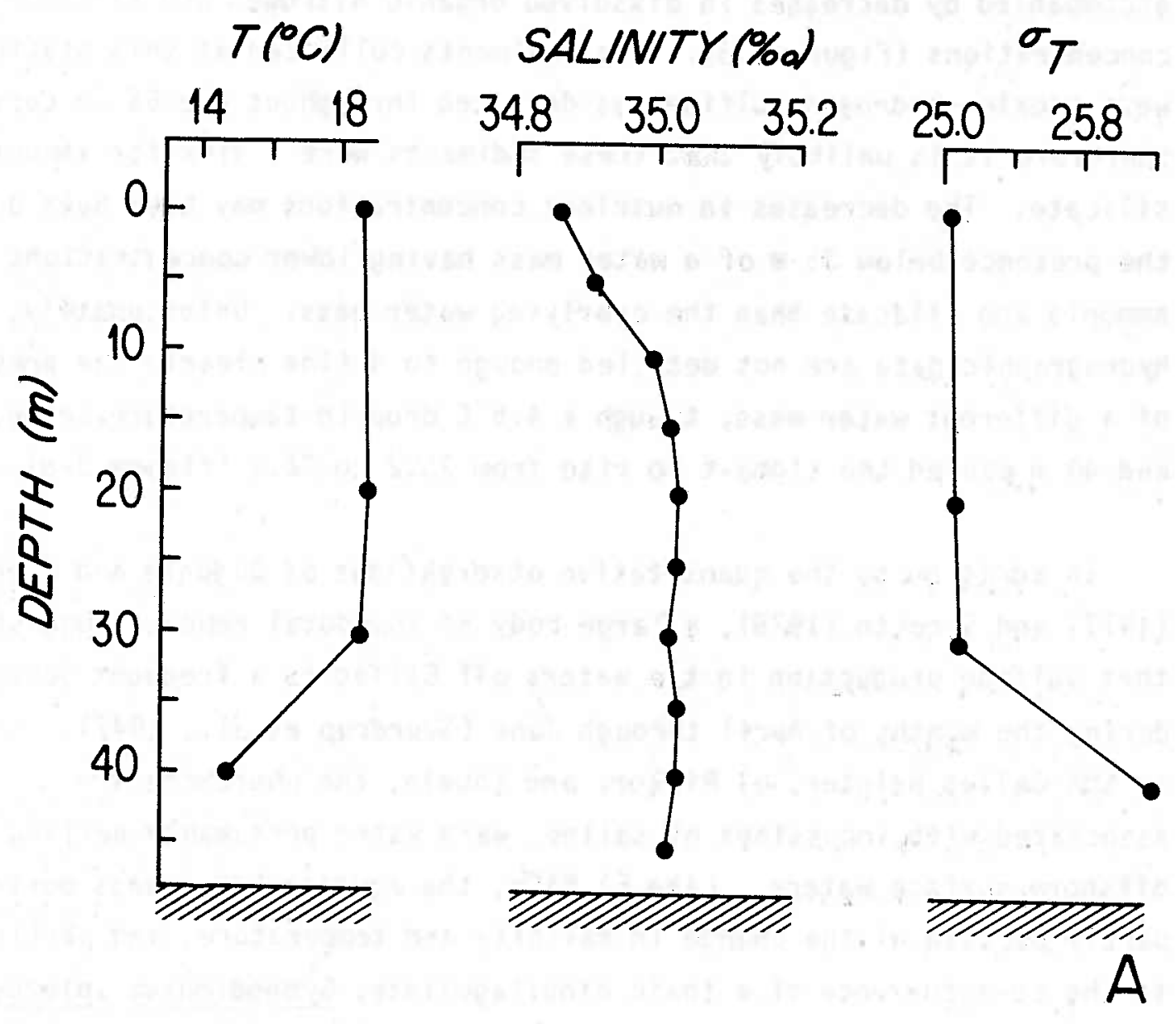


coinciding with the ammonia maximum, and may have been composed in part of sulfate-reducing microbial biomass.

The decrease in ammonia concentrations below $35 \mathrm{~m}$ (Figure 3-7) was accompanied by decreases in dissolved organic nitrogen and silicate concentrations (Figure 3-6). The sediments collected at this station were anoxic; hydrogen sulfide was detected throughout the $65-\mathrm{cm}$ core, therefore it is unlikely that these sediments were a sink for ammonia or silicate. The decreases in nutrient concentrations may have been due to the presence below $35 \mathrm{~m}$ of a water mass having lower concentrations of ammonia and silicate than the overlying water mass. Unfortunately, the hydrographic data are not detailed enough to define clearly the presence of a different water mass, though a $4.5^{\circ} \mathrm{C}$ drop in temperature between 30 and $40 \mathrm{~m}$ caused the sigma-t to rise from 25.2 to 26.1 (Figure 3-8).

In addition to the quantitative observations of Dugdale and Goering (1977) and Sorokin (1978), a large body of anecdotal reports suggests that sulfide production in the waters off $\mathrm{Callao}$ is a frequent occurrence during the months of April through June (Sverdrup et al., 1942). Known as the Callao painter, el Pintor, and aguaje, the phenomena are associated with incursions of saline, warm water presumably derived from offshore surface waters. Like El Nin̂́, the aguaje causes mass mortality, partly because of the change in salinity and temperature, and partly due to the co-occurrence of a toxic dinoflagellate, Gymnodimnium splendens, which often produces red tides under these conditions (Smith, 1978). Unlike El Niño, the aguaje is not accompanied by torrential rainfalls. The large amount of dead POM in the water column is remineralized at the expense of oxygen, then nitrate, and finally, if sufficient organic matter remains, sulfate reduction takes place. The abnormaliy high temperatures, POC, PON, and TPM concentrations, accompanied by 1 ow oxygen and DIN concentrations throughout the water column, suggest that a similar event took place at Station A in April of 1981. 
Station B:

Station B was located on the shelf break, in $330 \mathrm{~m}$ of water, $53 \mathrm{~km}$ from the coast. The nutrient and hydrographic profiles are similar to those found by other investigators in the Peru Upwelling Area (see Codispoti and Packard (1980) for a review), though surface water temperatures $\left(18.8^{\circ} \mathrm{C}\right)$ were higher, and phosphate $(0.8 \mu \mathrm{M})$, silicate $(2 \mu M)$, and nitrate $(3 \mu M)$ concentrations lower than the mean winter values $(1.8 \mu \mathrm{M}, 10 \mu \mathrm{M}$, and 5 to $10 \mu \mathrm{M}$, respectively) reported by Guillén (1980) for this site. Along with the modest size of the secondary nitrite maximum $(3.5 \mu M)$, this suggests that upwelling was not as intense as usual for this time of year and certainly not as intense as at Stations SEAREX and A. Further evidence for the vertical stability of the water column at Station $B$ is seen in the thermocline located between 20 and $50 \mathrm{~m}$ (Figure 3-11).

The nitrite profile at Station B (Figure 3-10) resembles those reported by Hafferty et a1. (1979) for this area in 1971: a primary nitrite maximum in the oxic region of the water column above a secondary nitrite maximum in the suboxic region. The primary maximum is caused by the oxidation of ammonia (nitrification), while the secondary maximum is generated by the reduction of nitrate (denitrification)( $\mathrm{Cline}$ and Richards, 1972). At Station B, the primary nitrite maximum $(0.5 \mu \mathrm{M})$ located at $20 \mathrm{~m}$ was coincident with a small ammonia maximum $(0.35 \mu \mathrm{M})$. As shown in Figure 3-27, a TPM concentration maximum $(1700 \mu \mathrm{g} / 1)$ coincided with the primary nitrite maximum, possibly being composed in part of nitrifying bacterial biomass. The second ammonia maximum $(0.2 \mu M)$ coincided with the secondary nitrite maximum $(3.5 \mu M)$ at $160 \mathrm{~m}$. Cline and Richards (1972) al so found ammonia maxima associated with denitrification in the Eastern Tropical North Pacific. They concluded that this ammonia was generated from the decomposition of organic matter and accumulated in the absence of oxygen, though most was lost to bacterial assimilation. 
$-109-$

Figure 3-9.

Peru Upwelling Area

Station B: Dissolved Organic Nitrogen, Total Dissolved Nitrogen, Phosphate, Silicate, and 0xygen Concentrations 


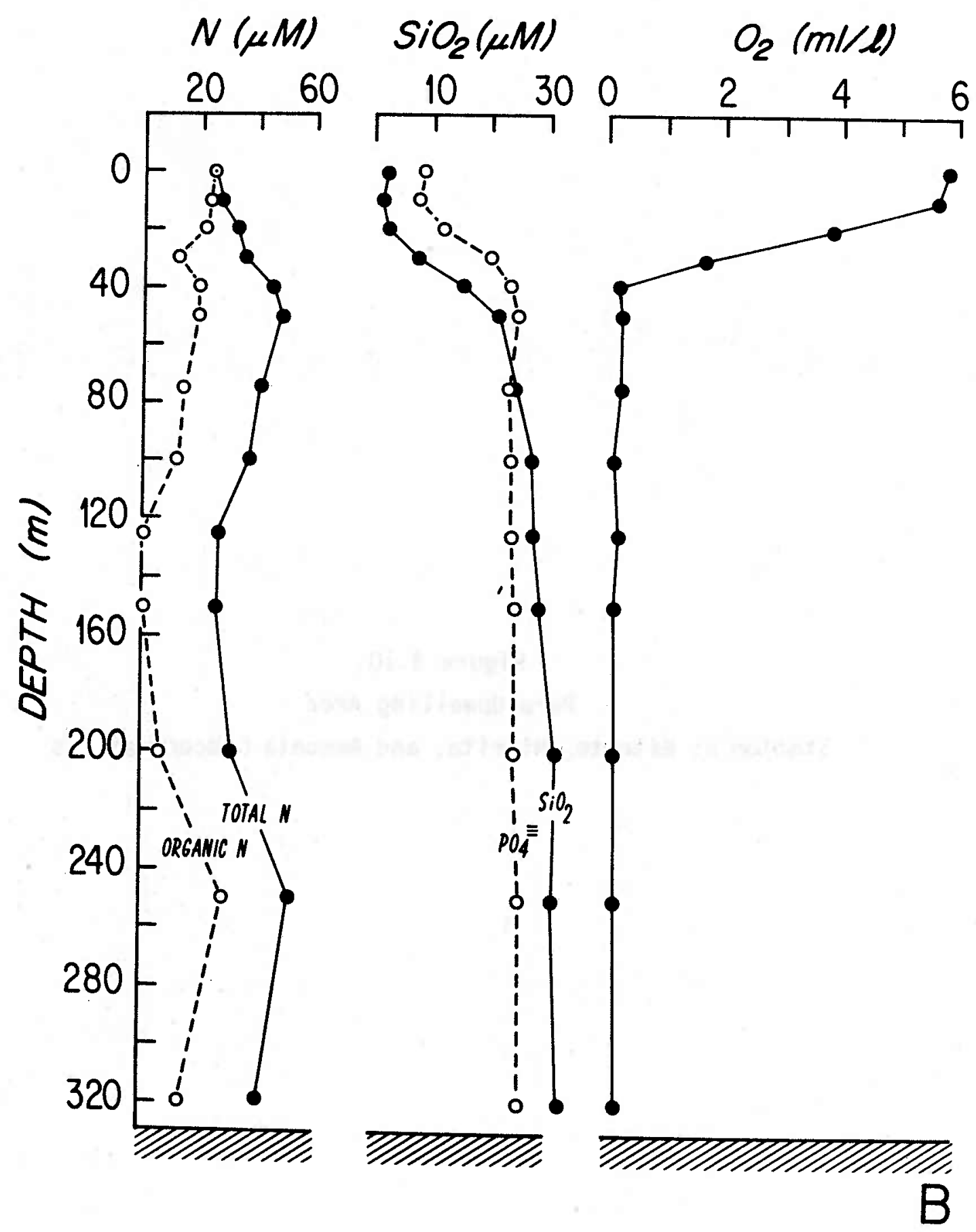


$-111-$

Figure 3-10.

Peru Upwelling Area

Station B: Nitrate, Nitrite, and Ammonia Concentrations 


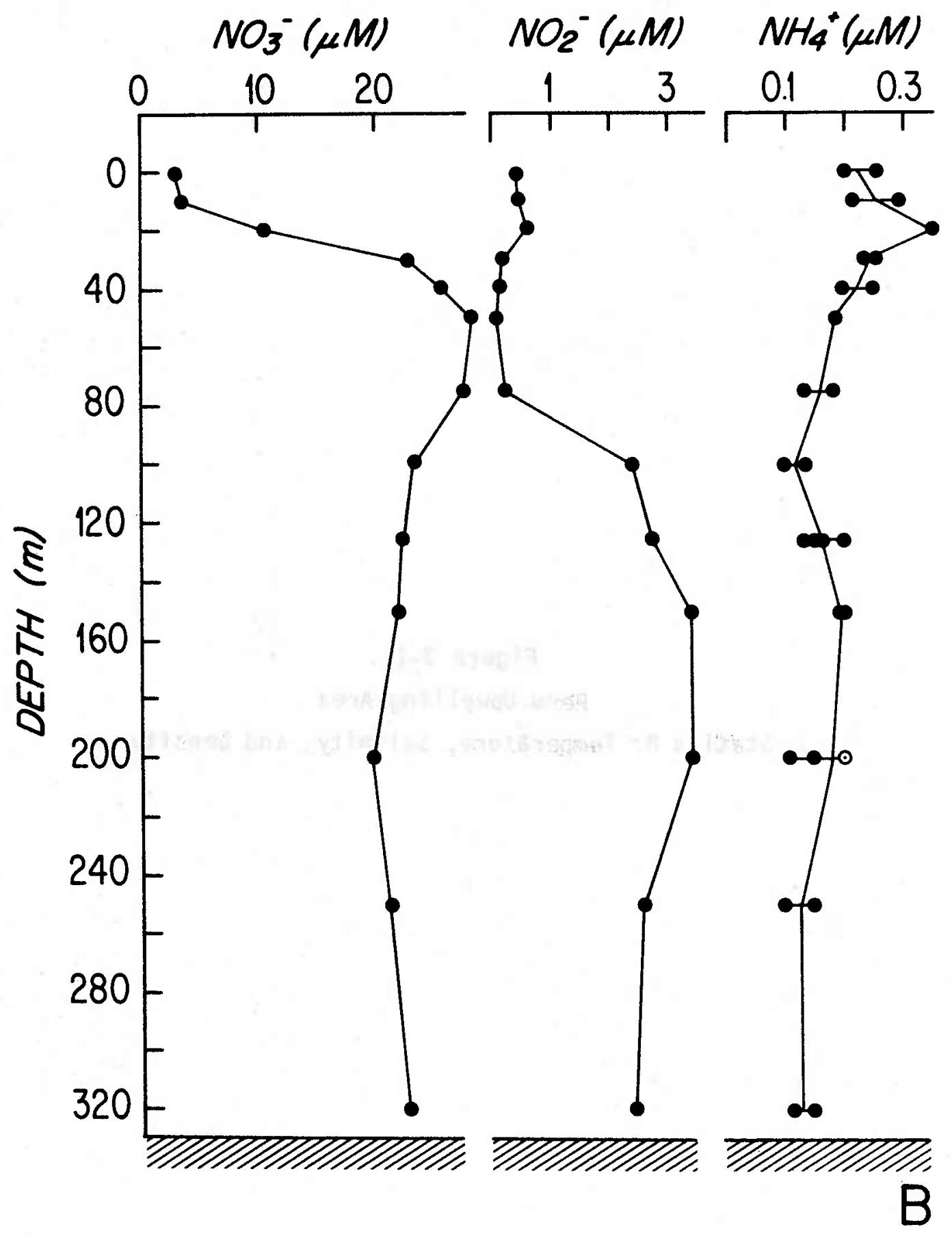


$-113-$

Figure 3-11.

Peru Upwelling Area

Station B: Temperature, Salinity, and Density 


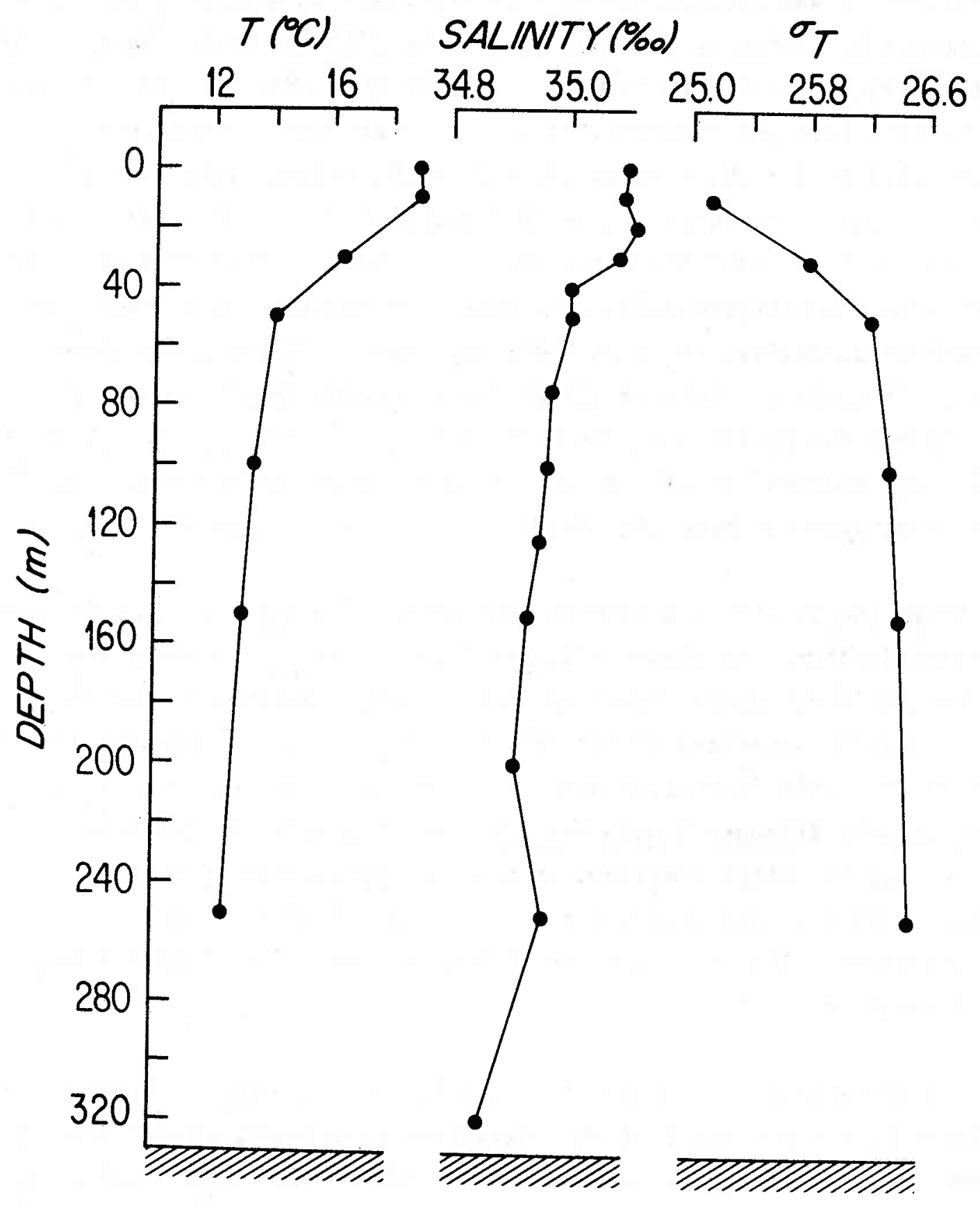

B 


\section{Station C:}

Station $C$ was located $609 \mathrm{~km}$ from the coast in $4580 \mathrm{~m}$ of water. As at Station $B$, surface-water temperature $\left(26.0^{\circ} \mathrm{C}\right)$ was higher than the mean winter temperature $\left(19\right.$ to $\left.20^{\circ} \mathrm{C}\right)$. Phosphate $(0.3 \mu \mathrm{M})$, silicate $(1 \mu \mathrm{M})$, and nitrate $(0.6 \mu \mathrm{M})$ concentrations were lower than the mean winter values ( 1.3 to $1.5 \mu \mathrm{M}, 5$ to $10 \mu \mathrm{M}$, and $<3 \mu \mathrm{M}$, respectively) for this site. Though a pronounced oxygen minimum $(0.1$ to $0.3 \mathrm{ml} / 1)$ was present from $100 \mathrm{~m}$ to at least $480 \mathrm{~m}$ (Figure $3-12$ ), the presence of a secondary nitrite maximum (Figure $3-13$ ) is doubtful, reflecting much lower rates of primary productivity, and thus POM flux, than found along the shelf break. In contrast, Patzert (1978) found a large (8 $4 \mathrm{M})$ secondary nitrite maximum centered at $100 \mathrm{~m}$ at this site in 1ate March of 1975. This large temporal as well as spatial variability of the secondary nitrite maximum has been discussed by Codispoti and Packard (1980).

Above the oxycline, a nitrite maximum at $60 \mathrm{~m}$ may have been produced by nitrification. As shown in Figure 3-13, an ammonia maximum was located at $40 \mathrm{~m}$. 01 son (1981) has observed that ammonia maxima and nitrite maxima generated by nitrification are not always present at the same depth. This is because nitrification occurs in two steps (See Introduction: Nitrogen Biogeochemistry) which proceed at different rates. But the nitrite maximum at $60 \mathrm{~m}$ is represented by a single data point, which may have been the result of analytical error and/or contamination. Thus, it is impossible to be certain that this nitrite maximum was real.

The upper water column was characterized by a permanent thermocline produced by the admixture of the low-salinity, low-temperature Antarctic Intermediate Water and the saline, warmer Subsurface Subtropical Water (Wyrtki, 1967). This thermocline was overlain by a near-surface seasonal thermocline which is usually produced by summer warming (Guillén, 1970) suggesting that the southern hemisphere winter of 1981 was warmer than usual. From 800 to $1000 \mathrm{~m}$, the salinity and temperature profiles are consistent with the presence of Equatorial Subsurface Water, the salinity 
$-116-$

Figure 3-12.

Peru Upwelling Area

Station C: Dissolved Organic Ni trogen, Total Dissolved Nitrogen, Phosphate, Silicate, and Oxygen Concentrations 


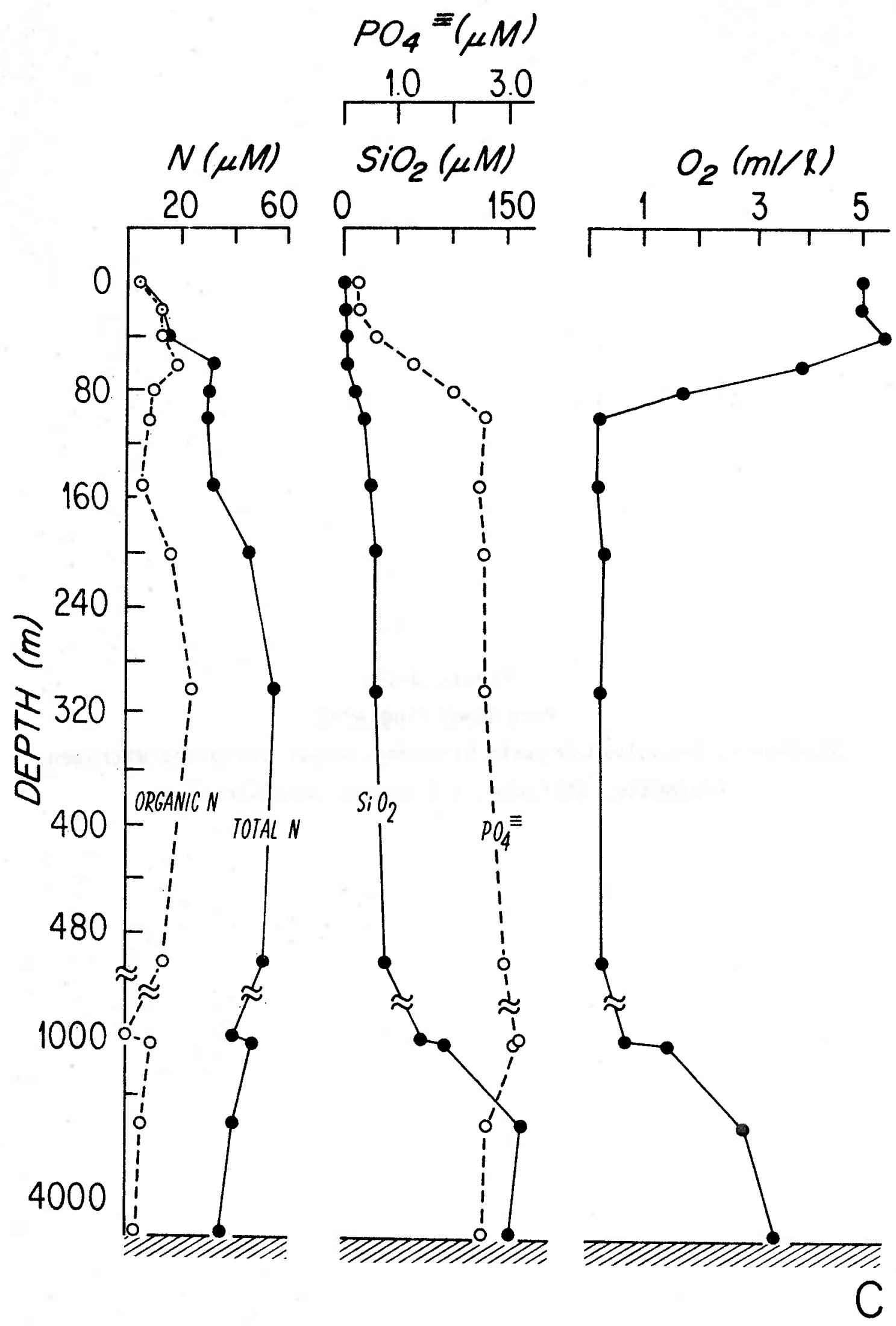


$-118-$

Figure 3-13.

Peru Upwelling Area

Station C: Nitrate, Nitrite, and Ammonia Concentrations 


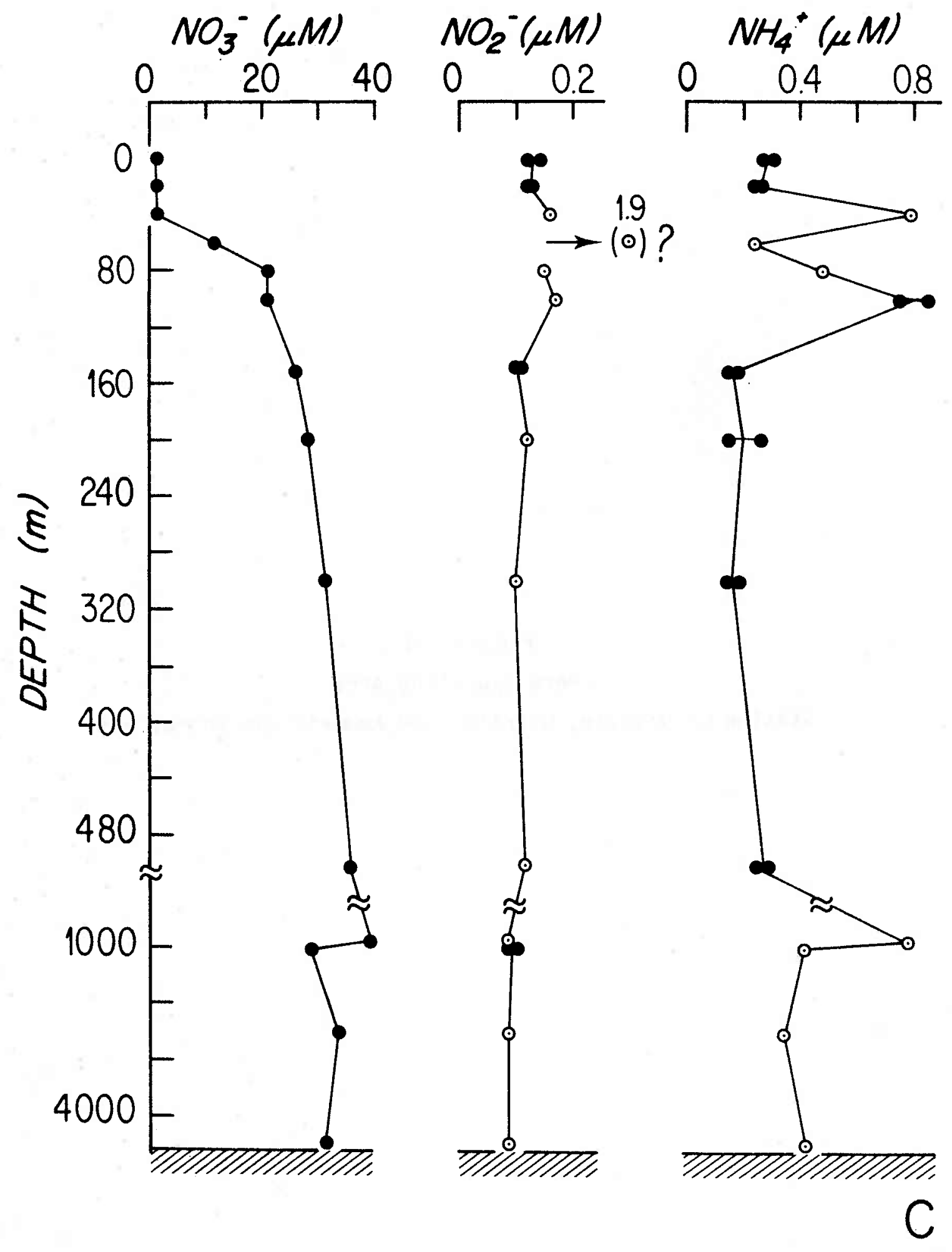


$-120-$

Figure 3-14.

Peru Upwelling Area

Station C: Temperature, Salinity, and Density 


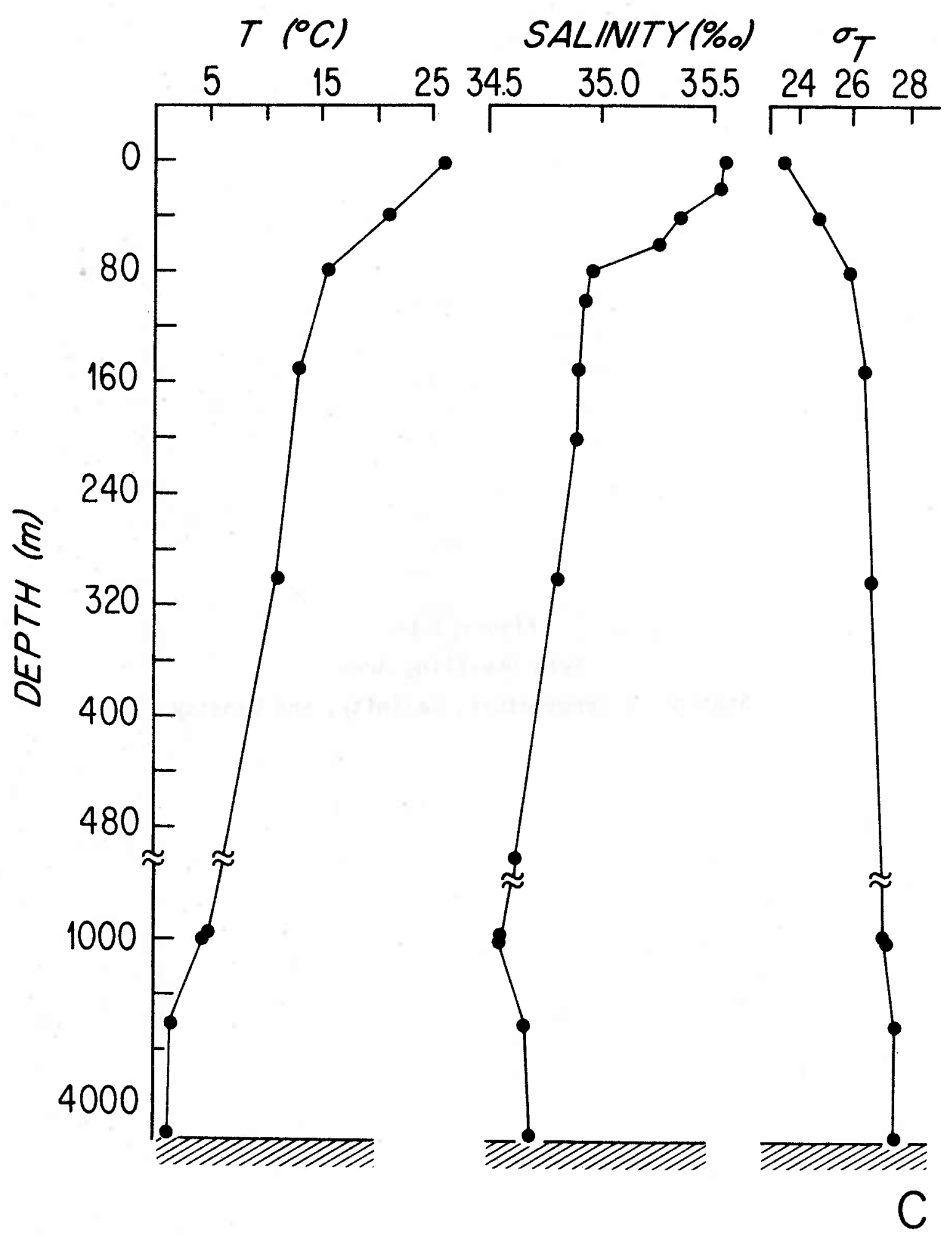


minimum at $1000 \mathrm{~m}$ being derived from Antarctic Intermediate Water. Below $1000 \mathrm{~m}$, changes in temperature, salinity (Figure 3-14), oxygen, silicate, and phosphate concentrations were consistent with the presence of Pacific Deep Water (Sverdrup et a 1., 1942).

In summary, the sea-surface temperature and phosphate, silicate, and nitrate concentrations at Stations SEAREX, $A, B$, and $C$, suggest that in 1981 upwelling was much less intense at 11 to $12^{\circ} \mathrm{S}$ than at $15^{\circ} \mathrm{S}$, and that the intensity of upwelling decreased with increasing distance from the coast. Upwelling usually brings cold nutrient-rich water to the sea surface and triggers high primary production. The $10 \mathrm{~W}$ POC, PON, and TPM concentrations found at Stations $B$ and $C$ were the result of diminished upwelling. At Station A, high POM concentrations appear to be the result of a localized phenomenon known as aguaje, rather than of upwelling.

\section{Plankton in the Peru Upwelling Area}

Species Composition and Isotope Analyses:

The results of the isotope and concentration measurements on the plankton tow catches from Stations SEAREX, A, B, and C are presented in Table 3-1. As described in the Sampling and Analytical Methods chapter, the net catch was sieved through Nitex mesh to separate the plankton into three size classes. Along with the nitrogen and carbon isotope ratios, percent organic carbon, $n i t r o g e n$ and $C / N$ ratios were determined. Because the samples were not rinsed with distilled water, a considerable amount of salt was present in the bulk and $<53 \mu \mathrm{m}$ fractions, biasing these percent organic carbon and nitrogen numbers towards low values. Replicate analyses were performed on three samples, Station A 53-333 $\mu \mathrm{m}$, Station $C>333 \mu \mathrm{m}$, and Station SEAREX $<53 \mu \mathrm{m}$, demonstrating a reproducibility of $\pm 0.2 \%$ for both the carbon and nitrogen isotope measurements.

Due to the high silicate concentrations in the surface waters, the diatom, Thallasiosira subtilis is abundant in the Peru Upwelling Area. 
Table 3-1.

Plankton from the Peru Upwelling Area:

Percent Organic Nitrogen and Carbon, $\mathrm{C} / \mathrm{N}$ Ratio, $\delta^{15} \mathrm{~N}$, and $\delta^{13} \mathrm{C}$

Station Size Fraction Percent $N$ Percent $C \quad C / N \quad \delta_{15}{ }_{\delta}^{13} \mathrm{C}$

$(0 / 00) \quad(0 / 00)$

\begin{tabular}{|c|c|c|c|c|c|c|}
\hline SE AREX & $\begin{array}{l}\text { Bulk } \\
>333 \mu \mathrm{m} \\
<53 \mu \mathrm{m} \\
" 1\end{array}$ & $\begin{array}{l}4.7 \\
9.3 \\
2.8 \\
2.8\end{array}$ & $\begin{array}{l}20.7 \\
38.1 \\
12.7 \\
12.6\end{array}$ & $\begin{array}{l}5.2 \\
4.8 \\
5.3 \\
5.3\end{array}$ & $\begin{array}{l}+11.4 \\
+12.9 \\
+9.2 \\
+9.4\end{array}$ & $\begin{array}{l}-16.7 \\
-16.8 \\
-16.0 \\
-.-\end{array}$ \\
\hline A & $\begin{array}{l}\text { Bulk } \\
>333 \mu \mathrm{m} \\
53 \text { to } 333 \mu \mathrm{m} \\
" 1 \\
<53 \mu \mathrm{m}\end{array}$ & $\begin{array}{l}1.9 \\
7.0 \\
1.6 \\
2.2 \\
2.0\end{array}$ & $\begin{array}{l}13.7 \\
25.5 \\
14.7 \\
15.7 \\
16.1\end{array}$ & $\begin{array}{r}8.3 \\
7.3 \\
10.7 \\
7.3 \\
9.6\end{array}$ & $\begin{array}{l}+12.7 \\
+12.9 \\
+12.8 \\
+12.6 \\
+7.8\end{array}$ & $\begin{array}{l}-19.8 \\
-20.7 \\
-20.2 \\
-20.0 \\
-19.5\end{array}$ \\
\hline B & $\begin{array}{l}\text { Bulk } \\
>333 \mu \mathrm{m} \\
53 \text { to } 333 \mu \mathrm{m} \\
<53 \mu \mathrm{m}\end{array}$ & $\begin{array}{l}4.2 \\
4.6 \\
3.7 \\
4.5\end{array}$ & $\begin{array}{l}21.8 \\
31.4 \\
21.2 \\
17.6\end{array}$ & $\begin{array}{l}6.1 \\
7.9 \\
6.7 \\
4.6\end{array}$ & $\begin{array}{l}+10.1 \\
+9.6 \\
+9.3 \\
+5.0\end{array}$ & $\begin{array}{l}-18.0 \\
-18.8 \\
-18.7 \\
-18.6\end{array}$ \\
\hline$c$ & $\begin{array}{l}\text { Bulk } \\
>333 \mu \mathrm{m} \\
\text { " } \\
53 \text { to } 333 \mu \mathrm{m} \\
<53 \mu \mathrm{m}\end{array}$ & $\begin{array}{l}5.3 \\
4.3 \\
3.6 \\
3.4 \\
2.6\end{array}$ & $\begin{array}{r}22.9 \\
30.2 \\
25.9 \\
21.6 \\
9.6\end{array}$ & $\begin{array}{l}5.1 \\
8.3 \\
8.3 \\
7.5 \\
4.3\end{array}$ & $\begin{array}{l}+4.9 \\
+9.2 \\
+9.1 \\
+9.2 \\
+6.7\end{array}$ & $\begin{array}{r}-19.8 \\
-20.1 \\
--- \\
-20.3 \\
-18.8\end{array}$ \\
\hline
\end{tabular}


The phytoplankton Rhizoselenia delicatula and Skeletonema costatum are al so abundant. Copepods and euphausiids are the dominant zooplankton (Santander, 1980). It is important to note that the anchovy biomass is very large, larger than that of the zooplankton (Whitledge and Packard, 1971). Large bacterial numbers have also been reported by Sorokin and Kogel schatz (1979) and Watson (1979).

All of the plankton fractions were microscopically examined to identify the major components in the samples. At Station SEAREX, Euphasusia mucrenata composed more than 90 percent of the biomass of the large size fraction $(>333 \mu \mathrm{m})$. Minor constituents were: eggs encased in gelatinous sheaths, centric diatoms, pteropods, and copepods. The small size fraction $(<53 \mu \mathrm{m})$ was composed of approximately 50 percent (by mass) of the diatom, Thallasiosira, and 50 percent amphipods. The unsieved plankton sample was composed mostly of Thallasiosira and Coscinodiscus, a centric diatom, with minor contributions of copepods and larval eggs.

The samples collected at Station SEAREX and at Station A represent the most $15 \mathrm{~N}$-enriched plankton yet reported in the 1 iterature. The relatively constant $\mathrm{C} / \mathrm{N}$ ratios of 4.8 to 5.3 were lower than the 7.0 average for phytoplankton suggested by Redfield et al. (1963). As shown in Figure 3-4, nitrate was present in the surface waters in micromolar amounts, suggesting that nitrogen was not limiting growth.

At Station $A$, undetectable amounts of DIN were found in the surface waters (Figure $3-7$ ). $C / N$ ratios were consequently larger than at Station SEAREX, indicating a more nitrogen-limited situation. The nitrogen isotope content of the samples was very similar to that found at Station SEAREX, though the $\delta^{13} \mathrm{C}$ values were much lower. The 1 arge size fraction was composed primarily of copepods, and the small fraction mostly of a pennate diatom, with Skeletonema, a chain diatom, and dinoflagellates, as minor constituents. The unsieved plankton sample was 10 percent copepods and 90 percent phytoplankton by mass. Five percent of the phytoplankton were the centrate diatom, Coscinodiscus, 5 percent a 
dinoflagellate, and 90 percent a pennate diatom. Although the low oxygen concentrations, absence of DIN, and presence of hydrogen sulfide at this station suggested red tide or aguaje conditions (Dugdale and Goering, 1977), the organism previously implicated in these phenomena, the dinoflagellate Gymnodimnium splendens (Smith, 1978), was not observed.

Station $B$ was located on the shelf break in the area characterized by a large secondary nitrite maximum centered $200 \mathrm{~m}$ bel ow the sea surface (Codispoti and Packard, 1980). The large size fraction collected at this site was composed of copepods and euphausiids and the small size fraction of phytoplankton (mostly Coscinodiscus), a few copepods, and some dinoflagellates. The bulk catch was notably reddish due to the large copepod component ( 90 percent by mass). Euphausiids contributed approximately 5 percent to the biomass and the remainder of the sample was seemingly amorphous red-brown matter and approximately 10- $\mathrm{mm}$ diameter spherical cells. The plankton from Station $B$ were also enriched in $15_{N}$ and $13 \mathrm{C}$, though not as markediy as at the inshore stations. The $C / N$ ratios reflect the greater availability of nitrogen in the surface waters compared to Station A (Figure 3-10).

The largest variety of organisms was collected at Station $C$. Separation of the net catch into size classes was complicated by the presence of a transparent gelatinous matrix. This mucus-like material may have been the remains of salps, ctenophores, or radiolaria. The remainder of the sample was composed of copepods (40 percent), larvaceans (20 percent), and of foraminifera and radiolaria (10 percent), with minor contributions of chaetognaths, snail larvae, and pteropods. The $<53-\mu \mathrm{m}$ fraction was composed mostly of unidentified yellow pellets, amphipods, copepods, and phytoplankton. The 1 ow $\delta^{15} \mathrm{~N}$ of the unsieved plankton sample was probably due to the presence of the gelatinous matrix which was mechanically removed during the size separations from the $>333-\mu \mathrm{m}$ and 53-to-333- $\mu \mathrm{m}$ size fractions and retained in the $<53-\mu \mathrm{m}$ size fraction.

The samples from Stations $B$ and $C$ were isotopically similar with 
respect to nitrogen, but the $\delta^{13} \mathrm{C}$ values of the Station $\mathrm{C}$ plankton were 1 to $2 \%$ lower than those measured for station $B$. Though the nitrate concentrations (Figure 3-13) in the surface waters at Station $C$ were lower $(1: 0 \mu \mathrm{M})$ than at Station $B$, the $C / N$ ratios of the plankton were similar.

Discussion of Plankton Results:

Ni trogen Isotopes:

The geographic distribution in $\delta^{15} \mathrm{~N}$ of marine plankton is shown in Figure 3-15. Samples composed of Trichodesmium were not included as this organism produces anomalously $15 \mathrm{~N}$-depleted organic matter by fixing $\mathrm{N}_{2}\left(0^{\circ} / 00\right)$ with little fractionation (Wada, 1980). Though Trichodesmium appears to fix a globally significant amount of nitrogen, it is numerically abundant only in tropical waters (Capone and Carpenter, 1982.). Unfortunately, the data base available for comparison of the nitrogen isotopic content of marine plankton collected in this study is limited to samples from the Northwestern Pacific (NWP) and the Eastern Tropical North Pacific (ETNP) 0cean. The 1 arger $\delta^{15} \mathrm{~N}$ of the plankton from the ETNP as compared to the NWP is probably due to the occurrence of denitrification in the ETNP.

The average $\delta^{15} \mathrm{~N}$ of the plankton samples from the NWP was $+5^{0} / 00$, from the ETNP, $+9 \%$, and from the Peru Upwelling Area, $+10^{\circ} / 00$. Similar $15 \mathrm{~N}$ enrichments in the biomass from the Peru Upwelling Area were found in the phytoplankton and zooplankton size classes (Figures 3-16 and 3-17). In contrast, the recent measurements by Reimers (1981) of plankton from the Peru Upwelling Area were considerably different $\left(+4.4^{\circ} / 00\right.$ and $\left.+7.4^{\circ} / 00\right)$ suggesting temporal variability in the $\delta^{15} \mathrm{~N}$ of plankton.

The ${ }^{15} \mathrm{~N}$ enrichments of the plankton from the Peru Upwelling Area can be attributed to two effects. First, the process of denitrification causes an $15_{\mathrm{N}}$ enrichment of the nitrate pool as the light isotope is 
Figure 3-15.

The Geographic Distribution of $\delta^{15} \mathrm{~N}$ in Marine Plankton

East Tropical North Pacific: Sweeney et a1. (1978)

Northwest Pacific: Wada and Hattori (1976)

Wada (1980)

Peru Upwelling Area: $\quad$ Reimers (1981)

This Study

Gulf of Maine: This Study

(The reported $\delta^{15} \mathrm{~N}$ values of the plankton have been rounded off to the nearest $1 \%$ oo.)

(The average $\delta^{15} \mathrm{~N}$ value of $\mathrm{p} 1$ ankton for a specific geographic area is indicated by an arrow to the left of the square 1 abeled AVERAGE.) 


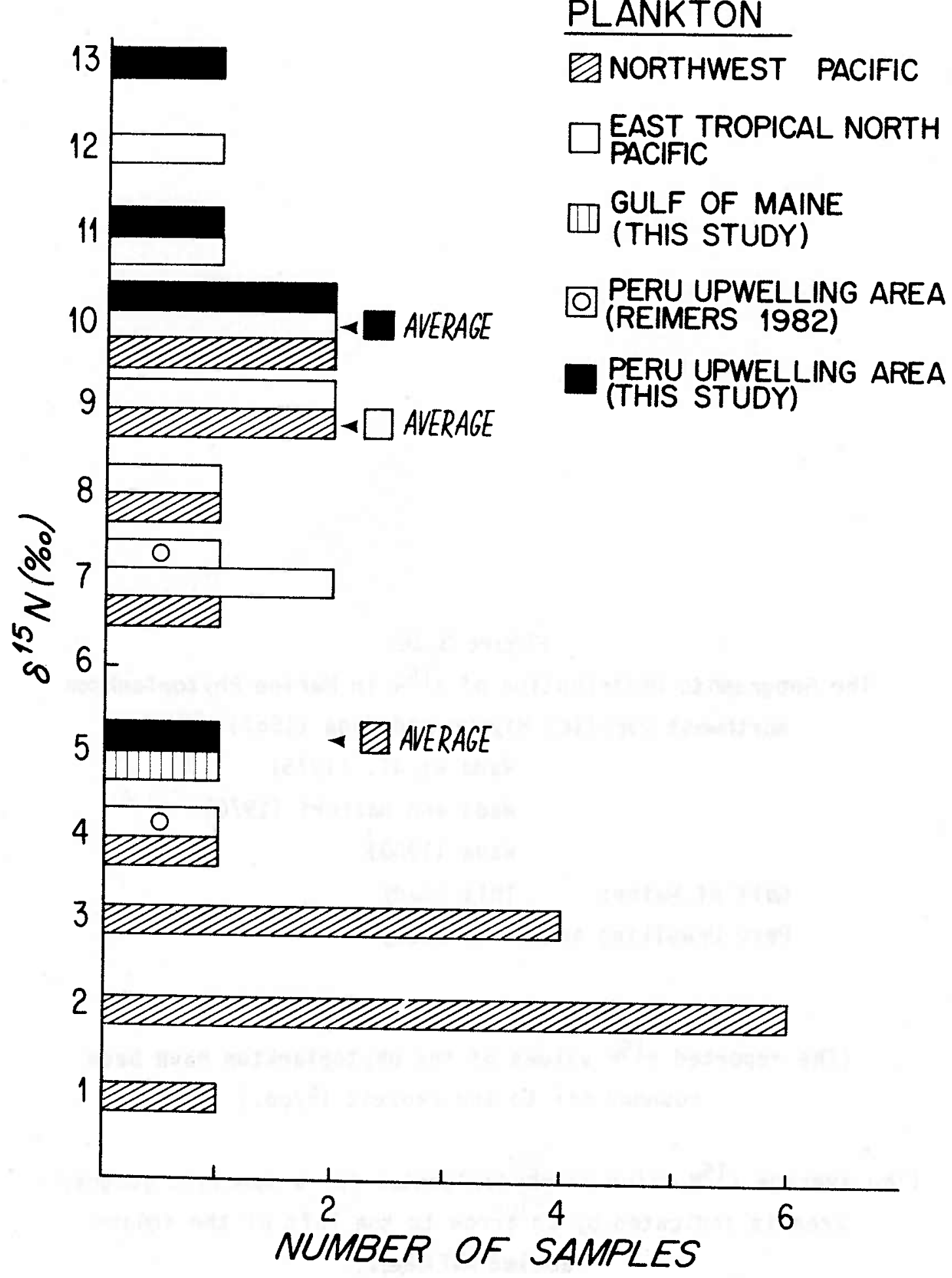


Figure 3-16.

The Geographic Distribution of $\delta^{15} \mathrm{~N}$ in Marine Phytoplankton Northwest Pacific: Miyake and Wada (1967) Wada et al. (1975) Wada and Hattori (1976) Wada (1980)

Gulf of Maine: This Study Peru Upwelling Area:This Study

(The reported $\delta^{15} \mathrm{~N}$ values of the phytoplankton have been rounded off to the nearest $1 \% \% 0$.)

(The average $\delta^{15} \mathrm{~N}$ value of phytoplankton for a specific geographic area is indicated by an arrow to the left of the square l abeled AVERAGE.) 


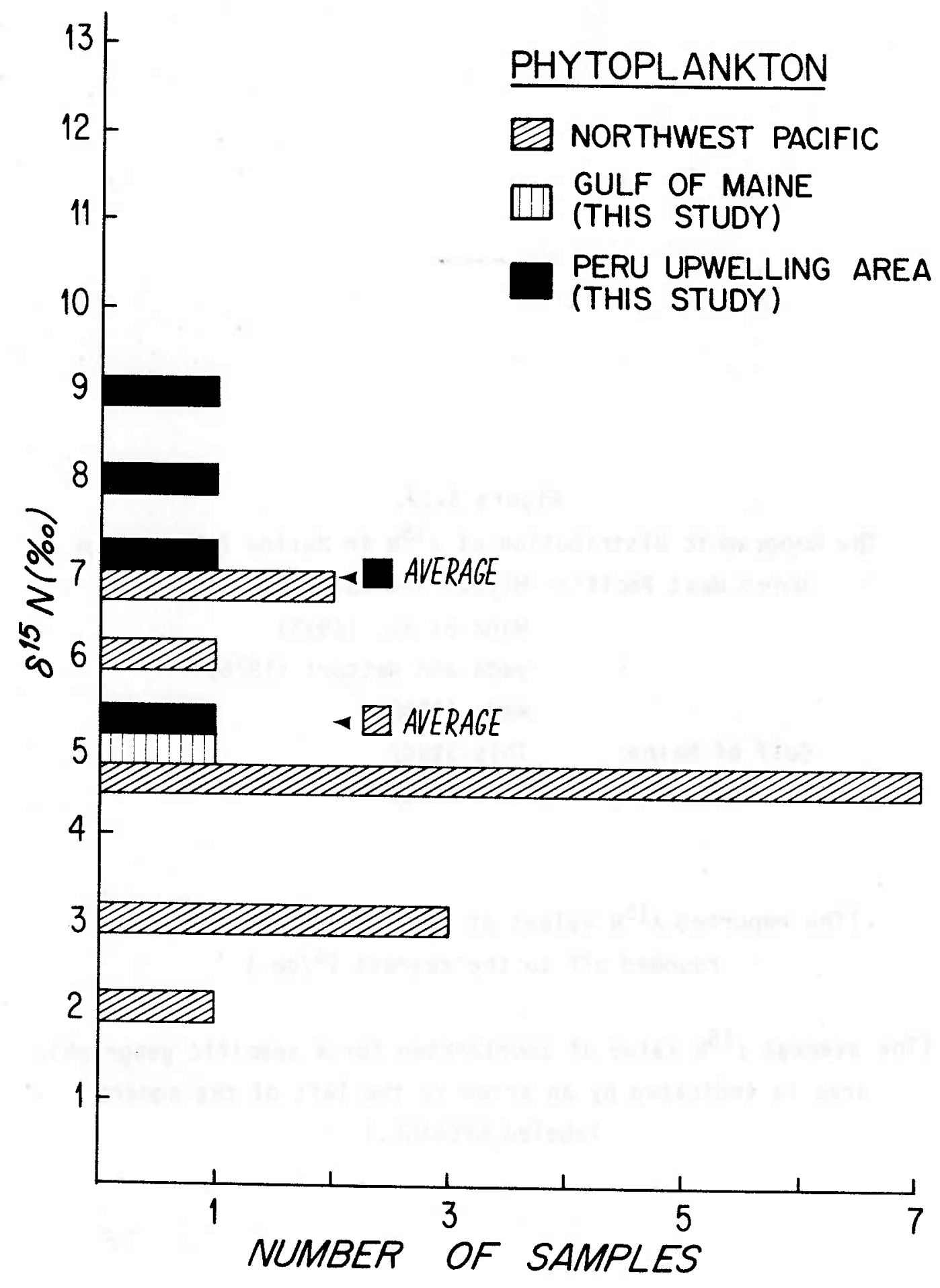


Figure $3-17$.

The Geographic Distribution of $\delta^{15} \mathrm{~N}$ in Marine Zooplankton North West Pacific: Miyake and Wada (1967)

Wada et al. (1975)

Wada and Hattori (1976)

Wada (1980)

Gulf of Maine: This Study

Peru Upwelling Area:This Study

(The reported $\delta^{15} \mathrm{~N}$ values of the zooplankton have been rounded off to the nearest $1 \%$ oo.)

(The average $\delta^{15} \mathrm{~N}$ value of zooplankton for a specific geographic area is indicated by an arrow to the left of the square 1 abeled AVERAGE.) 


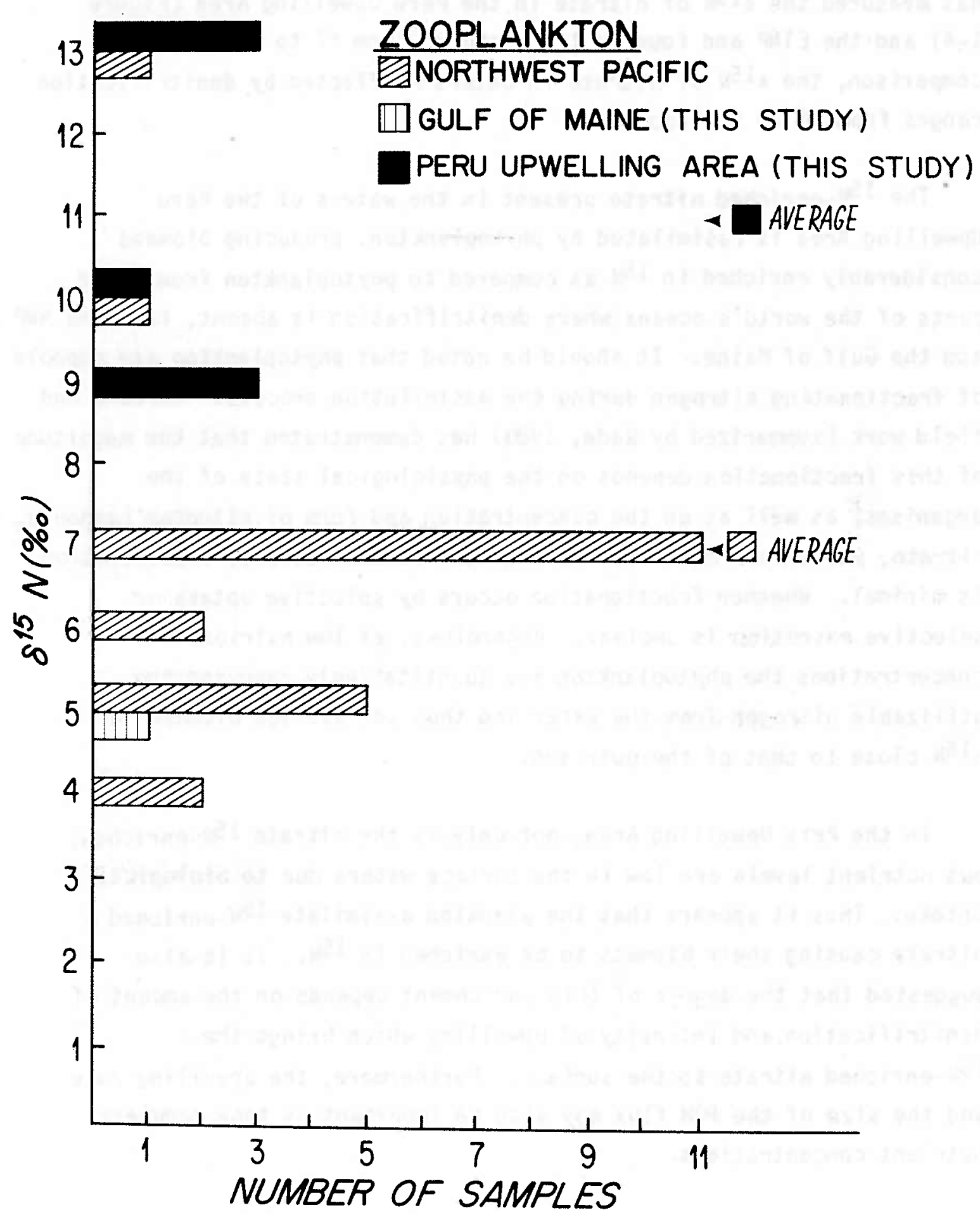


preferentially reduced to $\mathrm{N}_{2}$ (Cline, 1973 and Liu, 1979). Liu (1979) has measured the $\delta 15 \mathrm{~N}$ of nitrate in the Peru Upwelling Area (Figure 1-4) and the ETNP and found values ranging from +7 to $+16 \%$. In comparison, the $\delta 15 \mathrm{~N}$ of nitrate in waters unaffected by denitrification ranges from +5 to $+10 \%$.

The $15 \mathrm{~N}$-enriched nitrate present in the waters of the Peru Upwelling Area is assimilated by phytoplankton, producing biomass considerably enriched in $15_{\mathrm{N}}$ as compared to phytoplankton from other parts of the world's oceans where denitrification is absent, i.e. the NWP and the Gulf of Maine. It should be noted that phytoplankton are capable of fractionating nitrogen during the assimilation process. Culture and field work (summarized by Wada, 1980) has demonstrated that the magnitude of this fractionation depends on the physiological state of the organisms, as well as on the concentration and form of nitrogen (ammonia, nitrate, etc.) utilized. At low nitrogen concentrations, fractionation is minimal. Whether fractionation occurs by selective uptake or selective excretion is unclear. Regardless, at low nutrient concentrations the phytoplankton are quantitatively removing the utilizable nitrogen from the water and thus the average biomass has a ${ }_{\delta} 1 \mathrm{~N}_{\mathrm{N}}$ close to that of the nutrient.

In the Peru Upwelling Area, not only is the nitrate $15 \mathrm{~N}$-enriched, but nutrient levels are low in the surface waters due to biological uptake. Thus it appears that the plankton assimilate $15 \mathrm{~N}$-enriched nitrate causing their biomass to be enriched in $15 \mathrm{~N}$. It is also suggested that the degree of this enrichment depends on the amount of denitrification and intensity of upwelling which brings the $15 \mathrm{~N}$-enriched nitrate to the surface. Furthermore, the upwelling rate and the size of the POM flux may also be important as they regulate nutrient concentrations.

When nitrate concentrations are low, plankton assimilate ammonia and dissolved organic nitrogen (DON) (Keeney, 1973). The low surface DIN concentrations in the Peru Upwelling Area suggest that DON may have been 
an important source of nitrogen for the phytoplankton. If this was the case, the DON must have been enriched in 15N. As yet, no measurements of the $\delta 15 \mathrm{~N}$ of DON have been made. Since DON comprises a significant fraction of the fixed nitrogen in the water column, knowledge of its isotopic content is important.

The second possible cause of the $15 \mathrm{~N}$ enrichment has been observed by several investigators in other situations (Miyake and Wada, 1967; Wada and Hattori, 1976; and Pang and Nriagu, 1977; DeNiro and Epstein, 1981). The higher an organism is in the food chain, the more enriched it is in 15. This trophic-1evel enrichment can be seen in Figure 3-18. The smaller size fraction, composed primarily of phytoplankton, was 3 to $4 \%$ lighter than the 1 arge size fraction, which was composed primarily of zooplankton. Therefore, if a plankton tow is composed primarily of zooplankton, its $\delta 15 \mathrm{~N}$ tends towards higher values. But even when considered separately, the zooplankton and phytoplankton from the Peru Upwelling Area are both enriched in $15 \mathrm{~N}$ as compared to zooplankton and phytoplankton from other parts of the world's oceans where denitrification is absent (Figures 3-16 and 3-17).

The trophic enrichment is most likely caused by the preferential excretion of $15 \mathrm{~N}$-depleted ammonia or urea, or by production of $15 \mathrm{~N}$-depleted fecal pellets. It is difficult to postulate a mechanism for the selective uptake of the heavy isotope, since this requires that zooplankton fractionate, i.e. chemically transform, nitrogen while it is in particulate form. Alternatively, selective uptake may occur if $14 \mathrm{~N}$ is lost after assimilation but prior to biochemical use by the organism. As the light isotope would be lost in dissolved form, this process would closely resemble excretion.

The possibility of the production of $15 \mathrm{~N}$-depleted fecal pellets is supported by the results of isotopic analyses of sediment-trap particles collected at Station SEAREX of which more than 90 percent was anchovy fecal pellets. As shown in Figure 3-20, fecal pellets caught in the 
$-135-$

Figure 3-18.

$\delta^{15} \mathrm{~N}$ of $\mathrm{Pl}$ ankton Size Fractions

from the Peru Upwelling Area 
PLANKTON SIZE FRACTIONS

$<53 \mu \mathrm{m}$

- $53-333 \mu \mathrm{m}$

$\triangle>333 \mu \mathrm{m}$

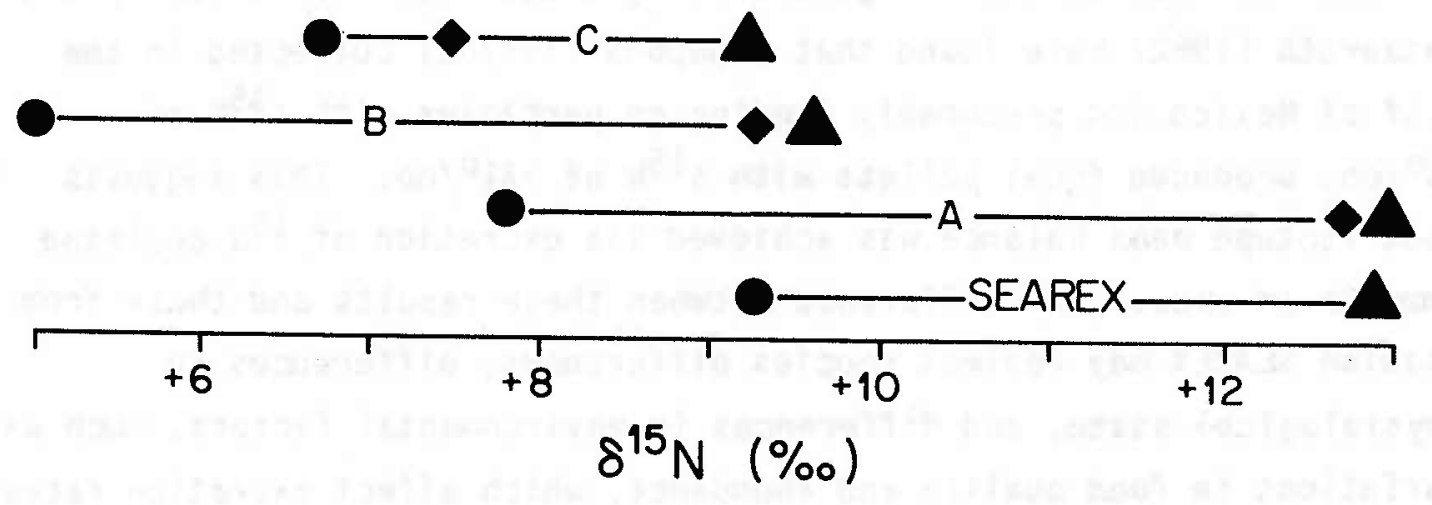


sediment trap 1 ocated $14 \mathrm{~m}$ bel ow the surface were $+9 \% / 00$, i.e. $4^{\circ} / 00$ lower than zooplankton $(12.9 \%$ ) from the same location. The food chain in the Peru Upwelling Area is short, anchoveta consume phy toplankton and zooplankton, which have al so grazed upon phytoplankton directly (Santander, 1980). No measurements on anchovy biomass were made, but since the $\delta^{15} \mathrm{~N}$ tends to increase with increasing trophic level, it is likely that the $\delta^{15} \mathrm{~N}$ of the anchovy fecal pellets was more than $4 \%$ oo lower than that of the source organism. This seems reasonable as the $\delta^{15} \mathrm{~N}$ values of fish have been found to range from +10 to $+20 \%$ (Miyake and Wada, 1967).

Caution must be used in generalizing these results. Checkley and Entzeroth (1982) have found that copepods $(+9 \% / 00)$ collected in the Gulf of Mexico and presumably feeding on particles with $\delta 1{ }^{15}$ of $+3^{0} / 00$, produced fecal pellets with $\delta^{15} \mathrm{~N}$ of $+11 \%$. This suggests that isotope mass balance was achieved via excretion of ${ }^{15} \mathrm{~N}$-depleted ammonia or urea. The difference between these results and those from Station SEAREX may reflect species differences, differences in physiological state, and differences in environmental factors, such as variations in food quality and abundance, which affect excretion rates (Quarmby, 1982).

Anchovy grazing plays an important part in controlling nutrient levels via excretion of soluble nitrogen and fecal pellet packaging of organic matter (Whitledge and Packard, 1971). Since both these processes may be important in controlling the $\delta^{15} \mathrm{~N}$ of nutrient nitrogen in the euphotic zone and that of the PON reaching the sediments, further attempts should be made to ascertain the cause of trophic isotope enrichment.

\section{Carbon Isotopes:}

The $\delta^{13} \mathrm{C}$ values of plankton $\left(-16.7\right.$ to $\left.-19.8^{\circ} / 00\right)$ (Table $\left.3-1\right)$ agreed closely with the measurements of Degens et al. (1968) on plankton collected in the Peru Upwelling Area. As seen by Degens, no correlation 
with surface-water temperature was observed, suggesting that differences in species composition of the net catches gave rise to the 1 arge range in ${ }^{1} 13 \mathrm{C}$. The importance of this species effect was demonstrated by the culture work of Wong and Sackett (1978). Large differences between ${ }^{13} \mathrm{C}\left(\delta^{13} \mathrm{C}\right.$ of substrate $\mathrm{CO}_{2}-\delta^{13} \mathrm{C}$ of biomass organic carbon) were found between various centric and pennate species of diatoms.

In contrast to the $\delta 15 \mathrm{~N}$ results, there appears to have been only a slight depletion in ${ }^{13} \mathrm{C}$ with increasing trophic level (Figure 3-19). There are conflicting reports in the literature concerning this phenomenon, with small (approximately $10 / 00$ ) ${ }^{13} \mathrm{C}$ enrichments with increasing trophic level being the most common observation (DeNiro and Epstein, 1978; Connaughey and McRoy, 1979). In contrast, Haines and Montague (1979) have observed no fractionation in a marsh ecosystem, and Macko (1982c) has observed ${ }^{13} \mathrm{C}$ depletions in amphipods with respect to the macrophytic algae they ingested. His results are comparable to the ${ }^{13} \mathrm{C}$ depletions of zooplankton relative to phytoplankton found by this author in the Peru Upwelling Area.

\section{Particulate Organic Matter}

Sampling and Analysis:

Except for the sediment-trap material collected at Station SEAREX, the POM measurements are the result of analyses of particles caught in 30-1 Niskin bottles. Due to analytical problems encountered when sea salts were present, approximately half of the POM analyses were done by the double-tube method described in the Appendix I. In the cases where the size of the blank created uncertainties greater than $0.2 \%$ in the isotope ratios, error bars corresponding to 1 standard deviation have been included. The results from the analyses of plankton and the surface sediment $(0-2 \mathrm{~cm})$ sample have been included in the profiles for purposes of comparison (Figures 3-20 through 3-33).

Along with the isotope data, POC and PON concentrations in units of 
$-139-$

Figure 3-19.

${ }^{13} \mathrm{C}$ of Plankton Size Fractions

from the Peru Upwelling Area 


\section{PLANKTON SIZE FRACTIONS}

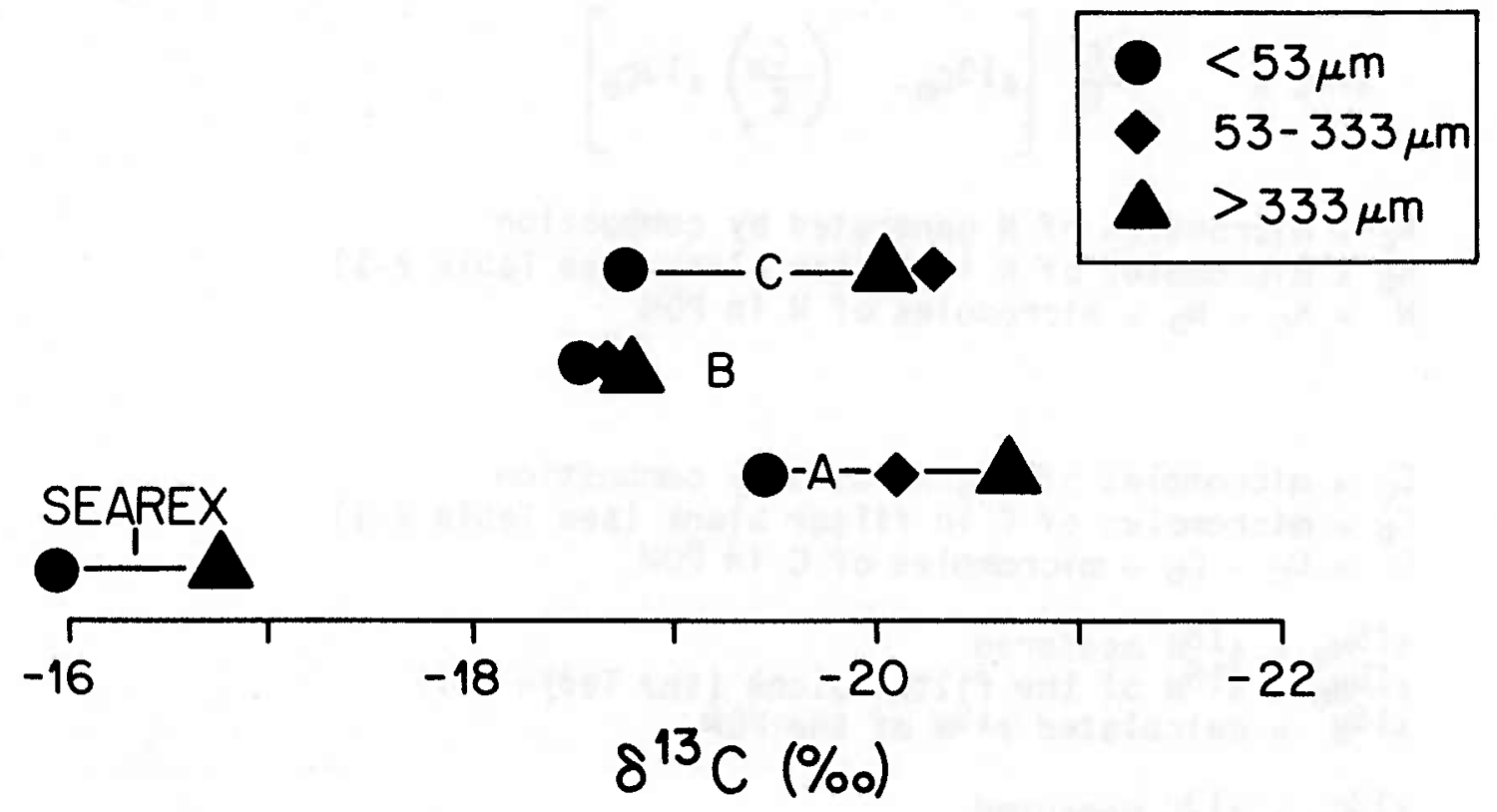


$\mu \mathrm{g} C / 1$ and $\mu \mathrm{g} \mathrm{N} / 1$ are presented. Where,

$$
\begin{aligned}
& {[P O N]=\frac{N \times 14}{V} ; \quad[P O C]=\frac{C \times 12}{V} ; C / N=\frac{C}{N}} \\
& \delta 15 N=\frac{N}{N C}\left[\delta^{15} N_{m}-\left(\frac{N_{b}}{N}\right) \delta^{15} N_{b}\right] \\
& \delta 13 C=\frac{C}{C}\left[\delta^{13} C_{m-}\left(\frac{C b}{C} \delta^{13} C_{b}\right]\right.
\end{aligned}
$$

$N_{c}=$ micromoles of $N$ generated by combustion

$N_{b}=$ micromoles of $N$ in filter blank (see Table 2-1)

$N=N_{c}-N_{b}=$ micromoles of $N$ in POM

$C_{c}=$ micromoles of $C$ generated by combustion

$c_{b}=$ micromoles of $C$ in filter blank (see Table 2-1)

$C=C_{C}-C_{b}=$ micromoles of $C$ in POM

$\delta 15 \mathrm{~N}_{\mathrm{m}}=\delta 15 \mathrm{~N}$ measured

$\delta 15 \mathrm{~N}_{\mathrm{b}}=\delta 15 \mathrm{~N}$ of the filter blank (see Table 2-1)

$\delta 15 \mathrm{~N}=$ calculated $\delta 15 \mathrm{~N}$ of the POM

${ }^{13} \mathrm{C}_{\mathrm{m}}=\delta^{13 \mathrm{C}}$ measured

$\delta 13 C_{b}=\delta 13 C$ of the filter blank (see Table 2-1)

$\delta 13 \mathrm{C}=\mathrm{calculated} \delta 13 \mathrm{C}$ of the POM

$V=$ liters of seawater filtered

The TPM concentrations were determined by weighing Nuclepore filters before and after filtration of 1 to 51 of sea water. These filters were rinsed with distilled water to remove sea salt. The filters used for isotope measurements were not rinsed as this step was shown to cause loss of carbon and nitrogen and alteration of isotope ratios (Appendix II). The percentages of organic carbon and nitrogen in the particles (Figures $3-25,3-29$, and $3-33$ ) are defined as:

$$
\text { "percent PON" }=\left[\frac{[\mathrm{PON}]}{[\mathrm{TPM}]}\right] \times 100 ; \text { "percent POC" }=\left[\frac{[\mathrm{POC}]}{[\mathrm{TPM}]}\right] \times 100
$$


In the surface waters, where the organic fraction was very 1 arge, the sum of the "percent PON and POC" of ten reached more than 80 percent. This suggests that distilled-water washing during the TPM concentration determinations caused loss of a significant fraction of the TPM in the form of organic matter, which was solubilized as cells were lysed. Except for the surface values, the "percent PON and POC" results are similar to the few carbon and nitrogen values in the literature (Chester and Stoner, 1974; Rowe and Gardner, 1979; Honjo, 1980). The decrease with increasing depth in the water column and the decrease between the deepest values and the percent organic carbon and nitrogen in the surface sediments suggest that the calculated parameter is a valid measurement where organic matter is a small fraction of the total particle load. It is also possible that the water filtered for the PON and POC concentration measurements had a different particle composition from that used for TPM concentration determinations, though both aliquots came from the same Niskin bottle. The problems associated with particle sampling with Niskin bottles have been discussed by Gardner (1976).

Results of Isotopic Analyses of POM:

\section{Station SEAREX:}

The results of the sediment-trap material collected at Station SEAREX have been interpreted thus far in relation to the accompanying plankton. The $\delta^{15} \mathrm{~N}$ of the two trap samples was 3 to $6 \%$ oo lighter than that of the plankton, the lower trap particles closely resembling the surface sediment in this area (Figure $3-20$ ).

In comparing the sediments to the pellets, it should be noted that, though large particles have been shown to comprise a significant portion of the mass flux to the sediments, their relative abundance in the water column at this station varies in time. In the 1978 study period, Staresinic (1978) found that 5 to 17 percent of the POC flux was composed of fecal pellets, whereas in 1981, Gagosian et al. (1982a) found that approximately 90 percent of the POC flux was in the form of fecal 
Figure 3-20.

Peru Upwelling Area

Station SEAREX: $\delta^{15} \mathrm{~N}$ and $\delta^{13} \mathrm{C}$ of Plankton, POM Collected in Sediment Traps, and Surface Sediments $(0-2 \mathrm{~cm})$ 


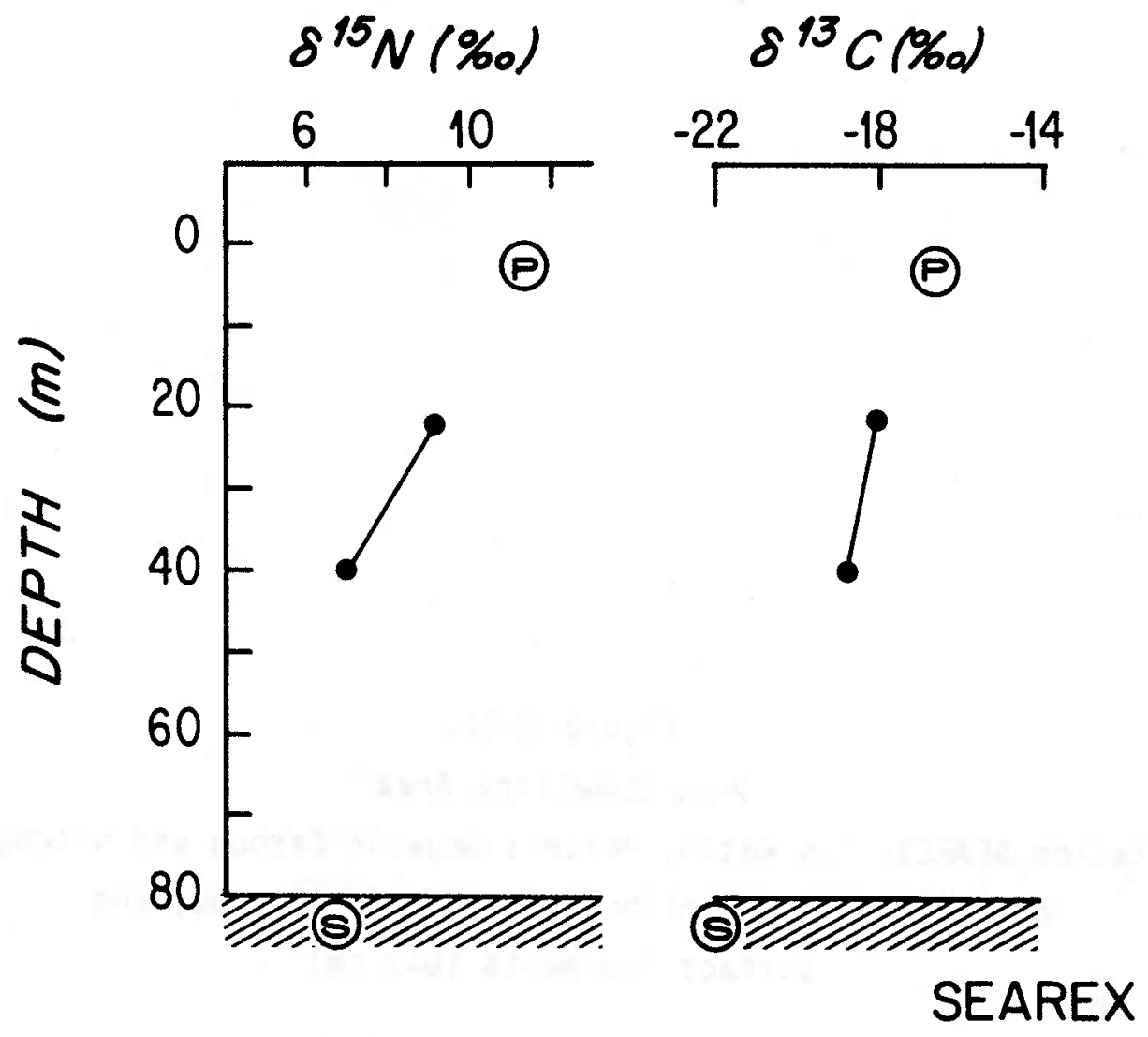


Figure 3-21.

Peru Upwell ing Area

Station SEAREX: C/N Ratio, Percent Organic Carbon and Nitrogen of Plankton, POM Collected in Sediment Traps, and Surface Sediments $(0-2 \mathrm{~cm})$ 


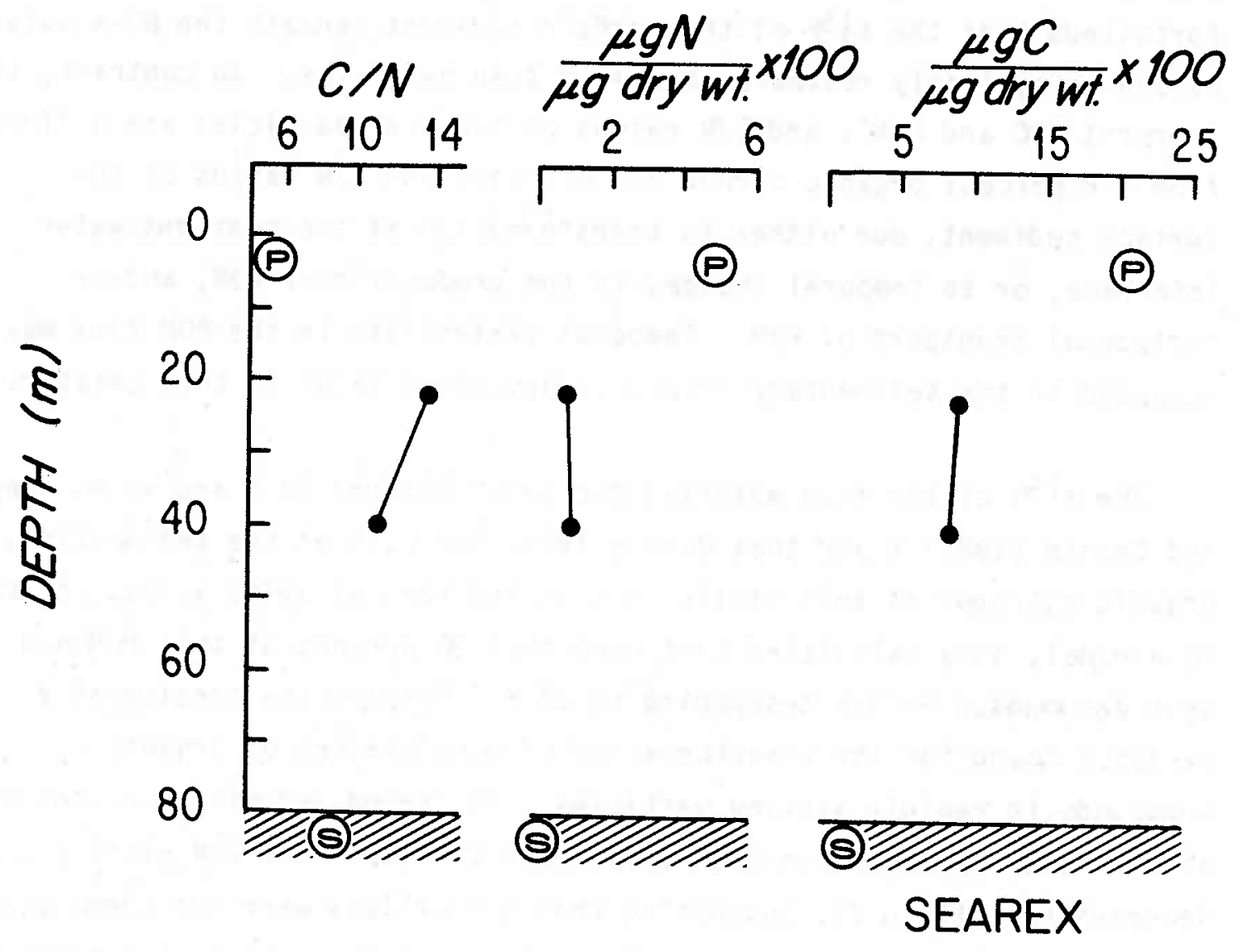


pellets. Henrichs (1980) has determined by $210 \mathrm{~Pb}$ dating that the sediments in this area appear to be accumulating at a rate of about $1 \mathrm{~cm} / \mathrm{yr}$. Thus the surface sediment sample $(0-2 \mathrm{~cm})$ represents a 2 -year average of $\delta 15 \mathrm{~N}$ of PON accumulating in the sediments. It may be fortuitous that the $\delta 15 \mathrm{~N}$ of the surface sediment beneath the $80-\mathrm{m}$ water column isotopically resembles the $40 \mathrm{~m}$ trap particles. In contrast, the "percent $P O C$ and $P O N "$, and $C / N$ ratios of the trap particles are different from the percent organic carbon and nitrogen and $C / N$ ratios of the surface sediment, due either to transformation at the sediment/water interface, or to temporal changes in the production of POM, and/or horizontal transport of POM. Temporal variability in the POM flux may be recorded in the sedimentary record as discussed later in this chapter.

The $\delta 15 \mathrm{~N}$ of the trap material decreased between $22 \mathrm{~m}$ and $40 \mathrm{~m}$. Lee and Cronin (1982) found that during 1978, the bulk of the sedimenting organic nitrogen at this station was in the form of amino acids. Based on a model, they calculated that more than 80 percent of this PON had been decomposed before descending to $14 \mathrm{~m}$. Despite the considerable evidence found for the transformation of many classes of organic compounds in rapidly sinking particles, the carbon and nitrogen contents of the fecal pellets from both traps were similar. The $\mathrm{C} / \mathrm{N}$ ratio did decrease from 14 to 11 , suggesting that the pellets were not chemically identical. In addition, carotenoid analyses of these particles suggest that rapid transformations of this specific class of organic compounds had al so occurred (Repeta, 1982).

There is insufficient information to determine whether the POM was subject to isotopic alteration during descent through the water column. The difference in $\delta 15 \mathrm{~N}$ between POM collected at $14 \mathrm{~m}$ and $20 \mathrm{~m}$ may be due to isotopic variability in the production of anchovy fecal pellets rather than the effects of microbial remineralization. Regardless, the large difference between the $\delta^{15} \mathrm{~N}$ of the plankton and the sediments suggests that the POM generated by biological productivity in the euphotic zone undergoes 1 arge changes in isotope content before it is 
buried in the sediments. Whether this is the result of fecal-pellet packaging or diagenesis in the surface sediments cannot be resolved from these data.

\section{Station A:}

The PON caught in Niskin bottles at Station A exhibited a large range in $\delta^{15} \mathrm{~N}\left(+4\right.$ to $\left.+15^{\circ} / 00\right)$. In comparison, the $\delta^{13} \mathrm{C}$ of the particles was relatively constant $(-22$ to $-18 \%$ ) (Figure $3-22)$. From 0 to $30 \mathrm{~m}$, the particulate matter on the filters was composed mostly of a green pennate diatom ( $100 \mu \mathrm{m}$ long) and a layer of amorphous yellow-brown matter. Other than a few cells of Coscinodiscus, no other cells larger than $>10 \mu \mathrm{m}$ were observed. No fecal pellets were present on the filters. The relative amounts of the two diatoms and amorphous yellow-brown matter were variable with depth. Below $20 \mathrm{~m}$ where oxygen concentrations were less than $0.02 \mathrm{ml} / 1$ and hydrogen sulfide was present, the dark green coloration of the pennate diatoms was absent and the centric diatoms were absent. From 40 to $45 \mathrm{~m}$, only seemingly amorphous yel low-brown matter was found on the filters.

The POM from the surface waters $(0-10 \mathrm{~m})$ was isotopically similar to that caught with a plankton net. The particles were markedly enriched in $15_{\mathrm{N}}$ as compared to all the other POM collected in this study (except for the plankton at Station SEAREX). These high values are comparable to those observed by Saino and Hattori (1980) in POM $\left(+13^{\circ} / 00\right)$ from below $1000 \mathrm{~m}$ in the northeastern Indian Ocean.

As shown in Figure 3-24, the PON and POC concentrations decreased from 0 to $25 \mathrm{~m}$. Below $25 \mathrm{~m}$, where oxygen concentrations were below the detection 1 imit $(<0.02 \mathrm{~m} 1 / 1)$, the PON and POC concentrations increased with increasing depth, reaching maxima at 35 and $40 \mathrm{~m}$, respectively. The $\mathrm{C} / \mathrm{N}$ ratios also decreased from 14 at the surface to lower values (3.5 to 9.0) in the deeper waters (Figure 3-23).

The PON and POC concentration maxima, and $10 \mathrm{~W} C / \mathrm{N}$ ratios in the 
Figure 3-22.

Peru Upwelling Area

Station $A: \delta^{15}$ and $\delta^{13} \mathrm{C}$ of $\mathrm{Plankton}, \mathrm{POM}$, and Surface Sediments $(0-2 \mathrm{~cm})$ 


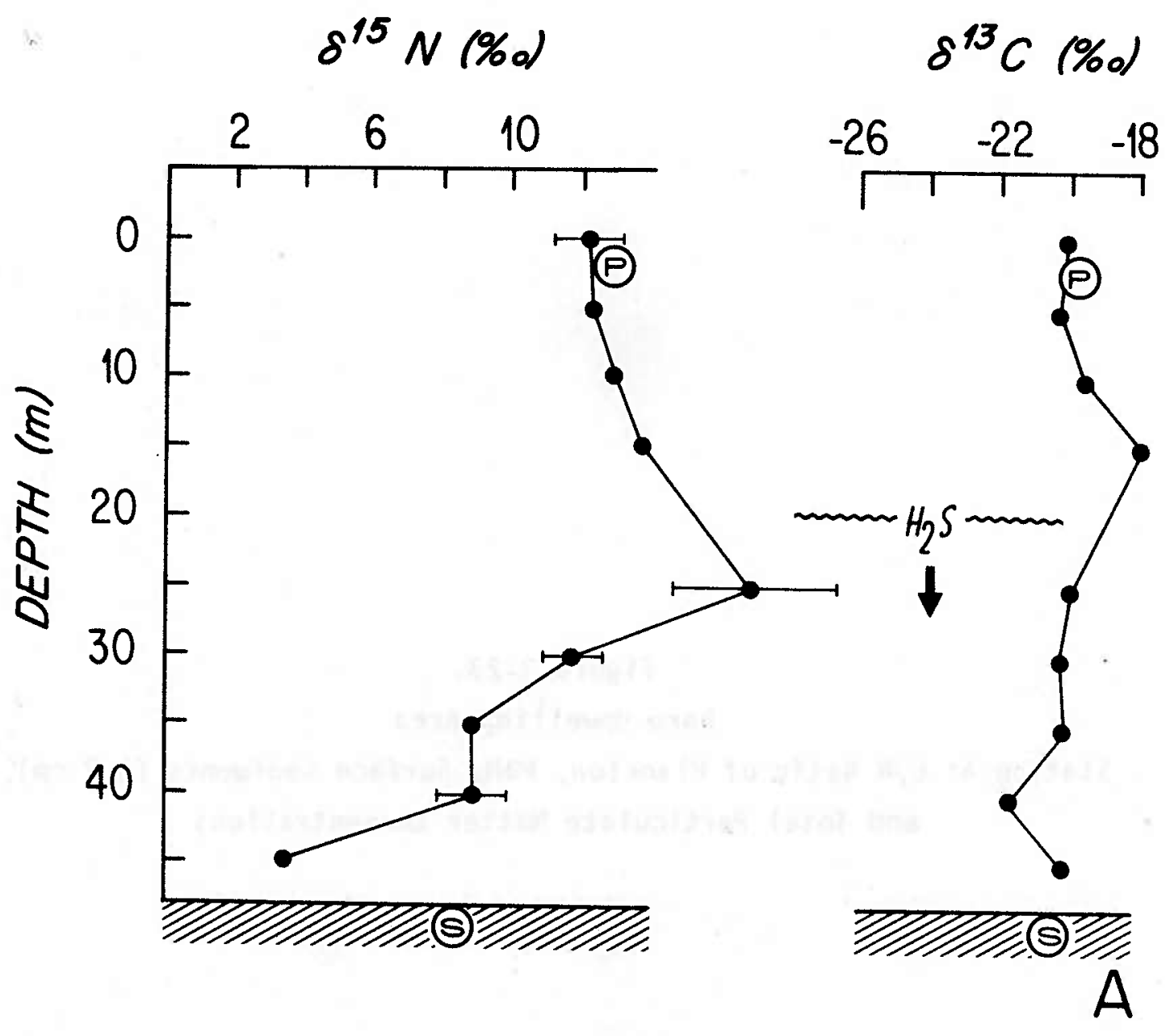


$-151-$

Figure 3-23.

Peru Upwelling Area

Station A: C/N Ratio of Plankton, POM, Surface Sediments $(0-2 \mathrm{~cm})$, and Total Particulate Matter Concentrations 


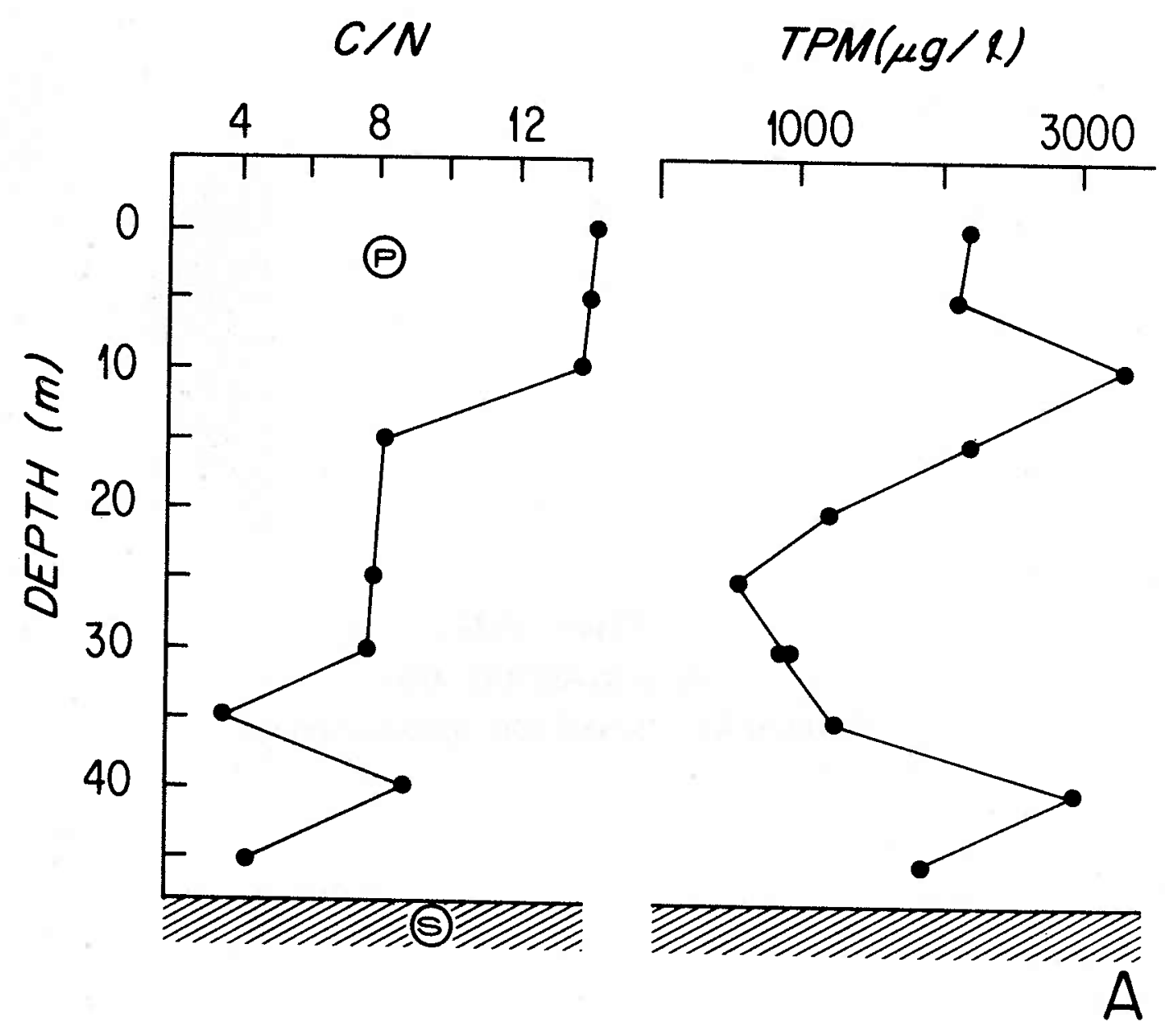


$-153-$

Figure 3-24.

Peru Upwelling Area

Station A: PON and POC Concentrations 


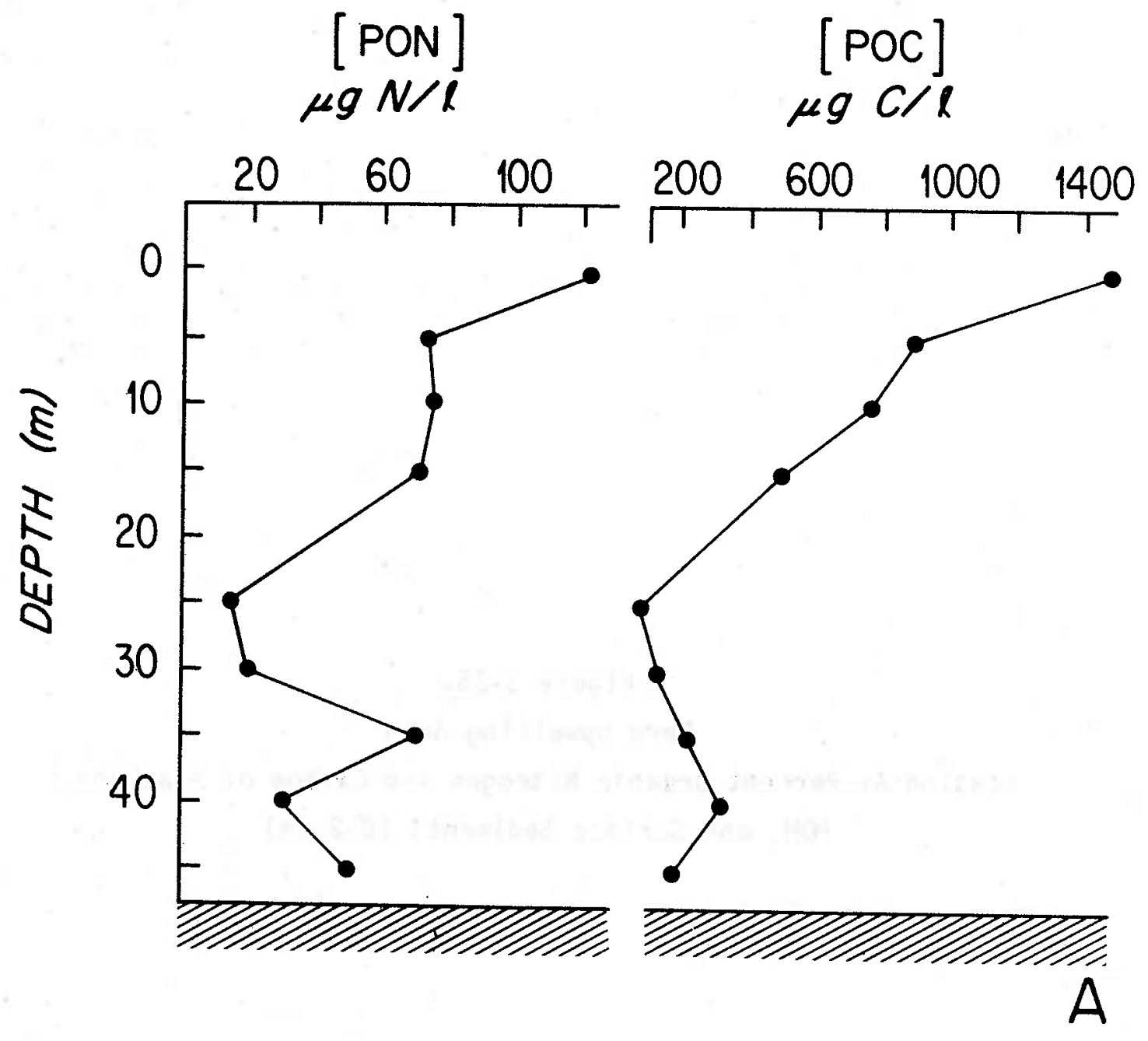


$-155-$

Figure 3-25.

Peru Upwelling Area

Station A: Percent Organic Nitrogen and Carbon of Plankton, POM, and Surface Sediments $(0-2 \mathrm{~cm})$ 

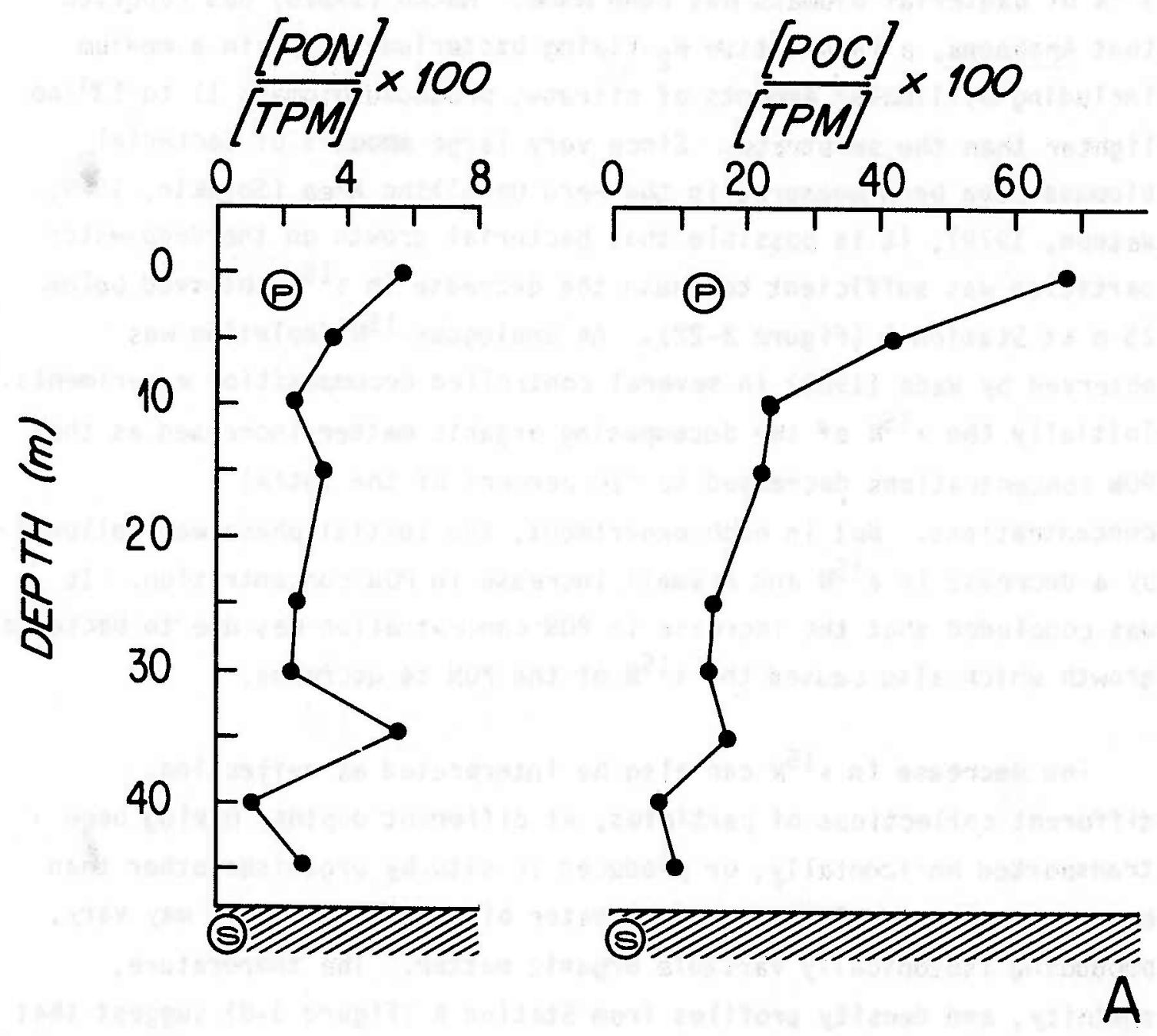
anoxic waters of this short water column might have been caused by bacterial synthesis of organic matter. Only one measurement of the $\delta^{15} \mathrm{~N}$ of bacterial biomass has been made. Macko (1982b) has reported that Anabaena, a facultative $\mathrm{N}_{2}$-fixing bacterium, grown in a medium including millimolar amounts of nitrate, produced biomass 11 to $13^{\circ} / 00$ lighter than the substrate. Since very large amounts of bacterial biomass have been measured in the Peru Upwelling Area (Sorok in, 1979; Watson, 1979), it is possible that bacterial growth on the deep-water particles was sufficient to cause the decrease in $\delta^{15_{N}}$ observed below $25 \mathrm{~m}$ at Station A (Figure 3-22). An analogous $15 \mathrm{~N}$ depletion was observed by Wada (1980) in several controlled decomposition experiments. Initially the $\delta^{15} \mathrm{~N}$ of the decomposing organic matter increased as the PON concentrations decreased to $\sim 20$ percent of the intial concentrations. But in each experiment, the initial phase was followed by a decrease in $\delta^{15} \mathrm{~N}$ and a small increase in PON concentration. It was concluded that the increase in PON concentration was due to bacterial growth which also caused the $\delta^{15} \mathrm{~N}$ of the PON to decrease.

The decrease in $\delta^{15} \mathrm{~N}$ can also be interpreted as reflecting different collections of particles, at different depths, having been transported horizontally, or produced in situ by organisms other than bacteria. Alternatively, surface-water biological activity may vary, producing isotopically variable organic matter. The temperature, salinity, and density profiles from Station A (Figure 3-8) suggest that the same water mass was present at least to $30 \mathrm{~m}$. The $5^{\circ} \mathrm{C}$ decrease in temperature below $30 \mathrm{~m}$ and the 1 ow $\delta^{15} \mathrm{~N}$ of POM at $45 \mathrm{~m}$ suggest the presence of a different water mass which contained a different assemblage of particles having a different isotope content than the particles in the overlying water mass. On the other hand, this sample was collected from anoxic waters where hydrogen sulfide was detected. Therefore, it was subject to bacterial attack similar to that experienced by the rest of the PON collected in the anoxic zone, but perhaps for a different length of time. 
Due to the low oxygen concentrations and lack of light below $20 \mathrm{~m}$, it is unlikely that any biological activity other than anaerobic heterotrophic and chemosynthetic bacterial metabolism was important below this depth (Judkins, 1980). In addition, the visual inspection of the filters revealed the absence of zooplankton. Only two species of phytoplankton were present, their numbers, as well as state of preservation, decreasing with increasing depth. There was no evidence for different organisms selectively inhabiting mid-water depth intervals.

Temporal and spatial variability in the $\delta^{15} \mathrm{~N}$ of phy toplankton may be the cause of the 1 arge range in the $\delta^{15} \mathrm{~N}$ of POM. If 1 arge changes do occur, the $\delta^{15} \mathrm{~N}$ of particles found throughout the water column may be reflecting changes in isotope fractionation associated with nutrient assimilation by phytoplankton. The influence of environmental factors on isotopic fractionation has been discussed in the Introduction. It has been shown that changes in species composition are not necessary to cause a change in the $\delta^{15} \mathrm{~N}$ of the plankton biomass (Wada and Hattori, 1976). Though the $\delta^{15} \mathrm{~N}$ of plankton from the two inshore stations, Stations $A$ and SEAREX, were similar, plankton collected near Station $A$ by Reimers (1981) in April of 1977 was $+7.5 \%$, much lower than that found in 1981. So it is 1 ikely that the $\delta^{15} \mathrm{~N}$ of the surface-water POM is variable.

The 1 arge decreases in POC and PON concentrations with increasing depth suggest that mineralization of organic matter did occur. In the anoxic waters, anaerobic bacterial metabolism must have been occurring. As mentioned earlier in this chapter, microbial numbers and respiration rates are very high in the Peru Upwelling Region, such that bacteria and protozoa comprise a significant portion of the biomass and are important in maintaining nutrient concentrations via microbial remineralization of POM. The bacterially-mediated processes by which degrading particles become depleted in ${ }^{15} \mathrm{~N}$ are considered in detail in the following discussion section. 


\section{Station B:}

The particles collected at Station $B$ al so exhibited a large range in $\delta^{15} \mathrm{~N}$, varying from $-2 \%$ at the surface to a maximum of $+10 \%$ at $40 \mathrm{~m}$. Except for two samples from 40 and $50 \mathrm{~m}$, the $\delta^{13} \mathrm{C}$ of the particles was relatively constant, varying from -18 to $-21^{\circ} / 00$ (Figure 3-26).

The composition of the particles was markedly different from that at Station A, having a greater variety of phytoplankton. Though a few zooplankton were present on some of the filters, most of the biomass was composed of small ( $10 \mu \mathrm{m}$ diameter) circular green phytoplankton with a small contribution from Coscinodiscus. Below $40 \mathrm{~m}$, the filters were sparsely covered with fragments of phytoplankton and zooplankton. A few (6) $100 \mu \mathrm{m}$ long fecal pellets were collected at $40 \mathrm{~m}$. The TPM, POC and PON concentrations decreased with increasing depth (Figures 3-27 and 3-28). The sharpest change occurred between 20 and $30 \mathrm{~m}$, where oxygen concentrations decreased from 3.8 to $1.6 \mathrm{ml} / 1$.

Except for the surface sample, the $\delta^{15} \mathrm{~N}$ of the particles between 10 and $40 \mathrm{~m}$ resembled that of the plankton, which comprised most of the identifiable material on the filters. The $\delta^{15} \mathrm{~N}$ of plankton from Station B was 2 to $3 \%$ lower than that from Station A, reflecting the greater stability of the water column (Figure 3-11) which inhibited

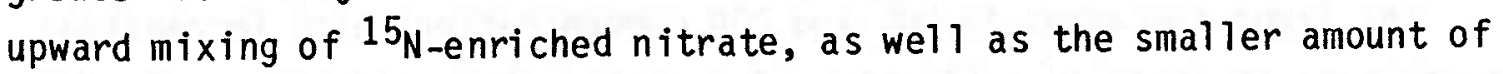
denitrification, and higher DIN concentrations at this station. Below $40 \mathrm{~m}$, the particles collected in the suboxic region $\left(0.1 \mathrm{ml} 0_{2} / 1\right)$ of the water column were considerably $15_{\mathrm{N}}$-depleted $\left(+2.5\right.$ to $\left.+7.5^{0} / 00\right)$ compared to those from the oxic waters $(+8$ to $+10 \% / 00)$. As at Station $A$, the deepest POM was markedly depleted in $15 \mathrm{~N}$ with respect to the rest of the particles in the water column and the surface sediments just $10 \mathrm{~m}$ below.

The extremely 1 ow $\delta^{15} \mathrm{~N}\left(-1.8,-3.3^{\circ} / 00\right)$ found at the surface represents the lowest value yet reported for plankton not composed of 
Figure 3-26.

Peru Upwelling Area

Station $\mathrm{B}$ : $\delta^{15_{\mathrm{N}}}$ and $\delta^{13} \mathrm{C}$ of Plankton, POM, and Surface Sediments $(0-2 \mathrm{~cm})$ 


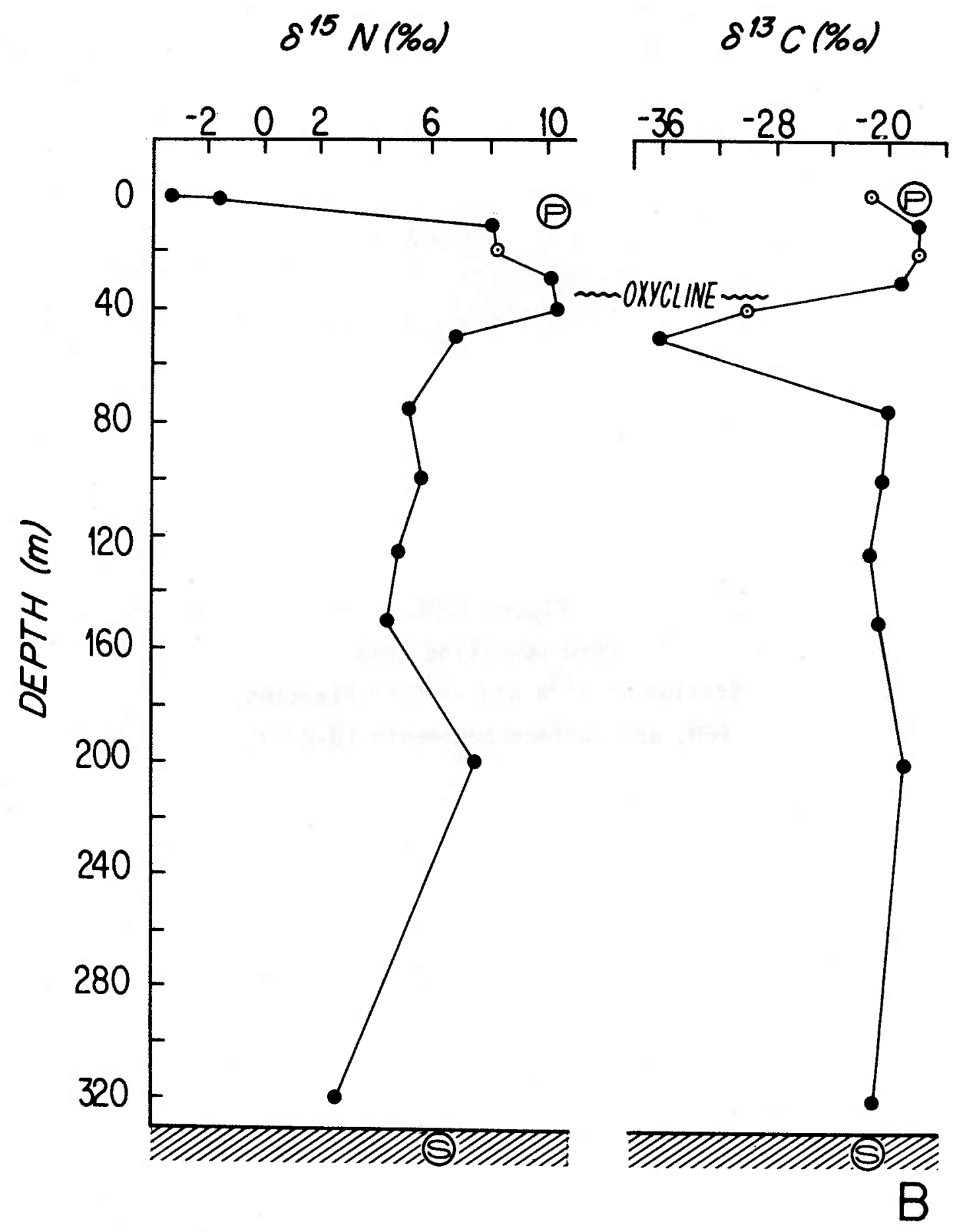


-162-

Figure 3-27.

Peru Upwelling Area

Station B: C/N Ratio of Plankton,

POM, and Surface Sediments $(0-2 \mathrm{~cm})$

and Total Particulate Matter Concentrations 


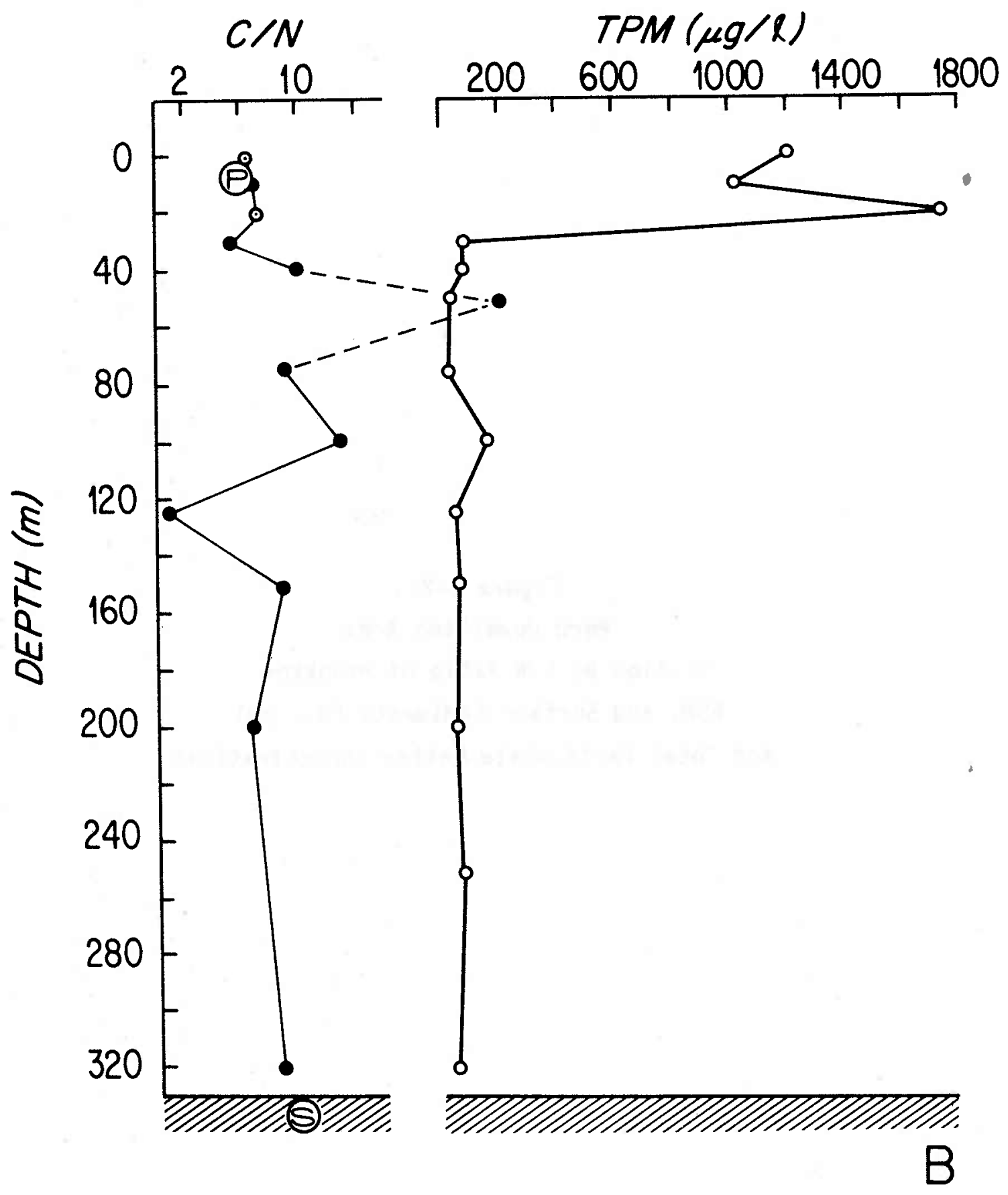


Figure 3-28.

Peru Upwelling Area

Station B: PON and POC Concentrations 


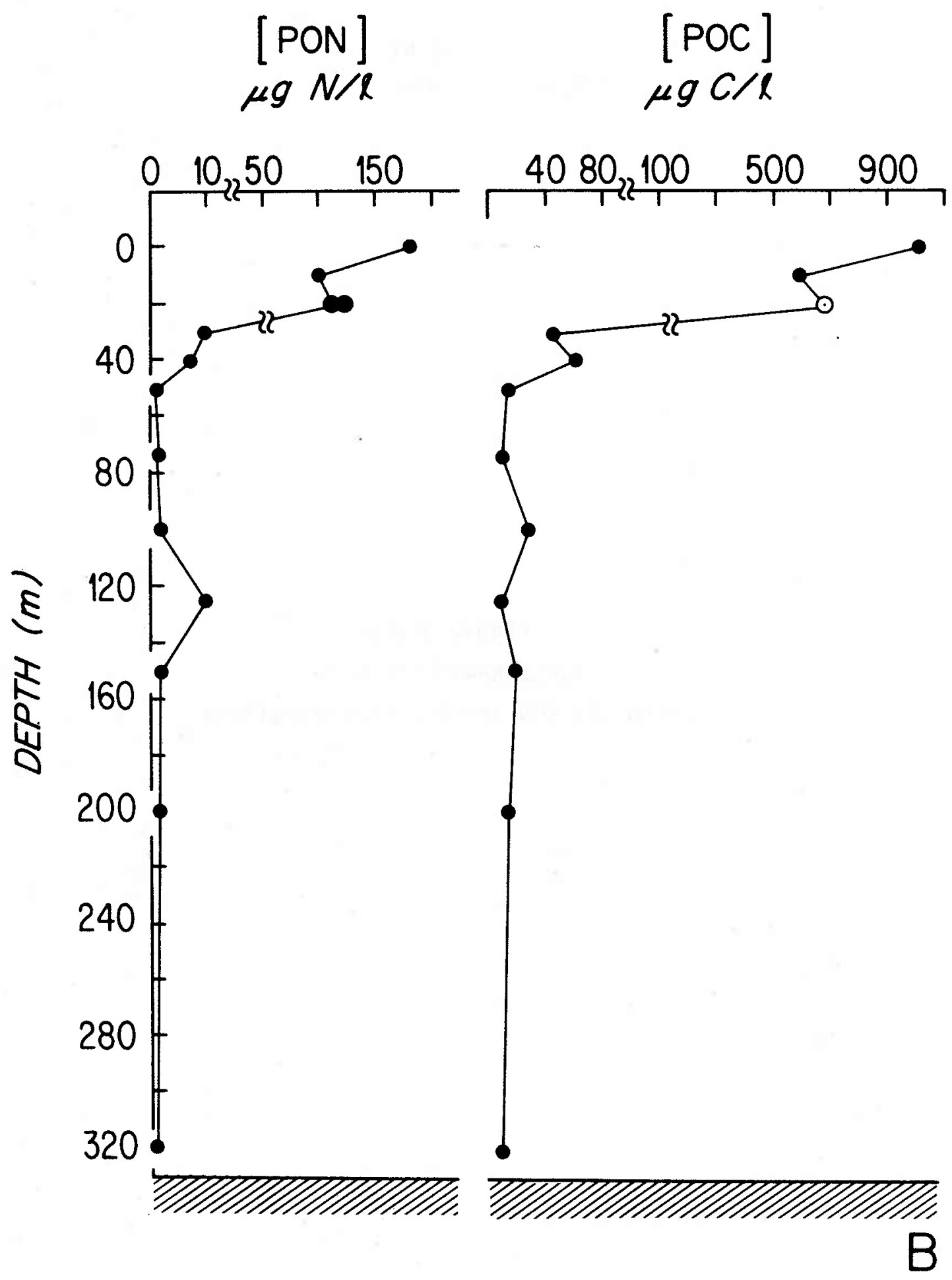


$-166-$

Figure 3-29.

Peru Upwelling Area

Station B: Percent Organic Nitrogen and Carbon of Plankton, POM, and Surface Sediments $(0-2 \mathrm{~cm})$ 

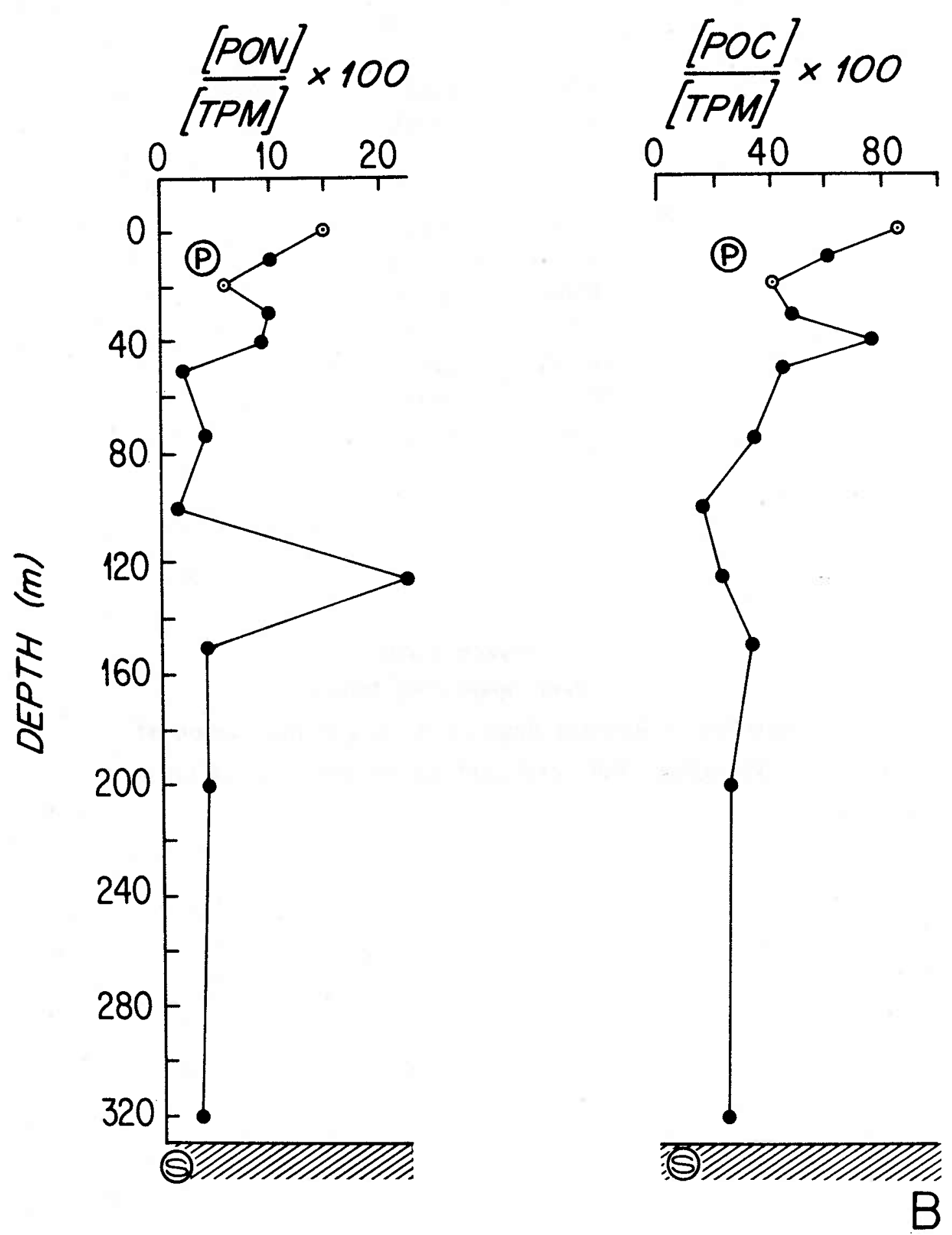
Trichodesmium, a blue-green $\mathrm{N}_{2}$-fixing alga. The values represent results obtained by analyzing both halves of the filter separately. In contrast to the $1.5 \%$ difference in $\delta^{15} \mathrm{~N}$ found between the filter halves, the $\delta^{13} \mathrm{C}, \mathrm{C} / \mathrm{N}$ ratios, $\mathrm{PON}$ and $\mathrm{POC}$ concentrations were within the analytical error of the method. There is no evidence from the

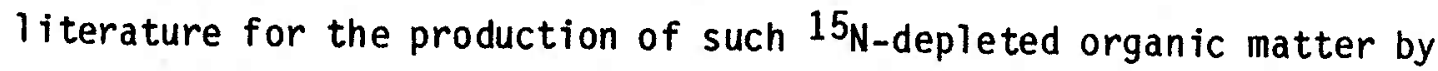
phy toplankton or zooplankton. The low $\delta^{15_{N}}$ of bacterial biomass (11 to $13^{\circ} / 00$ lower than the substrate) reported by Macko (1982b) suggests

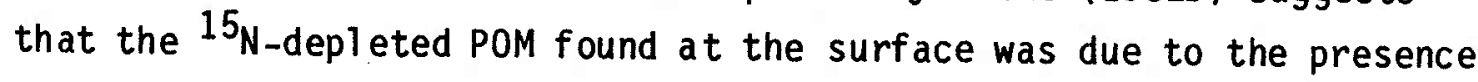
of bacterial biomass or other organisms which consumed the bacteria.

Though bacterial numbers are very 1 arge in the Peru Upwelling Region, it is unlikely that their intact biomass alone was the cause of the $15_{\mathrm{N}}$ depletion unless their numbers were two orders of magnitude higher than previously reported at the sea surface, where PON concentrations were $175 \mu \mathrm{g} \mathrm{N} / \mathrm{l}$. On the other hand, if the fractionation by the bacteria present at this station was 1 arger than that achieved by Anabaena, 1 arge numbers of bacteria need not have been present. Alternatively, if bacterial biomass was a major contributor to the large DON pool (Figure 3-9) and the DON was isotopically similar to its bacterial source, assimilation of this nitrogen by phytoplankton may have produced the large concentration of $15 \mathrm{~N}$-depleted POM at the surface. This requires that the DON at the surface be isotopically different from deeper DON. As discussed later in this chapter, variability in the $\delta^{15} \mathrm{~N}$ of DON is possible.

One specially interesting point about this $15_{\mathrm{N}}$-depleted POM is that just $10 \mathrm{~m}$ below it the POM had a $\delta^{15} \mathrm{~N} 10^{\circ} / 00$ higher. If the surface sample was the result of a bloom, its anomalous $\delta^{15} \mathrm{~N}$ should be

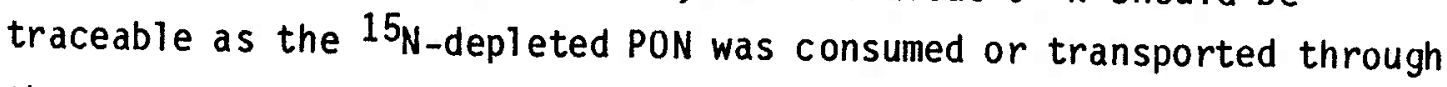
the water column. Since this was not the case, either the surface-water particles did not make a significant contribution to the particles below, or a bloom was just getting underway at the time the particles were collected. 
The decrease of $\delta^{15} \mathrm{~N}$ in the particles below $40 \mathrm{~m}$ suggests that the process(es) which gave rise to the low oxygen concentrations below this depth (Figure $3-9$ ) al so caused ${ }^{15} \mathrm{~N}$ depletion in the PON. As at Station $A$, there was no evidence that filters from different depths contained wholly different collections of particles, for example: zooplankton restricted to specific depths, or particles which collected at a density discontinuity.

In contrast to the $\delta^{15} \mathrm{~N}$, the $\delta^{13} \mathrm{C}$ of the POM was relatively constant, except for the 40 - and $50-\mathrm{m}$ samples which were extraordinarily ${ }^{13} \mathrm{C}$ depleted $(-30.0$ and $-36.5 \%)$. Comparable ${ }^{13} \mathrm{C}$ values have been reported only for bacterial biomass (Degens et al., 1968). These workers found that Nitrosocystis oceanus, a marine nitrifier, when grown in the laboratory, had a $\delta^{13} \mathrm{C}$ of -35.4 to $-35.9^{\circ} / 00$ with respect to PDB. Though the high $\mathrm{C} / \mathrm{N}$ ratio (24) of the $50-\mathrm{m}$ sample suggested petroleum contamination, values for the $\delta^{13} \mathrm{C}$ of petroleum $(-23$ to $\left.-32^{\circ} / 00\right)$ (Yeh, 1981) are not 1 ow enough to account for the ${ }^{13} \mathrm{C}$ depletion observed.

Thus the effect of a significant bacterial component on the $\delta^{13} \mathrm{C}$ of POM must be considered. The $\delta^{15} \mathrm{~N}$ of the particles from 40 to $50 \mathrm{~m}$ do not show the $15 \mathrm{~N}$ depletion hitherto suggested for bacterial biomass. Therefore the POM may have been composed of organisms which had consumed bacteria, as 1 ittle fractionation of $\delta^{13} \mathrm{C}$ occurs in the food chain (DeNiro and Epstein, 1978). Since the $\delta^{13} \mathrm{C}$ minimum did not coincide with the primary nitrite maximum $(20 \mathrm{~m})$, it seems unlikely that the organisms at 40 to $50 \mathrm{~m}$ were nitrifying bacteria, though Ward et al. (1982) have found constant concentrations of nitrifiers throughout the upper water column off the coast of California, i.e. there was no correlation of bacterial numbers with nitrifying activity.

\section{Station C:}

As discussed earlier in this chapter, the low particle concentrations in the water column of Station $C$ made it impossible to collect large 
$-170-$

Figure 3-30.

Peru Upwelling Area

Station C: $\delta^{15} \mathrm{~N}$ and $\delta^{13} \mathrm{C}$ of $\mathrm{Pl}$ ankton, POM, and Surface Sediments $(0-2 \mathrm{~cm})$ 


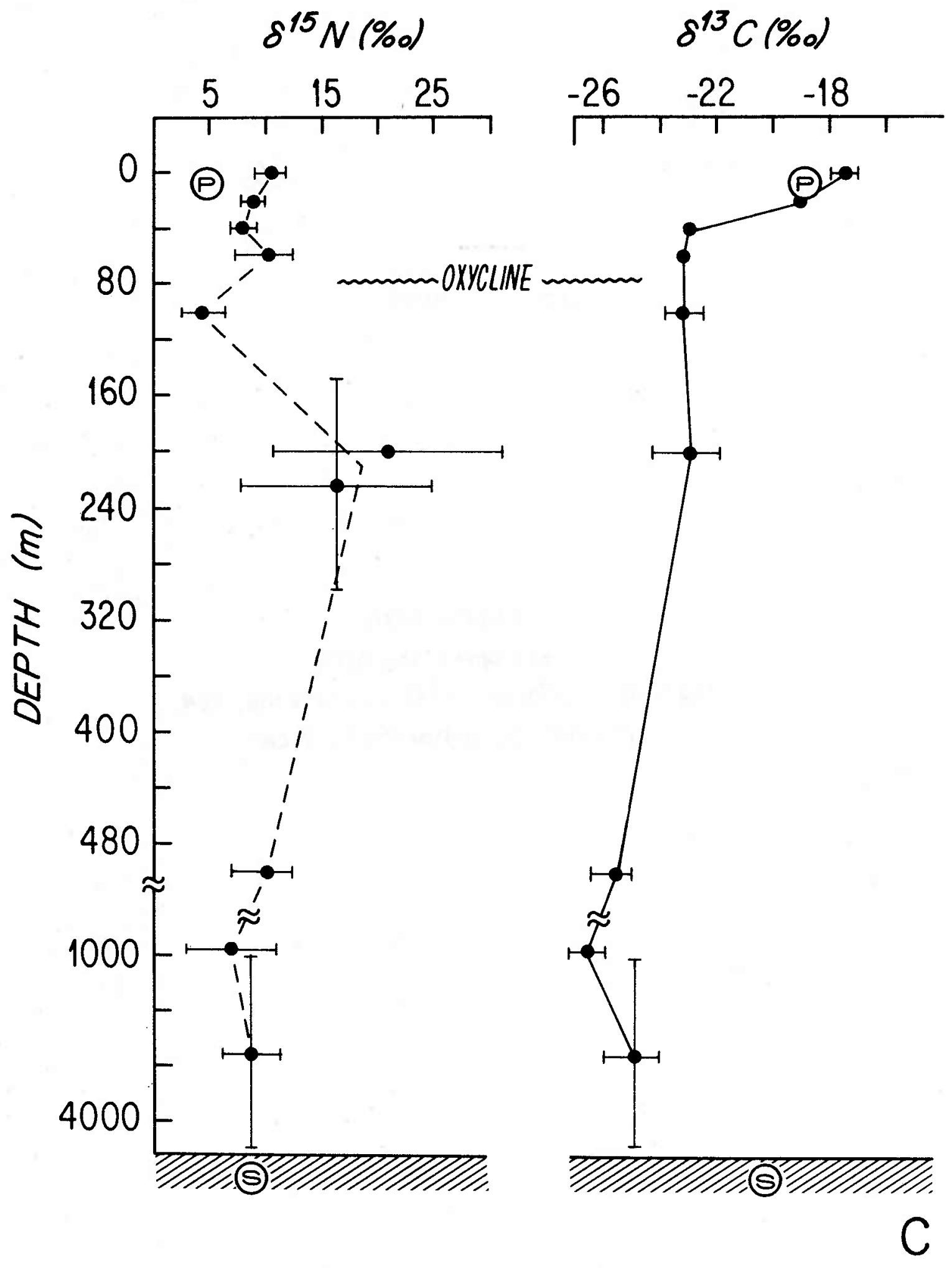


Figure 3-31.

Peru Upwelling Area

Station C: C/N Ratio of Plankton, POM, and Surface Sediments $(U-2 \mathrm{~cm})$, and Total Particulate Matter Concentrations 


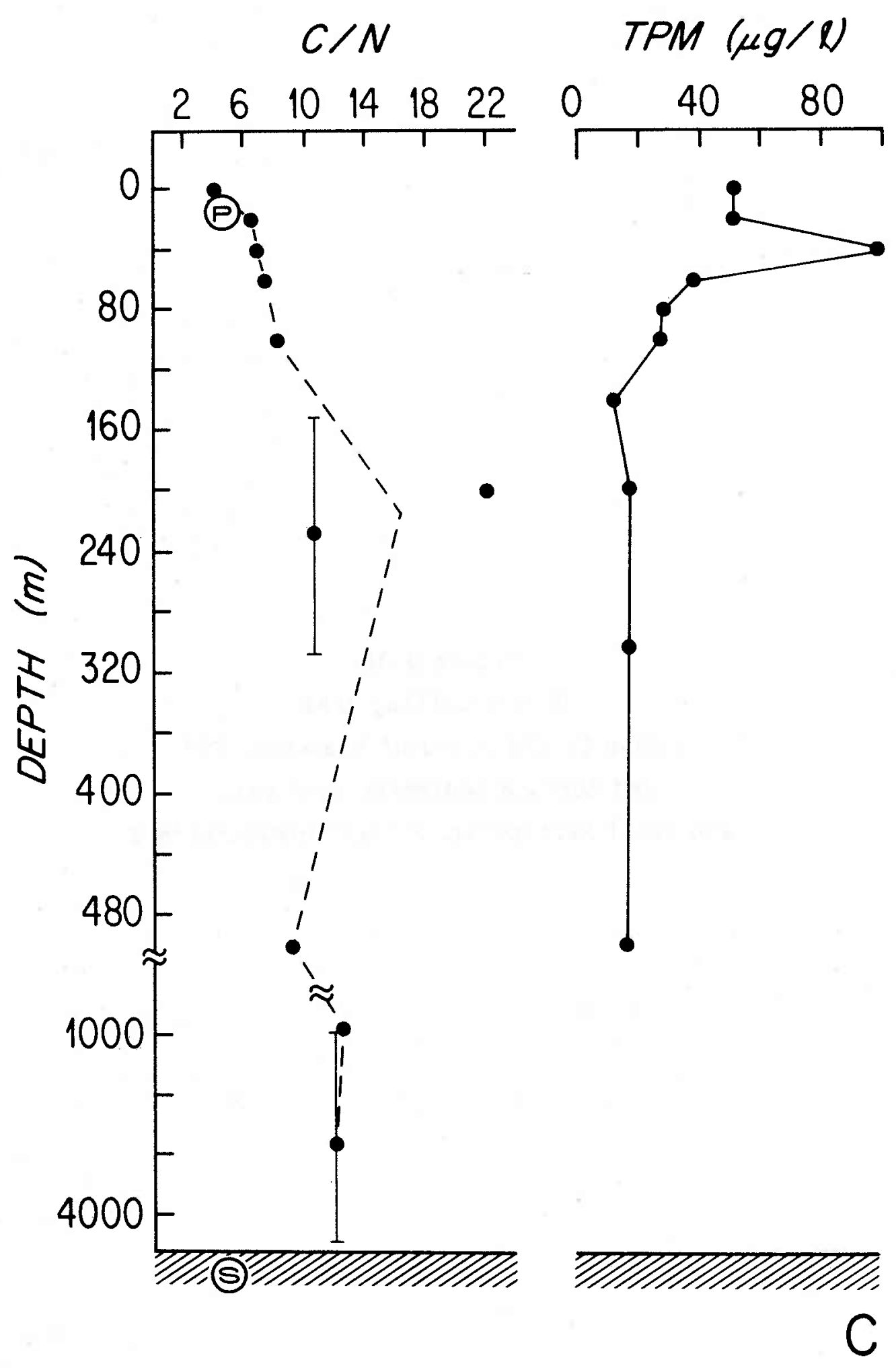


Figure 3-32.

Peru Upwelling Area

Station C: PON and POC Concentrations 

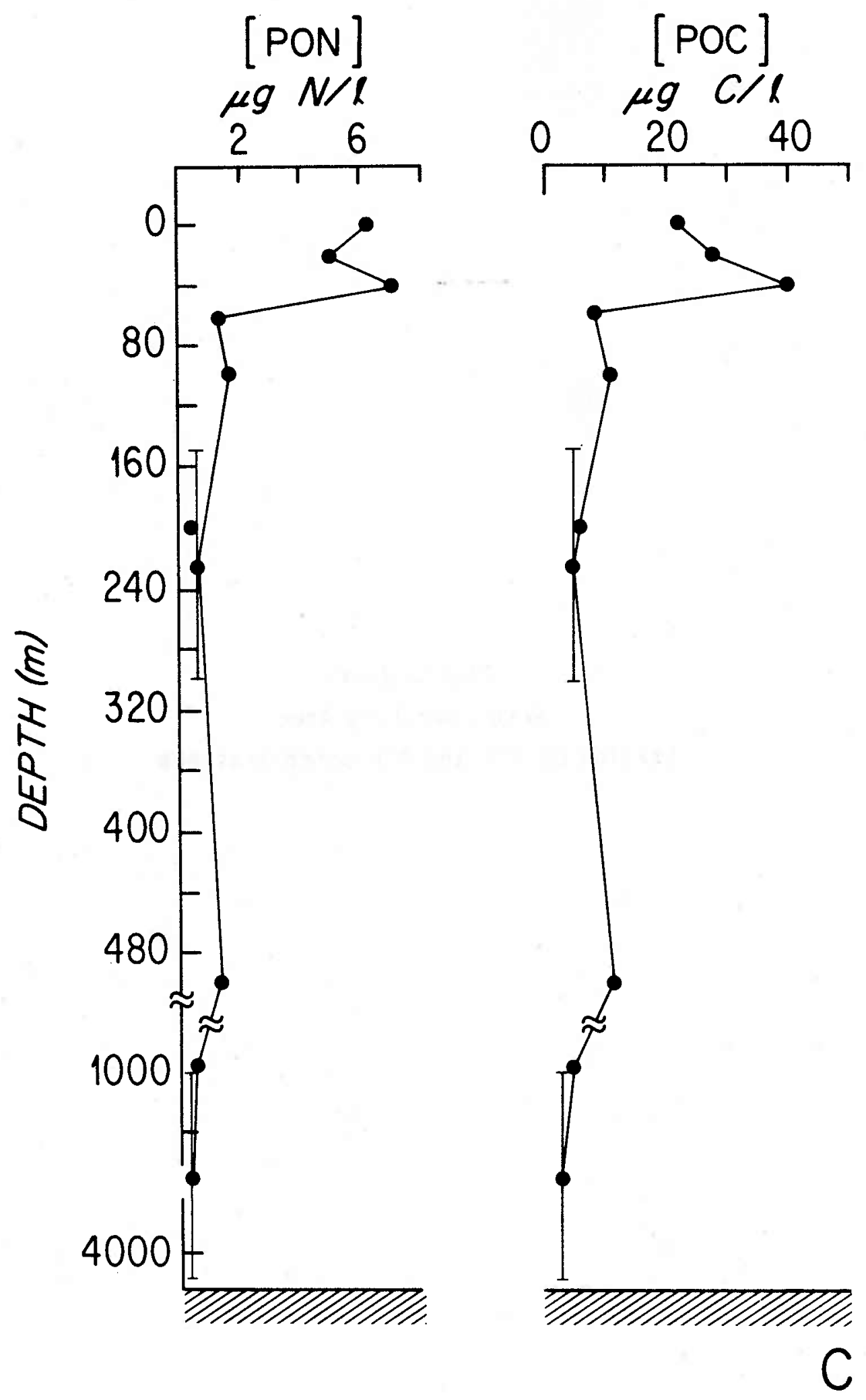
Figure 3-33.

Peru Upwelling Area

Station C: Percent Organic Nitrogen and Carbon of Plankton, POM, and Surface Sediments $(0-2 \mathrm{~cm})$ 
$-177-$

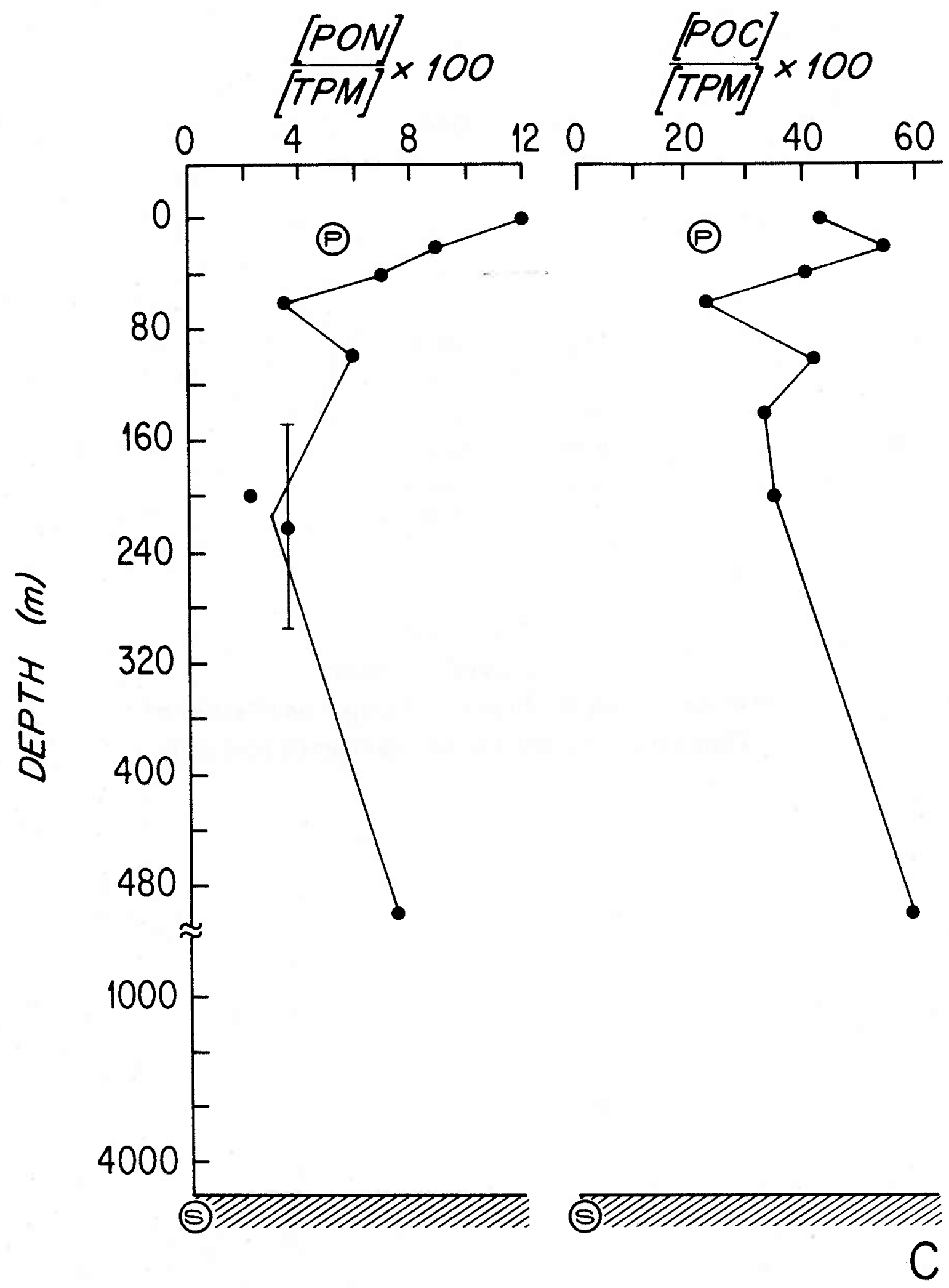


amounts of POM by the on-deck filtration system. Below $100 \mathrm{~m}$, the sample sizes were comparable to the double-tube combustion blank and thus the error bars on the $\delta^{15} \mathrm{~N}$ and $\delta^{13} \mathrm{C}$ profiles are very 1 arge. (See APPENDIX II for analytical details). Samples from 150 and $300 \mathrm{~m}$ were combined in hopes of obtaining a more certain $\delta 15 \mathrm{~N}$ value for the mid-water particles. The same thing was done with the samples from 1000 , 2500 and $4500 \mathrm{~m}$. As is clear from the $\delta 15_{\mathrm{N}}$ profile (Figure 3-30) these efforts were not too successful. It is doubtful that any variation in $\delta^{15} \mathrm{~N}$ of POM from below $100 \mathrm{~m}$ can be identified, though it is evident that the $\delta 15 \mathrm{~N}$ of the POM was greater than $+50 \%$. Al so, it appears that the $\delta 15 \mathrm{~N}$ of the deep-water particles resembles that of the surface sediments. The composition of the particles collected at Station $C$ was markedly different from that found at the preceding stations. Most notable was the large diversity of particles. From 0 to $80 \mathrm{~m}$, zooplankton (amphipods and euphausiids) comprised the bulk of the biomass, though some phytoplankton were present. The 20 -m sample was notable for its great quantity of tintinnids. Below $80 \mathrm{~m}$, the material on the filters was mostly crustacean parts, fecal pellets, and small unidentifiable green splotches.

In contrast to the preceding stations, the $\delta 15 \mathrm{~N}$ of the $\mathrm{plank}$ ton catch $(+4.90 \% 0)$ did not resemble that of the surface POM $(+7$ to 100/00) (Figure 3-30) probably due to the presence of a gelatinous matrix in the plankton tow catch. The $\delta 15 \mathrm{~N}$ of the surface POM reflected the presence of zooplankton which were noticeably abundant on the filters. At $40 \mathrm{~m}$, maxima in TPM, POC, PON, and ammonia concentrations (Figures $3-31,3-32$, and 3-13) suggested that some biological process, ammonification, nitrification, and/or plankton excretion, prevailed at this depth. Below $200 \mathrm{~m}$, the $\delta^{13} \mathrm{C}$ of the particles ranged from -23.8 to $-26.40 \%$. These mid-water and deep-water ${ }^{13} \mathrm{C}$ values are comparable to those measured in the Atlantic and southern Indian Oceans by Eadie et al. (1978), in the Pacific Ocean by Williams and Gordon (1970), and in the At?antic Ocean by Jeffrey et al. (1982). 
Just below the oxycline, where oxygen concentrations decreased to $0.1 \mathrm{ml} / 1$, the $\delta^{15 \mathrm{~N}}$ reached a minimum value of $+5 \%$ at $100 \mathrm{~m}$, the depth at which a small amount of denitrification was indicated by the nitrate, nitrite, and ammonia profiles (Figure $3-13$ ). Though the $\delta^{15} \mathrm{~N}$ mininmum was limited to one data point, its presence in the oxygen minimum zone is suggestive of the $10 \mathrm{~W} \delta 15_{\mathrm{N}}$ values found in the anoxic and suboxic waters of Stations $A$ and $B$.

The $C / N$ ratios of the POM increased from 5 in the surface waters to 12 in the deep waters (Figure 3-31), reflecting the presence of refractory POM at great depth in the water column. Thus it is not surprising that the $\delta^{15_{N}}$ of the deep-water POM appears to resemble that of the sediments, since little biological alteration of these degraded, nitrogen-poor particles would be expected. In contrast, the $\delta^{13} \mathrm{C}$ of the deepest particles was $5 \%$ lower than that of the underlying sediments. This situation has also been observed by other investigators (see Introduction: Carbon Isotope Geochemistry). Since the $\mathrm{C} / \mathrm{N}$ ratio of bottom-water POM was 14 and that of the sediments 5 , preferential ${ }^{12} \mathrm{C}$ loss during mineralization at the sediment/water interface must have occurred. This assumes that the bottom-water POM was representative of the POM accumulating on the seafloor.

\section{Discussion of POM Results:}

The $\delta^{15} \mathrm{~N}$ of the POM collected in the Peru Upwelling Area was extremely variable, ranging from -2 to $+17 \%$. These values represent the 1 owest and highest values for $\delta^{15} \mathrm{~N}$ in POM yet reported in the literature. In the surface waters, the POM (except at the surface at Station $B$ ) was enriched in $15_{N}$, resembling the plankton. The high $\delta^{15_{\mathrm{N}}}$ values were the result of the assimilation of $15_{\mathrm{N} \text {-enriched }}$ nitrate produced by denitrification and brought to the sea surface by upwelling at Stations SEAREX, A, and B. The degree of $15 \mathrm{~N}$ enrichment was found to be a function of the amount of denitrification that had occurred at a given site, as well as of the intensity of upwelling and of surface-water nutrient concentrations. Since ammonia concentrations were 
below $1 \mu M$, nitrate and DON were the dominant sources of nitrogen available for phy toplankton assimilation. Though measurements of the $\delta^{15_{\mathrm{N}}}$ of nitrate have been made in this area by Liu (1979), the $\delta^{15_{\mathrm{N}}}$ of DON is unknown. The $\delta^{15} \mathrm{~N}$ of POM has been observed by Wada (1980) to change as POM decomposes, suggesting that the $\delta^{15} \mathrm{~N}$ of DON may also be variable. Considering its importance in the marine environment (DON represents 30 to 60 percent of the fixed nitrogen in the water column; Sweeney et al., 1978), isotopic measurements of this nitrogen should be made.

The close resemblance of the $\delta^{15} \mathrm{~N}$ of the plankton to that of the surface POM suggests that primary production is central in determining the isotopic content of this material. Isotope enrichment effects 13 to $4 \%$ associated with increasing trophic levels were small compared to the general $15 \mathrm{~N}$ enrichment of the bulk plankton with respect to plankton collected where denitrification was not occurring. This further suggests the importance of primary production in determining the $\delta^{15} \mathrm{~N}$ of the surface POM.

Below the euphotic zone, oxygen concentrations rapidly decreased to low $(<0.1 \mathrm{ml} / 1)$ levels and, except at Station $C$, remained at these low concentrations to the seafloor. POM collected in these waters was visibly different, having a smaller diversity of particles in a much less intact state than the particles collected in the euphotic zone. The ${ }_{\delta} 15_{\mathrm{N}}$ of these particles was much more variable, ranging from +2.5 to $+17 \%$, than that of the surface-water PON. All of the particles collected at oxygen concentrations greater than $1 \mathrm{ml} / 1$ had $\delta^{15} \mathrm{~N}$ values above $+8^{\circ} / 00$ (Figure 3-34) which, as discussed earlier, is significantly higher than found in POM from non-upwelling areas (see Figure 3-15).

It is suggested that the large range in $\delta^{15} \mathrm{~N}$ found in the POM collected in anoxic and suboxic waters reflects the effect of extensive mineralization by bacteria, as do the decreases in PON and POC 
$-181-$

Figure 3-34.

Peru Upwelling Area:

${ }^{15_{\mathrm{N}}}$ of POM versus $0 x y$ gen Concentrations $(\mathrm{ml} / 1)$

(Data points connected in order of increasing depth.

The filled-in data point represents the surface sample.)

(The oxygen concentration detection 1 imit is indicated by the dashed 1 ine at $0.02 \mathrm{~m} 1 / 10_{2} .1$ 


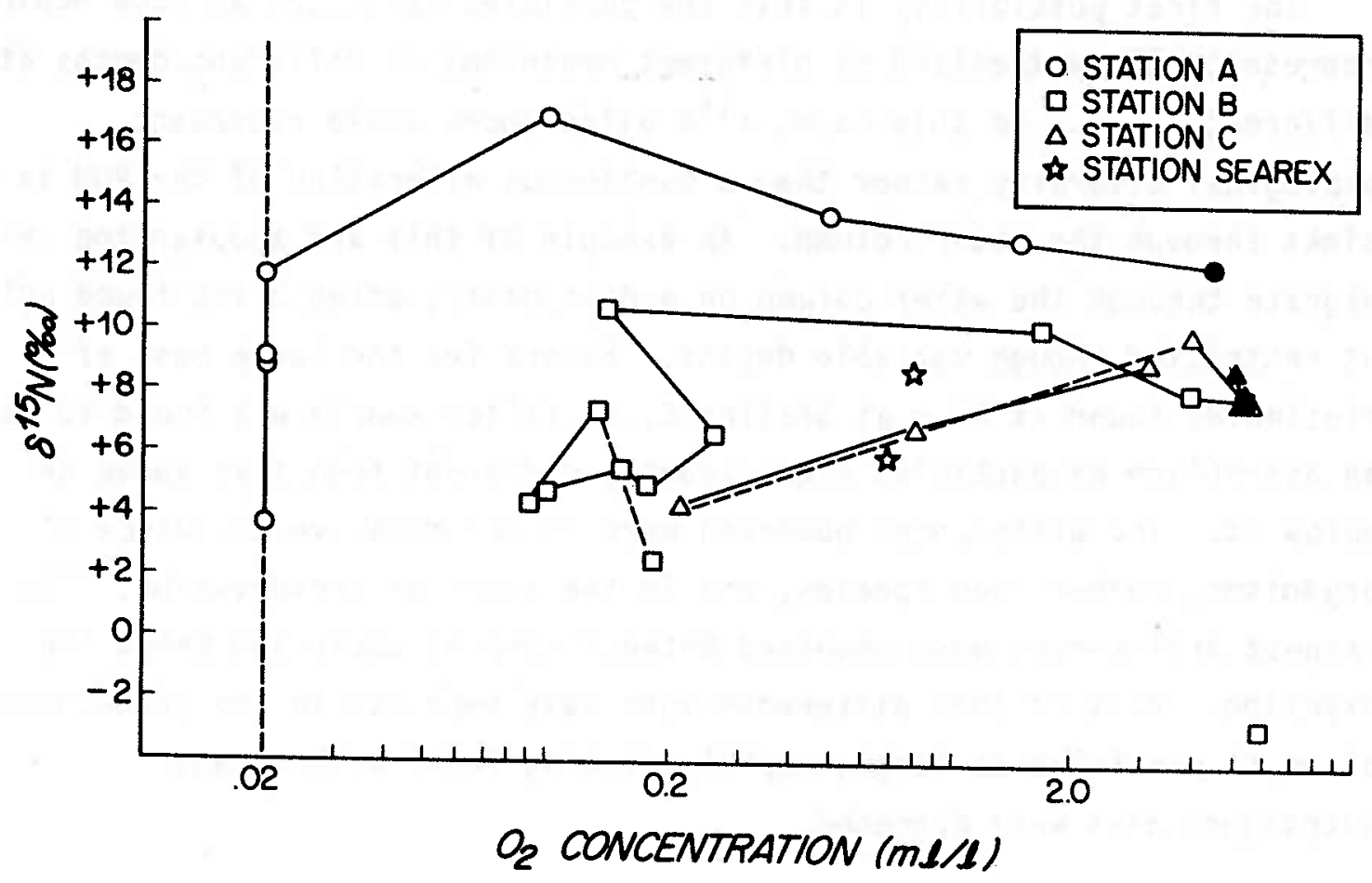


concentrations. A general decrease in $\delta^{15} \mathrm{~N}$ with increasing depth was found, suggesting a cumulative effect of anaerobic degradation. There are insufficient data to determine the exact mechanism by which this $15_{N}$ depletion is produced, but several possibilities are suggested.

The first possibility is that the particles collected at each depth represent POM synthesized by different organisms at different depths at different times. In this case, $\delta^{15} \mathrm{~N}$ differences would represent biological diversity rather than a continuous alteration of the POM as it sinks through the water column. An example of this are zooplankton which migrate through the water column on a diel basis, often being found only at restricted though variable depths. Except for the large mass of tintinnids found at $40 \mathrm{~m}$ at Station $C$, no filter sample was found to have an assemblage of particles significantly different from that above or below it. The differences observed were in the relative abundance of organisms, rather than species, and in the state of preservation. The largest differences were observed between samples above and below the oxycline. Part of this difference must have been due to the production of small particles as large, rapidly-sinking fecal pellets and macroaggregates were degraded.

Horizontal advection of particles must also be considered, since the Peru Undercurrent, which flows south at depths of 40 to $70 \mathrm{~m}$ along the shelf (Brockmann et al., 1980), has been shown to transport resuspended sediments (Reimers, 1981). Bottom nepheloid layers have al so been observed and are thought to be composed of particles transported westward off the continental shelf (Pak et al., 1980). Garfield et al. (1979) have observed that horizontal advection in the Peru Upwelling Area had an insignificant effect on the particulate protein concentrations, which represent 80 to 100 percent of the PON, even though the particles (caught in Niskin bottles) were calculated to be sinking at slow rates of 1 to $5 \mathrm{~m} /$ day. This is due to the 1 arge geographic spread of the oxygen-depleted waters. The wide-spread similarity in bottom-water oxygen and nitrogen concentrations and the unique effect of isotopic 
al teration in the suboxic waters on the $\delta^{15} \mathrm{~N}$ of POM suggest that the horizontally-advected particles are similar to that of particles which have not been horizontally advected, differing mainly in the length of time spent in the poorly-oxygenated waters found in the Peru Undercurrent. If anything, the $\delta 15 \mathrm{~N}$ of the horizontally-advected particles should reflect the effects of extended anaerobic microbial mineralization, rather than differences in primary productivity, on the ${ }_{\delta}^{1} 1 \mathrm{~N}_{\mathrm{N}}$ of the surface-water POM.

PON, POC concentrations and "percent PON and POC" values decrease with increasing depth, as would be expected for steadily degrading particles. It is suggested that microbial mineralization of POM in the suboxic region of the water column also modified the isotopic content of the particles causing the $\delta 15 \mathrm{~N}$ of POM to decrease with increasing depth. It is expected that surface POM is $15_{N}$ enriched to an extent distinguishable from POM from the suboxic zone all along the coast of Peru, since denitrification, the ultimate cause of the $15 \mathrm{~N}$ enrichment of the surface-water POM and the $15 \mathrm{~N}$-depletion of deep-water POM, occurs from $5^{\circ} \mathrm{S}$ to $15^{\circ} \mathrm{S}$.

The $15 \mathrm{~N}$-enrichment of the surface POM may be the result of isotopic fractionation during remineralization, i.e. the bacteria are selectively remineralizing the $15 \mathrm{~N}$, leaving behind $15 \mathrm{~N}$-depleted refractory PON. There is no evidence for this either in the literature or from theoretical considerations of kinetic isotope fractionation. What is more likely is that bacteria are selectively degrading the more labile organic nitrogen compounds which are variably enriched in $15 \mathrm{~N}$. A similar process has been postulated by Degens (1969), whereby sediments become ${ }^{13} \mathrm{C}$-depleted via 1 oss of the ${ }^{13} \mathrm{C}$-enriched $\alpha$-carboxy 1 moiety in amino acids. There are two pieces of evidence to support this hypothesis. First, Macko (personal communication) has observed that different sedimentary amino acids have different $\delta 15_{\mathrm{N}}$ values, varying by several permil. These differences are the result of the different anabolic pathways which generate the amino acids. Macko (1982a) also 
found that during deamination, the ${ }^{15} \mathrm{~N}$-depleted amine is preferentially lost, as would be expected from kinetic considerations.

Secondly, 1 aboratory experiments have shown that the $\delta^{15_{N}}$ of decomposing organic matter undergoes large variations. The results of controlled decomposition experiments done by Wada (1980) are shown in Figure 3-35. One hundred and seventy-five to $500 \mathrm{mg}$ of phytoplankton (Chaetoceros), zooplankton (Calanus), and Trichodesmium, the $\mathrm{N}_{2}$-fixing alga, were left in 71 of filtered seawater inoculated with bacteria living in beach sand. The vessels, 10-1 polyethylene bottles, were aerated once a day by bubbling with oxygen for one hour. The $\delta^{15} \mathrm{~N}$ and concentration of PON were determined every 5 to 10 days for 31 days. Though the $\delta^{15} \mathrm{~N}$ of the starting POM was different among the three experiments, similar changes in $\delta^{15} \mathrm{~N}$ were observed. The trends were less pronounced in the Trichodesmium experiment because of the $10 \mathrm{w} \delta^{15} \mathrm{~N}$ of the starting organic matter and the high concentration of PON. Initially the $\delta^{15} \mathrm{~N}$ increased as PON concentrations decreased to low levels within 4 to 5 days. In the following period, the $\delta^{15} \mathrm{~N}$ decreased to values less than that of the original PON, concomitant with 10 to 30 percent increases in PON concentrations. The second phase of decomposition was interpreted by Wada (1980) to be the result of bacterial growth in which $15_{N}$-depleted bacterial biomass made up a significant fraction of the PON. Further isotope changes occurred as the bacteria continued to mineralize the PON. Though this interpretation may be partially correct, bacterial biomass was not measured and thus it is difficult to determine at what point(s) bacterial synthesis of PON was occurring. An alternative interpretation of the data was suggested above, viz. that bacteria are sequentially breaking bonds having different relative abundances of ${ }^{15} \mathrm{~N}$. For example, the initial increase in $\delta^{15} \mathrm{~N}$ represents the loss of the most labile nitrogen which

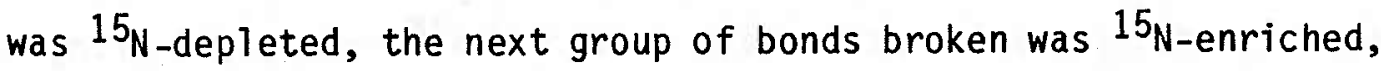
and the next ${ }^{15} \mathrm{~N}$-depleted, and so on. It is evident that further studies of this process must focus on the isotope chemistry of specific organic compounds. 
Figure 3-35.

$\delta^{15} \mathrm{~N}$ of Decomposing POM versus Incubation Time (days)

a. Chaetoceros, sp.

b. Calanus plumchrus

c. Trichodesmium erthyraeum

from Wada (1980) 

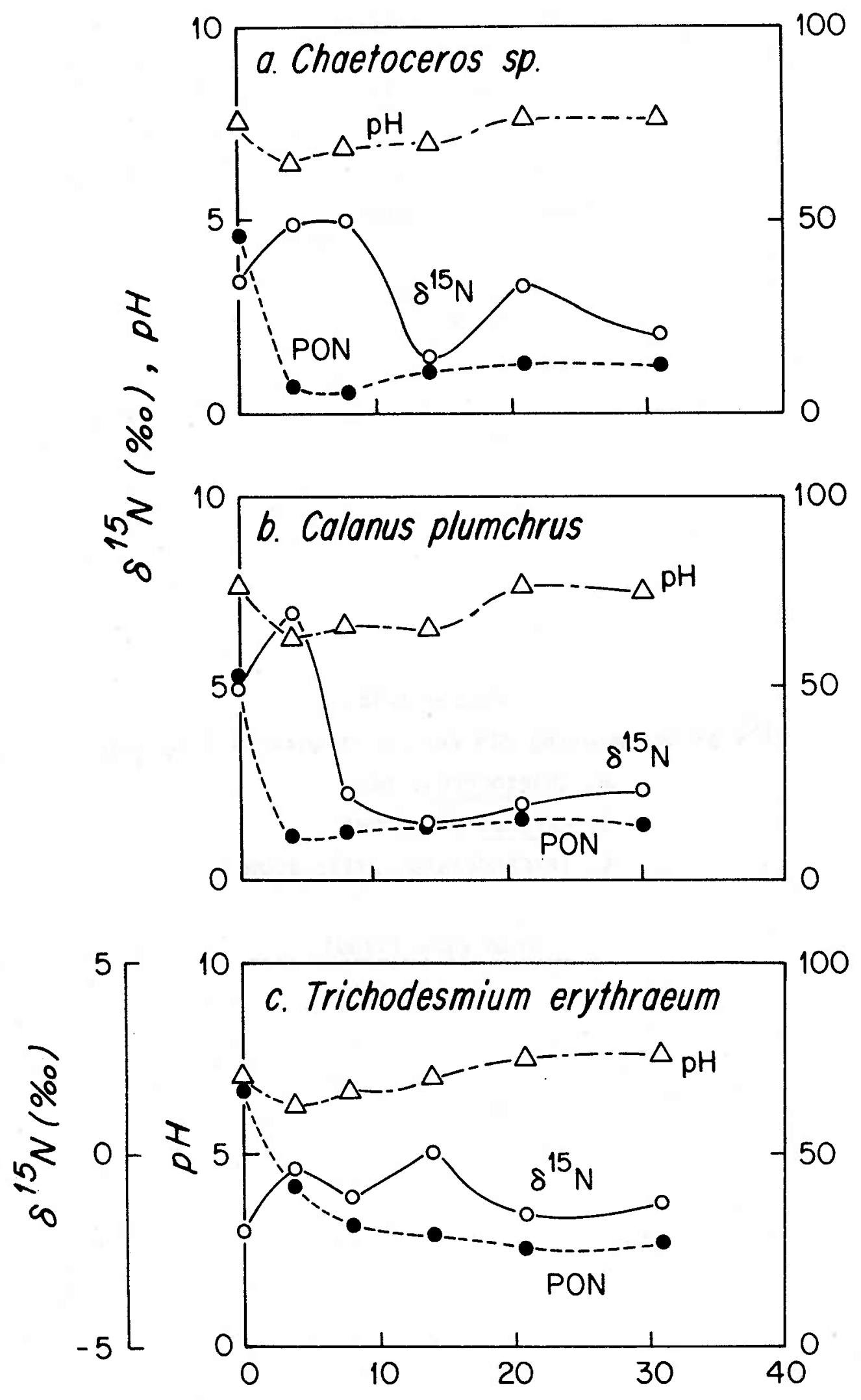
A process similar to that observed by Wada (1980) appeared to be occurring at Station $A$, where small increases in $P O C$ and $P O N$ concentration occurred at 35 and $40 \mathrm{~m}$, respectively. The $10 \mathrm{w} C / \mathrm{N}$ ratios and $\delta^{15} \mathrm{~N}$ of these particles suggested that bacterial synthesis of organic matter contributed significantly to the POM at these depths. As mentioned earlier, Macko (1982b) has observed bacterial biomass (Anabaena) to be 11 to $13^{\circ} \% 0$ lighter than its substrate. Bacterial numbers are sufficiently high in the Peru Upwelling Area (equivalent to 5 to $120 \mu \mathrm{g} C / 1$ ) (Sorokin and Kogel schatz, 1979) to generate this kind of effect.

Bacterial growth is expected to be most important in determining the $\delta^{15} \mathrm{~N}$ of POM when PON concentrations are low. Thus it is not suggested that anaerobic bacterial activity proceeds with greater isotopic fractionation than that achieved by aerobic bacteria, but that the low PON concentrations characteristic of the suboxic zone make possible the measureable impact of bacteria on the $\delta^{15} \mathrm{~N}$ of the PON. In addition, the absence of other biological activity in the suboxic waters makes the bacterial signal clearer.

In summary, it appears that the $\delta^{15} \mathrm{~N}$ of POM reflects biological activity in the water column. In the surface waters, POM tended isotopically to resemble the plankton, being enriched in $15_{\mathrm{N}}$. This was

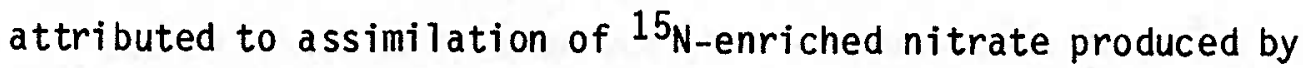
denitrification and brought to the sea-surface by upwelling. The $\delta^{15} \mathrm{~N}$ of particles collected from the oxygen-depleted waters tended to decrease with increasing depth, suggesting the cumulative effects of isotopic alteration during microbial mineralization and biomass synthesis. Further isotopic alteration may have occurred at the sediment/water interface. This process is discussed in the next section. 
Sediments

General Description:

The composition of the surface sediments in the Peru Upwelling Area is extremely variable. The presence of diatoms and fish debris is common as are carbonate oozes and phosphorite deposits (Henrichs, 1980; Suess, 1982). Organic-carbon content is also very variable, ranging from $<1$ percent to maximum values of 20 percent in the mud lens found from $11^{\circ}$ to $14^{\circ} \mathrm{S}$ along the shelf break (Figure $3-36$ ). Thick mats of Thioploca, a filamentous bacterium, have been frequently observed in the organic-rich sediments. The distinctive accumulation of organic matter is the result of the 1 arge POM flux to the sediments, as well as of the effects of $10 \mathrm{w}$ oxygen concentrations in the bottom waters along the shelf break (Re imers, 1981).

The sediments analyzed in this study were collected with a $7-\mathrm{cm}$ diameter gravity corer. The large diameter and shallow-water depths made sampling and recovery of relatively undisturbed cores possible. Each core was sectioned into depth intervals to provide detailed profiles of $\delta^{15} \mathrm{~N}, \delta^{13} \mathrm{C}$, percent organic nitrogen and carbon, and $\mathrm{C} / \mathrm{N}$ ratios. Replicate analyses demonstrated reproducibilities of $\pm 0.1 \%$ for the isotope analyses, \pm 0.01 for percent organic nitrogen, \pm 0.1 for percent organic carbon and \pm 0.1 for $C / N$ ratios. In comparison to the large variation in $\delta^{15} \mathrm{~N}$ and $\delta^{13} \mathrm{C}$ found in POM, sedimentary isotopic values were relatively constant within cores and between all the stations.

\section{Results of Isotopic Analyses of Sediment:}

\section{Station SEAREX:}

The $\delta^{15_{N}}$ and $\delta^{13} \mathrm{C}$ of the sediments at Station SEAREX are shown in (Figure 3-37). The low nitrogen and carbon contents (Figure 3-38) are characteristic of sediments 1 ocated outside the organic-rich mud lens. The results from Station SEAREX are unique in that, except for $\mathrm{C} / \mathrm{N}$ ratio, all of the sedimentary profiles covary. The $\delta^{15_{N}}$ and $\delta^{13} \mathrm{C}$ profiles 
$-190-$

Figure 3-36.

The Distribution of Percent Organic Carbon in the Sediments off the Coast of Peru, from Reimers (1981) 


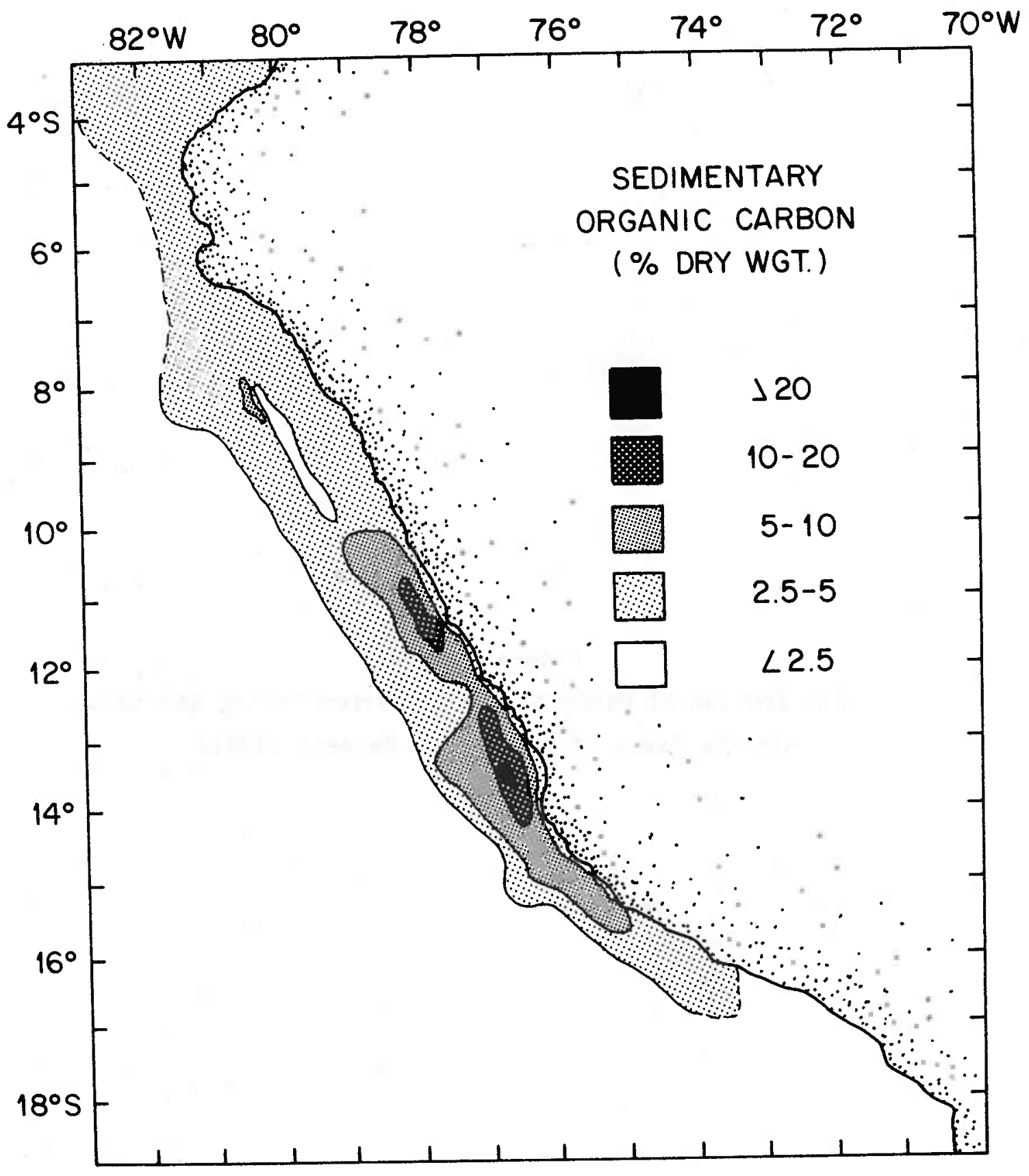


$-192-$

Figure 3-37.

Peru Upwelling Area

Station SEAREX: $\delta^{15} \mathrm{~N}$ and $\delta^{13} \mathrm{C}$ of the Sediments 


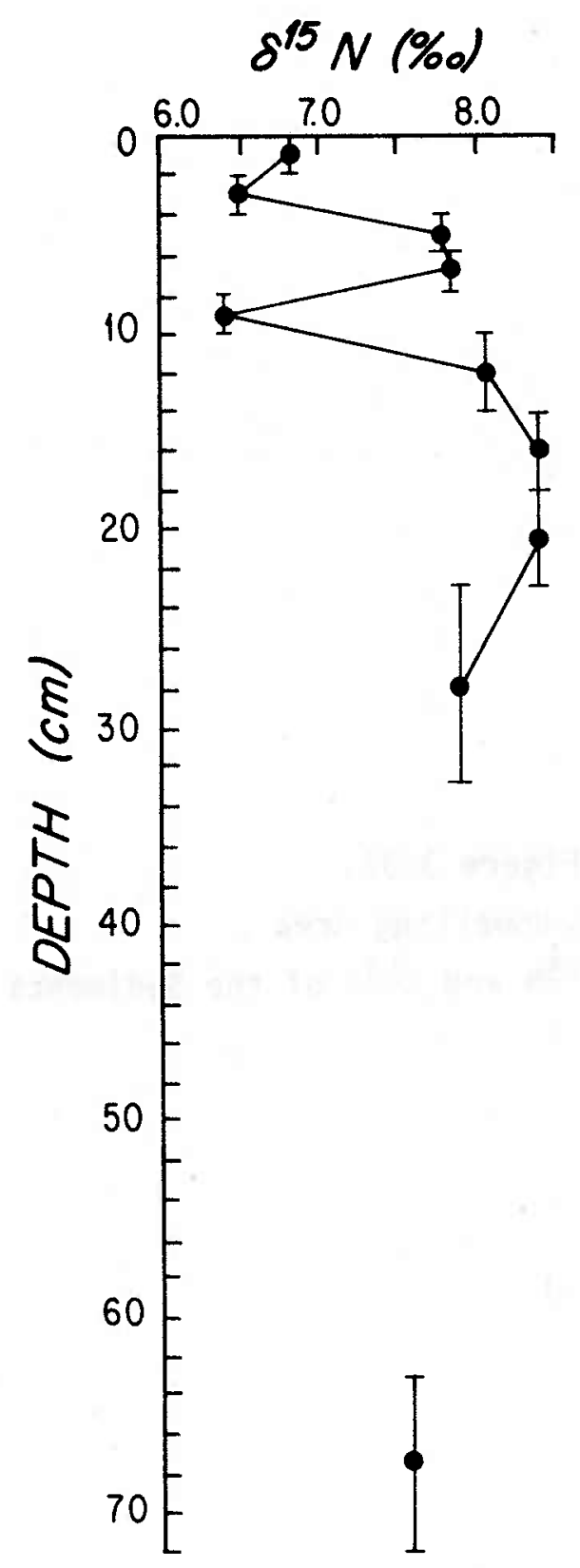

$\delta^{13} \mathrm{C}(\%)$
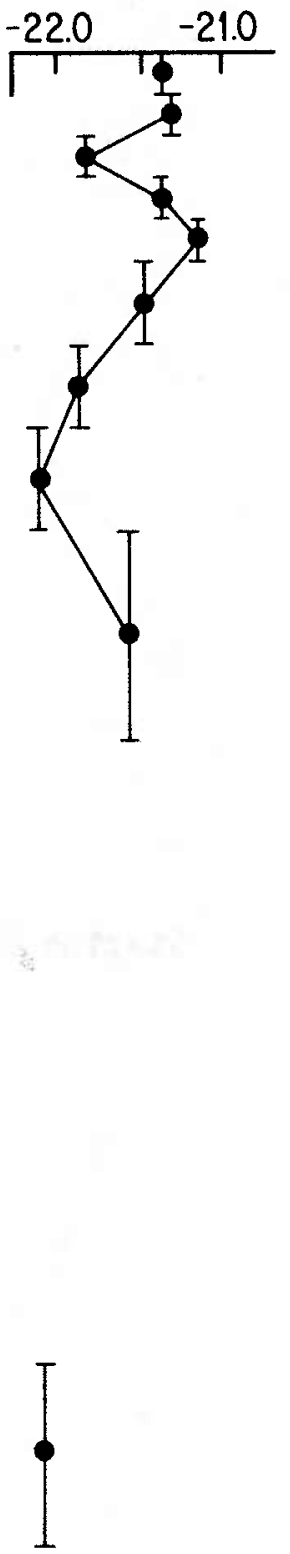

Station SEAREX 
Figure 3-38.

Peru Upwelling Area

Station SEAREX: Percent Organic Nitrogen and Carbon, and $\mathrm{C} / \mathrm{N}$ Ratio in the Sediments 


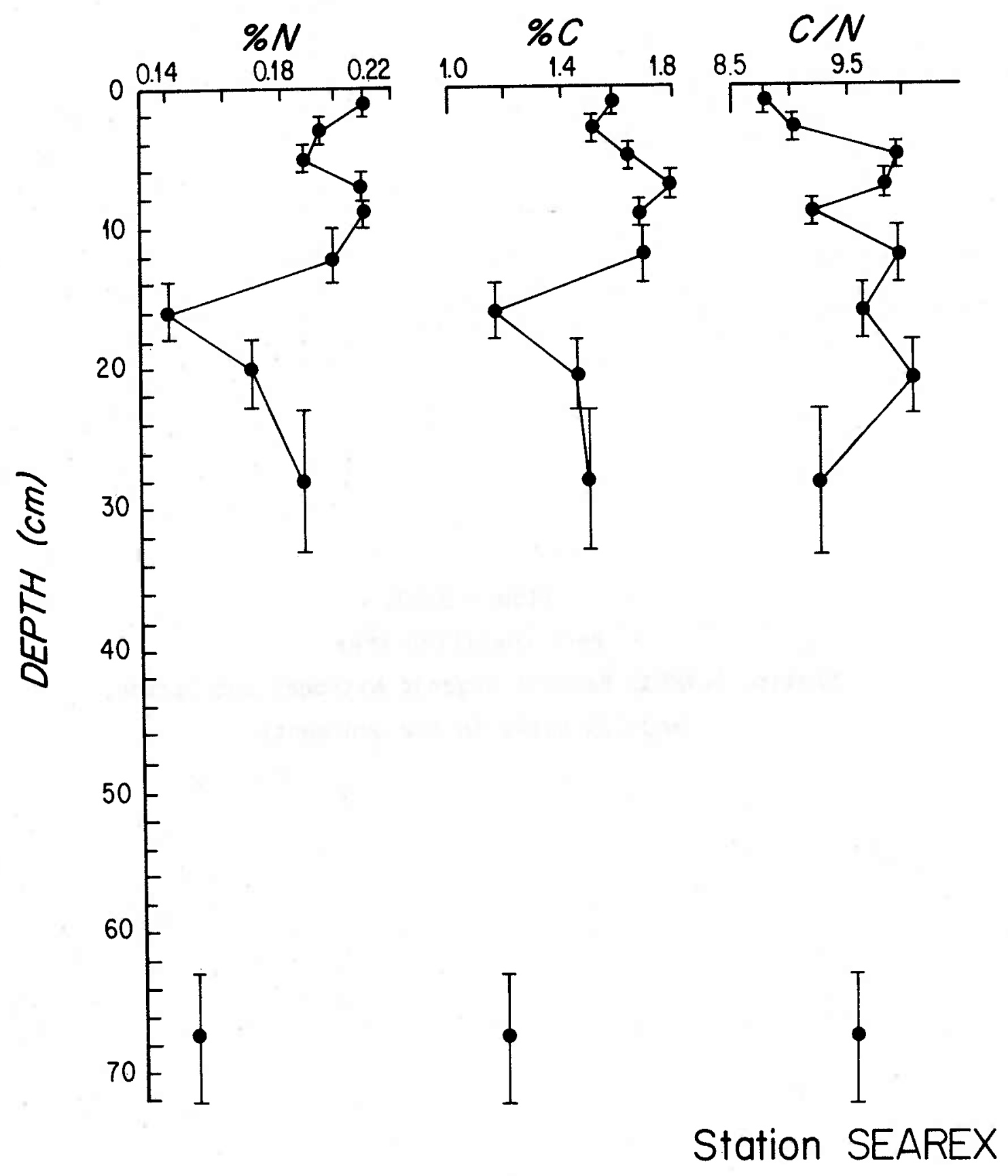


are almost mirror images and the percent carbon and nitrogen profiles are directly covariant. The sediment was brown, no $\mathrm{H}_{2} \mathrm{~S}$ was detected, and some worms were visible at the surface, suggesting oxidizing conditions.

Station SEAREX was the most inshore station sampled and had the lowest $\delta^{13} \mathrm{C}$ of the sediments sampled, suggesting the presence of terrestrial organic matter. The fluctuations in the sedimentary profiles may thus reflect varying inputs of terrestrial organic material, which may be related to $E 1$ Niño events, during which warm, saline waters intrude into the Peru Upwelling Region. The lack of upwelling during $E 1$ Niño events prevents the usual high biological productivity, causing economic disaster for the Peruvian fishing industry. Torrential rainfalls are associated with these periodic events and, though the Peruvian coast west of the Andes is arid, increased run-off should carry more terrestial debris offshore. Particularly severe El Ninos occurred during 1966, 1972-1973, and 1976 usually lasting for several months (Quinn et al., 1978).

The percent $C$, percent $N, \delta^{13} \mathrm{C}$ and $\delta^{15_{N}}$ profiles may be useful in identifying the sedimentary layers deposited during these events. Pronounced minima in percent organic nitrogen and carbon occurred at 14-18 cm and much lesser ones were centered in the top $6 \mathrm{~cm}$ (Figure 3-38). These minima may be associated with El Niño events if the particle flux during these events is composed of an abnormally large amount of terrestrial debris having a low organic matter content. ${ }_{\delta}^{13} \mathrm{C}$ minima are present at $4-6 \mathrm{~cm}$ and $14-23 \mathrm{~cm}$, suggesting increased amounts of terrestrial debris at these depths. These minima are coincident with $\delta^{15} \mathrm{~N}$ maxima at 4-8 cm and $14-23 \mathrm{~cm}$. The maxima and minima of the different properties are not exactly coincident, perhaps due to the large intervals sampled and the effects of bioturbation in this oxic core. Al though the correlation of these sedimentary profiles with El Niño events is tenuous, the data suggest that $\delta^{13} \mathrm{C}$ and $\delta^{15 \mathrm{~N}}$ may be usefur in tracing sources of organic matter to nearshore sediments. 


\section{Station A:}

The sediments at Station A had slightly higher organic-nitrogen and organic-carbon contents (Figure $3-40$ ), but $C / N$ ratios similar to those at Station SEAREX. The range in $\delta 15 \mathrm{~N}$ was similar to that at Station SEAREX, but the ${ }^{13} \mathrm{C}$ values were much higher (Figure $3-39$ ), suggesting a smaller input of terrestrial organic matter at Station $A$. Minima in percent organic nitrogen and carbon at $0-2,8-10$, and $16-28 \mathrm{~cm}$ were coincident with distinct black 1 ayers. At $16-18 \mathrm{~cm}, \delta^{13} \mathrm{C}$ and $\delta{ }^{15} \mathrm{~N}$ minima were also present, suggesting some change in the depositional history.

Station B and Two other Shelf-Break Stations:

The results of analyses of the $0-2 \mathrm{~cm}$ interval from two stations located on the shelf break at $15^{\circ} \mathrm{S}$, and occupied during the SEAREX cruise, are shown along with the results from Stations $A, B$, and $C$ in Table 3-2. Core 8 was anoxic, dark-brown in color and fecal pellets were identifiable at the sediment surface. Yellow-brown layers were present at several intervals (2-4, 7-9 and 11-12 cm). Core 3 was oxic at the surface and al so had distinct yellow-brown layers at 0-2, 5-7 and 10-12 cm. Below $12 \mathrm{~cm}$, the sediment of Core 3 was anoxic.

The organic-matter contents of the Cores 3 and 8 were intermediate between those of the inshore stations and Station $B$. Despite differences in organic-matter percentages, the isotope and $C / N$ ratios of the $0-2 \mathrm{~cm}$ interval of cores 8 and 3 were remarkably similar, suggesting some uniformity in the $\delta^{13} \mathrm{C}$ and $\delta^{15}$ of the source of organic matter to the sediments or in benthic activity.

The sediments collected at Station B (Figure 3-41) were notable both for the very high nitrogen and carbon contents and the presence of long strands of Thioploca through the top $10 \mathrm{~cm}$. The strands were mostly oriented vertically and were not found below $10 \mathrm{~cm}$ where the sediment was finer-grained. 
$-198$

Figure 3-39.

Peru Upwelling Area

Station $A: \delta^{15} \mathrm{~N}$ and $\delta^{13} \mathrm{C}$ of the Sediments 


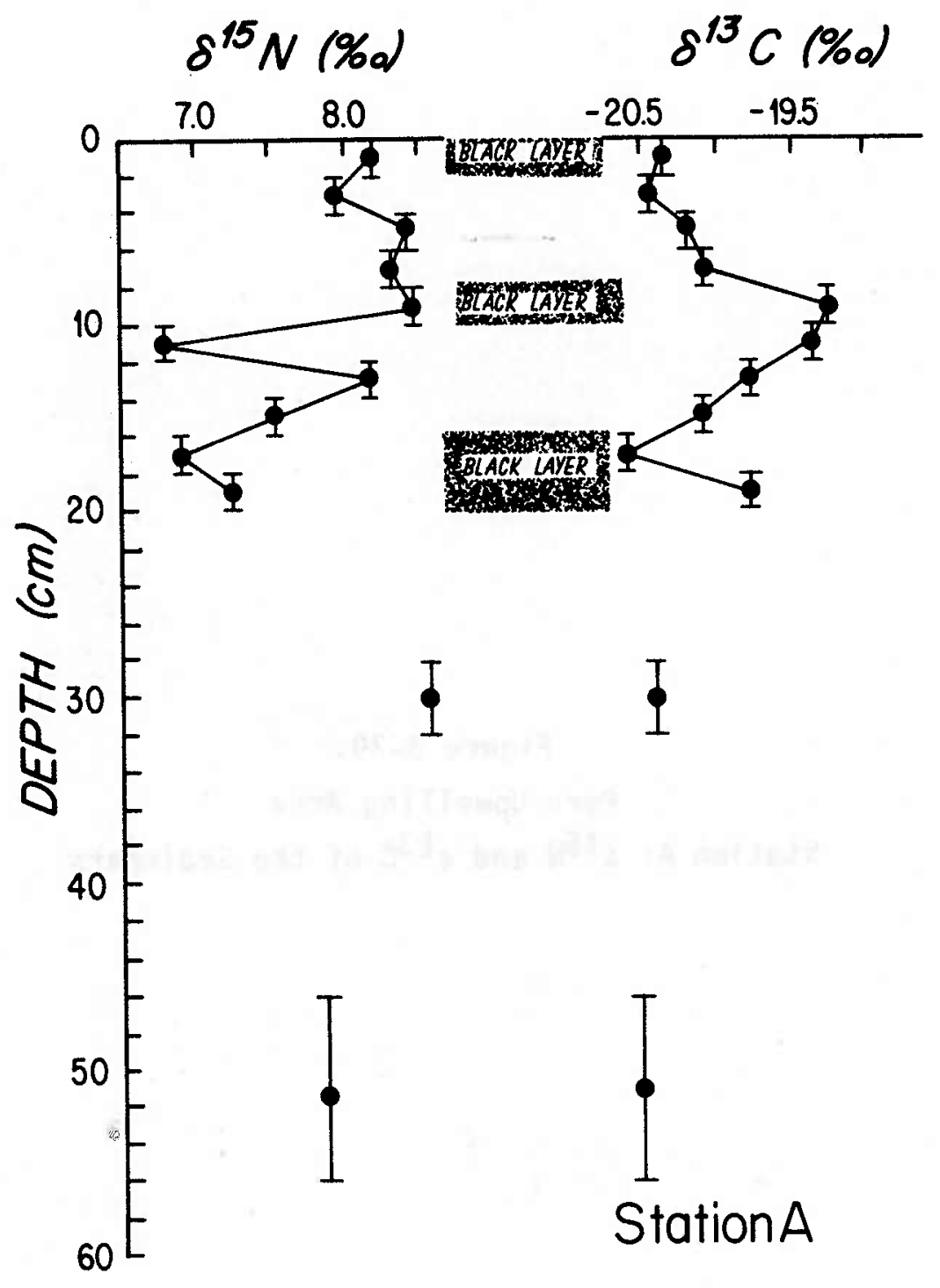


Figure 3-40.

Peru Upwelling Area

Station A: Percent Organic Nitrogen and Carbon, and $C / N$ Ratio in the Sediments 


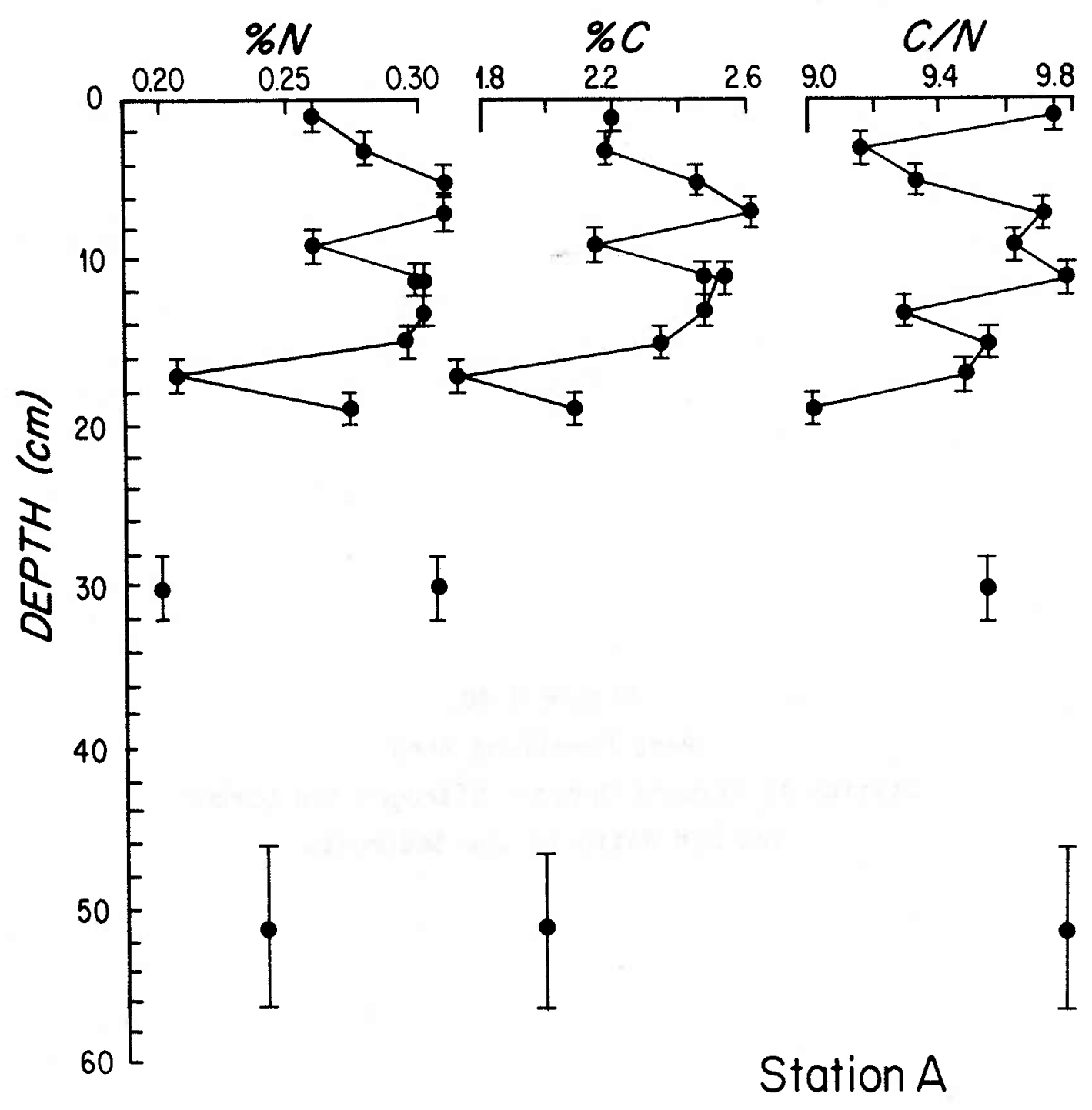


Table 3-2.

Surface Sediments $(0-2 \mathrm{~cm})$ from the Peru Upwelling Area:

Percent Organic Nitrogen and Carbon, C/N Ratio, $\delta^{15_{N}}$, and $\delta^{13} \mathrm{C}$

$\begin{array}{lllllll}\text { Station } & \text { Water } & \delta^{15} \mathrm{~N} & \delta^{13} \mathrm{C} & \mathrm{C} / \mathrm{N} & \text { Percent } & \text { Percent } \\ & \operatorname{Depth}(\mathrm{m}) & (\% / 00) & \left({ }^{0} / 00\right) & & \text { Org. } \mathrm{N} & \text { Org. C }\end{array}$

\begin{tabular}{lrrrrrr}
\hline SEAREX & 80 & 6.8 & -21.4 & 8.8 & 0.21 & 1.6 \\
A & 48 & 8.2 & -20.4 & 9.8 & 0.26 & 2.2 \\
$3^{*}$ & 160 & 8.0 & -20.2 & 9.3 & 0.60 & 4.8 \\
$8^{* *}$ & 210 & 7.8 & -19.9 & 9.4 & 0.75 & 6.1 \\
B & 320 & 6.1 & -26.8 & 10.0 & 1.07 & 9.2 \\
C & 4580 & 9.0 & -20.0 & 5.2 & 0.11 & 0.5 \\
\hline
\end{tabular}

* Located at: $15^{\circ} 05.2^{\prime} \mathrm{S} \quad 75^{\circ} 37.0^{\prime} \mathrm{W}$
$\star \star$ Located at: $15^{\circ} 04.5^{\prime} \mathrm{S} \quad 75^{\circ} 41.4^{\prime} \mathrm{W}$ 
Figure 3-41.

Peru Upwelling Area

Station $\mathrm{B}: \delta^{15} \mathrm{~N}, \delta^{13} \mathrm{C}$, Percent Organic Nitrogen and Carbon, and $C / N$ Ratio in the Sediments 


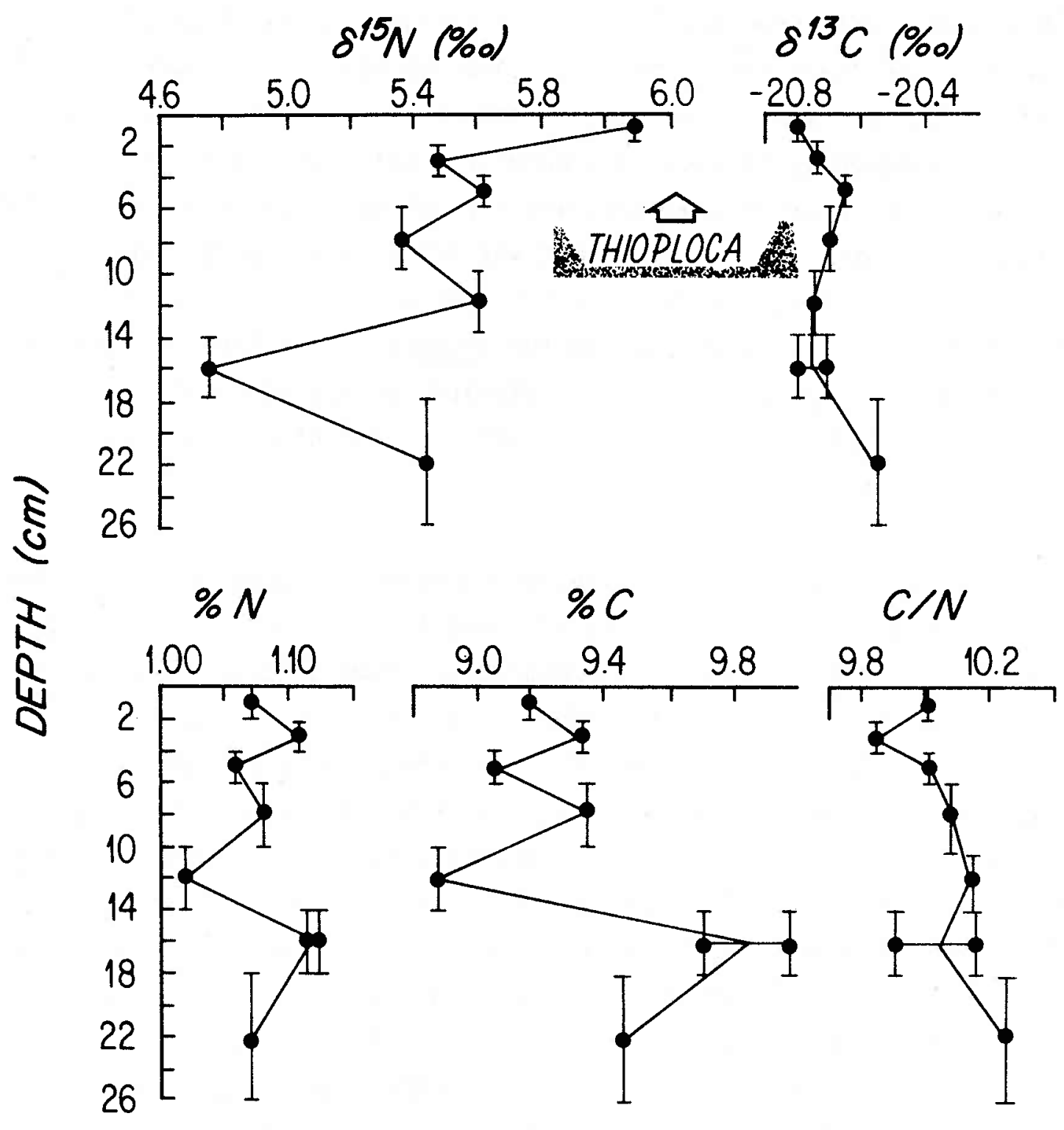

Station B 
Though the ${ }^{13} \mathrm{C}$ values were constant throughout the $26-\mathrm{cin}$ core, the ${ }_{\delta}^{15} \mathrm{~N}$ values ranged from $+6.0 \%$ at the surface, to $+4.8^{\circ} / 00$ at $14-18 \mathrm{~cm}$. The sharp $\delta^{15} \mathrm{~N}$ minimum at $14-18 \mathrm{~cm}$ was coincident with the highest organic-nitrogen and carbon contents in the core. Though the smell of hydrogen sulfide was not detected, the high organic-matter content, black color of the core, and lack of macro-organisms other than Thioploca, suggest that the sediment was anoxic and that perhaps methanogenesis was occurring. The nitrogen and carbon maxima and $\delta^{15_{N}}$ minimum at $14-18 \mathrm{~cm}$, located below the Thioploca, may have been related to some bacterial process, or as at Stations SEAREX and Station A, it may have been related to changes in the isotopic content of the POM accumulating in the sediments.

Below $2 \mathrm{~cm}$, the $\delta^{15} \mathrm{~N}$ of the sediments were unusually low, being the lowest of all the sediments analyzed $(+4.8$ to $+5.6 \%$ in this study of the Peru Upwelling Area. In comparison, Reimers (1981) found $\delta^{15} \mathrm{~N}$ values of +0.5 to $+6.0^{\circ} / 00$ in sediments from the same area. She suggested that in-situ $\mathrm{N}_{2}$ fixation caused this ${ }^{15} \mathrm{~N}$ depletion, though evidence for significant sedimentary $\mathrm{N}_{2}$ fixation is 1 imited to shallow coastal areas where organic-matter concentrations are high and photosynthetic $\mathrm{N}_{2}$-fixing bacteria are active (Capone and Carpenter, 1982). Furthermore, the high $\mathrm{C} / \mathrm{N}$ ratios $(9.8$ to 10.2$)$ in the sediments from Station $B$ were comparable to those found at other stations, arguing against significant amounts of $\mathrm{N}_{2}$ fixation. Alternatively, autotrophic fixation of carbon may have contributed to the high carbon concentrations and $C / N$ ratios. Beggiatoa, spp., filamentous bacteria similar to Thioploca, appear to grow chemosynthetically using hydrogen sulfide as an energy source (Jorgensen, 1977). It is suggested that Thioploca or some other benthic micro-organism having a similar metabolism, may have contributed to both the high organic-matter concentrations and the low $\delta^{15} \mathrm{~N}$ of the sediments as bacterial biomass appears to be depleted in $15 \mathrm{~N}$. 
Station C:

The low nitrogen and carbon contents of the sediments at Station $C$ reflect the efficient mineralization of POM in the long water column along with the lower productivity at this most offshore station. No hydrogen sulfide was detected and the uniformly low organic-matter content throughout the core suggest that oxidizing conditions prevailed.

Since the sedimentation rate was probably much lower than at the inshore stations (Reimers, 1981), the sediments sampled at Station C may represent a much longer time span of accumulation. If so, the down-core profiles should show the largest effects of diagenesis and bioturbation. In contrast to the variable profiles of the more inshore stations, all of the profiles at Station C (Figure 3-42) have persistent trends through many centimeters of sediment, suggesting the effects of these processes. Interestingly, the 1 argest range in sedimentary $\delta^{15} \mathrm{~N}$ was found at this station.

The $C / N$ ratios were relatively 10 w and constant except for transitions at $11 \mathrm{~cm}$ and $26 \mathrm{~cm}$. The subtle changes from 5.1 to 5.9 and 5.9 to 7.0 , respectively, suggest the effects of diagenesis and bioturbation rather than small long-term changes in the $\mathrm{C} / \mathrm{N}$ ratio of the POM accumulating in the sediments. If mineralization of organic matter was occurring, it was insufficient to erase the trend of higher organic content in the POM accumulating when the older sediments were deposited. Thus the trends in $\delta^{13} \mathrm{C}$ and $15 \mathrm{~N}$, if diagenetic in nature, must have been produced by very significant isotopic alteration of a small part of the bulk sedimentary organic carbon and nitrogen. The jump in the $\delta 15 \mathrm{~N}$, percent $\mathrm{N}$, percent $\mathrm{C}$, and $\mathrm{C} / \mathrm{N}$ profiles coincident with the presence of a red-brown layer at 26-36 cm suggests an abrupt change in the conditions that 1 ed to the deposition of this sediment.

Discussion of Sediment Results:

In comparison to the wide range in the $\delta 15 \mathrm{~N}(-2$ to $+17 \% / 00)$ and ${ }^{13} \mathrm{C}(-16$ to $-360 \%)$ of POM, the ranges in the sediments were 
$-207-$

Figure 3-42.

Peru Upwelling Area

Station C: $\delta^{15} \mathrm{~N}, \delta^{13} \mathrm{C}$, Percent Organic Nitrogen and Carbon, and $\mathrm{C} / \mathrm{N}$ Ratio in the Sediments 


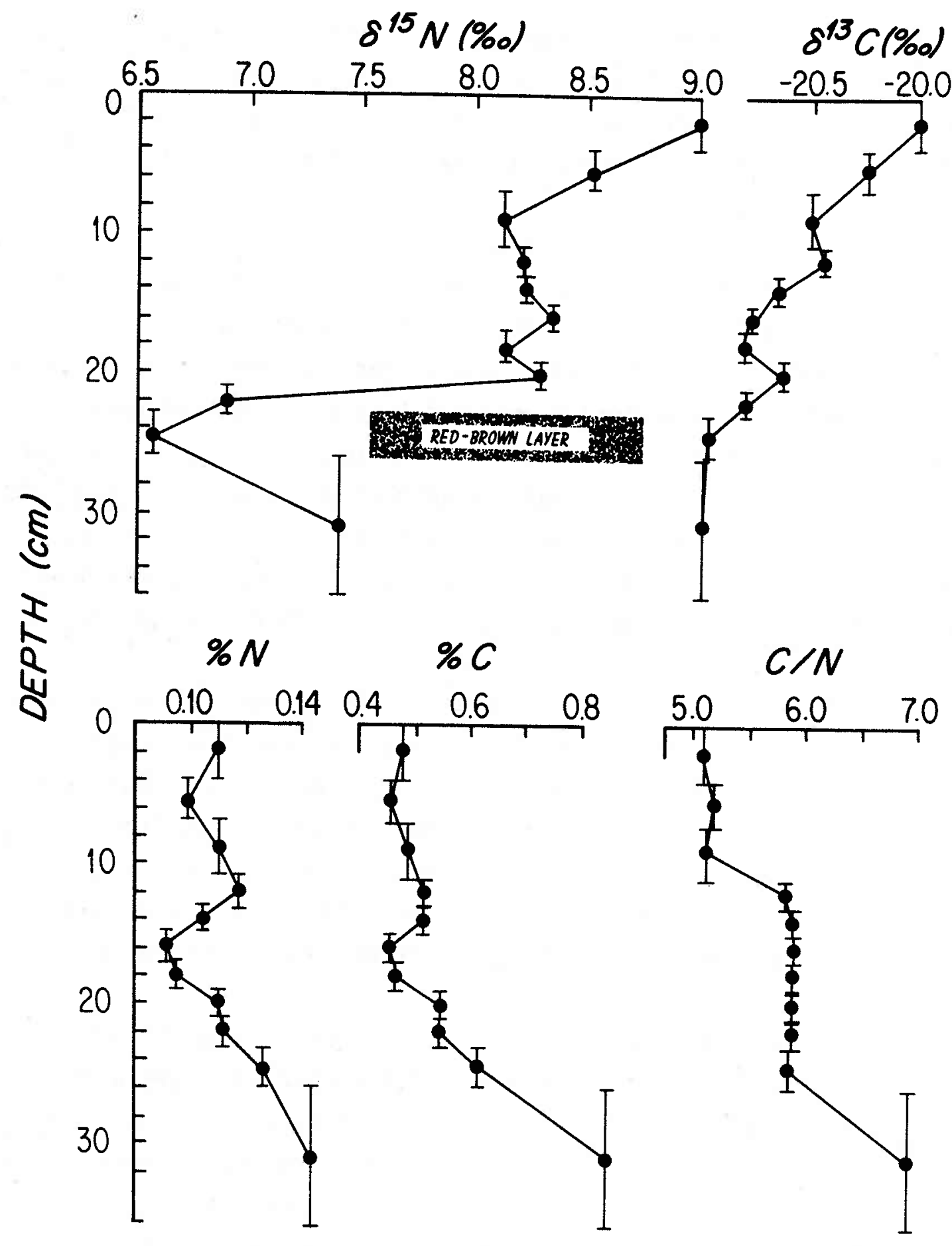

Station C 
relatively small $\left(+6\right.$ to $+90 / 00$ and -20 to $\left.-22^{0} / 00\right)$. This may be due to the fact that the sediments reflect an average $\delta^{15} \mathrm{~N}$ of accumulating POM, which may on short time scales be isotopically variable. Alternatively, benthic activity may have caused the uniformity in the sedimentary label.

The presence of a large benthic biomass in the Peru Upwelling Area has already been noted. In addition to the work of Rowe (1971), Reimers (1981) and Henrichs (1980) have also observed that the effect of benthic activity is not as pronounced in the mud lens as in its landward and seaward edges (Figure 3-36). The anoxic sediments in the mud lens may be subject to less bioturbation, but the ubiquitous presence of Thioploca suggests that bacterial activity is significant in these sediments. Thus the difference in the type of benthic activity at Station B may have been caused the anomalously $10 \mathrm{w} \delta^{15} \mathrm{~N}$ of the sediments from this station.

Reimers (1981) has shown that considerable mineralization of organic matter occurs at the sediment/water interface in the Peru Upwelling Area. The effect of this process can also be seen in Table 3-3, which shows significant differences between the "percent POC and PON" of the bottom-water particles and the percent organic carbon and nitrogen in the underlying surface sediments. Significant differences in $\mathrm{C} / \mathrm{N}$ ratios are also evidence for the transformation of organic matter at the interface.

If diagenesis was causing a significant loss of organic matter, profiles of organic carbon and nitrogen contents should show decreases with increasing depth and $C / N$ ratios should increase with increasing depth (Reimers, 1981). Since none of the sedimentary profiles exhibited such trends, it is concluded that diagenesis in these short cores was insufficient to erase the percent carbon, $n i$ trogen and $C / N$ ratio signatures generated by the POM flux and transformations at the sediment/water interface.

Further evidence for the importance of the POM flux and transformation 
Table 3-3.

Deepest POM and Surface Sediments $(0-2 \mathrm{~cm})$

from the Peru Upwelling Area

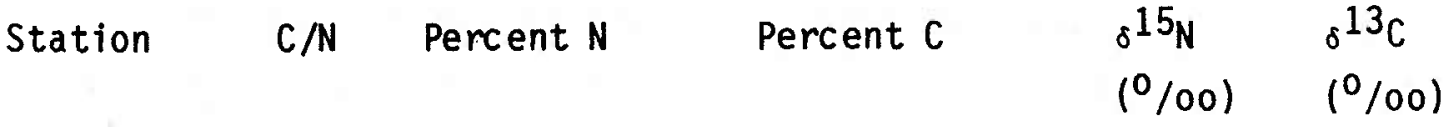

SEAREX

$\begin{array}{crrrrr}\text { POM } & 11.4 & .84 & 8.2 & +6.9 & -19.1 \\ \text { Surf. Sed. } & 8.8 & 0.21 & 1.6 & +6.8 & -21.4\end{array}$

$\underline{A}$

$\begin{array}{clllll}\text { POM } & 4.2 & 2.7 & 9.4 & +3.8 & -20.1 \\ \text { Surf. Sed. } & 9.8 & 0.26 & 2.2 & +8.2 & -20.4\end{array}$

$\underline{B}$

$\begin{array}{lrllll}\text { POM } & 8.6 & 3.2 & 23.8 & +2.5 & -20.8 \\ \text { Surf.Sed. } 10.0 & 1.07 & 10.0 & +6.1 & -20.8\end{array}$

$\underline{C}$

$\begin{array}{lcccc}\text { POM } 12.1 & .- & .- & +9.1 & -24.8 \\ \text { Surf.Sed. } 5.2 & 0.11 & 0.5 & +9.0 & -20.0\end{array}$


at the sediment/water interface in determining the chemical composition of the sediments is seen in Figures $3-43$ and $3-44$. When the $\delta^{15} \mathrm{~N}$ values of all the sediment samples are plotted versus percent organic nitrogen or $\mathrm{C} / \mathrm{N}$ ratio, each station's data fall into discrete areas. This suggests that the sediments have obtained their chemical signatures either from the accumulating POM or from transformations at the sediment/water interface, and that the sediments retain these labels with little change from the $0-2 \mathrm{~cm}$ interval to $72 \mathrm{~cm}$, the deepest sediment analyzed. Alternatively, bioturbation may have homogenized the oxic cores, but this process can not be invoked to explain the homogeneity of the anoxic cores. It also requires that the effect of bioturbation has been relatively constant for long periods of time, since the deepest sediment analyzed $(72 \mathrm{~cm})$ had isotopic contents similar to the surface sediments.

It is difficult to assess whether bioturbation is the cause of the down-core variations, though the following observations suggest that the effects of bioturbation may produce down-core variations in $\delta^{15} \mathrm{~N}$. First, Reimers (1981) has shown that unconformities in the Peru Upwelling Area sediments result from changes in bottom circulation which may have caused changes in the benthic environment and thus in benthic activity. Secondly, lithological discontinuities may present barriers or hindrances to bioturbation. This may occur when current scouring removes enough of the overlying sediment to bring the lithological discontinuity back into the zone of bioturbation.

Since the nitrogen isotopic content of the POM is variable and the bottom-water particulates do not isotopically consistently resemble the surface sediments, alteration at the sediment/water interface appears to be important in producing the uniform sedimentary isotopic values. The station-to-station differences in isotopic content appear to reflect differences in specific benthic activities at each station, which in turn are dependent on the magnitude of the organic-matter flux to the sediments and on the oxygen concentration in the bottom waters. 
Figure 3-43.

$\delta^{15} \mathrm{~N}$ versus Percent Organic Nitrogen in Sediments of the Peru Upwelling Area 


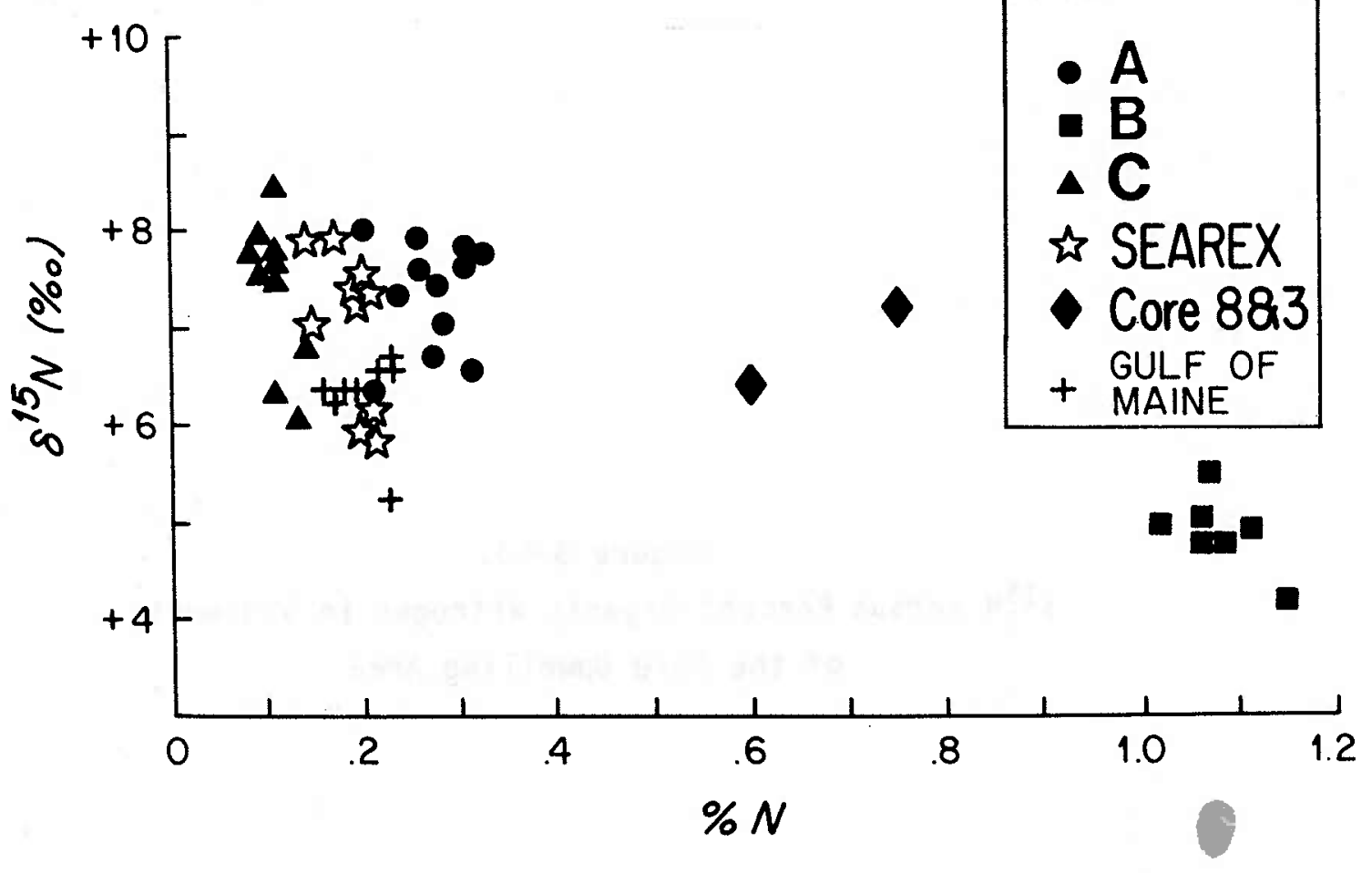


$-214-$

Figure 3-44.

$\delta^{15} \mathrm{~N}$ versus $\mathrm{C} / \mathrm{N}$ Ratio in Sediments

of the Peru Upwelling Area 


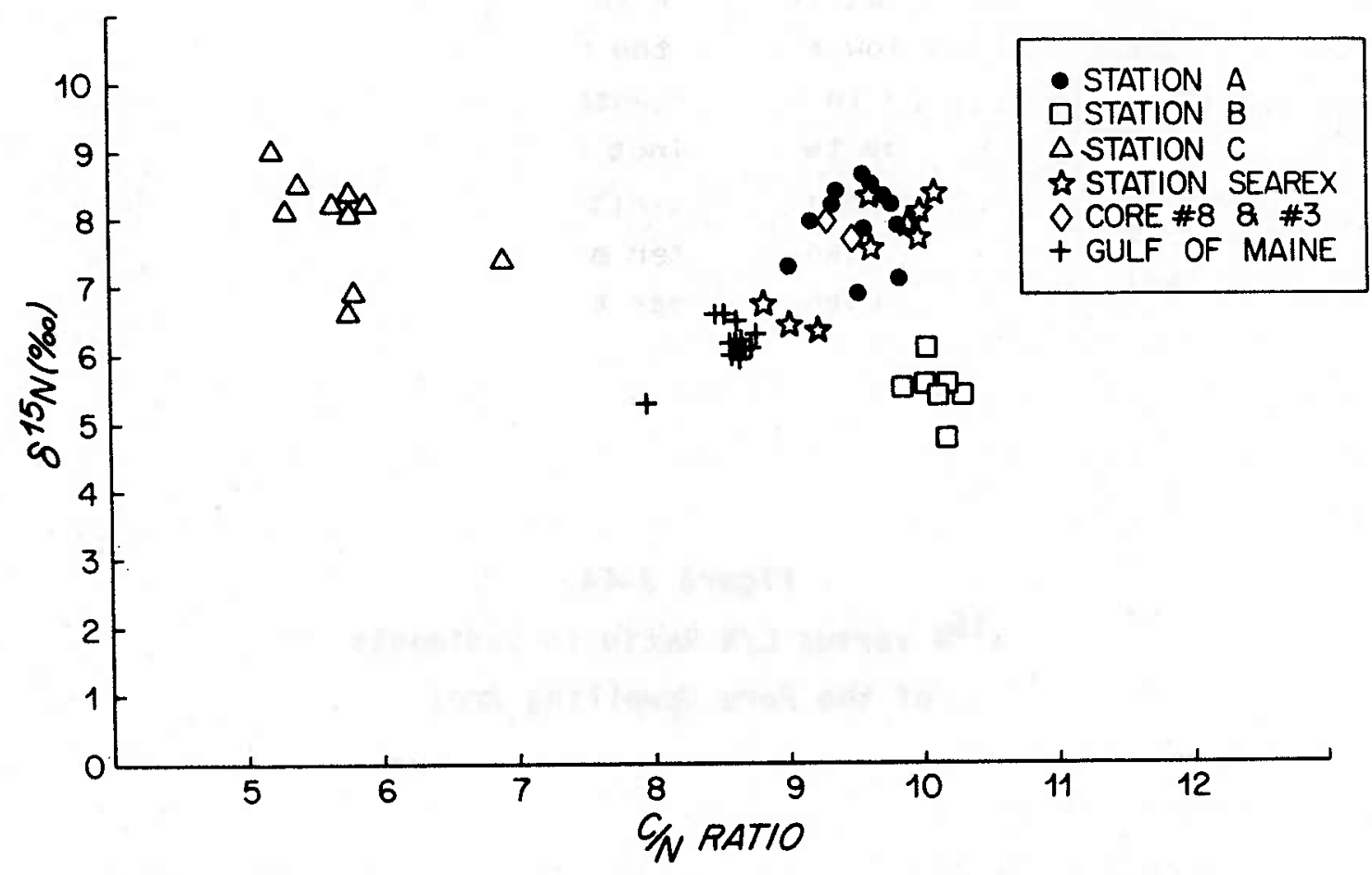


Any comparison between the POM and the sediments is complicated by several factors: 1) The sinking particles may not have been representatively sampled by the Niskin bottles. This effect was investigated in the Gulf of Maine by comparing POM collected with in-situ large-volume pumps to that collected by 30-1 Niskin bottles (see next chapter). 2) Horizontal transport may be an important source of particles. Reimers (1981) has determined that the distribution of sediments in the Peru Upwelling Area is dependent on the current regime, and on the large particle fluxes beneath the areas of intense upwelling.

From $5^{\circ}$ to $15^{\circ} \mathrm{S}$, a strong southerly current flows along the continental shelf with maximum velocities located between 40 and $70 \mathrm{~m}$ (Brockmann et al., 1980). At $12^{\circ} \mathrm{S}$ (Station A), deposition of organic matter is inhibited by current scouring and the usual presence of relatively elevated oxygen concentrations in the Peru Undercurrent waters. At $15^{\circ} \mathrm{S}$ (Station SEAREX) the flow becomes weak and variable causing deposition of particles brought south by this current. The particle load includes resuspended, reworked sediment, as well as fine-grained mineral detritus derived from terrestrial run-off. Most of the organic matter found in the sediments at $15^{\circ} \mathrm{S}$ is derived from local primary productivity as 1 arge, rapidly-settling fecal pellets comprise most of the POC flux to the sediment. Thus, though the carbon accumulation rates are very high at $15^{\circ} \mathrm{S}$, the organic-carbon content is anomalously low due to dilution by horizontally-advected inorganic detritus (Reimers, 1981).

Therefore, the sediments at Station SEAREX reflect the effects of terrestrial input more than at Station $A$ and the offshore stations. This is the likely cause of the $10 \mathrm{w} \delta^{13} \mathrm{C}$ of the sediments at Station SEAREX. Variability in the percentage of terrrestrial input to the sediment was suggested by two distinct ${ }^{13} \mathrm{C}$ minima, which correlated with $\delta{ }^{15} \mathrm{~N}$ maxima and organic-nitrogen and carbon concentration minima. The organic-matter minima may have been related to El Niño events, since these events appear to be associated with increased 
inputs of organic-poor terrestrial debris.

The current scouring at Station A makes similar interpretations of the depositional history of the sediments inappropriate. Reimers (1981) has shown that the sediments in the Peru Upwelling Area are characterized by unconformities related to changes in the current regime. The distinct isotope minima located at $16-18 \mathrm{~cm}$ in the Station A core may be evidence of such a change, especially since they occur at a lithologic discontinuity.

Sediments accumulating in water depths greater than $100 \mathrm{~m}$, as at Station $B$, are not presently subject to current scouring, permitting the deposition of 1 arge amounts of organic matter produced by upwelling along the shelf break. The presence of poorly oxygenated $(<0.1 \mathrm{ml} / 1)$ bottom waters also contributes to the accumulation of organic matter in a narrow band from 11 to $14^{\circ} \mathrm{S}$ along the shelf break. Though the sedimentary organic matter at Station $B$ is probably derived from local primary productivity, as previously described, Thioploca may contribute to the 1 ow $\delta 15 \mathrm{~N}$ of the sediments.

At Station $C$, low rates of primary productivity $\left(<0.1 \mathrm{~g} \mathrm{C} \mathrm{m}^{-2} \mathrm{~d}^{-1}\right.$, Zuta and Guillén, 1970) and the great length of the water column cause low sedimentation rates and low sedimentary organic-carbon and nitrogen contents. Thus the sediments represent a long time interval over which diagenesis may have significantly al tered the $i$ sotope content of the organic matter. In addition, bioturbation may have been important in redistributing the isotope content of the sediments. On the other hand, the increase in percent carbon and nitrogen with increasing depth in the sediments suggests that at least a partial record of changes in POM flux to the sediments and in transformations at the sediment/water interface has been retained by the sediments. The isotope profiles at Station $C$ are unique in comparison to those of the other stations, as the $\delta 15 \mathrm{~N}$ and $\delta 13 \mathrm{C}$ decreased with increasing depth in the core. These long-term trends are suggestive of 
the effects of significant post-depositional alteration. If diagenetic in nature, the trends in $\delta^{13} \mathrm{C}$ and $\delta^{15} \mathrm{~N}$ must have been produced by very significant isotopic alteration of a small part of the bulk sedimentary organic carbon and nitrogen. If not, long-term changes in the $\delta^{15_{\mathrm{N}}}$ and $\delta^{13} \mathrm{C}$ of the accumulating POM may have occurred.

Al ternatively, changes in benthic activity over time may have caused the trends. As suggested earlier, bioturbation may vary down-core and over time. 
CHAPTER IV

GULF OF MAINE

\section{Introduction}

The Gulf of Maine is a productive $10.8 \mathrm{~g} \mathrm{C} \mathrm{m}^{-2} \mathrm{~d}^{-1}, 0$ 'Reilly and Busch, 1982) area located off the coast of New England. It is composed of a series of deep basins, 100 to $300 \mathrm{~m}$ in depth, bounded by Georges Bank on the seaward side. The cyclonic surface and anticyclonic subsurface circulation in the Gulf has been described by Graham (1970). Seasonal changes in the general pattern of circulation cause changes in primary productivity. Winter mixing brings nutrients to the surface waters, triggering the spring bloom of phytoplankton. During the summer, nutrient concentrations decrease as POM produced by primary production sinks out of the euphotic zone. The increase in temperature of the surface waters causes stratification of the water column, preventing vertical transport of regenerated nutrients back into the euphotic zone. In addition to the seasonal cycle, shallow upwelling (Kangas and Hufford, 1974), tidal mixing, and storms often inject nutrients back into the surface waters causing periodic blooms of phytoplankton throughout the summer (Balch, 1981). By September, surface cooling begins to erode the sumer thermocline, producing an autumn phytoplankton bloom until temperatures drop to low levels. The seasonal cycle of nutrients and primary production in the Gulf of Maine has been reviewed by Balch (1981).

Diatoms and dinoflagellates are the dominant phytoplankton found in the Gulf of Maine with diatom-dinoflagellate communities dominating in the summer and dinoflagellate communities in the autumn. Chaetoceros, Thallassiothrix, Gonyaulax, and Rhizoselenia are some of the species commonly observed (Balch, 1981).

The biological cycling of nitrogen in the Gulf of Maine has been modeled by Schlitz and Cohen (1982). These workers found that the 
nitrogen demand of primary productivity was met by zooplankton excretion and microbial regeneration. They suggested that the bacteria were the major contributors to the nitrogen demand of the phytoplankton.

The TPM concentrations in the Gulf of Maine are characterized by high values in the top $25 \mathrm{~m}(100$ to $300 \mu \mathrm{g} / 1)$ and very high concentrations near the seafloor $(300$ to $1000 \mu \mathrm{g} / 1)$. The mid-waters have concentrations of less than $100 \mu \mathrm{g} / 1$. The bottom nepheloid layer appears to be a permanent feature throughout the Gulf of Maine, though the TPM concentrations were found to be variable (Spencer and Sachs, 1970; Spencer, 1975; Spencer, 1982). Because of the mineralogical similarity between the bottom-water particles and the sediments, Spencer and Sachs (1970) concluded that the nepheloid layer is composed of resuspended sediments.

The sediments in the Gulf of Maine are patchily distributed, with organic-rich ( $>1$ percent organic carbon) sediments being deposited in the deep basins. Sedimentation rates of 0.02 to $0.09 \mathrm{~cm} / \mathrm{yr}$ have been reported by Fass and Nittrouer (1976) and Henrichs (1980). The effects of bioturbation by macro- and meiofauna were reported by Henrichs (1980), while Lyons et a1., (1980) found chemical evidence for the occurrence of denitrification and sulfate reduction in the surface sediments from the Wilkinson basin. This attests to the heterogeneous geographic distribution of organic matter in the sediments.

\section{Station Location, Hydrography, and Nutrient Concentrations}

A single station (Figure 4-1) in the Wilkinson Basin (280 $\mathrm{m}$ water depth) was occupied during August of 1980. Plankton were collected with a 333- $\mu \mathrm{m}$ net by towing horizontally through the top $10 \mathrm{~m}$ of the water column. Water for nutrient and POM analyses was collected with 30-1 Niskin bottles as in the Peru Upwelling Area. In addition, POM was collected with in-situ large-volume pumps. Ninety to 450 liters of seawater were filtered over a period of 6.5 hours. Sediments were 
$-221-$

Figure 4-1.

Station Location in the Gulf of Maine (Indicated by the star) 


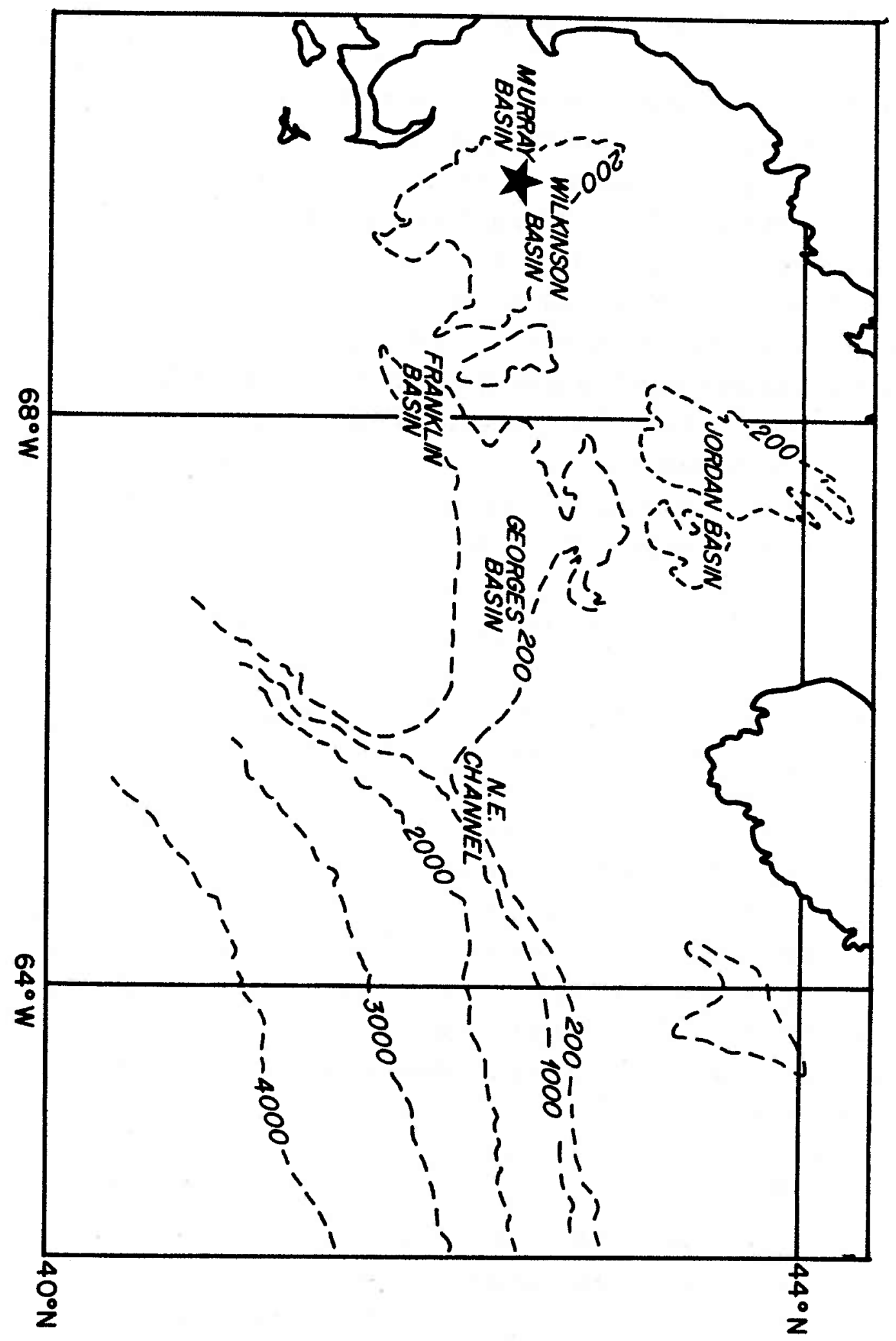


collected with a 7-cm diameter gravity corer.

The salinity, temperature, and density profiles are shown in Figure 4-2. The high surface-water temperature $\left(20^{\circ} \mathrm{C}\right)$ indicated that upwelling was not occurring during sampling. A well-mixed, low-salinity, warm layer was present from 0 to $20 \mathrm{~m}$ and a well-developed thermocline existed below $20 \mathrm{~m}$. The stratification of the upper water column prevented vertical transport of DIN to the surface waters. The absence of nitrate-plus-nitrite in these waters was due to removal by phytoplankton. 0xygen concentrations were high throughout the water column ( 5 to $7.5 \mathrm{ml} / 1$ ), though the decrease below $30 \mathrm{~m}$, coincident with increases in phosphate concentration and in silicate and nitrate concentrations below $50 \mathrm{~m}$, suggests that nutrient regeneration was occurring in the deeper waters (Figure 4-4).

Results and Discussion of Isotopic Analyses of Plankton

The plankton catch was composed primarily of Ceratium, a dinoflagellate, and copepods. In addition, small amounts of Chaetoceros, amphipods, mysids, euphausiids, and snail larvae were present. The $n i$ trogen and carbon contents, $C / N$ ratios, $\delta^{15} \mathrm{~N}$, and $\delta^{13} \mathrm{C}$ of the plankton are shown in Table 4-1. In contrast to the plankton from Peru, the size classes had similar $\delta^{15} \mathrm{~N}$ values. The $\delta^{15_{N}}$ of the Gulf of Maine plankton was identical to the average $\delta{ }^{15} \mathrm{~N}$ of plankton from the Northwest Pacific (Wada and Hattori, 1976; Wada, 1980) (see Figure 3-15) and was similar to the $\delta^{15 \mathrm{~N}}$ of nitrate $\left(+5\right.$ to $+7.5^{\circ} \% 0$, Figure $\left.1-4\right)$ from the NWP. Although this is a small sample of areas, it might indicate that the $\delta^{15} \mathrm{~N}$ of plankton is similar in areas where denitrification is unimportant or absent.

The ${ }^{13} \mathrm{C}\left(-19^{\circ} / 00\right)$ is typical of marine plankton. In contrast to the $\delta^{15_{N}}$, the $\delta^{13} \mathrm{C}$ of the plankton differed between size classes, being higher in the zooplankton $(>10 \mu \mathrm{m})$ than in the phytoplankton $(<10 \mu \mathrm{m})$ fraction. A similar trophic enrichment has been observed by 
$-224-$

Figure 4-2.

Gulf of Maine

Temperature, Salinity, and Density 


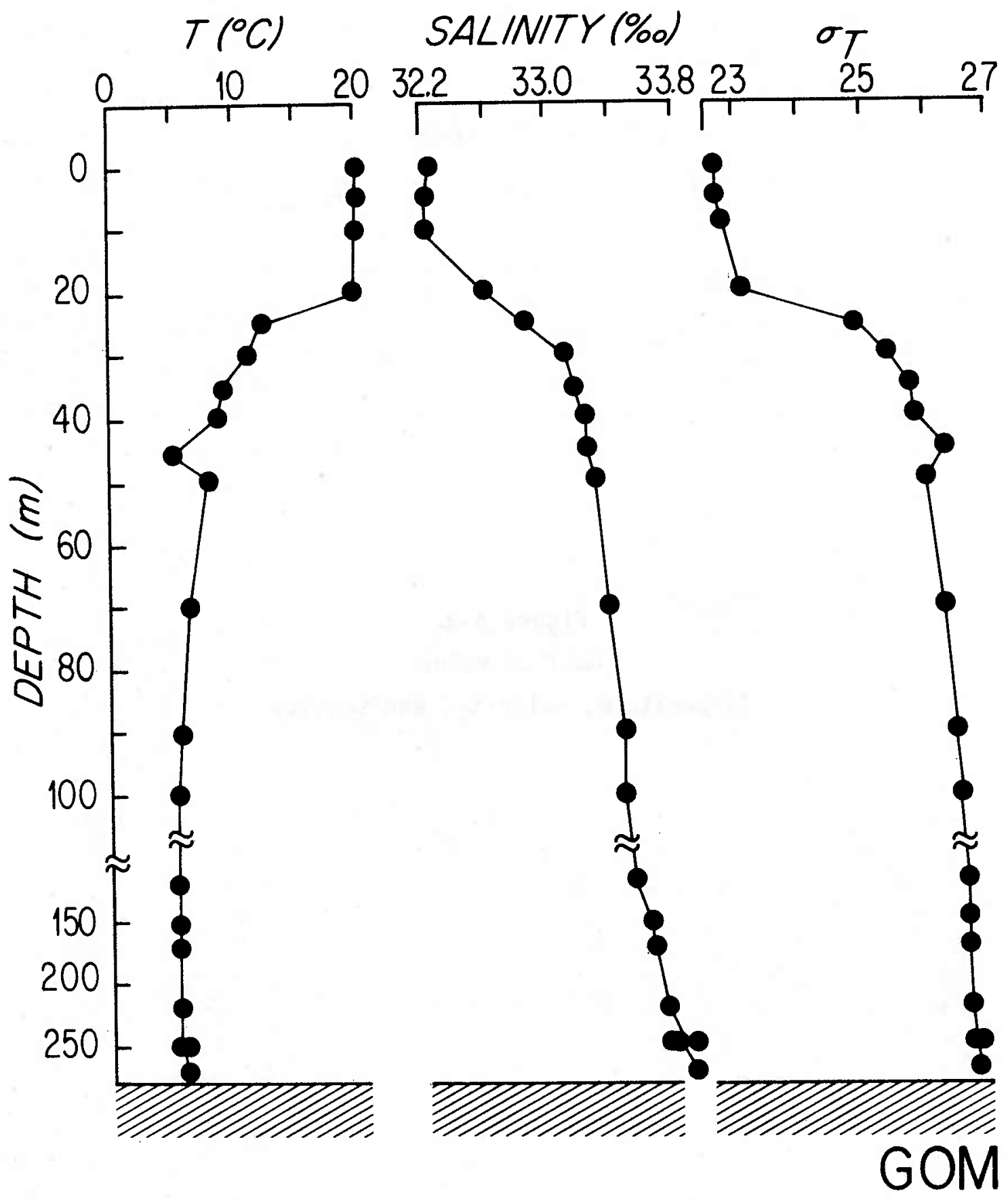


Figure 4-3. Gulf of Maine Nitrate-plus-Nitrite and Ammonia Concentrations 


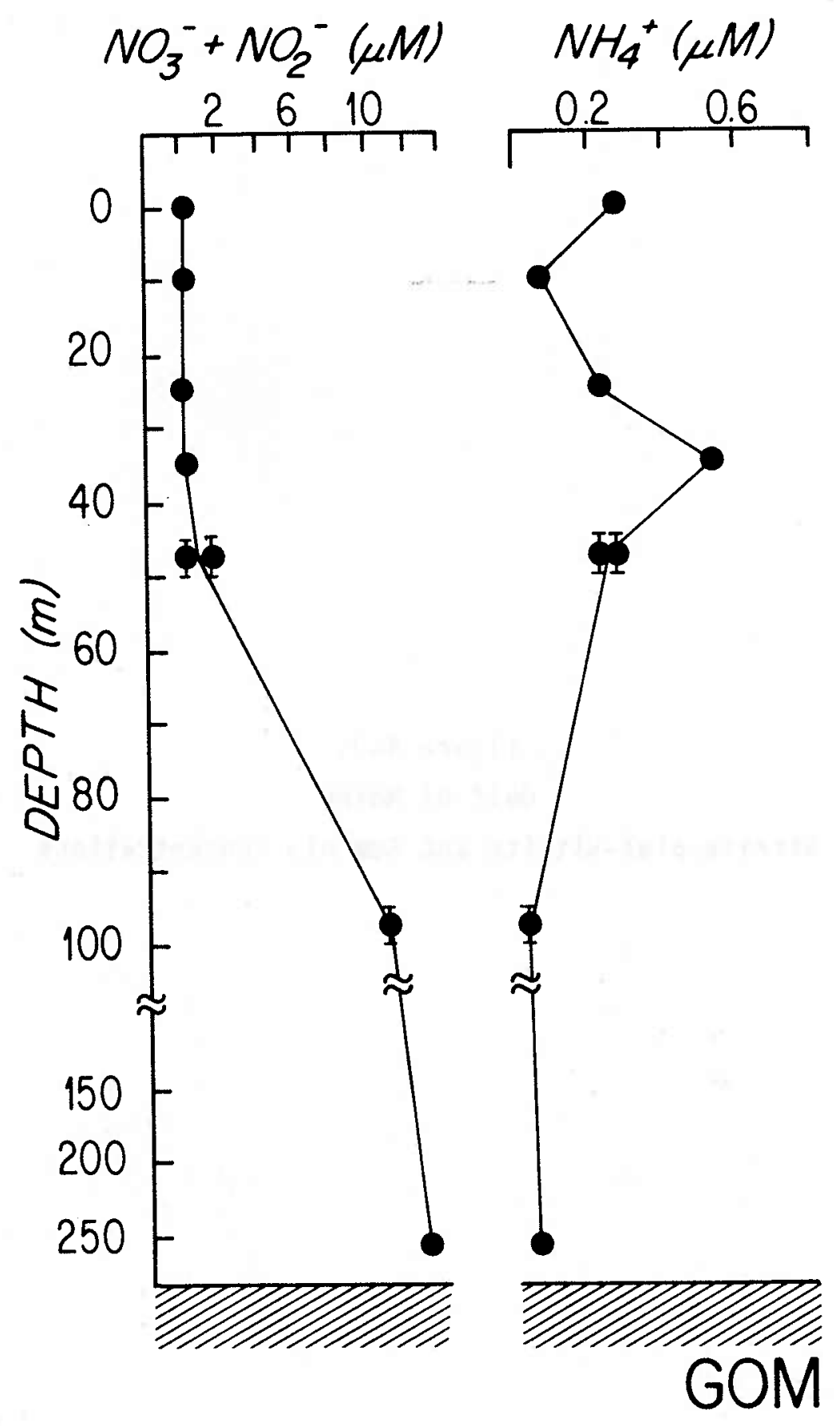


Figure 4-4.

Gulf of Maine

Dissolved Organic Nitrogen, Total Dissolved Nitrogen, Silicate, Phosphate, and 0xygen Concentrations 


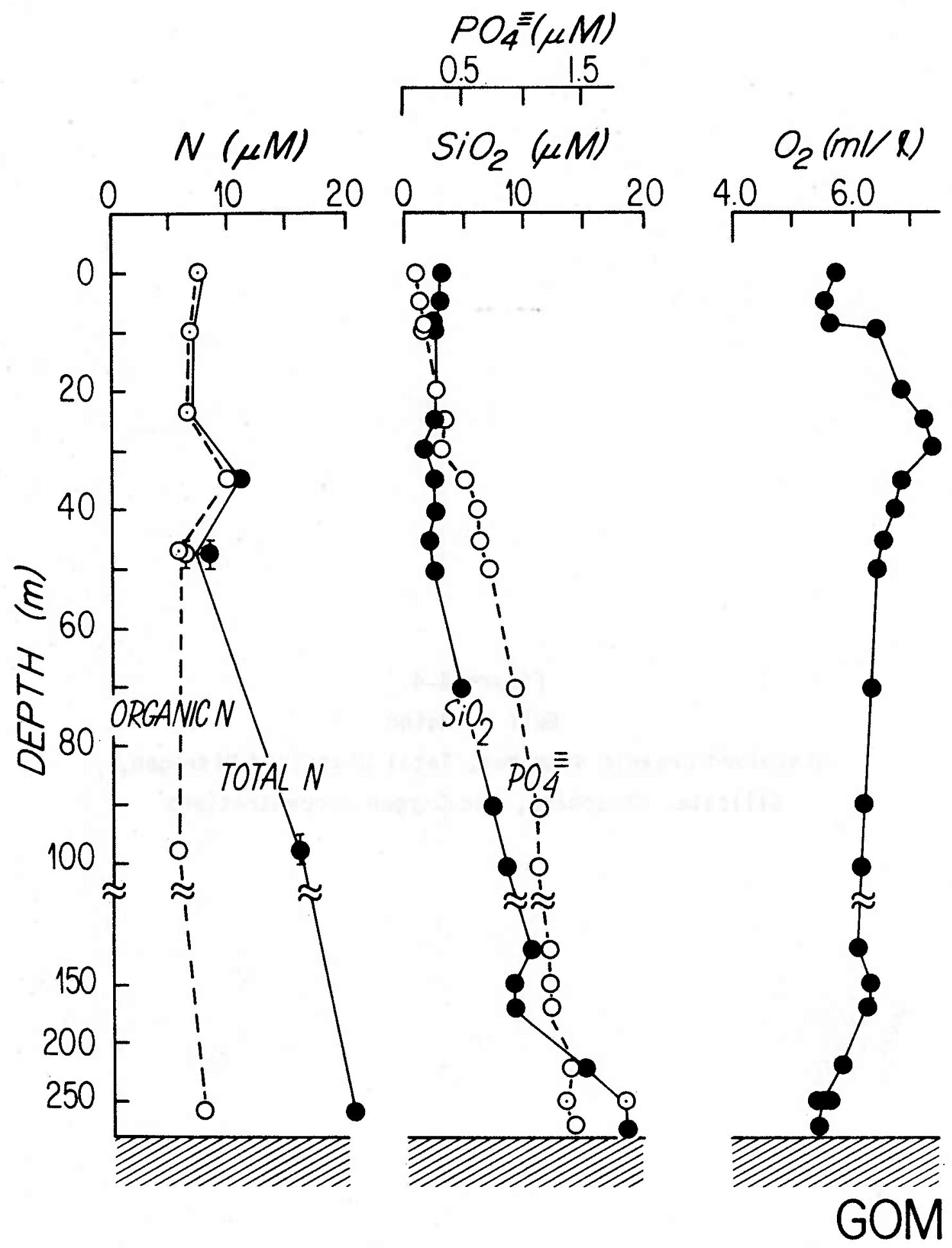


Table 4-1.

Plankton from the Gulf of Maine:

Percent Organic Nitrogen and Carbon, $\mathrm{C} / \mathrm{N}$ Ratio, $\delta^{15} \mathrm{~N}$, and $\delta^{13} \mathrm{C}$

\begin{tabular}{|c|c|c|c|c|}
\hline Sample & Percent $N$ & Percent C & $C / N$ & $\begin{array}{l}\delta^{15} N \\
(0 / 00)\end{array}$ \\
\hline
\end{tabular}

$\begin{array}{lrrrrr}\text { Bu } 1 \mathrm{k} & 6.6 & 35.5 & 6.3 & +5.2 & -19.0 \\ >10 \mu \mathrm{m} & 10.0 & 37.9 & 4.4 & +5.1 & -20.8 \\ <10 \mu \mathrm{m} & 3.0 & 12.4 & 4.9 & +5.4 & -22.2\end{array}$


DeNiro and Epstein (1977) and Connaughey and McRoy (1979).

The $C / N$ ratio and $\delta 13 C$ of the bulk plankton are not intemediate in value between that of the two size fractions. The lower $C / N$ ratios and lower $\delta 13 \mathrm{C}$ values in the separated plankton suggest that ${ }^{13} \mathrm{C}$ was lost during the sieving procedure. This may have been due to mechanical rupture of the cell membranes during sieving and volatilization of the organic carbon compounds during acid treatment and drying. Though this may have occurred during the sieving of the plankton from Station $B$ in the Peru Upwelling Area, the effects were much less pronounced. The rest of the plankton results do not have this discrepancy (See Table 3-1).

\section{Results and Discussion of Isotopic Analyses of POM}

The POM collected with the in-situ pumps was similar in composition to that collected with the Niskin bottles. The POM from 5 to $50 \mathrm{~m}$ was similar to that collected in the plankton net, being composed mostly of Ceratium and variable amounts of copepods. Below $50 \mathrm{~m}$, the filters contained mostly small ( $<10 \mu \mathrm{m}$ diameter) yellow-brown cells.

As in the Peru Upwelling Area, the isotopic content of the POM varied greatly in the water column, having a range in $\delta 15 \mathrm{~N}$ of +2 to $+110 \% 00$, and in $\delta 13 \mathrm{C}$ of -15 to $-220 / 00$ (Figure $4-5$ ). The $\delta 15 \mathrm{~N}$ of the POM collected from 5 to $50 \mathrm{~m}$ resembled that of the plankton, except at 5 to $10 \mathrm{~m}(+2.50 / 00)$. The $\delta^{13} \mathrm{C}$ of this sample was also 1 ow $\left(-22^{0} / 00\right)$, suggesting that a sjgnificant amount of terrestrial POM was present at 5 to $10 \mathrm{~m}$. The $\delta 15 \mathrm{~N}$ of sediment from two estuaries emptying into the Gulf of Maine varies from +3.5 to $+70 / 00$ (Macko, 1981). If the $15 \mathrm{~N}$ content of estuarine sediments is close to that of terrestrial organic matter, it appears that this organic matter is too $15 \mathrm{~N}$-enriched to be the source of the surface POM. Alternatively, the low $\delta 15 \mathrm{~N}$ may reflect anthropogenic input, as it resembles the $\delta 15 \mathrm{~N}$ of the anthropogenic end member determined by Peters et al., (1978) for California coastal waters. Though the coast of the Gulf of Maine is densely populated, 
Figure 4-5.

Gulf of Maine $\delta^{15} \mathrm{~N}$ and $\delta^{13} \mathrm{C}$ of Plankton, POM, and Surface Sediments $(0-2 \mathrm{~cm})$ 

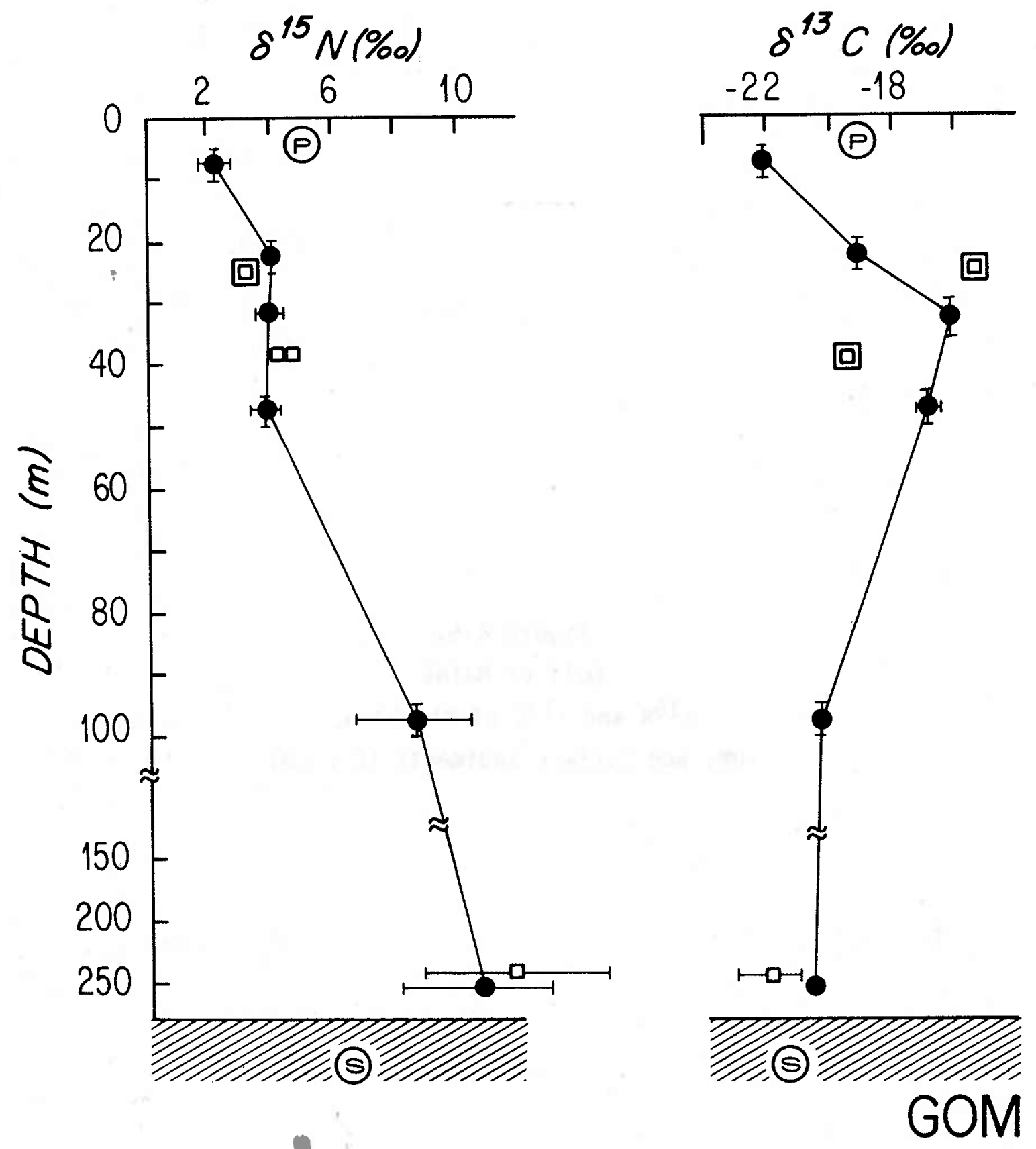
Figure 4-6.

Gulf of Maine

PON and POC Concentrations 

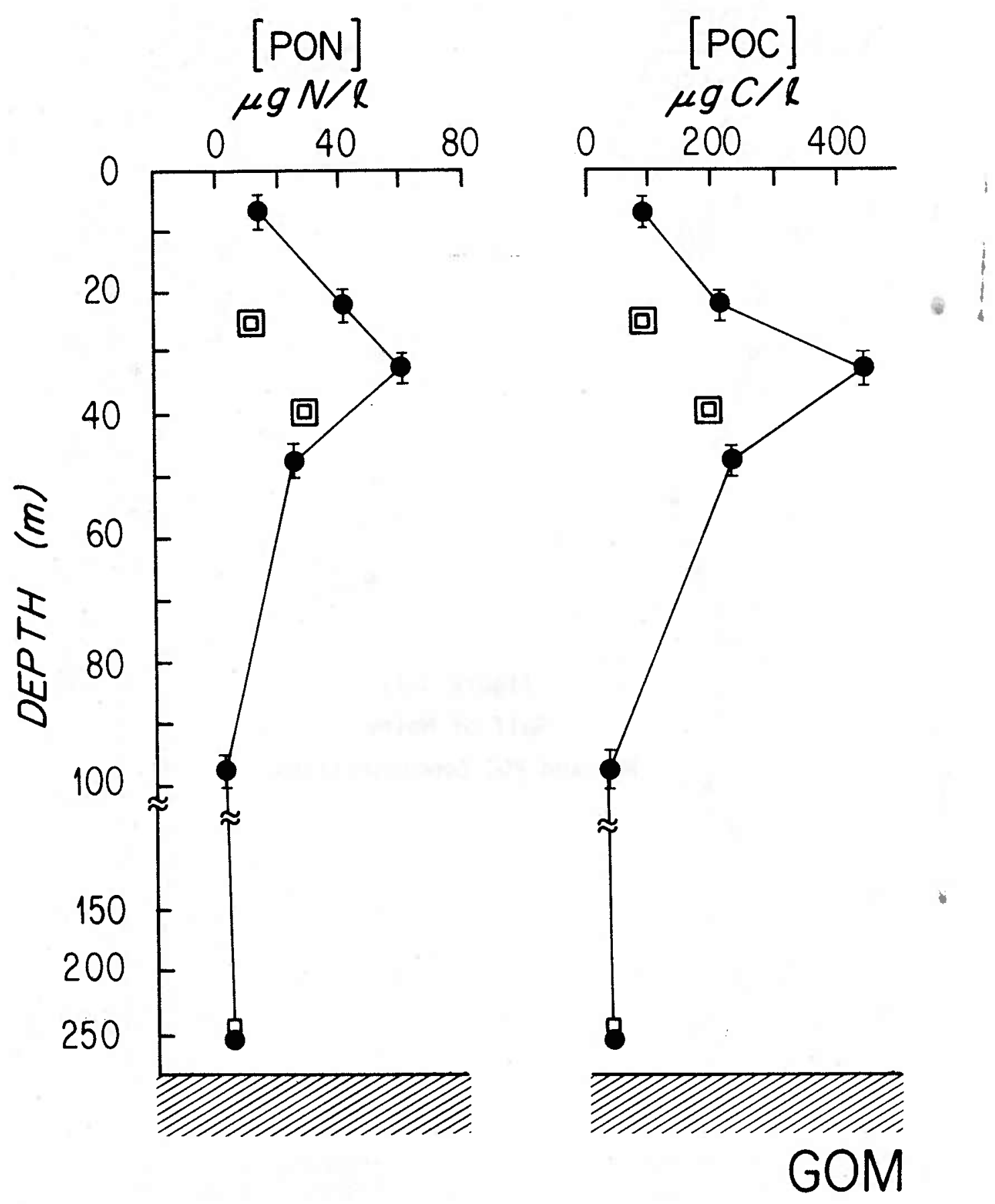
Figure 4-7.

Gulf of Maine

C/N Ratio of Plankton, POM, and

Surface Sediments $(0-2 \mathrm{~cm})$, and Total Particulate Matter Concentrations 

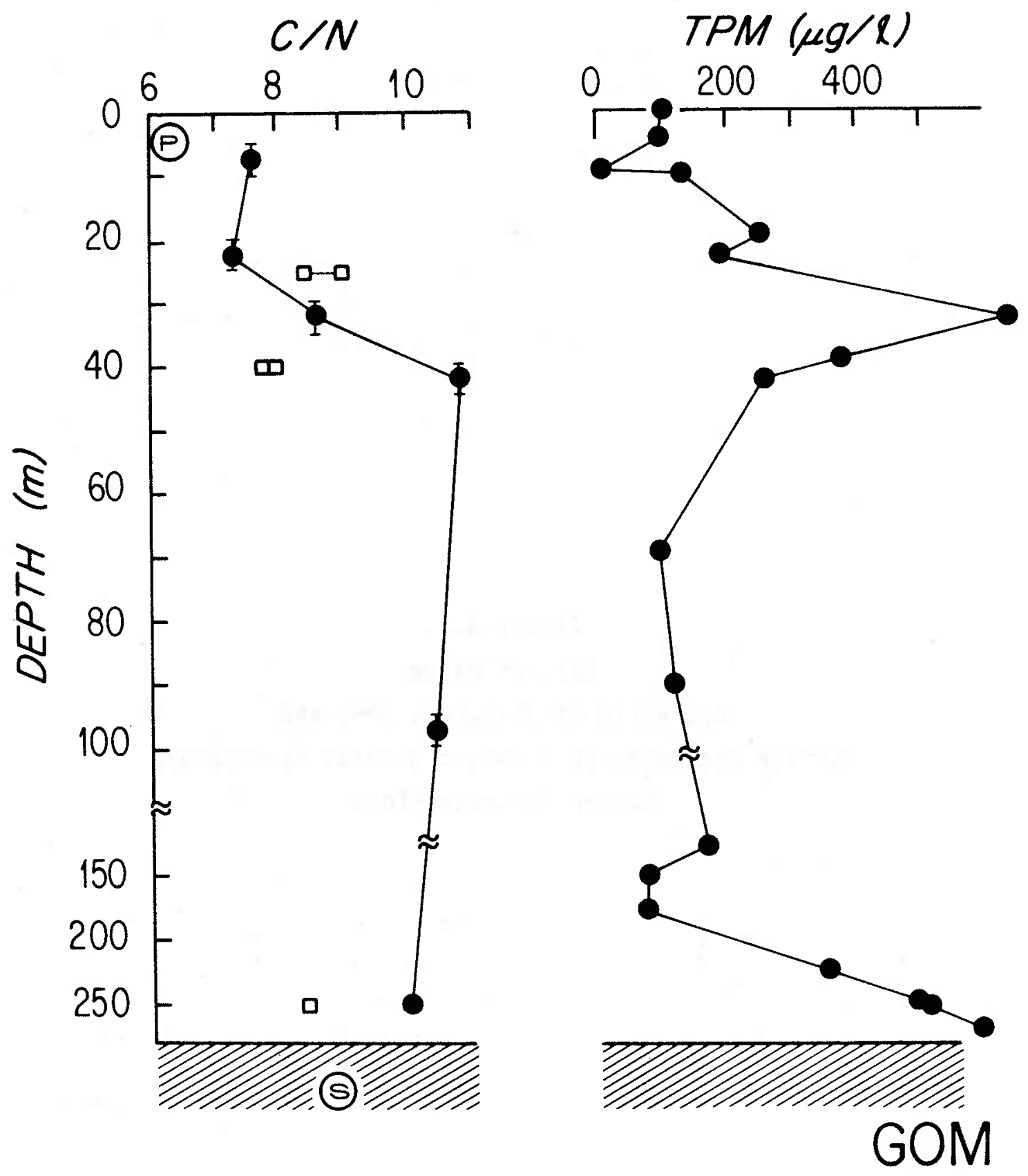
Figure 4-8.

Gulf of Maine

Percent Organic Nitrogen and Carbon of Plankton, POM, and Surface Sediments $(0-2 \mathrm{~cm})$ 


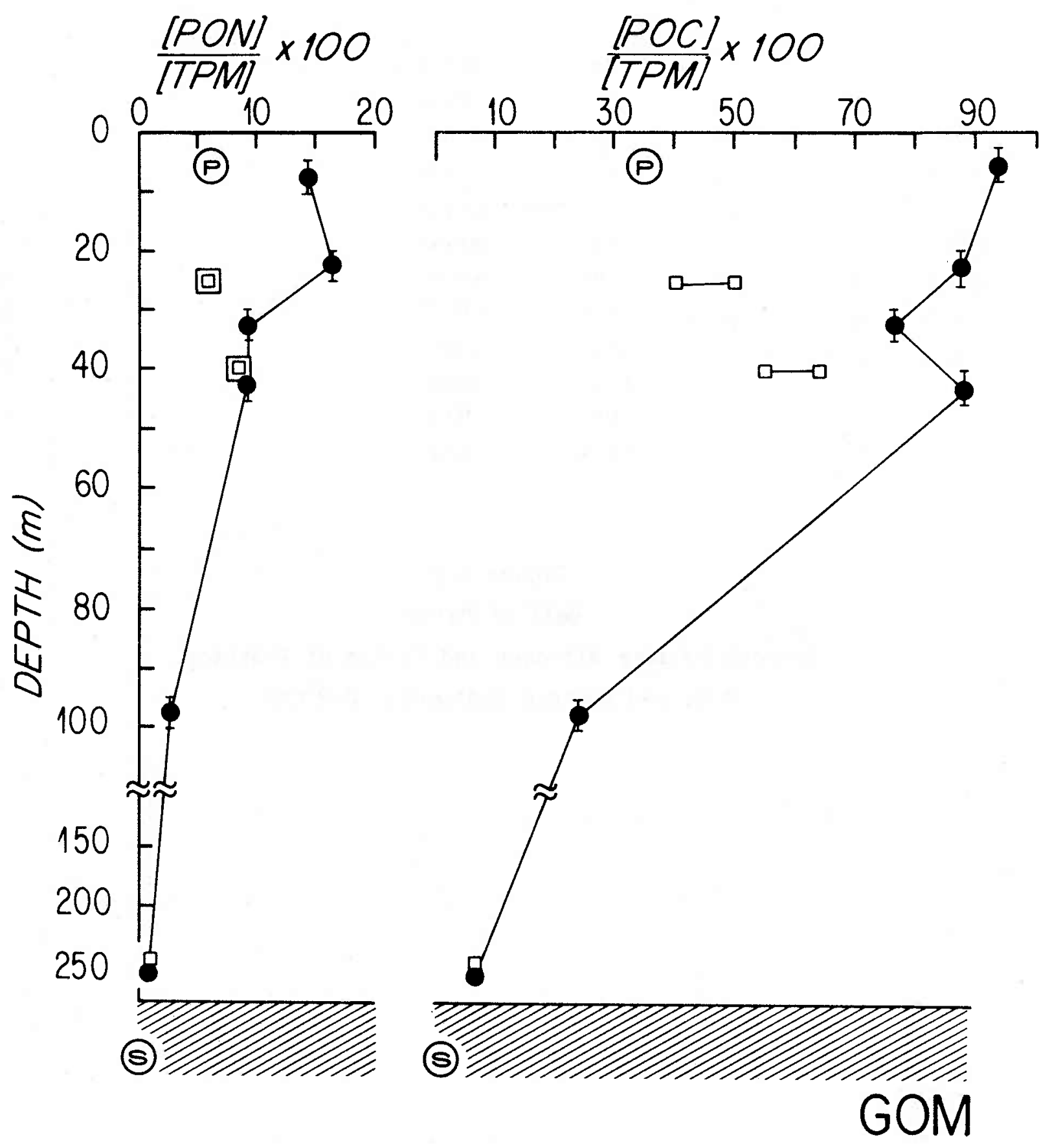


Fitzgerald (1980) has shown that a large fraction of the anthropogenically produced particles is trapped in estuaries.

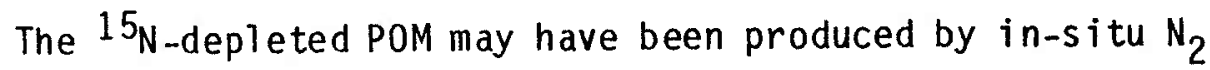
fixation. Azotobacter, a $\mathrm{N}_{2}$-fixing bacterium, was found as a symbiont on Codium fragile, a marine macroalga, collected along the coast of Cape Cod (Head and Carpenter, 1975). The rates of $\mathrm{N}_{2}$ fixation associated with these communities were large enough to suggest that they make a significant contribution to the nitrogen demand of at least the shallow bays fringing the Gulf of Maine. In addition, $\mathrm{N}_{2}$-fixing endosymbionts have been found in the diatom, Rhizoselenia (Mague, 1974), which is common in the Gulf of Maine (Balch, 1981). The possibility of a large effect by these symbionts on the $\delta^{15} \mathrm{~N}$ of the hosts' biomass is suggested by a measurement I made of the $\delta^{15} \mathrm{~N}$ of Sargassum collected from the Sargasso Sea $(+1.6 \%$ ). This alga is al so known to support a community of symbiotic $\mathrm{N}_{2}$ fixers, which excrete DON that is subsequently assimilated by the macro-alga (Jones and Stewart, 1969a; Jones and Stewart, 1969b; Carpenter, 1972). The $15 \mathrm{~N}$ depletion in the Sargassum supports these findings and suggests that a similar process may have produced the $15_{\mathrm{N}}$ depletion of POM found at 5 to $10 \mathrm{~m}$ in the Gulf of Maine.

The increase in the $C / N$ ratio and decreases in POC and PON concentrations with increasing depth, indicate that remineralization of POM had occurred. Below $50 \mathrm{~m}$, the $\delta^{15} \mathrm{~N}$ of the POM increased with increasing depth. The increase in $\delta^{15} \mathrm{~N}$ was similar to that seen by Saino and Hattori (1980) in the northeastern Indian Ocean (Figure 1-6). It also resembles the $\delta^{15} \mathrm{~N}$ increase observed in the initial phase of the controlled decomposition experiments of Wada (1980)(Figure 3-35). This suggests that remineralization in oxic waters causes an $15_{N}$ enrichment in the $\mathrm{POM}$, in contrast to the $15 \mathrm{~N}$ depletion observed in the anoxic and suboxic waters of the Peru Upwelling Area. It should be noted that the deep-water POM in the Gulf of Maine was collected from the bottom nepheloid layer, which was composed in part of reworked 
resuspended sediments. It is assumed that these particles had been subject to degradation in the water column and on the seafloor for long periods of time (See next section for a detailed discussion).

The ${ }^{13} \mathrm{C}$ of the POM is notable for the relatively ${ }^{13} \mathrm{C}$-enriched particles found at 25 to $35 \mathrm{~m}$. The enrichment is similar in extent to that found for the plankton at Station SEAREX. The coincidence of the TPM (Figure 4-7), POC, PON (Figure 4-6), $0_{2}$ (Figure 4-4), ammonia, and DON (Figure 4-3) maxima with the ${ }^{13} \mathrm{C}$ maximum at $35 \mathrm{~m}$ suggests that primary productivity and/or nitrification was responsible for the ${ }^{13} \mathrm{C}$ enrichment. The particle maximum at this depth may have been the result of retention at the density discontinuity at this depth, but the $0_{2}$, ammonia, and DON maxima are evidence for in-situ biological processes. Though Spencer (1975) has found mid-water (140 to $170 \mathrm{~m}$ ) TPM concentration maxima which were attributable to horizontal advection of particles from shallower sediments, no evidence exists for a similar process occurring at depths less than $140 \mathrm{~m}$. There is no indication from visual inspection of the filters that a different assemblage of organisms was present solely at this depth. Thus either bacteria or some metabolic effect associated with primary production may have caused the ${ }^{13} \mathrm{C}$ enrichment.

An example of the 1 atter has been observed by Deuser (1970) in the $\mathrm{B} 1$ ack Sea. The ${ }^{13} \mathrm{C}$ of diatoms collected from an intense bloom was $1.50 \%$ higher than that of phytoplankton from several other stations occupied in the $\mathrm{Black}$ Sea. It was concluded that $\mathrm{CO}_{2}$ uptake by the diatoms was rapid enough to alter the isotopic composition of the dissolved $\mathrm{CO}_{2}$ pool, i.e. faster than isotopic re-equilibration between the $\mathrm{CO}_{2}$ and $\mathrm{HCO}_{3}$ pools could be achieved. Only a small change in ${ }^{13} \mathrm{C}$ was observed, as compared with the 2 to $30 \% 00$ difference between the surface plankton and the POM from 25 to $30 \mathrm{~m}$. The large amount of biological activity apparently taking place between 25 to $30 \mathrm{~m}$ suggests that a process similar to that observed by Deuser (1970) could have caused the ${ }^{13} \mathrm{C}$ enrichment. 
Al ternatively, the ${ }^{13} \mathrm{C}$ enrichment may have been due to 1 arger amounts of protein in the plankton from 25 to $30 \mathrm{~m}$. Morris and Skea (1978) have observed increased rates of $14 \mathrm{C}$ incorporation into protein fractions of phytoplankton from the Gulf of Maine during the summer and at low 1 ight intensities. Degens et a 1. (1968) observed that the $\delta^{13} \mathrm{C}$ of phytoplankton protein varied from -16 to $-19 \%$ oo. Degens found that the relative abundance of protein in the phytoplankton was al so variable, ranging between 14 to 48 percent of the total dry weight. Thus protein-rich phytoplankton at 25 to $30 \mathrm{~m}$ might explain the ${ }^{13} \mathrm{C}$ enrichment.

The $\delta 15 \mathrm{~N}$ values of the POM collected by pump and by Niskin bottle were remarkably similar, but the $\delta^{13} \mathrm{C}$ values were not. However, analyses of the 25-m pump sample corroborated the presence of the $13 \mathrm{C}$-enriched POM collected at 30 to $35 \mathrm{~m}$ with the Niskin bottles. The discrepancy between the carbon isotope results may reflect greater inhomogeneity in the $\delta^{13} \mathrm{C}$ as compared to the $\delta 15 \mathrm{~N}$ of POM. The inhomogeneity could have several causes: 1) The pumps were deployed over 6.5 hours and during a different time of day from when the Niskin cast was made. Diurnal migration of organisms might have changed the $\delta^{13} \mathrm{C}$ of the bulk POM. 2) The carbon isotope content of POM may have been horizontally variable, reflecting patchy distributions of plankton and other POM over short distances. 3) The pumps collect a size spectrum of particles different from the bottles. Bishop et al. (1977) have shown that in the Equatorial Atlantic different size classes of particles have different $\delta^{13} \mathrm{C}$ values. This suggests that the pumps, which are more efficient at collecting large particles, should have produced samples with an isotope content affected by this additional POM.

There is insufficient evidence to determine exactiy which process is important, but is interesting to note that in the surface waters, the POC and PON concentrations of the pump samples were much lower than those of the Niskin bottle samples. In contrast, at 250 to $260 \mathrm{~m}$, close agreement between $\delta 13 \mathrm{C}, \delta^{15} \mathrm{~N}, \mathrm{POC}$, PON, "percent POC and PON" values was found between both sets of samples. This suggests that heterogeneity in the 
surface particles is lost as the POM is degraded to refractory material at depth. The refractory nature of the deep-water particulates was enhanced by the resuspension of sediments. Resuspension supplies reworked sedimentary organic matter to the nepheloid 1ayer, and in addition, keeps the POM at the biologically active sediment/water interface. It is not clear why the $C / N$ ratios of the deep-water bottle (10) and pump (8.5) POM samples were different.

\section{Results and Discussion of Isotopic Analyses of Sediment}

As in the Peru Upwelling Area, the ranges in $\delta^{15} \mathrm{~N}$ and $\delta^{13} \mathrm{C}$ of the sediments from the Gulf of Maine were very small (Figure 4-9) as were the ranges of percent organic nitrogen, percent organic carbon, and $\mathrm{C} / \mathrm{N}$ ratios (Figure 4-10). The organic carbon concentrations fall within the large range of values (0.7 to 2.8) observed by Lyons et al. (1970), Macko (1981), and Henrichs (1980) for the Wilkinson Basin. The $\delta^{15_{N}}$ $\left(+6.3^{\circ} / 00\right)$ and $\delta^{13} \mathrm{C}\left(-21.1^{0} / 00\right)$ of the surface sediments were al so very similar to those determined by Macko (1981) $\left(+6.4\right.$ and $\left.-21.7^{0} / 00\right)$.

Like the sediment data from the Peru Upwelling Area, the Gulf of Maine data fall into a discrete region in plots of $\delta^{15} \mathrm{~N}$ versus $\mathrm{C} / \mathrm{N}$ (Figure $3-43$ ) and $\delta 15_{N}$ versus percent organic nitrogen (Figure $3-44$ ). In view of the 1 arge range in $\delta^{15} \mathrm{~N}, \mathrm{C} / \mathrm{N}$ ratio, and percent organic nitrogen of the POM, the relative constancy of the sedimentary chemical signatures further suggests the importance of benthic biological activity in determining the relatively constant isotope content of the sediments. The $\delta^{15} \mathrm{~N}$ and $\mathrm{C} / \mathrm{N}$ minima, and $\delta^{13} \mathrm{C}$ maximum at 14 to $16 \mathrm{~cm}$ suggest that a change in the $\delta^{15_{N}}$ of the accumulating PON and/or a change in the benthic isotopic alteration occurred during deposition of this layer (Figure 4-9).

In the Gulf of Maine, tidal currents resuspend the surface sediments producing a bottom nepheloid layer with large TPM concentrations. This suggests that the POM which is buried in the sediments has been subject 
$-244-$

Figure 4-9.

Gulf of Maine

Sediments: $\delta^{15_{N}}$ and $\delta^{13} \mathrm{C}$ 


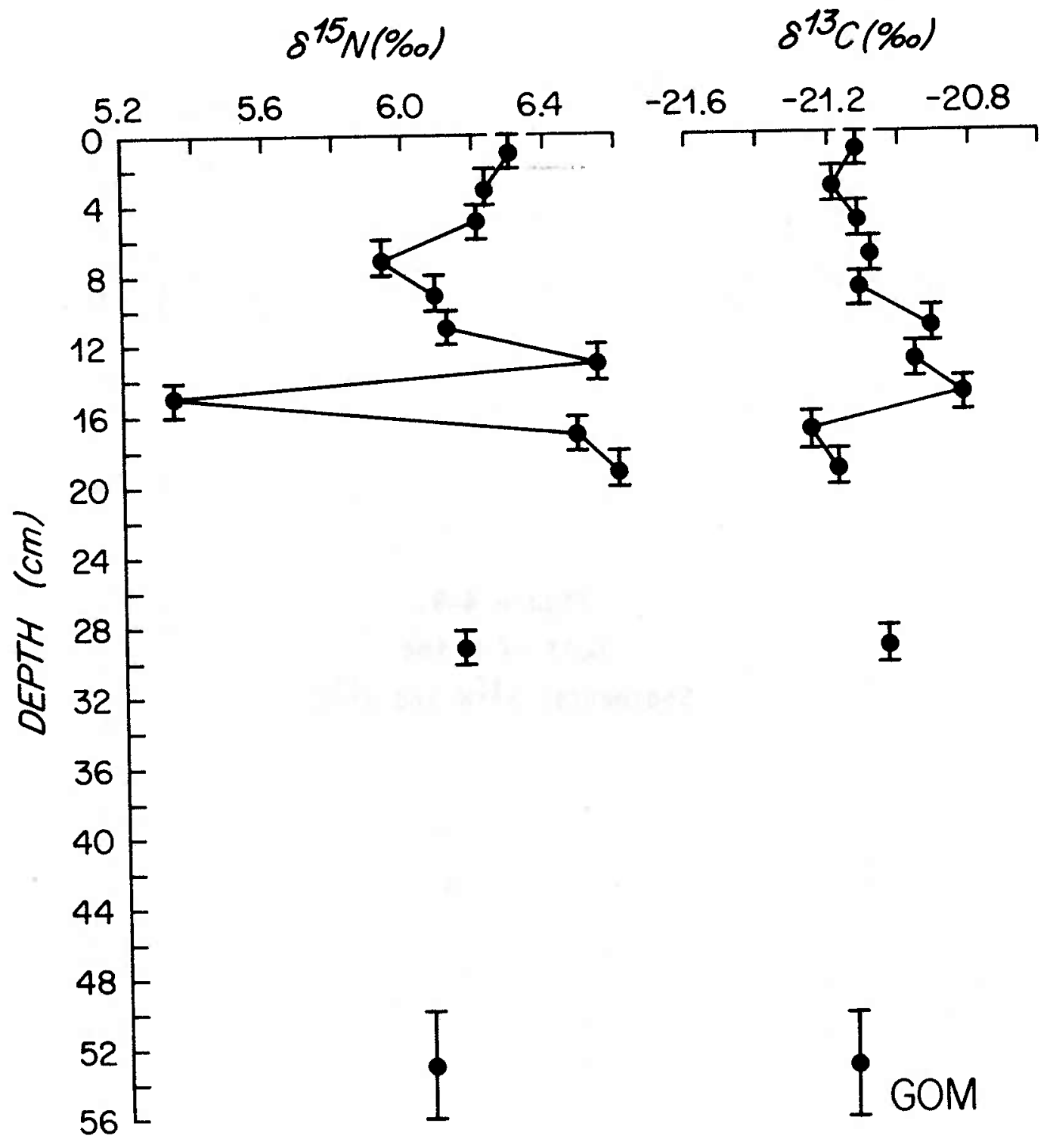


Figure 4-10. Gulf of Maine Sediment: Percent Organic Ni trogen, Carbon, and $\mathrm{C} / \mathrm{N}$ Ratios 

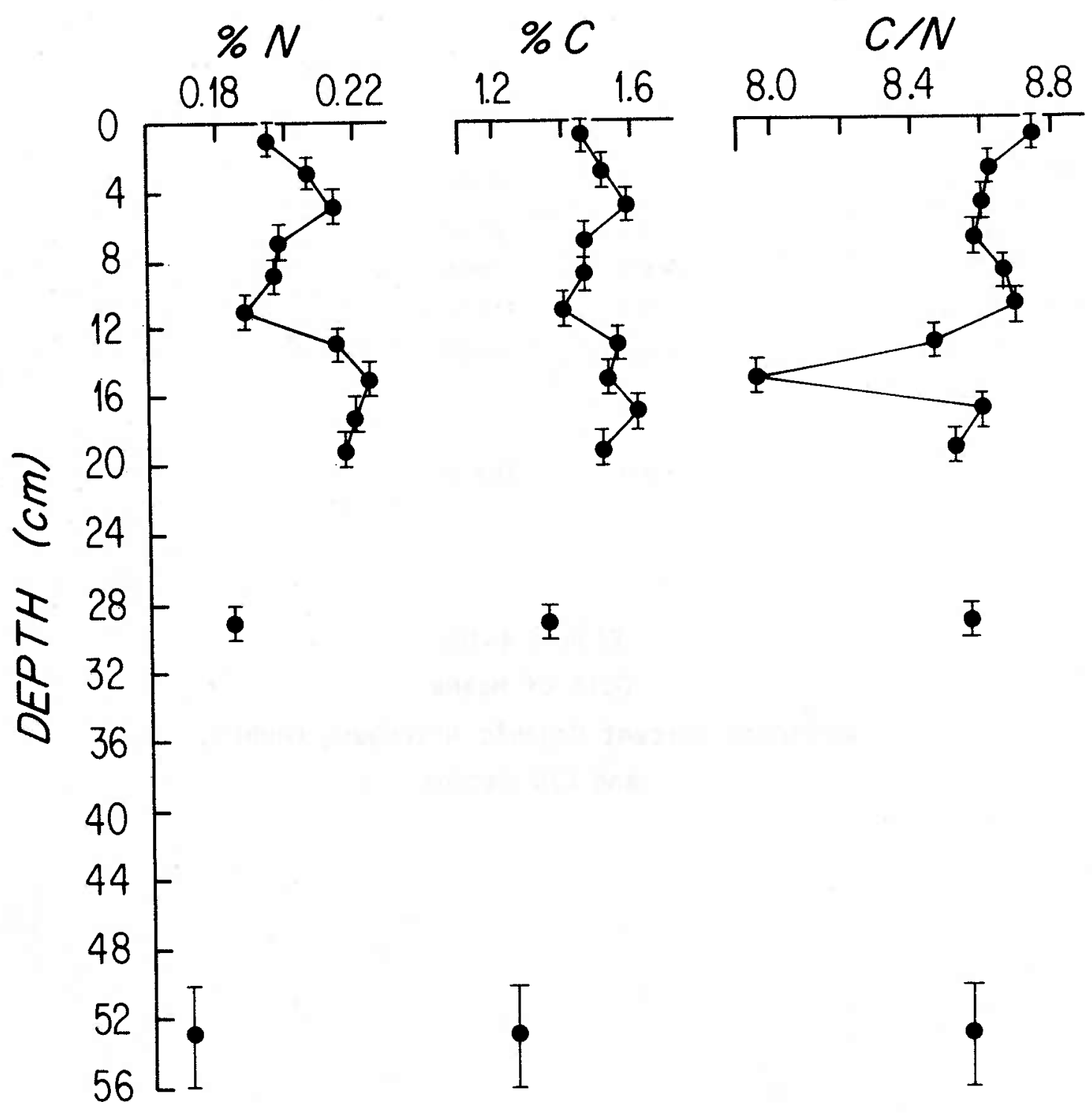
to extensive degradation at the sediment/water interface and may be refractory in nature. As in the Peru Upwelling Area, the deepest POM did not isotopically resemble the $0-2 \mathrm{~cm}$ depth interval of the sediments. Decreases in percent organic nitrogen and carbon and changes in $\mathrm{C} / \mathrm{N}$ ratio between the bottom-water particles and the surface sediments were also observed. This suggests that chemical and isotopic alteration occurred at the sediment/water interface such that the material resuspended was different from the average material in the top two centimeters. On the other hand, POM tends to be mineralized on the seafloor leaving only a small amount of relatively refractory material to be resuspended. Thus, the apparent lability of the deep-water POM suggests that most of the POM in the nepheloid layer is of relatively recent origin. The widespread occurrence of this phenomenon is suggested by the similarity in the $\delta^{15} \mathrm{~N}$ of surface sediments throughout the Gulf of Maine (Macko, 1981) and the geographic spread of the nepheloid layer (Spencer, 1982).

As in the Peru Upwelling Area, the lack of gradients in the organic-matter sedimentary profiles suggests that diagensis was insufficient in magnitude to cause down-core isotopic al teration. Though bioturbation may have been important in homogenizing the organic-matter and isotopic content of the sediments, Lyons et al. (1980) and Henrichs (1980) have shown that the effects of bioturbation are variable or absent in parts of the Gulf of Maine where anoxic sediments have been observed. Unless anoxic sediments are subject to some process which has the same effect as bioturbation on the isotopic distribution in the sediments, then some other process which occurs in anoxic and oxic sediments is causing the small range in $\delta^{15} \mathrm{~N}$ of surface sediment throughout the Gulf of Maine. As suggested earlier, this process may be that of isotopic alteration at the sediment/water interface. It is not suprising that this process may have the dominant effect on the $\delta^{15} \mathrm{~N}$ distribution in the sediments as the organic-matter concentrations change dramatically at the interface.

This interpretation assumes that the $\delta^{15} \mathrm{~N}$ of the sedimenting POM is 
constant. Though the nepheloid 1 ayer apppears to be a permanent feature in the Gulf of Maine, its concentration is variable, perhaps due to changes in tidal current strength and in the amount of bottom-water flushing during the winter ( $M$. Bacon, personal comnunication). In addition, if the $\delta^{15} \mathrm{~N}$ of the vertical particle flux changes seasonally as plankton blooms come and go, the $\delta^{15_{N}}$ of the nepheloid-layer POM may change.

\section{Conclusions and Summary}

As found in the Peru Upwelling Area, the ranges of $\delta^{15} \mathrm{~N}(+2$ to $\left.+12^{0} / 00\right)$ and $\delta^{13} \mathrm{C}\left(-15\right.$ to $\left.-22^{0} \% 0\right)$ in POM, were much 1 arger than those found in the underlying sediments $(+5.2$ to +6.6 and -20.8 to $\left.-21.3^{0} / 00\right)$. The $\delta^{15} \mathrm{~N}$ of plankton from the Gulf of Maine was 4 to $8 \%$ lower than that of plankton from the Peru Upwelling Area, resembling closely the average $\delta^{15} \mathrm{~N}$ of plankton collected from waters where denitrification was unimportant or absent (Figure 3-15). The importance of plankton in determining the $\delta^{15} \mathrm{~N}$ of surface-water POM was suggested by the similarity between the isotopic content of the plankton and the POM except between 5 and $10 \mathrm{~m}$, where terrestrial input and/or nitrogen fixation may have contributed to the 1 ow $\delta^{15_{N}}\left(+2^{0} / 00\right)$ of the POM.

In contrast to the Peru Upwelling Area, the water column in the Gulf of Maine was well oxygenated, having oxygen concentrations near or above saturation values throughout the 280-m water column. The increase in $\delta^{15} \mathrm{~N}$ of the POM with increasing depth suggests that the biological processes associated with the remineralization of POM in oxic waters, i.e. microbial mineralization and zooplankton grazing, caused the $1{ }^{15} \mathrm{~N}$ enrichment. As described earlier, the isotope shifts produced during the decomposition of organic matter are most likely related to the $15_{\mathrm{N}}$ content of the organic nitrogen compounds being degraded. In the Gulf of Ma ine, the PON mineralized to soluble form must have been ${ }^{15} \mathrm{~N}$-depleted, 
causing the residual organic matter to become progressively enriched in $15_{N}$. The high $\delta^{15} \mathrm{~N}$ of POM collected in the oxic deep waters of the northeastern Indian Ocean by Saino and Hattori (1980) further indicate that the process of $15_{\mathrm{N}}$ enrichment is associated with oxic degradation. An increase in $\delta^{15} \mathrm{~N}$ was also observed in the controlled decomposition of PON by Wada (1980) (see Figure 3-35). In the Gulf of Maine, the enhanced effects of 1 ong-term aerobic degradation may have been observed in the high $\delta^{15} \mathrm{~N}$ of the bottom-water P0M which was part of a permanent nepheloid layer of resuspended sediments.

As in the Peru Upwelling Area, the relatively constant $\delta^{15} \mathrm{~N}$, ${ }_{\delta}^{13} \mathrm{C}, \mathrm{C} / \mathrm{N}$ ratios, organic carbon and nitrogen concentrations throughout the sediment core, as well as the differences in these values between the deep-water POM and the surface sediments, suggest that transformation at the sediment/water interface was responsible for imparting the isotope signature to the sediments. The larger $\delta^{15} \mathrm{~N}$ in the deep-water POM with respect to the surface sediments suggests that benthic biological activity in oxygenated waters alters the $\delta^{15_{N}}$ in a fashion different from that in the anoxic bottom waters of the Peru Upwelling Area. As previously suggested for the POM, if specific organic compounds undergoing degradation at the sediment/water interface were $15 \mathrm{~N}$-enriched, their loss through solubilization could have caused the relative ${ }^{15} \mathrm{~N}$ depletion in the sediments. The redox conditions may be important in determining the sequence and mechanism by which specific organic compounds undergo degradation. If this is the case, then the difference in isotopic alteration between the Peru Upwelling Area and the Gulf of Maine may be attributable to decomposition of different organic compounds under suboxic as compared to oxic conditions. 
CHAPTER V:

SUMMARY AND CONCLUSIONS

General Discussion

Isotope studies of nitrogen and carbon were undertaken to investigate the fate of POM during its residence in the water column and after deposition on the seafloor. The processes focused on were water-column transformations and sedimentary diagenesis. Since bacteria are known to be important in both processes, their influence on the isotope chemistry of POM was expected to be important.

The $\delta^{15} \mathrm{~N}$ and $\delta^{13} \mathrm{C}$ of $\mathrm{plankton}$, POM, and sediments from several oceanic sites were related to biological and hydrographic processes identified from nutrient, temperature, and salinity profiles. The sites were chosen to provide samples subject to different specific mineralization processes (nitrification, denitrification, and sulfate reduction), different lengths of water column (duration of the mineralization process), and differences in the magnitude of the organic matter flux. This was done to determine what effect these factors have on the $\delta 15 \mathrm{~N}$ of POM. Four stations were occupied in the upwelling area off the coast of Peru and one station was occupied in the Gulf of Maine. The results of the isotope analyses from the Peru Upwelling Area and the Gulf of Maine are summarized in Figure 5-1 along with the existing $\delta^{15_{N}}$ data from other parts of the world's oceans.

\section{Plankton}

Al though the geographic coverage of the world's oceans is still sparse, it appears that in the northwest Pacific (Wada and Hattori, 1976; Wa da, 1980) the average $\delta^{15} \mathrm{~N}$ of plankton is similar to that found in the Gulf of Maine, while the average $\delta^{15_{N}}$ of plankton from the Peru 
Figure 5-1.

The Geographic Distribution of $\delta^{15} \mathrm{~N}$ in Nitrate, Plankton, POM, and Sediments from

Wa da et a1. (1975)

Wada and Hattori (1976)

Peters et al. (1978)

Sweeney et al. (1978)

Liu (1979)

Saino and Hattori (1980)

Wada (1980)

Macko (1981)

**Reimers (1981)

This Study 


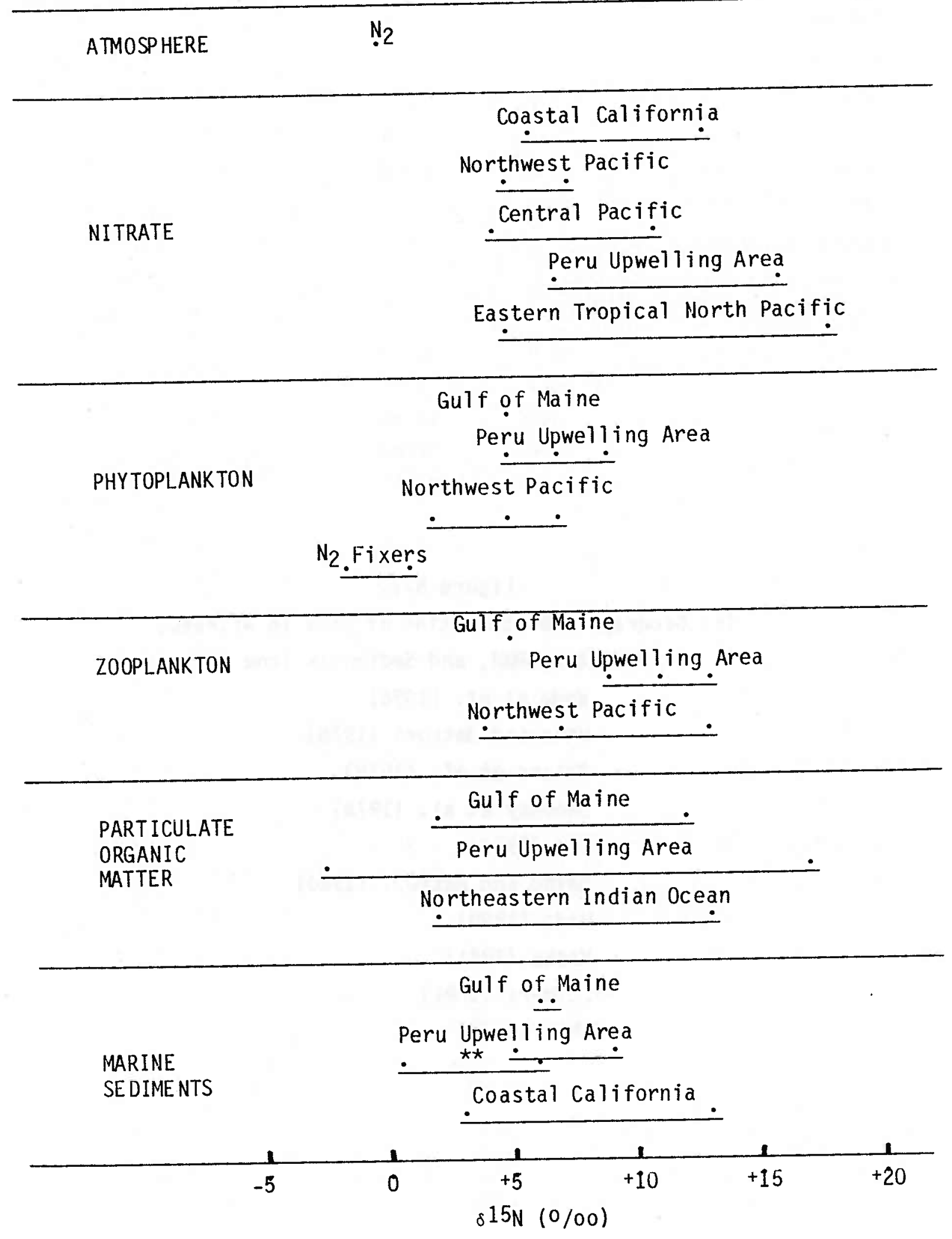


Upwelling Area is similar to that of the plankton from the East Tropical North Pacific (Sweeney et a1. 1978) (See Figures 3-15, 3-16, and 3-17). The higher $\delta^{15} \mathrm{~N}$ of plankton from the Peru Upwelling Area and the East Tropical North Pacific is attributed to the assimilation of

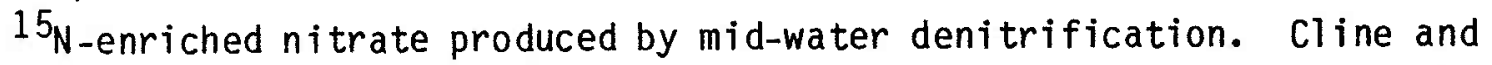
Kaplan (1975) and Liu (1979) have shown that the preferential reduction of the light isotope causes the residual nitrate pool to become enriched in the heavy isotope. In the Peru Upwelling Area, the degree of ${ }^{15} \mathrm{~N}$ enrichment in the plankton appears to be a function of the intensity of denitrification and upwelling which brings the ${ }^{15} \mathrm{~N}$-enriched nutrient nitrate to the surface.

The $\delta^{15} \mathrm{~N}$ of plankton is also affected by the DIN concentrations in the surface waters. Wada and Hattori (1976) have shown that under conditions of nitrogen 1 imitation, the $\delta^{15} \mathrm{~N}$ of plankton is much higher than in the presence of high DIN concentrations. At low concentrations, plankton quantitatively remove the nitrogen from the surface waters producing biomass with a $\delta^{15} \mathrm{~N}$ similar to that of the nitrogen assimilated. At high DIN concentrations, the light isotope is preferentially assimilated.

The temperature profiles from Stations SEAREX and A indicate that upwelled water was present at the sea surface. At Stations SEAREX, A, and $B$, water-column nitrate and nitrite concentration profiles suggest that denitrification had occurred. As shown by Liu (1979), the $\delta^{15} \mathrm{~N}$ of nitrate in the Peru Upwelling Area $\left(+7\right.$ to $\left.+16^{\circ} \% 0\right)$ is higher than that $\left(+5\right.$ to $\left.+11^{\circ} / 00\right)$ found where denitrification is absent (Figure 1-4). The presence of $15 \mathrm{~N}$-enriched nitrate appears to be reflected in the high $\delta 15 \mathrm{~N}(+12$ to $+13 \%$ of plankton from Stations SEAREX and A. At Station $B$, higher surface nitrate concentrations and a well-developed thermocline, which prevented vertical transport of $15 \mathrm{~N}$-enriched nitrate to the surface, may have contributed to the 1 ower $\delta^{15} \mathrm{~N}(+9 \% / 00)$ of the plankton. Al though little denitrification had occurred at Station $C$, the $\delta^{15} \mathrm{~N}$ of the plankton was similar to that found at Station B. This 
may have been due to the effect of $10 \mathrm{~W}$ DIN concentrations. Plankton from the Gulf of Maine were also subject to low DIN concentrations. The lower $\delta 15_{\mathrm{N}}$ of this plankton $(+5 \% / 00)$ is thought to reflect the lower $\delta 15_{\mathrm{N}}$ of nitrate $(+5$ to $+70 / 00)$ in waters where denitrification is absent.

An increase in $\delta 15 \mathrm{~N}$ with increasing trophic level was observed. The $\delta 15 \mathrm{~N}$ of zooplankton were found to be 3 to $4 \%$ oo higher than the $\delta 15 \mathrm{~N}$ of phytoplankton (Figure 3-18). This observation has al so been reported by Miyake and Wada (1967), Wada and Hattori (1976), Pang and Nriagu (1977), and DeNiro and Epstein (1981). As the zooplankton and phytoplankton from the Peru Upwelling Area were also found to be $15_{N}$-enriched with respect to those from the Gulf of Maine and the northwest Pacific, variation in relative zooplankton abundance was not the sole cause of the $15 \mathrm{~N}$ enrichment in plankton from the Peru Upwelling Area.

The $15 \mathrm{~N}$ enrichment with increasing trophic level may have been produced by the preferential excretion of $15 \mathrm{~N}$-depleted ammonia or urea or by production of $15 \mathrm{~N}$-depleted fecal pellets. The $\delta 15 \mathrm{~N}$ of anchovy fecal pellets $(90 / 00)$ collected in sediment traps at Station SEAREX was $40 \%$ lower than that of zooplankton (130/00) from this station. Al though measurements on anchovy biomass were not made, since $\delta 15 \mathrm{~N}$ tends to increase with increasing trophic level, it is likely that the $\delta_{15} \mathrm{~N}$ of the anchovy fecal pellets was more than 4\%/00 lower than the source organism. This seems reasonable as the $\delta 15 \mathrm{~N}$ values of $f i s h$ have been found to range from +10 to $+200 / 00$ (Miyake and Wada, 1967). Thus, isotope mass balance may have been achieved by production of $15 \mathrm{~N}$-depleted fecal pellets. Caution must be used in generalizing this finding to other organisms under different conditions, as $15 \mathrm{~N}$ enrichment in copepod fecal pellets has been observed by Checkley and Entzeroth (1982). 


\section{Particulate Organic Matter}

The $\delta 15 \mathrm{~N}$ of POM from the oxic waters of the Peru Upwelling Area and the euphotic zone of the Gulf of Maine was similar to that of the plankton. This was not surprising as the POM collected on the filters was similar in composition to that collected by plankton tow. The two exceptions were very 1 ow $\delta 15_{N}$ values of POM found at the surface at Station $B$ and at the station in the Gulf of Maine. It is suggested that at Station $B$, bacterial biomass caused the $15_{N}$ depletion and that in the Gulf of Maine $\mathrm{N}_{2}$-fixing symbionts and their algal hosts contributed to the $10 \mathrm{w} \delta 15 \mathrm{~N}$ of surface POM.

In the Peru Upwelling Area, at oxygen concentrations greater than $1 \mathrm{~m} 1 / 1$, the $\delta 15 \mathrm{~N}$ of the POM ranged between +8 to $+12 \% \%$. At concentrations below $1 \mathrm{ml} / 1$, the $\delta 15 \mathrm{~N}$ was extremely variable, ranging from +2.5 to $+170 \%$, with $\delta 15 \mathrm{~N}$ generally decreasing with increasing depth (Figure 3-34). In the Gulf of Maine, where oxygen concentrations were greater than $5 \mathrm{ml} / 1$, the $\delta 15 \mathrm{~N}$ of POM increased with increasing depth. Several mechanisms are suggested to explain these relationships:

1) The particles collected at each depth represent POM synthesized by different organisms at different depths at different times. In this case, $\delta 15 \mathrm{~N}$ variations would represent biological diversity rather than a continuous alteration of the POM as it sinks through the water column. Except for the 1 arge mass of tintinnids found at $40 \mathrm{~m}$ at Station $C$, no filter sample was found to have an assemblage of particles significantly different from that above or bel ow it. The differences observed were in abundance, rather than species composition, and in the state of preservation. The largest differences were observed between samples from above and below the oxycline.

2) Horizontal advection of POM by the Peru Undercurrent may be influential in distributing particles. Since the horizontally-advected particles have been transported under conditions of low oxygen 
concentration, they may have been subject to remineralization processes similar to those occurring on particles which had been vertically transported to the deep waters, differing mainly in the length of time of suboxic degradation. That there is some vertical relationship between the particles throughout the water column, is seen in the PON and POC concentrations, and in the "percent PON and POC" values (See Chapter III: POM Analysis and Sampling for definitions of these terms), which show general decreases with increasing depth, as would be expected for steadily degrading particles.

3) Bacteria and protozoa preferentially remineralize $15_{N}$ in suboxic waters and $14_{\mathrm{N}}$ in oxic waters. There is no evidence in the 1 iterature or from theoretical considerations for such a difference.

4) Bacteria and protozoa are sequentially degrading organic nitrogen compounds which are variably enriched in $15 \mathrm{~N}$. Macko (personal communication) has observed that sedimentary amino acids have different $\delta 15 \mathrm{~N}$ values suggesting that different PON compounds have different $\delta 15 \mathrm{~N}$ values. Al so Wada (1980) has observed that the $\delta 15 \mathrm{~N}$ of decomposing PON varies over time (see Figure 3-35). In the initial phase of decomposition, the $\delta 15 \mathrm{~N}$ increased as PON concentrations decreased to low levels. Further decomposition was accompanied by a decrease in $\delta^{15} \mathrm{~N}$ followed by smaller-amplitude increases and decreases. These changes may be caused by sequential degradation in order of decreasing lability of PON compounds having different $\delta 15_{N}$ values. If so, this may explain why the $\delta 15 \mathrm{~N}$ of POM changes with depth in the water column. If the redox conditions are important in determining the sequence and mechanism by which-specific organic compounds undergo degradation, the difference in isotopic alteration between the Peru Upwelling Area and the Gulf of Maine may be attributable to decomposition of different organic compounds under suboxic as compared to oxic conditions.

5) The possibility of bacterial growth in the second phase of the 
controlled decomposition experiments of Wada (1980) is suggested by the small increases in PON and POC concentrations and decreases in the $\delta^{15} \mathrm{~N}$ of PON. This interpretation is supported by the observation of Macko et al. (1982b) that the $\delta^{15_{N}}$ of bacterial (Anabaena) biomass is 11 to $13 \%$ oo lower than that of its substrate (nitrate). Bacterial growth appeared to be occurring at Station $A$, where small maxima in POC and PON concentrations were present at 35 and $40 \mathrm{~m}$, respectively (Figures 3-22 and $3-24)$. The 1 ow $C / N$ ratios and $\delta^{15} \mathrm{~N}$ of these particles suggested that bacterial synthesis of organic matter contributed significantly to the PON at these depths. Bacterial numbers are sufficiently high in the Peru Upwelling Area (equivalent to 5 to $120 \mu \mathrm{g} / 1$ ) (Sorok in and Kogelschatz, 1979) to generate this kind of effect.

In places like the Peru Upwelling Area, where microbial abundance is high, bacterial growth is expected to be most important in determining the $\delta^{15} \mathrm{~N}$ of particles at 1 ow PON concentrations. Thus, it is not suggested that bacterial activity in oxygen-deficient waters proceeds with greater isotopic fractionation than that achieved in oxic waters, but that the relatively low PON concentrations in the suboxic zone of the Peru Upwelling Area make possible the measureable impact of bacterial biomass on the $\delta^{15} \mathrm{~N}$ of the PON. In addition, the absence of other biological processes in the suboxic waters makes the bacterial signal clearer.

Finally, it is important to note that the majority of the POM samples were collected with 30-1 Niskin bottles. This method of particle collection has been shown to be inefficient at collecting large particles (Gardner, 1976) which make up a significant fraction of the POM flux. The effect of this bias was investigated in the Gulf of Maine by comparing POM collected by the Niskin bottles with POM collected by large-volume in-situ pumps. Though the pumps are probably more efficient at collecting large particles, no significant differences in $\delta^{15_{N}}$ were found between the two sets of POM samples, suggesting that at least in the Gulf of Maine, particle collection by Niskin bottle did not bias the 
$\delta^{15} \mathrm{~N}$ results. In contrast, significant differences in "percent PON and POC", and $\delta^{13} \mathrm{C}$ between the pump and Niskin bottle samples were found at 25 and $40 \mathrm{~m}$, but not at 255 to $260 \mathrm{~m}$. This suggests that heterogeneity in the surface particles is lost as POM is degraded to relatively refractory material at depth.

\section{Sediments}

In contrast to the 1 arge range in $\delta^{15} \mathrm{~N}\left(-2\right.$ to $\left.+17^{\circ} / 00\right)$ of the POM, the range of $\delta^{15} \mathrm{~N}$ in the sediments was small $\left(+5\right.$ to $\left.+9^{0} / 00\right)$. Within a core, the average variation in $\delta^{15} \mathrm{~N}$ was only $1.8^{0} \% 0$. If diagenesis was causing a significant loss of organic matter, profiles of organic carbon and nitrogen contents should show decreases with increasing depth and $C / N$ ratios should increase with increasing depth (Reimers, 1981). Since none of the sedimentary profiles exhibited such trends, it is concluded that diagenesis in these short cores was insufficient to erase the percent carbon, $n i$ trogen and $C / N$ ratio signatures generated by the POM flux and alterations at the sediment/water interface.

The ultimate source of nitrogen to the sediments is POM. It was observed that the $\delta^{15} \mathrm{~N}$ of the deepest POM did not resemble that of the $0-2 \mathrm{~cm}$ depth interval in the sediment, except perhaps at Station $C$. This difference in isotopic content may be due to alteration at the biologically active sediment/water interface, to bioturbation in the oxic cores, and to temporal variability in the $\delta^{15_{N}}$ of P0M in short water columns. As regards the first possibility, Reimers (1981) has shown that a significant fraction of $P O C$ and PON is mineralized at the sediment/water interface in the Peru Upwelling Area. This suggests that the interface may be a site of extensive isotopic alteration.

The down-core constancy in $\delta^{15} \mathrm{~N}, \delta^{13} \mathrm{C}$, percent organic nitrogen and carbon and $\mathrm{C} / \mathrm{N}$ ratio could have been produced by bioturbation, at least in the oxic cores, but this requires that processes causing a 
similar isotope alteration had occurred throughout the deposition of $72 \mathrm{~cm}$ of sediment, the deepest sample analyzed.

It is difficult to assess whether bioturbation is the cause of the down-core variations, though the following observations suggest that the effects of bioturbation may produce down-core variations in $\delta 15 \mathrm{~N}$.

First, Reimers (1981) has shown that unconformities in the Peru Upwelling Area sediments result from changes in bottom circulation which may have caused changes in the benthic environment and thus in benthic activity. Secondly, lithological discontinuities may present barriers or hindrances to bioturbation. This may occur when current scouring removes enough of the overlying sediment to bring the 1 ithological discontinuity back into the zone of bioturbation.

As compared to other coastal areas, the benthic biomass in the Peru Upwelling Area is very large ( 8 to $2000 \mathrm{mg} \mathrm{C} / \mathrm{m}^{2}$ ) and patchily distributed (Rowe, 1971). In addition to the work of Rowe (1971), Reimers (1981) and Henrichs (1980) have al so observed the effects of relatively lower benthic activities in the mud lens located on the shelf break from 11 to $14^{\circ} \mathrm{S}$, than in its 1 andward and seaward edges (Figure 3-36). The anoxic sediments in the mud lens may be subject to less bioturbation, but the ubiquitous presence of Thioploca suggests that bacterial activity is significant in these sediments. At Station $B$, located on the shelf break, the sedimentary $\delta 15 \mathrm{~N}$ values were very $10 \mathrm{w}$ $(+4.6$ to $+6.00 / 00)$. Reimers $(1981)$ has al so reported 1 ow $\delta 15 \mathrm{~N}(+0.5$ to $+6 \%$ ) in the sediments from this area. Since this was considerably lower than that found at the other stations in the Peru Upwelling Area where Thioploca was not present, it is suggested that the benthic activity at this station was different, producing a unique $\delta 15_{\mathrm{N}}$ signature.

The possibility of temporal variability in the deep-water POM must be considered. Two processes may contribute to this. First, the upwelling 
off Peru is variable, causing changes in particle flux as organisms respond to changing nutrient concentrations and temperature. An example of variations in hydrographic conditions which give rise to anomalous chemical and biological conditions was observed at Station $A$ where the production of hydrogen sulfide was observed in the water column. Though hydrogen sulfide production has been reported in the past, the event is infrequent, suggesting that the POM collected at Station A may have had an unusual $\delta 15_{N}$ associated with sulfate reduction.

On the other hand, the long-term constancy of the mid-water oxygen minimum and the secondary nitrite maximum off the coast of Peru (Codispoti and Packard, 1980) suggest that the 1 ow $\delta^{15} \mathrm{~N}$ of the POM from the sub-oxic deep waters and the high $\delta^{15} \mathrm{~N}$ of the plankton is characteristic of this area. Another suggestion of temporal constancy in deep-water POM is seen in the POM analyses from the Gulf of Maine. At this location, the particles caught with Niskin bottles and in-situ pumps had similar $\delta^{15} \mathrm{~N}$ values though the pumps probably collect a different size spectrum of particles. This suggests that rapidly-sinking particles, caught more efficiently by pumps than by bottles, are undergoing isotopic alteration similar to the smaller particles, i.e. bacterial remineralization is homogenizing the $i$ sotopic content of the POM such that variations in the $\delta^{15} \mathrm{~N}$ of surface POM are lost at depth. If the bacterial activity remains constant in the deep waters, so should the $\delta^{15} \mathrm{~N}$ of POM over time.

A second source of temporal variability that must be considered is fluctuations in the horizontal transport of POM. Reimers (1981) has shown that changes in the bottom current velocity have caused changes in deposition of sediments in the Peru Upwelling Area. Presently, horizontally-advected particles are an important source of organic matter at $15^{\circ} \mathrm{S}$ (Station SEAREX) where the Peru Undercurrent weakens. The sediments at this station had the 1 owest ${ }^{13} \mathrm{C}$ values (Figure $3-37$ ) which were ascribed to the presence of terrestrial organic matter brought 
south by the Peru Undercurrent. The low carbon and nitrogen contents (Figure 3-38) of the sediments beneath the area of intense upwelling at $15^{\circ} \mathrm{S}$ are further indication that the flux of locally-generated POM is diluted by organic-poor detritus, such as clay minerals, transported by the Undercurrent (Reimers, 1981). Furthermore, the $\delta^{13} \mathrm{C}, \delta^{15} \mathrm{~N}$, carbon and nitrogen concentrations covary down-core, suggesting that changes in the relative abundance of horizontally-transported particulate matter were recorded in the sediments. Since $E 1$ Niño events are associated with increased input of terrestrial debris due to torrential rainfal1, these phenomena may have led to deposition of the layers having low $\delta^{13} \mathrm{C}$ and high $\delta^{15} \mathrm{~N}$ values, and low organic-matter content. A similar relationship among the sedimentary profiles was not seen at the other on-shore station, as current scouring at $12^{\circ} \mathrm{S}$ (Station A) prevents the kind of deposition found at $15^{\circ} \mathrm{S}$.

In the Gulf of Maine, tidal currents resuspend the surface sediments producing a bottom nepheloid layer with large TPM concentrations. This suggests that the POM which is buried in the sediments has been subject to extensive degradation at the sediment/water interface and may be refractory in nature. As in the Peru Upwelling Area, the deepest POM did not isotopically resemble the $0-2 \mathrm{~cm}$ depth interval of the sediments. Decreases in percent organic nitrogen and carbon and changes in $\mathrm{C} / \mathrm{N}$ ratio between the bottom-water particles and the surface sediments were also observed. This suggests that chemical and isotopic alteration occurred at the sediment/water interface such that the material resuspended was different from the average material in the top two centimeters. On the other hand, POM tends to be mineralized on the seafloor leaving only a small amount of relatively refractory material to be resuspended. Thus, the apparent lability of the deep-water POM suggests that most of the POM in the nepheloid 1 ayer is of relatively recent origin. The widespread occurrence of this phenomenon is suggested by the similarity in the ${ }_{\delta} 15_{\mathrm{N}}$ of surface sediments throughout the Gulf of Maine (Macko, 1981) and the geographic spread of the nepheloid layer (Spencer, 1982). 
As in the Peru Upwelling Area, the lack of gradients in the organic-matter sedimentary profiles suggests that diagenesis was insufficient in magnitude to cause down-core isotopic alteration. Though bioturbation may have been important in homogenizing the organic-matter and isotopic content of the sediments, Lyons et al. (1980) and Henrichs (1980) have shown that the effects of bioturbation are variable or absent in parts of the Gulf of Maine where anoxic sediments have been observed. Uniess anoxic sediments are subject to some process which has the same effect as bioturbation on the isotopic distribution in the sediments, then some other process which occurs in anoxic and oxic sediments is causing the small range in $\delta^{15} \mathrm{~N}$ of surface sediment throughout the Gulf of Maine. As suggested earlier, this process may be that of isotopic al teration at the sediment/water interface. It is not suprising that this process may have the dominant effect on the $\delta 15_{\mathrm{N}}$ distribution in the sediments as the organic-matter concentrations change dramatically at the interface. This interpretation assumes that the $\delta 15 \mathrm{~N}$ of the sedimenting POM is constant. Though the nepheloid layer apppears to be a permanent feature in the Gulf of Maine, its concentration is variable, perhaps due to changes in tidal current strength and in the amount of bottom-water flushing during the winter (M. Bacon, personal communication). In addition, if the $\delta 15 \mathrm{~N}$ of the vertical particle flux changes seasonally as plankton blooms come and go, the $\delta 15 \mathrm{~N}$ of the nepheloid-layer POM may change.

At Station $C$ in the Peru Upwel ling Area, low rates of primary productivity ( $<0.1 \mathrm{~g} \mathrm{C} \mathrm{m}^{-2} \mathrm{~d}^{-1}$, Zuta and Guillén, 1970) and the great length of the water column cause low sedimentation rates and $10 \mathrm{w}$ sedimentary organic-carbon and nitrogen contents. Because of the slow sedimentation rates, the sediments sampled represent a long time interval over which diagenesis may have significantly altered the isotope content of the organic matter. In addition, bioturbation may have been important in redistributing the isotope content of the sediments. On the other hand, the increase in percent carbon and nitrogen with increasing depth in the sediments suggests that at least a partial record of changes in 
POM flux to the sediments and/or transformation at the sediment/water interface has been retained by the sediments.

The isotope profiles at Station $C$ are unique in comparison to those of the other stations, as the $\delta 15 \mathrm{~N}$ and $\delta 13 \mathrm{C}$ decreased with increasing depth in the core. These 1ong-term trends are suggestive of the effects of significant post-depositional alteration. If diagenetic mineralization of organic matter was occurring, it was insufficient to erase the trend of nigher organic content in the POM flux when the older sediments were deposited. Thus the trends in $\delta^{13} \mathrm{C}$ and ${ }^{15} \mathrm{~N}$, if diagenetic in nature, must have been produced by very significant isotopic alteration of a small part of the bulk sedimentary organic carbon and nitrogen. If not, long-term changes in the $\delta 15 \mathrm{~N}$ and $\delta^{13} \mathrm{C}$ of the accumulating POM may have occurred. Changes in benthic activity over time may also have caused the trends. For example as suggested earlier, bioturbation may vary down-core and over time.

In summary, it has been shown that temporal variability in the $\delta 15 \mathrm{~N}$ of sedimenting POM and benthic activity appear to be important in deternining the $\delta 15 \mathrm{~N}$ of the sediments. Temporal variability in the $\delta 15_{\mathrm{N}}$ of bottom-water POM is attributed to changes in deep-water currents which transport POM horizontally and to changes in microbial activity in the water column. The importance of benthic alteration is suggested by the changes in organic matter and isotopic content between the deepest particles and the surface sediments. Furthermore, the relatively constant down-core values suggest that benthic alteration at the sediment/water interface may be important. Bioturbation may al so be influence the distribution of $\delta^{15_{N}}$ in oxic sediments.

In conclusion, this thesis represents a first attempt to investigate the fractionation of the stable isotopes of nitrogen in POM during its transport to the seafloor. It has been shown that $\delta^{15} \mathrm{~N}$ is a useful tool in studying the geochemistry of particulate organic matter in the marine environment. In addition, it is clear that any interpretation of 
the sedimentary $15 \mathrm{~N}$ record must include consideration of isotopic alteration associated with bacterial remineralization of POM and benthic activity.

\section{Future Work}

As is the case with most research, more questions have been raised by this work than have been answered. One of the aims of this thesis was to begin to evaluate whether sedimentary $\delta 15_{\mathrm{N}}$ profiles are records of changes in depositional history. The first step has been to identify the processes which may be important in determining the $\delta 15_{N}$ distributions in the sediments. They are:

1) Temporal variability in the $\delta^{15} \mathrm{~N}$ of accumulating POM,

2) Bioturbation,

3) Isotopic alteration at the biologically active sediment/water interface, and

4) Down-core diagenesis.

The possibility of temporal variability in sedimenting POM should be investigated by time-series sampling such as done by Deuser and Ross (1980). The effects of bioturbation on the $\delta^{15} \mathrm{~N}$ distribution in the sediments could be examined by measuring $210 \mathrm{~Pb}$ and other radiotracers (A1ler and Cochran, 1976; Nozaki et a1., 1977) to determine depths of mixing zones. Careful sampling of the sediment/water interface by box-core and diver-emplaced cores would aid in studying the isotopic alterations at the interface.

The effects of down-core diagenesis on the sedimentary $\delta^{15_{N}}$ distribution could be examined by measuring pore-water distributions of nitrate, ammonia, and sulfate to determine depth intervals over which nitrification, denitrification, and sulfate reduction occur (Bender et a1., 1977). These profiles could be used to estimate the amount of sedimentary nitrogen which has been mineralized. This may correlate with the down-core $\delta^{15} \mathrm{~N}$ variations, if a significant amount of decomposition 
has occurred. If different mineralization processes degrade different organic compounds, down-core variations in $\delta^{15} \mathrm{~N}$ may reflect the isotopic distribution in specific organic compounds. On the other hand, the extent of bacterial fractionation may vary among the different mineralization processes causing variations in the $\delta^{15_{N}}$ of the residual sedimentary organic matter. Thus, in addition to chemical characterization of the pore-waters and bulk sediments, it may be necessary to measure the concentrations and $\delta^{15} \mathrm{~N}$ of specific organic compounds, as well as the extent of fractionation achieved by bacteria during different mineralization processes. These measurements may aid in determining whether sedimentary diagenesis causes isotopic alteration.

Al so of importance is the elucidation of the mechanisms responsible for isotopic alteration of POM in the water column. From this preliminary work, it appears that the $\delta^{15_{\mathrm{N}}}$ of specific organic compounds must be measured to understand why the $\delta^{15} \mathrm{~N}$ decreases during suboxic degradation and increases during oxic degradation. Further measurements of the $\delta^{15} \mathrm{~N}$ of microbial biomass and the extent of isotopic alteration during specific microbial processes would be useful in determining the effect of bacteria and protozoa on the $\delta 15 \mathrm{~N}$ of POM.

In addition, the $\delta^{15} \mathrm{~N}$ of ammonia and DON have yet to be investigated. Since plankton are known to preferentially assimilate ammonia and DON under certain conditions, it is important to know the isotopic contents of these nitrogen reservoirs to understand the $\delta^{15} \mathrm{~N}$ of plankton. Furthermore, investigation of the nitrogen isotope mass balance in the water column requires at least some knowledge of the $\delta^{15} \mathrm{~N}$ of these two nitrogen pools. Further efforts should be expended to ascertain the source of the trophic isotope enrichment effect, since excretion of soluble nitrogen and fecal-pellet packaging of organic matter may be important in controlling the $\delta^{15} \mathrm{~N}$ of nutrient nitrogen in the euphotic zone and that of the PON reaching the sediments.

Finally, the samples analyzed in this study were from a restricted 
set of unusual environments. A much broader data base is required before generalizations about the isotope geochemistry of nitrogen in plankton, POM, and sediments from other parts of the world's oceans can be made. 
Alldredge, A. (1979) The Chemical Composition of Macroscopic Aggregates in Two Neretic Seas. Limnol. Ocean. 24, 855-866.

Al ler, R. and Cochran, J. (1976) 234Th/238U Di sequilibrium in Near-Shore Sediment: Particle Reworking and Diagenetic Time Scales. Earth Planet. Sci. Lett. 29, 37-50.

Azam, F. and Hodson, R. (1977) Size Distribution and Activity of Marine Microheterotrophs. Limnol. Ocean. 22, 492-501.

Balch, W. (1981) An Apparent Lunar Tidal Cycle of Phytoplankton Blooming and Community Succession in the Gulf of Maine. J. Exp. Mar. Biol. Ecol. 55, 65-77.

Bender, M., Fanning, K., Froelich, P., Heath, G., and Maynard, V. (1977) Interstitial Nitrate Profiles and 0xidation of Sedimentary Organic Matter in the Eastern Equatorial Atlantic. Science 198, 605-609.

Bishop, J, Edmond, J., Ketten, D., Bacon, M., and Silker, W. (1977) The Chemistry, Biology, and Vertical Flux of Particulate Matter from the Upper 400m of the Equatorial Atlantic Ocean. Deep-Sea Res. 24, 511-548.

Brewer, P., Spencer, D., Biscaye, P., Hanley, A., Smith, C., Kadar, S., and Fredericks, J. (1976) The Distributions of Particulate Matter in the Atlantic Ocean. Earth Planet. Sci. Lett. 32, 393-402.

Brockmann, C., Fahrbach, E., Huyer, A., and Smith, R. (1980) The Poleward Undercurrent along the Peru Coast: 5 to $15^{\circ} \mathrm{S}$. Deep-Sea Res. 27A, 847-856.

Brown, F., Baedecker, M., Nissenbaum, A., and Kaplan, I. (1972) Early Diagenesis in a Reducing Fjord, Saanich Inlet, British Columbia-III. Changes in Organic Constituents of Sediment. Geochim. Cosmochim. Acta $36,1185-1203$.

Capone, D. and Carpenter, E. (1982) Nitrogen Fixation in the Marine Environment. Science 217, 1140-1142.

Caron, D., Davis, P., Madin, L., and Sieburth, J. (1982) Enrichment of Heterotrophic Bacteria and Bacteriovorous Protozoa in Oceanic Macroaggregates. Science 218, 795-797.

Carpenter, E. (1972) Nitrogen Fixation by a Blue-Green Epiphyte on Pelagic Sargassum. Science 178, 1207-1208.

Cauwet, G. (1978) Organic Chemistry of Sea Water Particulates: Concepts and Developments. Oceanol. Acta 1, 99-105. 
Checkley, D. and Enzeroth, L. (1982) Food Type Selection by Particle Grazing Copepods. EOS 63, 53.

Chester, R. and Stoner, J. (1974) The Distribution of Particulate Organic Carbon and Nitrogen in Some Surface Waters of the World Ocean. Mar. Chem. 2 , 263-275.

Cline, J. (1973) Denitrification and Isotopic Fractionation in Contrasting Marine Environments and the Eastern Tropical North Pacific Ocean. Ph.D. Thesis, University of California at Los Angeles, 270pp.

Cline, J. and Kaplan, I. (1975) Isotope Fractionation of Dissolved Nitrate During Denitrification in the Eastern Tropical North Pacific Ocean. Mar. Chem. 3, 271-299.

Cline, J. and Richards, F. (1972) Oxygen Deficient Conditions and Nitrate Reduction in the Eastern Tropical North Pacific. Limnol. Ocean. 17, 885-900.

Codispoti, L. and Packard, T. (1980) Denitrification in the Eastern Tropical South Pacific. J. Mar. Res. 38, 453-477.

Cole, J. (1982) Chemistry and Microbial Abundance of an "Uncompromised" Deep-Sea Sediment Core (4000m; Panama Basin). EOS 63, 91.

Coleman, D. (1981) Tube Cracker for Opening Samples Sealed in Glass Tubing. Ana 1. Chem. 53, 1962-1963.

Connaughey, T. and McRoy, C. (1979) Food-Web Structure and the Fractionation of Carbon Isotopes in the Bering Sea. Mar. Biol. 53, 257-262.

Craig, H. (1953) The Geochemistry of the Stable Carbon Isotopes. Geochim. Cosmochim. Acta 3, 53-92.

Craig, H. (1957) Isotopic Standards for Carbon and 0xygen and Correction Factors for Mass Spectrometric Analysis of Carbon Dioxide. Geochim. Cosmochim. Acta 14, 133-149.

Crisp, P., Brenner, S., Venkatesan, M., Ruth, E., and Kaplan, I. (1979) Organic Chemical Characterization of Sediment Trap Particulates from San Nicolas, Santa Barbara, Santa Monica, and San Pedro Basins, California. Geochim. Cosmochim. Acta 43, 1791-1801.

Degens, E. (1969) Biogeochemistry of Stable Carbon Isotopes. In: Organic Geochemistry (G. Eglinton and M. Murphy, eds.). Springer-Verlag, New York, pp. 304-329.

Degens, E. (1970) Molecular Nature of Ni trogenous Compounds in Seawater and Recent Marine Sediments. In: Symposium on Organic Matter in Natural Waters (D. Hood, ed.). Institute of Marine Science Occasional PubTication No.1, University of Alaska, College, pp. 77-103. 
Degens, E., Behrendt, M., Gotthardt, B., and Reppman, E. (1968) Metabolic Fractionation of Carbon Isotopes in Marine Plankton- II. Data on Samples Collected off the Coasts of Peru and Ecuador. Deep-Sea Res. 15, 11-20.

Degens, E., Guillard, R., Sackett, W., and Hellebust. (1968) Metabolic Fractionation of Carbon Isotopes in Marine P1ankton-I.Temperature and Respiration Experiments. Deep-Sea Res. 15, 1-9.

Delwiche, C. and Bryan, B. (1976) Denitrification. Ann. Rev. Microbiol. 30, $241-262$.

Demaster, D. (1979) The Marine Budgets of Silica and 32Si. Ph.D. Thesis, Yale University, 308pp.

DeNiro, M. and Epstein, S. (1978) Influence of Diet on the Distribution of Carbon Isotopes in Animals. Geochim. Cosmochim. Acta 42, 495-506.

DeNiro, M. and Epstein, S. (1981) Influence of Diet on the Distribution of Nitrogen Isotopes in Animals. Geochim. Cosmochim. Acta 45, 341-351.

Deuser, W. (1970) Isotopic Evidence for Diminishing Supply of Available Carbon During Diatom Bloom in the Black Sea. Nature 255, 1069-1071.

Deuser, W. and Ross, E. (1980) Seasonal Change in the Flux of Organic Carbon to the Deep Sargasso Sea. Nature 283, 364-365.

Dugdale, R., Goering, J., Barber, R., Smith, R., and Packard, T. (1977) Denitrification and Hydrogen Sulfide in the Peru Upwelling Region During 1976. Deep-Sea Res. 24, 601-608.

Eadie, B. and Jeffrey, L. (1973) 13C Analyses of Oceanic Particulate Organic Matter. Mar. Chem. 1, 199-209.

Eadie, B., Jeffrey, L, and Sackett, W. (1978) Some Observations on the Stable Carbon Isotope Composition of Dissolved and Particulate Organic Carbon in the Marine Environment. Geochim. Cosmochim. Acta 42, 1265-1269.

Fass, R. and Nittrouer, C. (1976) Post-depositional Facies Development in the Fine-Grained Sediments of the Wilkinson Basin, Gulf of Maine. J. Sed. Pet. 46, 337-344.

Fellows, D., Karl, D., and Knauer, G. (1981) Large Particulate Fluxes and the Vertical Transport of Living Carbon in the Upper $1500 \mathrm{~m}$ of the Northeast Pacific Ocean. Deep-Sea Res. 28A, 921-936.

Fitzgerald, M. (1980) Anthropogenic Influence of the Sedimentary Regime of an Urban Estuary-Boston Harbor. Ph.D. Thesis, Massachusetts Institute of Technology/ Woods Hole Oceanographic Institution Joint Program in Oc eanography, 297pp. 
Freyer, H. (1978) Seasonal Trends of $\mathrm{NH}_{4}$ and $\mathrm{NO}_{3}^{-}$Nitrogen Isotope Composition in Rain Collected at Julich, Germany. Tellus 30, 83-92.

Gagosian, R., Loder, T., Nigrelli, G., and Love, J. (1983) Hydrographic and Nutrient Data from R/V AII-108, Leg 3, March to April 1981, off the Coast of Peru. WHOI Technical Report, Woods Hole Oceanographic Institution, Woods Hole, (in preparation).

Gagosian R., Nigrelli, G., and Volkman, V. (1982a) Vertical Transport and Transformation of Benthic Organic Compounds from a Sediment Trap Experiment off the Coast of Peru. WHOI Contribution No.5061, Woods Hole Oceanographic Institution, Woods Hole, 32pp.

Gagosian, R., Smith, S., and Nigrelli, G. (1982b) Vertical Transport of Steroid Alcohols and Ketones Measured in a Sediment Trap Experiment in the Equatorial Atlantic ocean. Geochim. Cosmochim. Acta 46, 1163-1172.

Gallardo, V. (1977) Large Benthic Microbial Communities of Sulfide Biota Under Peru-Chile Subsurface Countercurrent. Nature 268, 331-332.

Gardner, W. (1976) Incomplete Extraction of Rapidly Settling Particles from Water Samplers. Limnol. Ocean. 22, 764-768.

Garfield, P., Packard, T., and Codispoti, L. (1979) Particulate Protein in the Peru Upwelling System. Deep-Sea Res. 26, 623-639.

Glibert, P. and Loder, T. (1977) Automated Analysis of Nutrients in Seawater: A Manual of Techniques. WHOI Technical Report 77-47, Woods Hole Oceanographic Institution, Woods HoTe, 4 6pp.

Goldman, J. (1980) Physiological Processes, Nutrient Availability, and the Concept of Relative Growth Rate in Marine Phytoplankton Ecology. In: Primary Productivity in the Sea (P. Falkowski, ed.). Plenum Press, New York, pp. 179-194.

Gordon, D. (1970) A Microscopic Study of Organic Particles in the North Atlantic Ocean. Deep-Sea Res. 17, 175-185.

Gordon, D. (1971) Distribution of Particulate Organic Carbon and Nitrogen at an Oceanic Station in the Central Pacific. Deep-Sea Res. 18, 1127-1134.

Gordon, D. (1977) Variability of Particulate Organic Carbon and Nitrogen along the Hal ifax-Bermuda Section. Deep-Sea Res. 24, 257-270.

Gordon, D., Wangersky, P., Sheldon, R. (1979) Detailed Observations on the Distribution and Composition of Particulate Organic Matter at Two Stations in the Sargasso Sea. Deep-Sea Res. 26A, 1083-1092.

Gormly, J. and Sackett, W. (1975) Carbon Isotopic Evidence for the Maturation of Marine Lipids. Presented at: $7 \mathrm{th}$ International Meeting on Organic Geochemistry, Madrid, 18pp. 
Gowing, M. and Silver, M. (1982) Fecal Pellet Breakdown: An Inside or an Outside Job. EOS 63, 54 .

Graham, J. (1970) Coastal Currents of the Western Gulf of Maine. Inter. Comm. North West Atlantic Fish. 7, 19-31.

Guillén, 0. (1980) The Peru Current System I:Physical Aspects. In: Proceedings of the Workshop on the Phenomenon Known as El Niño (R. Jordan, ed.). UNESCO, Paris, 185-216.

Hafferty, A., Lowman, D., and Codispoti, L. (1979) Joint-II Melville and Isel in Bottle Data Sections March-May 1977, Reference M76-25. Coastal

Upwelling Ecosystems Analysis Technical Report 38, University of Washington,

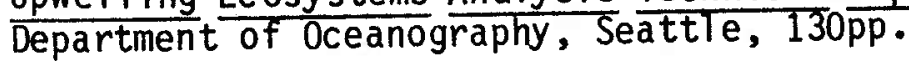

Haines, E. and Montague, C. (1979) Food Sources of Estuarine Invertebrates Analyzed Using ${ }^{13} \mathrm{C} / 12 \mathrm{C}$ Ratios. Ecology $60,48-56$.

Harrison, W. (1980) Nutrient Regeneration and Primary Production in the Sea. In: Primary Productivity in the Sea (P. Falkowski, ed.). Plenum Press, New York, $\overline{\mathrm{pp} .433}-460$.

Head, W. and Carpenter, E. (1975) Nitrogen Fixation Associated with the Marine Macroalga Codium Fragile. Limnol Oceanogr. 20, 815-823.

Hedges, J. (1978) The Formation and Clay Mineral Reactions of Melanoidins. Geochim. Cosmochim. Acta 42, 69-76.

Henrichs, S. (1980) Biogeochemistry of Dissolved Amino Acids in Marine Sediments. Ph.D. Thesis, Massachusetts Institute of Technology/ Woods Hole oceanographic Institution Joint Program in 0ceanography, $253 \mathrm{pp}$.

Hoefs, J. (1980) Stable Isotope Geochemistry. Springer-Verlag, New York, 208pp.

Hoering, T. (1957) The Isotopic Composition of the Ammonia and the Nitrate Ion in Rain. Geochim. Cosmochim. Acta 12, 97-102.

Honjo, S. (1980) Material Fluxes and Modes of Sedimentation in the Mesopelagic and Bathypelagic Zones. J. Mar. Res. 38, 52-97.

Honjo, S. and Roman, M. (1978) Marine Copepod Fecal Pellets: Production, Preservation, and Sedimentation. J. Mar. Res. 36, 45-57.

Jannasch, H. (1973) Bacterial Content of Particulate Matter in Offshore Surface Waters. Limnol. Oceanogr. 18, 340-342.

Jannasch, H., Wirsen, C., and Taylor, C. (1982) Deep-Sea Bacteria: Isolation in the Absence of Decompression. Science 216, 1315-1316. 
Jeffrey, A., Pflaum, R., Brooks, J., and Sackett, W. (1982) Vertical Trends in Particulate Organic Carbon $13 \mathrm{C} / 12 \mathrm{C}$ Ratios in the Upper Water Column. Deep-Sea Res. (submitted).

Jones, K. and Stewart, W. (1969a) Nitrogen Turnover in Marine and Brackish Habitats III. The Production by Calothrix Scopulorum. J. Mar. Biol. Ass., U.K. $49,475-488$.

Jones, K. and Stewart, W. (1969b) Nitrogen Turnover in Marine and Brackish Habitats IV. Uptake of the Extracellular Products of the Nitrogen-Fixing Alga Calothrix Scopulorum. J. Mar. Biol. Ass., U.K. 49, 701-716.

Jorgensen, B. (1977) Distribution of Colorless Sulfur Bacteria (Beggiatoa spp.) in a Coastal Sediment. Mar. Biol. 41, 19-28.

Judkins, D. (1980) Vertical Distribution of Zooplankton in Relation to the Oxygen Minimum off Peru. Deep-Sea Res. 27A, 475-487.

Junk, G. and Svec, H. (1958) The Absolute Abundance of the Nitrogen Isotopes in the Atmosphere and Compressed Gas from Various Sources. Geochim.

Cosmochim. Acta 14, 234-243.

Kangas, R. and Hufford, G. (1974) An Upwelling Rate for Massachusetts Bay. J. Geophys. Res. 79, 2231-2236.

Karl, D. (1982) Microbial Transformations of Organic Matter at Oceanic Interfaces: A Review and Prospectus. EOS 63, 138-140.

Keeney, D. (1973) The Nitrogen Cycle in Sediment-Water Systems. J. Environ. Qua 1. 2, 15-29.

Knauer, G. and Martin, J. (1981) Primary Production and Carbon-Nitrogen Fluxes in the Upper $1500 \mathrm{~m}$ of the Northeast Pacific. Limnol. Oceanogr. 26, $181-186$.

Lee, C. and C. Cronin. (1982) The Vertical Flux of Particulate Organic Nitrogen in the Sea: Decomposition of Amino Acids in the Peru Upwelling Area and the Equatorial Atlantic. J. Mar. Res. 40, 227-251.

Linely, E. and Field, J. (1982) The Nature and Ecological Significance of Bacterial Aggregation in a Nearshore Upwelling Ecosystem. Estuar. Coast. Shelf Sci. 14, 1-11.

Liu, K. (1979) Geochemistry of Inorganic Nitrogen Compounds in Two Marine Environments: The Santa Barbara Basin and the Ocean off Peru. Ph.D. Thesis, University of California at Los Angeles, 354pp.

Lyons, W., Hines, M., Smith, G., and Hewitt, A. (1980) The Biogeochemistry of Sediments in Two Gulf of Ma ine Basins. Mar. Chem. 9, 307-320. 
Macko, S. (1981) Stable Nitrogen Isotope Ratios as Tracers of Organic Geochemical Processes. Ph.D. Thesis, University of Texas at Austin, 180pp.

Macko, S., Estep, M., Engel, M., and Hare, P. (1982a) Stable Nitrogen Isotope Effects in the Transamination of Amino Acids. In: Carnegie Institution of Washington Annual Report 1981-1982 Geophysic al Laboratory (H. Yoder, ed.). Carnegie Institution of Washington, Washington, D.C., pp. 417-421.

Macko, S., Estep, M., and Hoering, T. (1982b) Nitrogen Isotope Fractionation by Blue-Green Algae Cultured on Molecular Nitrogen and Ni trate. Carnegie Institution of Washington Annual Report 1981-1982 Geophysical Laboratory (H. Yoder, ed.). Carnegie Institution of Washington, washington, D.C., pp. 413-416.

Macko, S., Lee, W., and Parker, P. (1982C) Nitrogen and Carbon Isotope Fractionation by Two Species of Marine Amphipods: Laboratory and Field Studies. J. Exp. Mar. Biol. Ecol. 63, 145-149.

Maeda, S. and Kishimoto, R. (1970) Upwelling off the Coast of Peru. J. Oc ean. Soc. Japan 26, 300-309.

Mague, T., Weare, M., and Holm-Hansen, 0. (1974) Nitrogen Fixation in the North Pacific Ocean. Mar. Biol. 24, 109-119.

McCarthy, J., Taylor, W., and Taft, T. (1977) Nitrogenous Nutrition of the Plankton in the Chesapeake Bay. 1. Nutrient Availability and Phytoplankton Preferences. Limnol. Oceanogr. 22, 996-1011.

Miyake, Y. and Wada, E. (1967) The Abundance Ratio of $15 \mathrm{~N} / 14 \mathrm{~N}$ in Marine Environments. J. Ocean. Soc. Japan 9, 37-53.

Miyazaki, T., Wada, E., and Hattori, A. (1980) Nitrogen-Isotope Fractionation in the Nitrate Respiration by the Marine Bacterium Serratia Marinoruba. Geomicrobiol. J. 2, 115-126.

Morita, R., Iturriaga, R., and Gallardo, V. (1981) Thioplocca: Methylotroph and Significance in the Food Chain. Kieler Meeresforsch (Kiel) (in press).

Morris, I. and Skea, W. (1978) Products of Photosynthesis in Natural Popoulations of Marine Phytoplankton from the Gulf of Maine. Mar. Biol. 47, 303-312.

Muller, P. (1977) C/N Ratios in Pacific Deep-Sea Sediments: Effects of Inorganic Ammonium and Organic Nitrogen Compounds Sorbed by Clays. Geochim. Cosmochim. Acta 41, 765-776.

Nissenbaum, A. (1974) The Organic Geochemistry of Marine and Terrestrial Humic Substances: Implications of Carbon and Hydrogen Isotope Studies. In: Advances in Organic Geochemistry (B. Tissot and F. Bienner, eds.). Editions Technip, Paris, pp. 39-52. 
Nozaki, Y., Cochran, J., Turekian, K., and Keller, . (1977) Radiocarbon and $210 \mathrm{~Pb}$ Distribution in Submersible-Taken Deep-Sea Cores from Project FAMOUS. Earth Planet. Sci. Lett. 34, 932-933.

01 son, R. (1981) $15 \mathrm{~N}$ Tracer Studies of the Primary Nitrite Maximum. J. Mar. Res. 39, 203-226.

0'Reilly, J. and Busch, D. (1982) Phytoplankton Production on the Northwest Atlantic Shelf. Rapp. Proc. Verb. Reun. (in press).

Packard, T., Dugdale, R., Goering, J., and Barber, R. (1978) Nitrate Reductase Activity in the Subsurface Waters of the Peru Current. J. Mar. Res. 36, 59-77.

Painter, H. (1970) A Review of the Literature on Inorganic Nitrogen Metabolism in Microorganisms. Water Res. 4, 393-450.

Pak, H., Codispoti, L., and Zaneveld, J. (1980) On the Intermediate Particle Maxima Associated with Oxygen-Poor Water off Western South America. Deep-Sea Res. 27A, 783-797.

Pang, P. and Nriagu, J. (1976) Distribution and Isotope Composition of Nitrogen in Bay of Quinte (Lake Ontario) Sediments. Chem. Geol. 18, 93-105.

Pang, P. and Nriagu, J. (1977) Isotopic Variations of the Nitrogen in Lake Superior. Geochim. Cosmochim. Acta 41, 811-814.

Patzert, W. (1978) El Niño Watch Atlas of Physical, Chemical, and Biological Oceanographic and Meterological Data. SIO Reference Series 78-7, Scripps Institute of Oceanography, San Diego, $3 \overline{22 p p}$.

Peters, K., Sweeney, R., and Kaplan, I. (1978) Correlation of Carbon and Nitrogen Stable Isotope Ratios in Sedimentary Organic Matter. Limnol. Ocean. 23, 598-604.

Quarmby, L. (1982) The Effects of Diet and Bacteria on Measured Rates and Composition of the Nitrogeneous Excretion of Ampithoe Simulans (Crustacea). EOS 65, 964.

Quinn, W., Zopf, D., Short, K., and Kuo Yang, R. (1978) Historical Trends and Statistics of the Southern Oscillation, El Niño, and Indonesian Droughts. Fish. Bul1. 76, 663-678.

Redfield, A., Ketchum, B., Richards, F. (1963) The Influence of Organisms on the Composition of Seawater. In: The Sea, V.2 (N. Hill, ed.). Interscience, New York, pp. 26-77.

Reimers, C. Sedimentary Organic Matter: Distribution and Alteration Processes in the Coastal Upwelling Region off Peru. Ph.D. Thesis, Oregon State University, 219p p. 
Repeta, D. (1982) Transformation of Cartenoids in the Oceanic Water Column. Ph.D. Thesis, Massachusetts Institute of Technology/ Woods Hole Oceanographic Institution Joint Program in Oceanography, 241pp.

Rowe, G. (1971) Benthic Biomass in the Pisco, Peru Upwelling. Investi. Pesq. 35, 127-135.

Rowe, G. and Gardner, W. (1975) Sedimentation Rates in the Slope Water of the Northwest Atlantic Ocean Measured Directly with Sediment Traps. J. Mar. Res. 37, 581-600.

Rowe, G., and Staresinic, N. A Simulation Model of Nitrogen Transformations in Surface Marine Sediments. (in preparation).

Saino, T. and Hattori, A. (1980) 15N Natural Abundance in Oceanic Suspended Matter. Nature 283, 752-754.

Santander, H. The Peru Current System, 2: Biological Aspects. In: Proceedings of the Workshop on the Phenomenon Known as El Niño (R. Jordan, ed.). UNESCO, Paris, 217-228.

Schlitz, R. and Cohen, E. (1982) A Nitrogen Budget for the Gulf of Maine and Georges Bank. EOS 63, 76.

Seizen, R. and Mague, T. (1978) Amino Acids in Suspended Particulate Matter from Oceanic and Coastal Waters of the Pacific. Mar. Chem. 6, 215-231.

Shanks, A. and Trent, J. (1979) Marine Snow: Microscale Nutrient Patches. Limno1. Oceanogr. 24, 850-853.

Silver, M. and Alldredge, A. (1981) Bathypelagic Marine Snow: Deep Sea Algal and Detrital Community. J. Mar. Res. 39, 501-530.

Silver, M., Shanks, A., and Trent, J. (1978) Marine Snow: Microplankton Habitat and Source of Smal1-Scale Patchiness in Pelagic Populations. Science $28,371-373$.

Smith, S. (1978) Nutrient Regeneration by Zooplankton During a Red Tide off Peru with Notes on Biomass and Species Composition of Zooplankton. Mar. Biol. $49,125-132$.

Sorok in, Y. (1978) Description of Primary Productivity and of Heterotrophic Microplankton in the Peruvian Upwelling Region. Oceanol. 18, 62-71.

Sorokin, Y. and Kogelschatz, J. (1979) Analysis of Heterotrophic Microplankton in an Upwelling Area. Hydrobiol. 66, 195-208.

Spencer, D. (1975) The Distribution of Some Chemical Elements Between Dissolved and Particulate Phases in Sea Water. AEC Report No. CO0-3566-11, Atomic Energy Commission, Washington, D.C., 25pp. 
Spencer, D. (1982) The Distribution of Some Chemical Elements Between Dissolved and Particulate Phases in the Ocean. Report to U.S. Department of Energy for 1980-1982. DUE Report No. DOE/EY/03566-39, Department of Energy, Washington, D.C., 14pp.

Spencer, D. and Sachs, P. (1970) Some Aspects of the Distribution, Chemistry, and Mineralogy of Suspended Matter in the Gulf of Maine. Mar. Geo1. 9, 117-136.

Staresinic, N. (1978) The Vertical Flux of Particulate Organic Matter in the Peru Coastal Upwelling as Measured with a Free-drifting Sediment Trap. Ph.D. Thesis, Massachusetts Institute of Technology/ Woods Hole Oceanographic Institution Joint Program in Oceanography, 255pp.

Staresinic, N. (1982) Downward Fl ux of Bulk Particulate Organic Matter in the Peru Coastal Upwelling. J. Mar. Res. (submitted).

Strickland, J. and Parsons, T. (1972). A Practical Handbook of Seawater Analysis. Fisheries Research Board of Canada Bulletin, Ottawa, No. 167, 2nd ed., $310 \mathrm{pp}$.

Stuermer, D., Peters, K., and Kaplan, I. (1978) Source Indicators of Humic Substance and Proto-Kerogen Stable Isotope Ratios, Elemental Compositions, and Electron Spin Resonance Spectras. Geochim. Cosmochim. Acta 42, 989-997.

Suess, E. (1982) Phosphate Regeneration from Sediments of the Peru Continental Margin by Dissolution of Fish Debris. Geochim. Cosmochim. Acta $45,577-588$.

Sugahara, I., Sugiyama, M., and Kawai, A. (1974) Di stribution and Activity of Nitrogen-Cycle Bacteria in Water-Sediment Systems with Different Concentrations of 0xygen. In: Ef fect of the Ocean Environment on Microbial Activities (R. Colwell and R. Moriata, eds.). University Park Press, Baltimore, pp. 327-340.

Sverdrup, H., Johnson, M., and Fleming, R. (1942) The 0ceans. PrenticeHal1, Inc., New Jersey, 1087pp.

Sweeney, R. and Kaplan, I. (1978) Tracing Flocculent Industrial and Domestic Sewage Transport on San Pedro Shelf, Southern California by Nitrogen Isotope Ratios. UCLA Contribution No. 1895, University of California at Los Angeles, Los Angeles, 21pp. (preprint).

Sweeney, R. and Kaplan, I. (1980) Natural Abundance of $15 \mathrm{~N}$ as a Source Indicator for Near-Shore Marine Sedimentary and Dissolved Nitrogen. Mar. Chem. 9, 81-94.

Sweeney, R., Liu, K., and Kaplan, I. (1978) Oceanic Nitrogen Isotopes and their Uses in Determining the Source of Sedimentary Nitrogen. In: Department of Scientific and Industrial Research Bulletin, V.220 (B. Robinson, ed.). Science Information Division, DSIR, Wellington, pp. 9-26. 
Tan, F. and Strain, P. (1979) Carbon Isotope Ratios of Particulate Oceanic Matter in the Gulf of St. Lawrence. J. Fish. Res. Board Can. 36, 678-682.

Turner, J. (1979) Microbial Attachment to Copepod Fecal Pellets and Its Possible Ecological Significance. Trans. Amer. Microsc. Soc. 98, 131-135.

Turner, J. and Ferrante, J. (1979) Zooplankton Fecal Pellets in Aquatic Ecosystems. Bioscience 29, 670-677.

Vanderborght, J., and Billen, G. (1975) Vertical Distributions of Nitrate Concentration in Interstitial Water of Marine Sediments with Nitrification and Denitrification. Limno1. Ocean. 20, 953-961.

Venkatesan, M., Brenner, S., Ruth, E., Bonilla, J., and Kaplan, I. (1980) Hydrocarbons in Age-dated Sediment Cores from Two Basins in the Southern California Bight. Geochim. Cosmochim. Acta 44, 989-802.

Wada, E. (1980) Nitrogen Isotope Fractionation and Its Significance in Biogeochemical Processes Occurring in Marine Environments. In: Isotope Marine Chemistry (E. Goldberg, Y. Horibe, and K. Saruhashi, eds.). Uchi da Rokakuho Co., Ltd. Tokyo, pp. 375-398.

Wada, E. and Hattori, A. (1976) Natural Abundance of $15 \mathrm{~N}$ in Particulate Organic Matter in the North Pacific Ocean. Geochim. Cosmochim. Acta 40, 249-256.

Wada, E., Kadonaga, T., and Matsuo, S. (1975) $15 \mathrm{~N}$ Abundance in Nitrogen of Naturally Occurring Substances and Global Assesment of Denitrification from Isoptopic Viewpoint. Geochem. J. 9, 139-148.

Wakeham, S., Farrington, J., Gagosian, B., Lee, C., DeBaar, H., Nigrelli, G., Tripp, B., Smith, S., and Frew, N. (1980) Organic Matter Fluxes from Sediment Traps in the Equatorial Atlantic 0cean. Nature 286, 798-800.

Wakeham, S., Farrington, J., and Volkman, J. (1981) Fatty Acids, Wax Esters, Triglycerides, and Glyceryl Esters Associated with Particles Collected in Sediment Traps in the Peru Upwelling. WHOI Contribution No.5057, Woods Hole Oceanographic Institution, Woods Hole, $33 \mathrm{pp}$.

Ward, B., 01 son, R., and Perry, M. (1982) Microbial Nitrification Rates in the Primary Nitrite Maximum off Southern California. Deep-Sea Res. 29, 247-255.

Watson, S. (1965) Characteristics of a Marine Nitrifying Bacterium, Nitrosocystis oceanus sp. novum. Limno1. Oceanogr. (Supp 1.) 10, R274-R289.

Watson, S. (1971) Taxonomic Considerations of the Family Nitrobacteraceae Buchanan. Inter. J. System. Bacteriol. 21, 254-270. 
Watson, S. (1978) Role of Bacteria in an Upwelling Ecosystem. In: Upwelling Ecosystems (R. Boja and M. Tomczak, eds.). Springer-Verlag, New York, pp. 139-154.

W1 otzka, F. (1972) Chapter 7.B. Nitrogen: Isotopes in Nature. In: Handbook of Geochemistry, V.II/3. (K. Wedepohl, ed.) Springer-Verlag, New York, pp. T-B-1 to T-0-3.

Whitledge, T. and Packard, T. (1971) Nutrient Excretion by Anchovies and Zooplankton in Pacific Upwelling Regions. Investi. Pesq. 35, 243-250.

Williams, P. and Gordon, L. (1970) Carbon-13:Carbon-12 Ratios in Dissolved and Particulate Organic Matter in the Sea. Deep-Sea Res. 17, 19-27.

Wong, W. and Sackett, W. (1978) Fractionation of Stable Carbon Isotopes by Marine Plankton. Geochim. Cosmochim. Acta 42, 1809-1815.

Wyrtki, K. (1967) Circulation and Water Masses in the Eastern Equatorial Pacific Ocean. Inter. J. Ocean. Limnol. 1, 117-147.

Yeh, H. and Epstein, S. (1981) Hydrogen and Carbon Isotopes of Petroleum and Related Organic Matter. Geochim. Cosmochim. Acta 45, 753-762.

Zuta, S. and Guillén, 0. (1970) Oceanografía de las Aguas Costeras del Perú. Institute del Mar Perú Boletin 2, 1-323 (in Spanish). 


\section{APPENDIX I}

\section{Double-Tube Combustion Method}

In contrast to the analyses of sediment, the plankton and POM analyses were complicated by frequent sample loss caused by the cracking of the quartz tubes during cooling following the high-temperature combustion. In addition to the cracking, the quartz glass was observed to have been partially altered to an opaque, yellow-white brittle material. A qualitative experiment was performed to determine why the plankton and POM samples reacted with the quartz and why the sediments did not. Four quartz tubes were prepared as usual. One milligram of $\mathrm{NaCl}$ was added to the first tube, one milligram of sea salt was added to the second, $200 \mathrm{mg}$ of montmorillonite-plus-illite $(<100 \mu \mathrm{m}$ grain size and pre-equilibrated with seawater) to the third and $200 \mathrm{mg}$ of montmorillonite-plus-illte plus $1 \mathrm{mg}$ sea salt to the fourth. After combustion, the tube containing $\mathrm{NaCl}$ had the yellow-white mottling also observed on the tubes in which plankton or POM had been combusted. The tube containing sea salt was much less densely colored and the two tubes containing the clay minerals were not colored at all. It was concluded that the clay minerals reacted with the $\mathrm{Na}$ in sea salt at high temperatures to form a sodium-rich silicate. When clay minerals were not present in great abundance, as in the plankton and POM samples, the sodium reacted with the quartz tube, producing a material with a thermal expansion coefficient different from that of quartz. Attempts to add clay minerals to the POM and plankton samples to prevent the tubes from cracking were abandoned because addition of the clay raised carbon and nitrogen blanks to intolerable levels.

Another series of modifications on the "long-neck" method was made to prevent further sample loss due to reaction-tube cracking. The POM samples were sealed under vacuum in the "long-neck" reaction tubes as previously described. The sealed tubes were then loaded into a quartz tube of larger dimension (Figure A-Ia.), but similar shape. Three-and-a 
$-281-$

Figure AI -1 .

Double-Tube Glassware 
a.

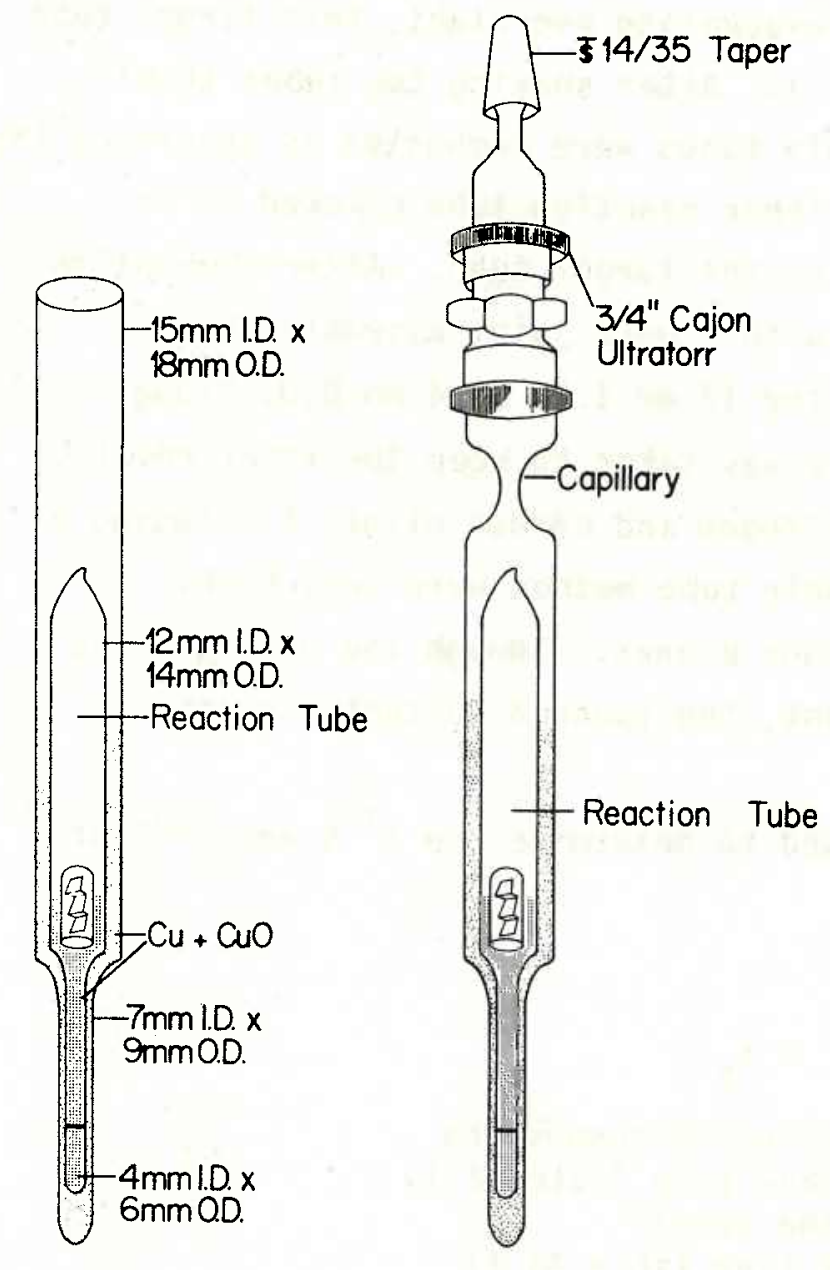

b.
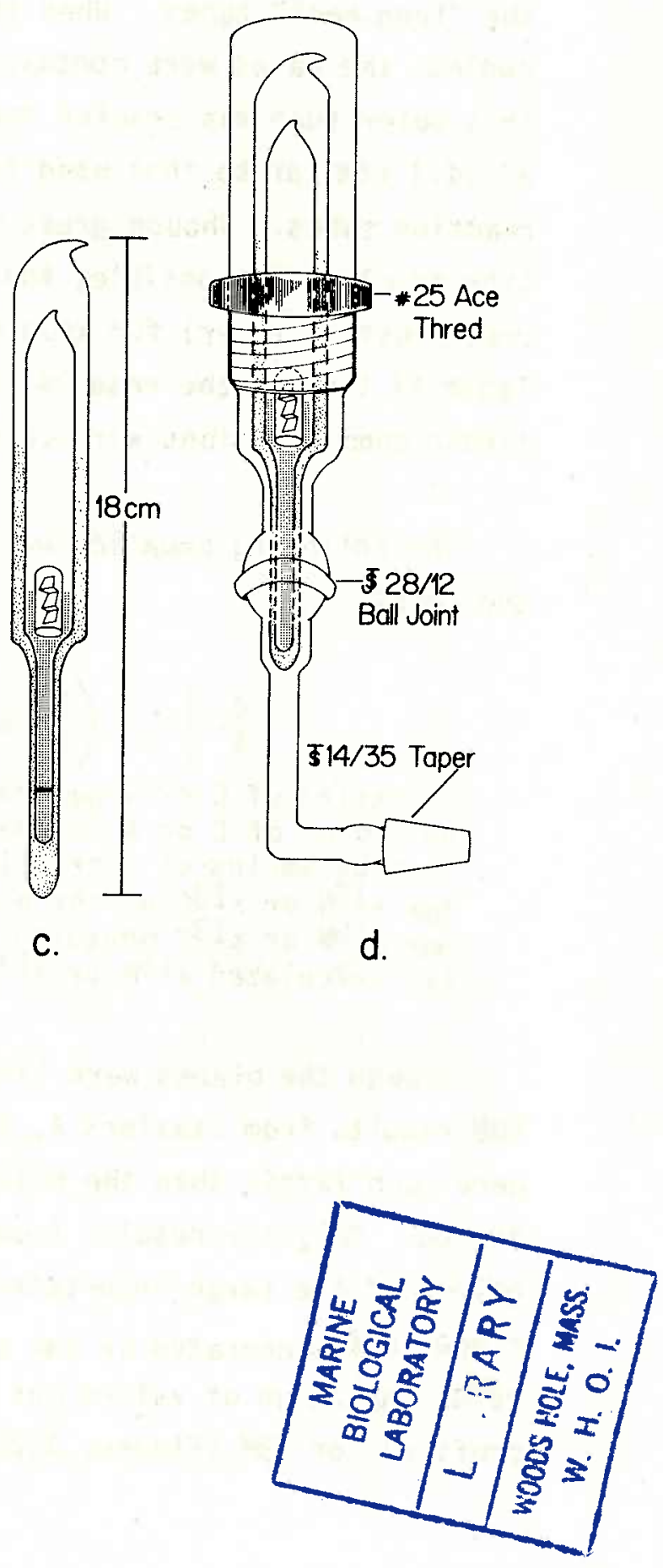
half grams of Cu0 and $1.5 \mathrm{~g}$ of $\mathrm{Cu}$ were added before formation of a capillary (Figure AI-1b.) After evacuating overnight, this larger tube was also sealed off (Figure $A I-1 C_{\text {.) }}$ ). After shaking the tubes to mix the reagents and sample, the double tubes were combusted as described for the "long-neck" tubes. When the inner reaction tube cracked as it cooled, the gases were contained by the larger tube. After combustion, this outer tube was cracked open with a ball joint assembly (Figure AI-1d.) similar to that used for the $12 \mathrm{~mm} \mathrm{I.D.} \times 14 \mathrm{~mm} \mathrm{0.D.} \mathrm{"long-neck"}$ reaction tubes. Though great care was taken to keep the inner reaction tube as clean as possible, the nitrogen and carbon blanks (including a precombusted filter) for this double tube method were very high. Table AI-1 shows the results of four blanks. Though the nitrogen and carbon concentrations were constant, the isotope content was not.

The following equation was used to determine the $\delta^{15} \mathrm{~N}$ and $\delta^{13} \mathrm{C}$ of the sample:

$$
\frac{c}{s}\left[\delta_{m}-\left(\frac{b}{c}\right) \delta_{b}\right]=\delta_{s}
$$

$C=\mu$ moles of $C$ or $N$ generated during combustion

$\mathrm{b}=$ umoles of $\mathrm{C}$ or $\mathrm{N}$ in the blank (see Table AI-1)

$\mathrm{S}=\mathrm{C}-\mathrm{b}=\mu \mathrm{moles}$ of $\mathrm{C}$ or $\mathrm{N}$ in the sample

$\delta_{b}=\delta 15 \mathrm{~N}$ or $\delta 13 \mathrm{C}$ of the blank (see Table AI-1)

$\delta_{m}=\delta 15 \mathrm{~N}$ or $\delta 13 \mathrm{C}$ measured

$\delta_{s}=$ calculated $\delta 15_{N}$ or $\delta 13 \mathrm{C}$ of the sample

Though the blanks were large, they did not significantly affect the POM results from Stations A, B, SEAREX, or Gulf of Maine, as the samples were much larger than the blanks or were analyzed by the "long-neck" tube method. Only the results from Station $C$ were severely compromised. The effect of the large uncertainty in $\delta_{b}$ was determined by calculating the range in $\delta$ generated by one standard deviation in $\delta \mathrm{b}$. The resulting range of values has been plotted in the $\delta^{15_{N}}$ and $\delta^{13} \mathrm{C}$ profiles for POM (Figures $3-20,3-22,3-26,3-30$, and 4-5). 
Table AI-1.

Double-Tube Filter Blanks

\begin{tabular}{|c|c|c|c|c|}
\hline umoles $N$ & umoles C & $C / N$ & $\begin{array}{l}\delta^{15} N \\
(0 / 00)\end{array}$ & $\begin{array}{l}\delta^{13 C} \\
(0 / 00)\end{array}$ \\
\hline $\begin{array}{l}4.6 \\
3.8 \\
4.1 \\
4.7\end{array}$ & $\begin{array}{l}12.9 \\
12.0 \\
14.1 \\
13.9\end{array}$ & $\begin{array}{l}2.8 \\
3.1 \\
3.4 \\
3.0\end{array}$ & $\begin{array}{l}2.7 \\
7.3 \\
8.8 \\
1.1\end{array}$ & $\begin{array}{l}-23.2 \\
-18.0 \\
-22.6 \\
-24.8\end{array}$ \\
\hline $\begin{array}{r}\text { Average: } 4.3 \\
1 \text { S.D.: } 0.4\end{array}$ & $\begin{array}{r}13.2 \\
0.9\end{array}$ & $\begin{array}{l}3.1 \\
0.2\end{array}$ & $\begin{array}{l}5.0 \\
3.1\end{array}$ & $\begin{array}{r}-22.1 \\
2.5\end{array}$ \\
\hline
\end{tabular}




\section{APPENDIX II}

\section{Distilled-Water Rinsing Experiment}

Since sea salt was found to cause cracking of the reaction tubes, its removal from the $\mathrm{plankton}$ and POM samples was considered (see Appendix I for a discussion of this phenomenon). A short experiment was done to determine if rinsing the POM samples with distilled water altered either the organic-matter concentration or the $\delta 15_{\mathrm{N}}$ and $\delta 13 \mathrm{C}$ values. Filters containing POM were cut in half. One half was carefully flooded with distilled water and sucked dry on a Millipore filtration apparatus seven times. A precombusted filter was used as a filter support and was al so analyzed for carbon and nitrogen. Carbon and nitrogen contents were determined by a Perkin-Elmer CHN analyzer on a half of the unrinsed filter half. The carbon and nitrogen contents, $\delta 15 \mathrm{~N}$ and $\delta 13 \mathrm{C}$ of one half of the rinsed filter half and of the entire filter used as a support were determined by combustion in a closed quartz tube as described in Chapter II. For the purposes of comparison, the one half of the remaining rinsed filter half was combusted in the $\mathrm{CHN}$ analyzer. The results are shown in Table AII-1, along with the results of closed quartz tube combustion of a very small portion (1/8) of a duplicate filter collected at the same station and depth as the filter used for the rinsing experiment.

Significant differences in organic matter and isotopic content were observed between the rinsed and unrinsed filter quarters. Heterogeneous distribution of POM on the filters may have been the cause of these differences though good agreement was found between analyses of several sections of other filters containing POM (Gulf of Maine, 25 and $40 \mathrm{~m}$ (Figure 4-5), and Station B, $20 \mathrm{~m}$ (Figure 3-26)). The higher $\delta 15 \mathrm{~N}$ of the rinsed filters suggests that $15 \mathrm{~N}$-depleted POM was solubilized. It appears that a significant fraction of the solubilized nitrogen was retained (adsorbed) by the filter support. The very $10 \mathrm{w} \delta 15 \mathrm{~N}$ of the filter support further suggests that $14 \mathrm{~N}$ was preferentially removed 
Table AII -1.

Distilled-Water Rinsing Experiment

$\begin{array}{llllc}{[\mathrm{PON}]} & {[\mathrm{POC}]} & \mathrm{C} / \mathrm{N} & \delta^{15} \mathrm{~N} \delta{ }^{13} \mathrm{C} \\ (\mu \mathrm{g} / 1) & (\mu \mathrm{g} / 1) & & (\% / 00)(\% / 00)\end{array}$

\begin{tabular}{|c|c|c|c|c|c|c|}
\hline & Duplicate Filter & 49.7 & 178.0 & 4.2 & 3.8 & -20.1 \\
\hline Station A & CHN Analysis-unrinsed & 21.3 & 168.6 & 6.8 & -- & -- \\
\hline \multirow[t]{4}{*}{$45 \mathrm{~m}$} & CHN Analysis-rinsed & 17.5 & 152.6 & 7.5 & -- & -- \\
\hline & Quartz Tube Comb.-rinsed & 24.9 & 163.0 & 7.6 & 9.0 & -22.1 \\
\hline & Filter Support & $0.54^{\star}$ & $0.4 * *$ & 3.1 & -4.1 & -25.1 \\
\hline & Duplicate Filter & 69.9 & 212.7 & 3.6 & 8.8 & -20.5 \\
\hline Station A & CHN Analysis-unrinsed & 20.1 & 146.4 & 6.2 & -- & -- \\
\hline \multirow[t]{4}{*}{$35 \mathrm{~m}$} & CHN Analysis-rinsed & 18.7 & 165.5 & 10.3 & -- & -- \\
\hline & Quartz Tube Comb.-rinsed & 23.6 & 156.0 & 7.7 & 9.1 & -21.9 \\
\hline & Filter Support & $0.47^{\star}$ & $0.4^{\star \star}$ & 3.2 & -4.1 & -25.1 \\
\hline & Duplicate Filter & 13.8 & 94.2 & 4.2 & 3.8 & -20.1 \\
\hline Station A & CHN Analysis-unrinsed & 17.1 & 105.7 & 7.2 & -- & -- \\
\hline $25 \mathrm{~m}$ & CHN Analysis-rinsed & 12.5 & 94.0 & 8.8 & -- & -- \\
\hline & Quartz Tube Comb.-rinsed & - & -- & - & -- & -- \\
\hline & Filter Support & $0.54^{\star}$ & $0.4^{\star \star}$ & 3.1 & -1.3 & -22.5 \\
\hline
\end{tabular}

* $\frac{\mu \text { moles } N \text { on filter support }}{\text { umoles } N \text { on rinsed filter }}$

${ }^{\star \star} \frac{\mu \text { moles } C \text { on fil ter support }}{\mu \text { moles } C \text { on rinsed filter }}$ 
from the top filter during rinsing. The 1 arger $\mathrm{C} / \mathrm{N}$ ratio of the rinsed filters, with respect to the unrinsed POM, indicates that nitrogen was preferentially leached. The low $\mathrm{C} / \mathrm{N}$ of the filter support further indicates that the nitrogen removed from the top filter was retained by the lower filter.

In addition, the quartz reaction tubes used for combustion of the rinsed filters had the yellow-white mottling characteristic of high salt and low clay-mineral content in the samples (see Appendix I). One of the samples (Station $A, 25 \mathrm{~m}$, rinsed) was lost as the reaction tube cracked during cooling. Thus, far more extensive rinsing was required to remove the amount of salt necessary to prevent sample loss. The higher $\delta^{15} \mathrm{~N}$ values of the rinsed filters suggest that this cannot be done without greatly altering the $i$ sotopic content of the sample. 


\section{BIOGRAPHICAL NOTE}

The author was born in Brooklyn, New York on February 21, 1956. She received a B.A. with General and Departmental Honors in chemistry from Douglass College, Rutgers University in June of 1977 and a Ph.D. in Chemical Oceanography from the Massachusetts Institute of Technology/Woods Hole Oceanographic Insitution Joint Program in Oceanography in January of 1983. She is presently an assistant professor in the Marine Science Department at Coastal Carolina College, University of South Carolina.

Susan has two parents, Sol and Lennie, one brother, Don, and two kitties, Aleca and a cat yet unnamed.

\section{Publications:}

Libes, S. Nitrogen Isotope Chemistry of Particulates. EOS 63 (1982) 90. 